Geohydrologic Data Collected from Shallow Neutron-

Access Boreholes and Resultant-Preliminary

Geohydrologic Evaluations, Yucca Mountain Area,

Nye County, Nevada

by Daniel O. Blout, Raytheon Services, Nevada,

Dale P. Hammermeister, Carole L. Loskot, and Michael P. Chornack, U.S. Geological Survey

U.S. GEOLOGICAL SURVEY

Open-File Report 92-657

Prepared in cooperation with the NEVADA OPERATIONS OFFICE U.S. DEPARTMENT OF ENERGY

(Interagency Agreement DE-Al08-92NV10874) 


\section{U.S. DEPARTMENT OF THE INTERIOR \\ BRUCE BABBITT, Secretary \\ U.S. GEOLOGICAL SURVEY \\ Robert M. Hirsch, Acting Director}

The use of trade, product, industry, or firm names is for descriptive purposes only and does not imply endorsement by the U.S. Government.

For additional information write to:

Chief, Hydrologic Investigations Program

Yucca Mountain Project Branch

U.S. Geological Survey

Box 25046, MS 421

Denver Federal Center

Denver, CO 80225
Copies of this report can be purchased from:

U.S. Geological Survey

Earth Science Information Center

Open-File Reports Section

Box 25286, MS 517

Denver Federal Center

Denver, CO 80225 


\section{CONTENTS}

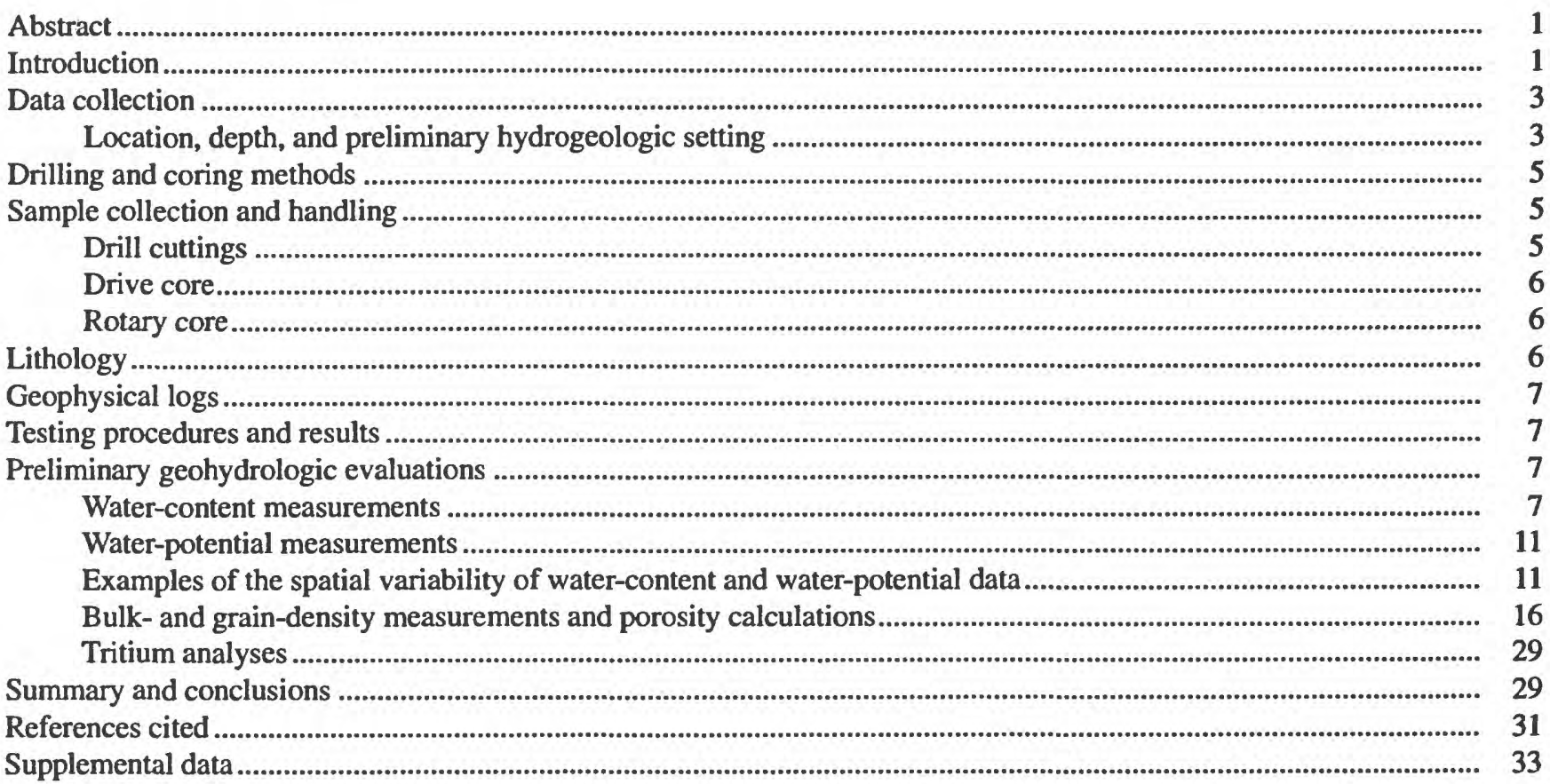

\section{FIGURES}

1. Map showing Yucca Mountain study area and vicinity

2. Map showing Yucca Mountain location of drilled and proposed boreholes.

3. Water-content profiles for different particle-size fractions of drill-cutting samples from two boreholes..

4. Water-content profiles for different particle-size fractions of drive-core samples from two boreholes located in different topographic positions in alluvium/colluvium, UZN \#4 is located on a terrace, and $\mathrm{UZN} \# 6$ is in an active drainage channel

5. Water-content profiles for boreholes UZ-N89 and UZ-N90 located approximately $1 \mathrm{~m}$ apart in a channel in alluvium/colluvium.

6. Water-potential profiles for boreholes UZ-N89 and UZ-N90 located approximately $1 \mathrm{~m}$ apart in a channel in alluvium/colluvium.

7. Water-content for boreholes UZ-N84 and UZ-N87 located approximately $1 \mathrm{~m}$ apart on a terrace where alluvium/colluvium overlies welded tuff

8. Water-potential profiles for boreholes UZ-N84 and UZ-N87 located approximately $1 \mathrm{~m}$ apart on a terrace where alluvium/colluvium overlies welded tuff .

9. Water-content profiles for boreholes UZ-N83 and UZ-N86 located approximately $30 \mathrm{~m}$ apart in welded tuff exposed in a channel

10. Water-potential profiles for boreholes UZ-N83 and UZ-N86 located approximately $30 \mathrm{~m}$ apart in welded tuff exposed in a channel

11. Water-content profiles for boreholes UZ-N75 and UZ-N76 located approximately $10 \mathrm{~m}$ apart in moderately welded tuff near the crest of Yucca Mountain ...

12. Water-potential profiles for boreholes UZ-N75 and UZ-N76 located approximately $10 \mathrm{~m}$ apart in moderately welded tuff near the crest of Yucca Mountain .

13. Water-content profiles for boreholes UZN \#28 and UZN \#97 located approximately $1 \mathrm{~m}$ apart in a braided channel area of alluvium/colluvium.

14. Water-potential profiles for boreholes UZN \#28 and UZN \#97 located approximately $1 \mathrm{~m}$ apart in a braided channel area of alluvium/colluvium.

15. Water-content profiles for boreholes UZN \#13, located in an active drainage channel, and UZN \#14, located on a terrace, both boreholes in alluvium/colluvium. 
16. Water-potential profiles for boreholes UZN \#13, located in an active drainage channel, and UZN \#14 located on a terrace, both boreholes in alluvium/colluvium.

17. Water-content profile for borehole UZ-N86 located on an exposed bedrock channel compared to a profile from borehole UZ-N88 located on exposed bedrock on an adjacent hill slope.

18. Water-potential profile for borehole UZ-N86 located on an exposed bedrock channel compared to a profile from borehole UZ-N88 located on exposed bedrock on an adjacent hill slope.

19. Water-content profile for borehole UZ-N72 located on an exposed bedrock channel compared to a profile from borehole UZ-N74 located on exposed bedrock on an adjacent hill slope.

20. Water-potential profile for borehole UZ-N72 located on an exposed bedrock channel compared to a profile from borehole UZ-N74 located on exposed bedrock on an adjacent hill slope.

21. Tritium profiles for selected neutron-access boreholes.

\section{TABLES}

1. Location, depth, and geohydrologic setting of neutron-access boreholes

2. Estimates of the relative area and selected properties of the preliminary hydrogeologic-surficial units.................. 39

3. Lithologic logs of the neutron-access boreholes at Yucca Mountain.......................................................................... 40

4. Results of laboratory analyses of hydrologic characteristics of drill cuttings from neutron-access boreholes ........ 66

5. Results of laboratory analyses of hydrologic characteristics of core samples from selected neutron-access boreholes

6. Description of central tendency and dispersion of gravimetric water-content data from coarse drill cuttings as a function of lithology and degree of welding

7. Description of central tendency and dispersion of gravimetric water-content data from composite core samples as a function of lithology and degree of welding

8. Summary of linear-regression analyses for water-content and water-potential values of composite core samples versus coarse drill cuttings for rock units that have different degrees of welding..

9. Description of central tendency and dispersion of water-content data of coarse drill cuttings from moderately and densely welded lithologic units of the Tiva Canyon Member

10. Description of central tendency and dispersion of water-content data of composite core samples from moderately and densely welded lithologic units of the Tiva Canyon Member.

11. Description of central tendency and dispersion of water-potential data from coarse drill cuttings as a function of lithology and degree of welding..

12. Description of central tendency and dispersion of water-potential data from composite core samples as a function of lithology and degree of welding

13. Description of central tendency and dispersion of water-potential data of drill cuttings from moderately and densely welded lithologic units of the Tiva Canyon Member ....

14. Description of central tendency and dispersion of water-potential data of composite core samples from moderately and densely welded lithologic units of the Tiva Canyon Member.

15. Results of laboratory analyses of physical properties of rotary-core samples from selected neutron-access boreholes

16. Description of central tendency and dispersion of density and porosity data as a function of lithology and degree of welding

17. Results of laboratory analyses of tritium in drive-core samples from selected neutron-access boreholes 


\section{CONVERSION FACTORS AND VERTICAL DATUM}

\begin{tabular}{rll}
\hline Multiply & By & To obtain \\
\hline gram $(\mathrm{g})$ & & \\
gram per cubic centimeter $\left(\mathrm{g} / \mathrm{cm}^{3}\right)$ & 0.03527 & ounce $(\mathrm{oz})$ \\
kilometer $(\mathrm{km})$ & 0.03613 & pound per cubic inch $\left(\mathrm{lb} / \mathrm{in}^{3}\right)$ \\
kilopascal $(\mathrm{kPa})$ & 0.6214 & mile $(\mathrm{mi})$ \\
kilopascal $(\mathrm{kPa})$ & 0.1450 & 14.5 pound per square inch $\left(\mathrm{lb} / \mathrm{in}^{2}\right)$ \\
liter $(\mathrm{l})$ & 0.01 & bar \\
meter $(\mathrm{m})$ & 3.2641 & gallon (gal) \\
millimeter $(\mathrm{mm})$ & 0.03937 & foot $(\mathrm{ft})$ \\
& & inch (in.) \\
\hline
\end{tabular}

Degree Fahrenheit $\left({ }^{\circ} \mathrm{F}\right)$ may be converted to degree Celsius $\left({ }^{\circ} \mathrm{C}\right)$ by using the following equation:

${ }^{\circ} \mathrm{C}=5 / 9 \cdot\left({ }^{\circ} \mathrm{F}-32\right)$.

Sea level: In this report "sea level" refers to the National Geodetic Vertical Datum of 1929 (NGVD of 1929)--a geodetic datum derived from a general adjustment of the first-order level nets of both the United States and Canada, formerly called Sea Level Datum of 1929. 


\title{
Geohydrologic Data Collected from Shallow Neutron-Access Boreholes and Resultant-Preliminary Geohydrologic Evaluations, Yucca Mountain Area, Nye County, Nevada
}

\author{
ByDaniel O. Blout, Dale P. Hammermeister, Carole L. Loskot, and Michael P. Chornack
}

\section{Abstract}

In cooperation with the U.S. Department of Energy, 74 neutron-access boreholes were drilled in and near the southwestern part of the Nevada Test Site, Nye County, Nevada. Drilling, coring, sample collection and handling, and lithologic and preliminary geohydrologic data are presented in this report.

The boreholes were drilled in a combination of alluvium/colluvium, ash-flow tuff, ash-fall tuff, or bedded tuff to depths of 4.6 to 36.6 meters. Air was used as a drilling medium to minimize disturbance of the water content and water potential of drill cuttings, core, and formation rock. Drill cuttings were collected at approximately 0.6-meter intervals. Core was taken at selected intervals from the alluvium/colluvium using drive-coring methods and from tuff using rotary-coring methods. Nonwelded and bedded tuffs were continuously cored using rotary-coring methods.

Gravimetric water-content and waterpotential values of core generally were greater than those of corresponding drill cuttings. Gravimetric water-content, porosity, and water-potential values of samples generally decreased, and bulk density values increased, as the degree of welding increased. Grain-density values remained fairly constant with changes in the degree of welding.

A high degree of spatial variability in watercontent and water-potential profiles was noted in closely spaced boreholes that penetrate similar lithologic subunits and was also noted in adjacent boreholes located in different topographic positions. Variability within a thick lithologic unit usually was small.

\section{INTRODUCTION}

The U.S. Geological Survey has been conducting studies at Yucca Mountain, Nevada (fig. 1), to evaluate the hydrologic and geologic suitability of this potential site for storing high-level radioactive wastes in an underground mined repository (Waddell, 1982; Roseboom, 1983; Montazer and Wilson, 1984; Squires and Young, 1984; Waddell and others, 1984). These studies are a part of the Yucca Mountain Project, formerly the Nevada Nuclear Waste Storage Investigations (NNWSI), conducted in cooperation with the U.S. Department of Energy, Nevada Operations Office, as part of Interagency Agreement DE-AI08-78ET44802. Test drilling has been a principal method of geohydrologic investigation (Bentley and others, 1983; Thordarson and others, 1984). Work on the neutronaccess boreholes was performed in accordance with the Yucca Mountain Project Quality Assurance Program.

Approximately 98 neutron-access boreholes have been planned to monitor natural infiltration in, and to collect matrix hydrologic-property data from, the surficial materials covering Yucca Mountain. Seventy-four of these boreholes were completed as of February 1986. The monitoring of natural infiltration with these boreholes is one of several shallow unsaturated-zone activities on Yucca Mountain designed to define upper flux-boundary conditions during both present-day and simulated wetter-climatic conditions. These flux-boundary conditions are necessary to model flow through the thick unsaturated zone beneath Yucca Mountain.

A majority of the 98 drilled and proposed neutron-access boreholes are located outside the boundaries of the Nevada Test Site (NTS). This land is administered by the Bureau of Land Management or the U.S. Air Force but has been designated as the Nevada Nuclear Waste Site Investigation permit area. For boreholes located off the NTS, the designation is USW UZ-Nxx; for boreholes located on the NTS, the designation is UE-25 UZN \#xx, where $\mathrm{xx}$ is the borehole number and where 25 is the NTS area number. 

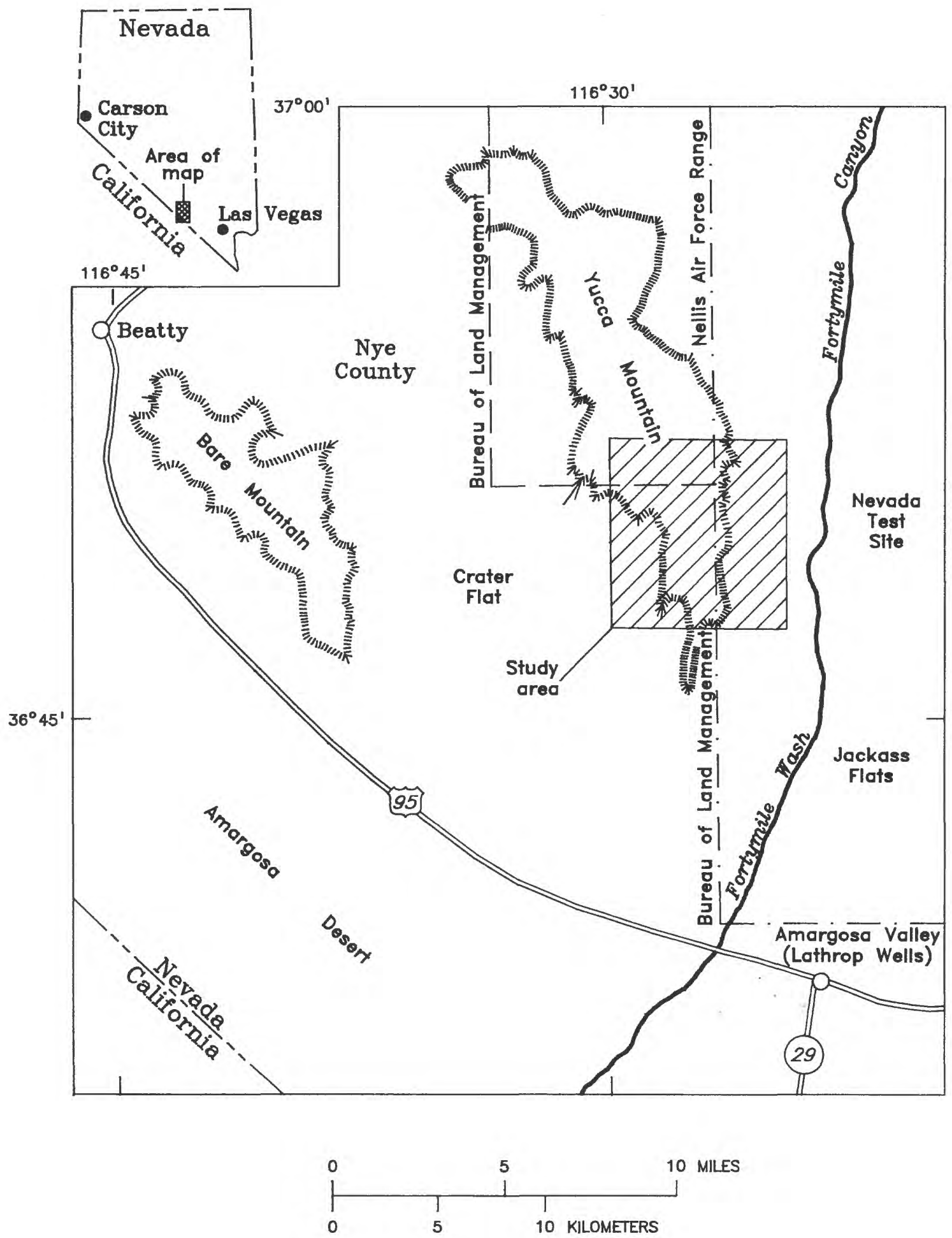

Figure 1.--Yucca Mountain study area and vicinity. 
Hereafter, these boreholes will be referred to without the USW or UE-25 prefix in this report (in the text and figures) but are identified in table 1 in the "Supplemental Data" section at the back of the report.

This report presents drilling, coring, geologic, and preliminary hydrologic data from the 74 completed neutron-access boreholes. Methods for drilling, coring, collecting, handling, and testing of geologic samples have been described elsewhere (Hammermeister and others, 1986) and will be mentioned only briefly in this report. Lithologic information, water-content and water-potential data will be described in detail. Density values and tritium concentrations from a few selected boreholes will also be presented.

Hydrologic measurements made on geologic samples collected during drilling and coring have provided an initial determination of the vertical distribution of water-content and water-potential data in surficial materials. Water-content profiles in the formation rock adjacent to the boreholes have been monitored periodically by neutron-logging methods. The changes in the water-content profiles have been used to characterize water movement in the immediate vicinity of the boreholes since the time of drilling.

\section{DATA COLLECTION}

\section{Location, Depth, and Preliminary Hydrogeologic Setting}

The 74 neutron-access boreholes are located on Yucca Mountain near the southwestern part of the Nevada Test Site, Nye County, Nevada. Efforts have been made to locate the boreholes so that they encompass the range in hydrologic properties and conditions expected to be encountered in the surficial materials covering Yucca Mountain. Preliminary hydrogeologic-surficial units were identified from Scott and Bonk, 1984, and have been used as a guide for locating the neutron-access boreholes. The locations of the 74 completed boreholes and 24 additional proposed boreholes are shown in figure 2 . The neutron-access borehole number, location, elevation, borehole depth, tuff/alluvium contact, preliminary hydrogeologicsurficial unit, and topographic position for each borehole (drilled and proposed) are summarized in table 1 in the "Supplemental Data" section at the back of the report.

Yucca Mountain initially was divided into two hydrogeologic-surficial units for the purpose of locating neutron-access boreholes: (1) An alluvium/ colluvium unit in canyon bottoms, and (2) an uplandbedrock unit usually covered with a thin layer of unconsolidated material. Ideally, each hydrogeologicsurficial unit should be characterized by a set of substantially different infiltration properties. However, information from Yucca Mountain such as infiltration data, soil maps, or unconsolidated geologic-surficial material maps were not available to enable characterization of additional, more detailed, hydrogeologicsurficial units prior to drilling these boreholes. As a result, the first 30 neutron-access boreholes were located and drilled using this two-unit classification system.

Drilling and initial neutron-moisture logging of the first group of boreholes completed in the uplandbedrock unit indicated noticeably different infiltration characteristics, which appeared to be qualitatively related to observed fracture-densities. Because the consolidated surficial units defined by Scott and Bonk (1984) also indicated differences in fracture-densities (R.A. Spengler, U.S. Geological Survey, oral commun., 1986), it was decided to define hydrogeologic-surficial units in upland areas as equivalent to the consolidated geologic subunits defined by Scott and Bonk (1984). These preliminary hydrogeologic-surficial units, and a qualitative estimate of their fracturedensity values, are summarized in table 2 in the "Supplemental Data" section at the back of the report, and have been used to locate all subsequent neutronaccess boreholes.

Neutron-access boreholes were located in alluvium/colluvium in canyon bottoms along lines parallel, perpendicular, or both, to the main axes of those canyons. Boreholes were located perpendicular to the canyon axis to examine how natural-infiltration processes were affected by the thickness of unconsolidated deposits and the position of boreholes in relation to canyon walls and to the center of the most recently formed channels. Boreholes were located parallel to the main canyon axis to study the effects of increased drainage area on infiltration. All boreholes located in alluvial/colluvial deposits were drilled through the entire thickness of these deposits and at least $1 \mathrm{~m}$ into the underlying consolidated bedrock. These boreholes generally were drilled to depths greater than $10 \mathrm{~m}$.

To determine the effects of slope and soil thickness on natural infiltration in upland areas adjacent to and above canyon bottoms, neutron-access boreholes were located in different topographic positions within the hydrogeologic surficial units. Most neutron-access boreholes in the upland hydrogeologic-surficial units generally were drilled to a depth of approximately $15 \mathrm{~m}$. 


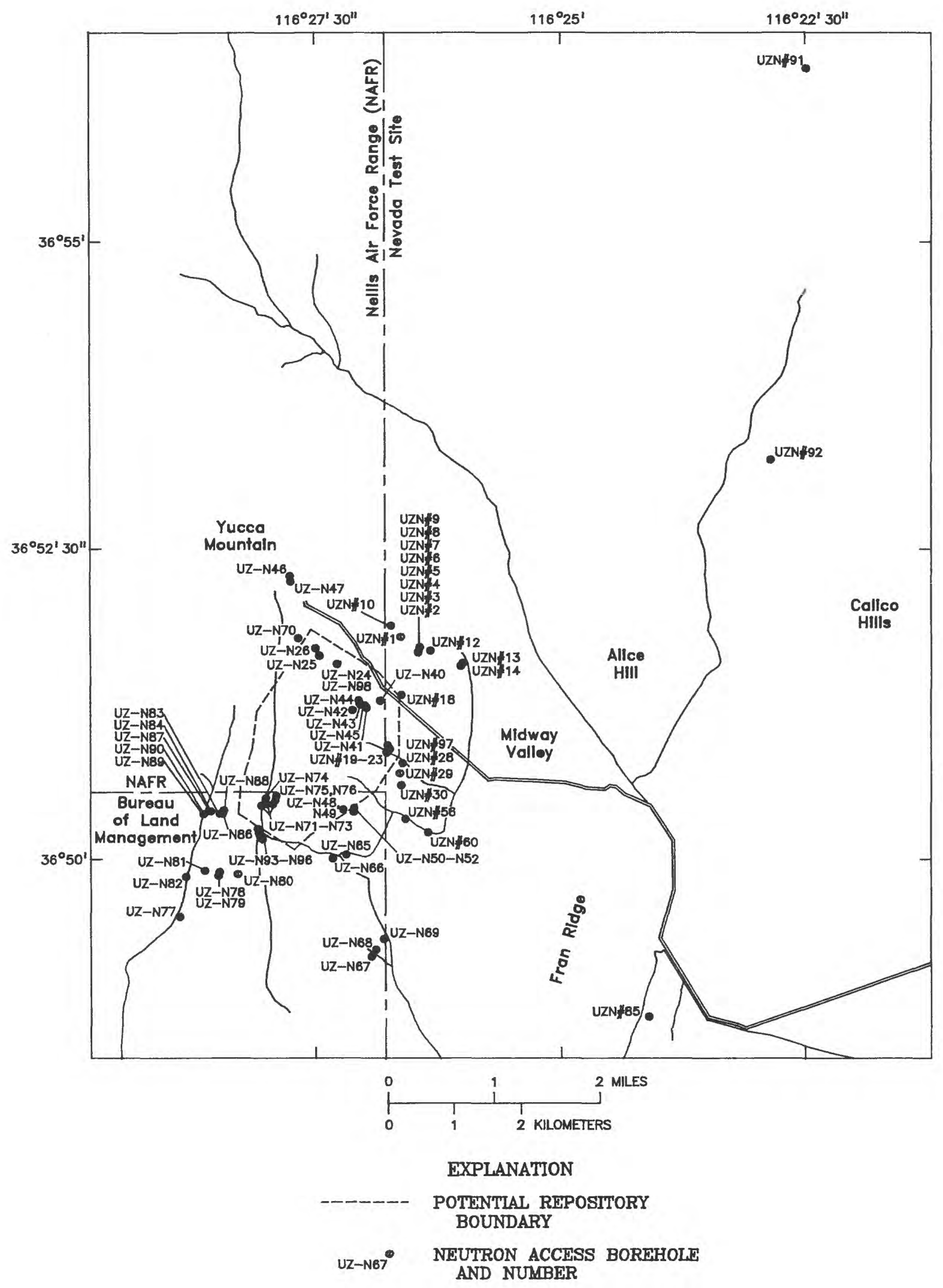

Figure 2.--Yucca Mountain and vicinity showing location of drilled neutronaccess boreholes. 


\section{DRILLING AND CORING METHODS}

Neutron-access boreholes were drilled using the ODEX 115 drilling system with air as the drilling fluid. Core samples were obtained from selected neutronaccess boreholes by drive-core methods in unconsolidated alluvium/colluvium and by rotary-core methods in tuffs. These drilling and coring methods and equipment have been described in detail by Hammermeister and others (1986). These authors also have presented evidence that these methods minimally disturb the insitu water content of the formation as well as that of the geologic samples (drill cuttings and core).

The ODEX 115 system of drilling uses a downhole percussion hammer to drill and ream at the bottom of the casing. A pilot bit, in conjunction with an eccentric reamer, drills a hole slightly larger than the outside diameter of the casing. The diameter of the resulting hole is approximately $152 \mathrm{~mm}$, the outside diameter of the casing is $140 \mathrm{~mm}$, and the casing wall is approximately $13 \mathrm{~mm}$ thick. The percussion hammer also impacts on the casing through a shoe attached to the bottom joint of the casing. Thus, the casing is advanced downward as the borehole is drilled deeper. Drill cuttings are returned to the surface through the inside of the casing, thereby minimizing disturbance of the formation by drilling fluids.

Coring was done to collect intact geologic samples at selected intervals in designated neutron-access boreholes. The ODEX 115 casing was advanced downward until the desired coring depth was reached. Drive-core samples were obtained by driving a heavyduty $101.6 \mathrm{~mm}$ inside-diameter by $0.61-\mathrm{m}$ long solidtube sampler attached directly to a percussion hammer approximately $0.61 \mathrm{~m}$ into alluvium/colluvium deposits. These unconsolidated core samples usually were collected at $1.52-\mathrm{m}$ intervals. Even though this drivecoring method does not greatly disturb the gravimetric water content of samples, it has been shown to alter the porosity and related properties of drive-core samples compared to in-situ properties (Hammermeister and others, 1986).

Rotary coring was done with a $1.52 \mathrm{~m}$ tripletube, HWD4-size wireline core barrel modified by Norton Christensen, Inc. for air coring. The resulting core was approximately $63.5 \mathrm{~mm}$ in diameter. Nonwelded and bedded tuffs were cored continuously using a stagger-tooth carbide-tipped bit. Welded tuffs were cored for short intervals (usually less than $0.61 \mathrm{~m}$ ) with diamond-set face-discharge bits. The welded tuffs are devitrified, and the rock is hard, brittle, and fractured, which in part caused shorter core runs.

After being cored to the desired depth interval, the borehole was enlarged (reamed), and the casing was advanced to the bottom of the borehole. The drilling, coring, reaming, and casing sequence was repeated until the total depth of the borehole was reached. Drill cuttings were collected at regular intervals from nearly all neutron-access boreholes; drive core and rotary core were collected from selected intervals of unconsolidated alluvium/colluvium and consolidated tuffaceous rock. Complete records, including depth, cored interval, sample interval, quantity of core recovered, and hydrologic test assignment, can be found on file at the U.S. Geological Survey, Hydrologic Research Facility, Nevada Test Site. A detailed history of drilling and coring of the boreholes is contained in a report (Fenix \& Scisson, 1987).

\section{SAMPLE COLLECTION AND HANDLING}

During sample collection and handling, every effort was made to minimize the opportunity for water to evaporate from the samples from the time these samples were removed from the borehole to the time watercontent or water-potential measurements could be made. Quality assurance procedures were followed (Colleen McBride, USGS, written commun., 1985) to meet these requirements. Because measurements of water-potential were not made on samples immediately after collection, the samples were stored in sealed, waxed containers at room temperature until such measurements could be made. Furthermore, samples collected onsite were divided into subsamples in a humidified glove box which minimized evaporation of water from these samples during handling. A detailed description of sample collection and handling methods is given in Hammermeister and others (1986).

The first three neutron-access boreholes drilled were UZN \#18, UZN \#20, and UZ-N70. These holes were drilled to test the ODEX drilling system. During drilling, cuttings were collected for lithologic description. There were no samples collected from these holes for hydrologic measurements.

\section{Drill Cuttings}

Drill cuttings were diverted from the borehole through a flexible hose to a dry cyclone separator. As drilling progressed, two drill-cutting samples were collected from the bottom of the cyclone separator through a gate valve that was opened by a hand lever, usually after an interval of $0.61 \mathrm{~m}$ had been drilled. One sample was collected in a paper carton for the purpose of a lithologic description of each drilled interval. These samples are archived at the Sample Management Facility at the NTS. A second sample was collected in an 
airtight glass jar for laboratory measurements of water content and water potential. The jars were labeled, taped, waxed, and stored at approximately 20 to $25^{\circ} \mathrm{C}$ until measurements could be made.

Initially, during drilling of the first few neutronaccess boreholes, drill-cutting samples designated for water-content and water-potential measurements were divided into composite, coarse, and fine particle-size fractions. The samples were sieved through a screen with 5-mm openings to separate the cuttings into coarse- and fine-size particles. Unsieved cuttings were designated as composite samples. These measurements were designed to determine the distribution of water-content and water-potential values among particle-size fractions of cuttings and to determine which fraction yielded water-content and water-potential values most representative of the formation rock. In later boreholes, generally only coarse samples were collected.

\section{Drive Core}

Solid-tube drive-core samples were immediately brought to the onsite-laboratory trailer and placed in a humidified glove box once they were collected from the borehole. The solid-tube drive-core samplers were fitted with six 100 -mm outside-diameter brass liners to contain the unconsolidated geologic samples after removal from the tube samplers. These brass liners were divided into two $152-\mathrm{mm}$ and four 76- $\mathrm{mm}$ lengths to facilitate the division of the drive core into subsamples for different hydrologic-property measurements. Initially, attempts were made to manually push the brass liners out of solid tube samplers. This proved impossible without disturbing the core. A power coreextrusion device then was designed and built to remove the brass liners. However, drive core was taken from a number of holes (including UZN \#4, UZN \#6, UZN \#8, UZN \#12, UZN \#13, UZN \#14, UZN \#60, and

UZ-N69) before the extrusion device was built. Drivecore samples from these boreholes were not further subdivided into different length intervals because of the disturbance and mixing that occurred during the removal of the liners from the solid-tube samples.

Different segments of the drive core were designated for the measurement of the following properties and conditions: tritium concentrations, gravimetric water-content and water-potential values, permeability and matric-potential values, and density and volumetric water-content values. In some instances, segments selected for gravimetric water-content and waterpotential measurements were sieved into coarse and fine particle-size fractions to determine the distribution of values with particle size. Gravimetric water-content measurements were done at the onsite laboratory; samples for water-potential measurements were placed in glass jars and capped, taped, waxed, labeled, and transported to the U.S. Geological Survey hydrologic laboratory for testing. All samples in liner segments were capped, taped, waxed, labeled, and stored at approximately 20 and $25^{\circ} \mathrm{C}$ until the specified test could be performed.

\section{Rotary Core}

After each core run was completed, the split inner tube was removed from the core barrel at the drill site and immediately taken to the onsite laboratory and placed in a humidified glove box for processing. The natural fractures of the core were described, and a preliminary lithologic description was made. Generally, this intact, $1.52-\mathrm{m}$ piece of core was recovered from nonwelded and bedded tuffs. Two 76-mm segments of core were split from the upper and lower parts of the available core for water-potential and gravimetric water-content measurements. The samples for waterpotential measurements were broken into rubble and stored in airtight glass jars until measurements could be made. The jars were labeled, taped, waxed, and stored at approximately 20 to $25^{\circ} \mathrm{C}$ until measurements could be made. Two 76-mm segments and two $152-\mathrm{mm} \mathrm{seg-}$ ments were split from the bottom and midsections of the available core. The smaller segments were designated for matric-potential measurements, and the larger segments were designated for permeability-related measurements. These samples were placed in split polyvinyl chloride liners and capped, taped, labeled, waxed, and stored at approximately 20 to $25^{\circ} \mathrm{C}$ until designated laboratory testing could be done.

\section{LITHOLOGY}

The lithologic descriptions of the neutron-access boreholes were made from drill cuttings, drive core, and rotary-core samples. The lithologies penetrated by the boreholes include bouldery alluvial/colluvial deposits, poorly consolidated bedded tuffs, nonwelded tuffs, and fractured welded tuffs. The lithologic logs of the boreholes are presented in table 3 in the "Supplemental Data" section at the back of the report. The alluvial/colluvial material derived from these tuffs are of Quaternary/Tertiary age. Four of the boreholes (UZN \#13, UZN \#14, UZ-N68, and UZ-N69) were drilled into nonwelded to partially welded sections of 
the Rainier Mesa Member of the Timber Mountain Tuff, which is of Tertiary age. Most of the boreholes penetrate tuffaceous members of the Tertiary Paintbrush Tuff. The Paintbrush Tuff consists of four members; they are, in descending stratigraphic order, Tiva Canyon, Yucca Mountain, Pah Canyon, and Topopah Spring. All bedded tuffs between each member encountered in the existing holes are part of the Paintbrush Tuff. Most boreholes penetrated a combination of lithologies. These descriptions include names of the lithologic subunits of the Tiva Canyon and the Topopah Spring Members of the Paintbrush Tuffs originally defined by Scott and Bonk (1984). The terms that describe degree of welding, in increasing order, are nonwelded, partially, moderately, and densely.

One exception was noted concerning the lithologic subunits as defined by Scott and Bonk (1984). The nonwelded to partially welded, vitric portion of the columnar zone in the lower Tiva Canyon Member is identified in this report as a separate subunit. This subunit, named the "shardy base," was encountered in boreholes UZN \#10, UZ-N24, and UZ-N98. The shardy base has been separated from the columnar zone based on the degree of welding and fracture density, both of which influence the hydrologic properties of the subunit.

\section{GEOPHYSICAL LOGS}

After drilling was completed for each neutronaccess borehole, the borehole was logged with a neutron-moisture meter. Logging is currently done only in the cased section of the borehole with the probe decentralized. All 74 holes are logged on a regular schedule and more frequently after substantial precipitation events.

\section{TESTING PROCEDURES AND RESULTS}

All testing procedures are described in detail in Hammermeister and others (1986). Gravimetric watercontent procedures were followed in the onsite laboratory by standard gravimetric oven-drying methods (Gardner, 1986). Water-potential measurements were determined at the U.S. Geological Survey hydrologic laboratory on the Nevada Test Site, using a Richards psychrometer (Rawlins and Campbell, 1986). Bulkand grain-density measurements were made on selected drive-core and rotary-core samples by Holmes and Narver Materials Testing Laboratory, Mercury, Nevada, using Standard American Society of Testing and Materials procedures. Porosity values were calculated from bulk and grain-density measurements. Tritium concentrations were measured by the U.S. Geological Survey Tritium Laboratory in Reston,
Virginia. This laboratory uses vacuum-distillation methods to extract water from samples and standard scintillation methods to measure tritium concentrations.

\section{PRELIMINARY GEOHYDROLOGIC EVALUATIONS}

\section{Water-Content Measurements}

Gravimetric water-content measurements were determined on various types of geologic samples from the neutron-access boreholes. The results for drillcutting samples are presented in table 4. The results for drive core and rotary core samples are presented in table 5. Both tables are in the "Supplemental Data" section at the back of the report. Each depth in table 4 represents a midpoint of a drilled interval.

Statistical methods used to describe the mean, standard deviation, and median of gravimetric watercontent data as a function of major lithologic units and the degree of welding are presented in tables 6 and 7 in the "Supplemental Data" section at the back of the report. In nearly every lithologic unit, the median is less than the mean value of the hydrologic characteristic. This consistent trend is not typical of data that have a normal cumulative-frequency distribution. Probability plots of the cumulative-frequency distribution of hydrologic data, from a number of lithologic units, generally indicate that these data are log-normally distributed (Hald, 1952). In this report, the hydrologic data will be assumed to be log-normally distributed; therefore, the median will be used as the best estimate for the central tendency.

A comparison of coarse drill-cuttings data (table 6) with core data (table 7) indicates that drill cuttings have a slightly smaller median gravimetric watercontent value than core for each major rock unit. This was expected because drill cuttings have a larger surface-area-to-volume ratio than core samples and, therefore, are more susceptible to water loss due to evaporation.

Even though coarse drill cuttings are slightly drier than core samples, in most instances, the gravimetric water-content values (and water-potential values, discussed later in the Water-Potential Measurements section) of coarse drill cuttings correlated with core-sample values obtained from the same depth interval. The results of a linear-regression analyses between gravimetric water-content values of these two different geologic samples, obtained from the same depth interval, for rock types defined on the basis of welding are summarized in table 8 in the "Supplemental Data" sec- 
tion at the back of the report. Rock types were not further subdivided by lithology for this correlation (as in tables 6 and 7), in order to keep the sample size as large as possible. The relatively large coefficient of determination (table 8) indicates that coarse drill cuttings can be used in conjunction with regression equations to estimate the water content of core samples. Hammermeister and others (1986) also have presented evidence that indicates that the water-content values of core samples are, in turn, good estimates of the water-content values of the formation rock.

A high correlation was determined among watercontent values of samples in moderately and densely welded tuffs (table 8). The average particle size of coarse drill cuttings from this rock type was generally much larger than the coarse particle size from other rock types. This, in addition to the smaller porosity (to be discussed later in the Bulk- and Grain-Density Measurements and Porosity Calculations section) of the moderately and densely welded tuffs, probably minimizes the alteration of water content by evaporation.

Hammermeister and others (1986) also have determined that, in general, water-content values of composite core samples had a higher correlation with water-content values of coarse particle-size fractions of drill cuttings at the same depth interval than either fine or composite particle-size fractions of drill cuttings. This analysis was made on data from a number of neutron-access boreholes drilled early in the program. As a result of this analysis, only sieved, coarse drill cuttings were collected for gravimetric water-content and water-potential measurements in the majority of all subsequently drilled neutron-access boreholes.

Examples of water-content profiles for different particle-size fractions of drill cuttings from boreholes drilled in different surficial rock units are shown in figure 3. The coarse and composite data are in fair agreement throughout UZN \#56, which was drilled in alluvium/colluvium from the surface to a depth of $17.07 \mathrm{~m}$, and in the lower part of UZ-N96, which was drilled in welded tuff from $0.61 \mathrm{~m}$ to $10.67 \mathrm{~m}$. The fine particle-size fraction is wetter than the other fractions in alluvium/colluvium. In-situ fine particle-size fractions in alluvium/colluvium have a much different pore-size distribution than coarse fractions composed mainly of welded tuff fragments. These same differences in pore-size distribution probably occur in the drill cuttings. If the water in the fine and coarse particle-size fractions is in approximate energy equilibrium, the fine particle-size fraction will retain a greater quantity of water because of its larger porosity and greater average pore size. At this time, it is not known why fine particle-size cuttings (produced by the drilling pro- cess from consolidated rock) of the welded tuff in the upper section of UZ-N96 are wetter than other fractions. In the lower part of the hole, preferential drying of the fine particles due to the large surface-area-tovolume ratio probably explains the smaller water-content values that were measured.

The sieving of drive-core samples from selected boreholes also provides information on the distribution of water among particle-size fractions. Examples of results for two boreholes located in different topographic positions in a canyon bottom are shown in figure 4. The trends in data are similar to those that occur for alluvium/colluvium drill cuttings (fig. 3 ).

Some general trends in water-content data can be discerned from tables 6 and 7 without doing statistical analysis. In general, samples from nonwelded and bedded tuffs are wetter than samples from moderately welded tuffs which, in turn, are wetter than samples from densely welded tuffs. Moderately to densely welded tuffs were combined with densely welded tuffs in this analysis. The degree of welding in tuffaceous rock is known to affect the porosity and, therefore, the pore-size distribution of the matrix of this rock (Scott and others, 1983). Increases in the degree of welding result in a decrease in matrix porosity. Although little data exist, increased welding also results in a decrease in the median pore radius in samples. The pore-size distribution, in part, determines the quantity of water (water content) and the energy of the water (water potential) held in the porous matrix.

Statistics describing the central tendency and dispersion of water-content data for separate lithologic subunits in the welded sections of the Tiva Canyon Member are listed in tables 9 and 10 in the "Supplemental Data" section at the back of the report.

Differences in standard deviation (variances) are apparent in the data and also occurred in the log-transformed data. Because of these differences in variances, the mean values of these units cannot be compared by standard parametric statistical analysis. Comparisons of the mean or median values of these lithologic subunits, and the major lithologic units (also having unequal variances) noted in tables 6 and 7 , need to be made using nonparametric methods.

Knowledge of the equality or inequality of mean values of water content and other hydrologic characteristics are needed to help define or redefine hydrogeologic surficial and subsurface units on Yucca Mountain. As mentioned earlier, preliminary hydrogeologicsurficial units have been defined mainly on the basis of the lithology of subunits of the welded Tiva Canyon Member. These preliminary definitions will be redefined based on the results of these statistical comparisons of hydrologic characteristics among rock units. 


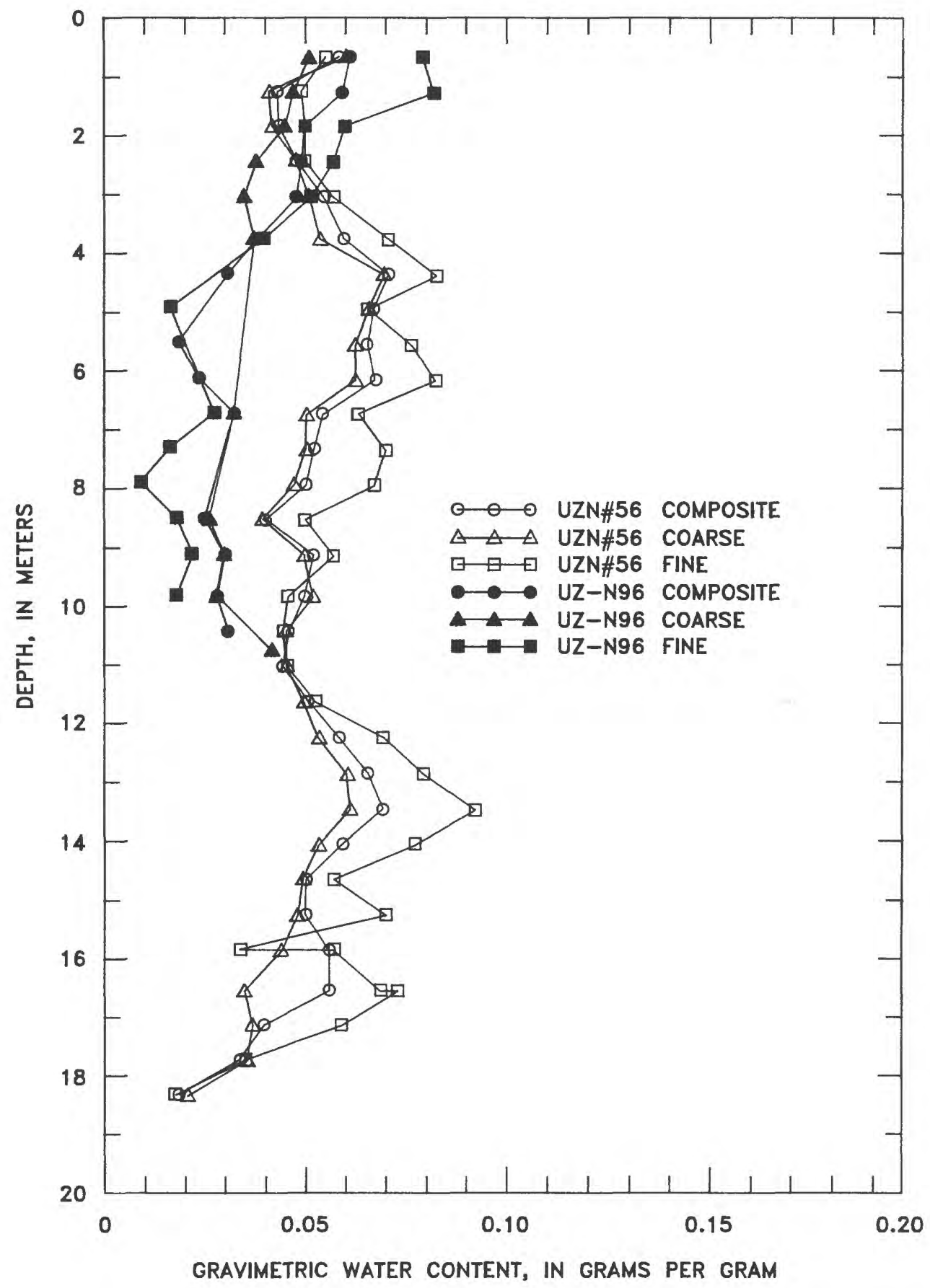

Figure 3.--Water-content profiles for different particle-size fractions of drill-cutting samples from two boreholes. 


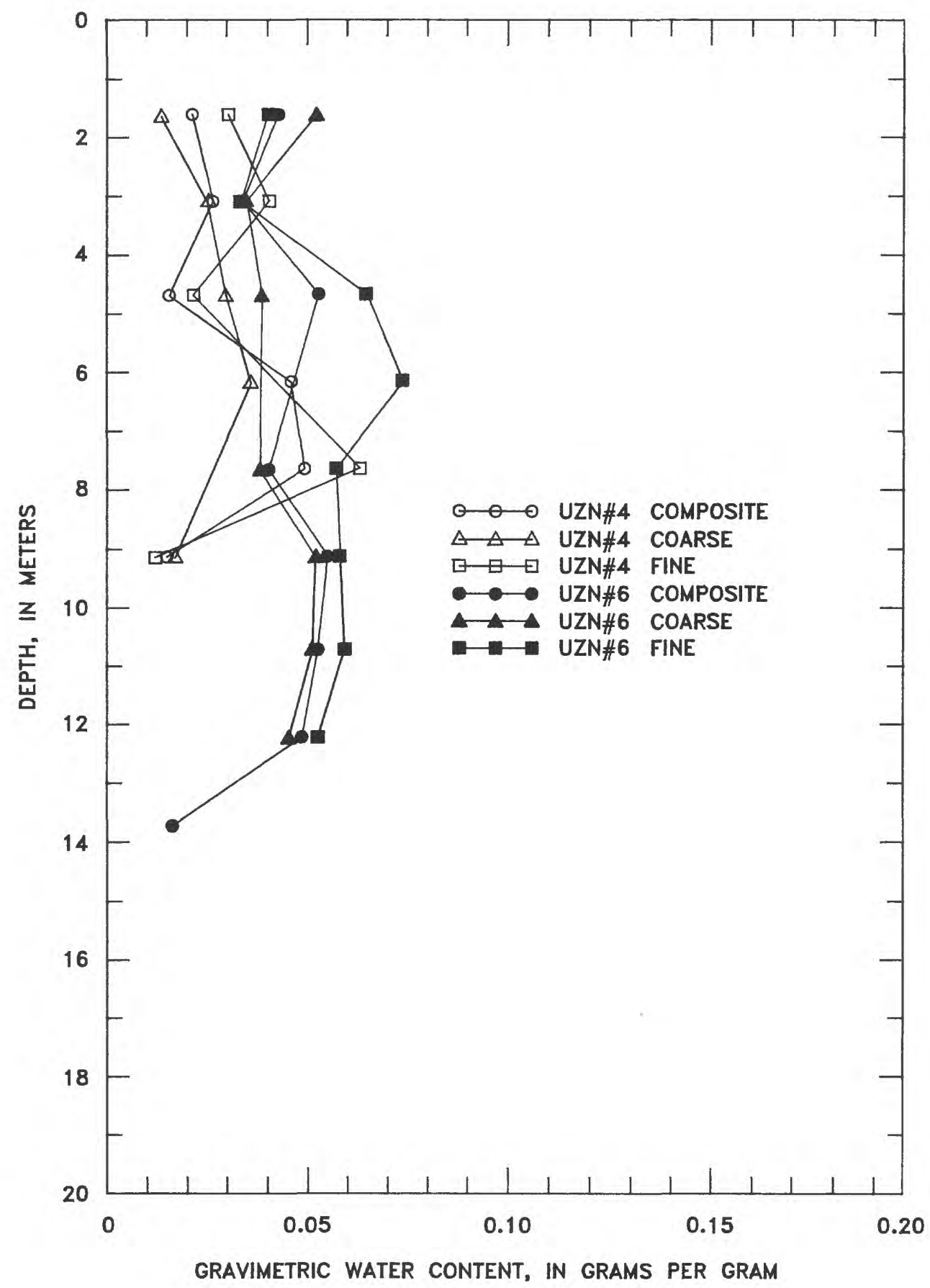

Figure 4.--Water-content profiles for different particle-size fractions of drive-core samples from two boreholes located in different topographic positions in alluvium/colluvium, UZN\#4 is located on a terrace and UZN\#6 is in an active drainage channel. 
Large differences in median water-content values occurred among some welded lithologic surficial subunits of the Tiva Canyon Member penetrated by boreholes (tables 9 and 10). The drill cuttings of the densely welded upper lithophysal subunit seems to be much wetter than the other densely welded subunits (table 9).

\section{Water-Potential Measurements}

Water-potential measurements were done on various types of geologic samples from the neutron-access boreholes. The results for drill-cutting samples are presented in table 4 . The results for drive-core and rotarycore samples are presented in table 5. Both tables are in the "Supplemental Data" section at the back of the report. Each depth in table 4 represents a midpoint of a drilled interval.

The water potential of a sample is dependent upon the water content of that sample and its previous wetting and drying history. Therefore, many of the same trends discussed previously for water-content data also are expected to occur in water-potential data. However, because the relation between the water potential and water content of a sample is very nonlinear, a number of substantial differences also are expected.

A comparison of the median water-potential values of drill-cuttings and core data collected for all major lithologic units divided on the basis of the degree of welding indicates that the median values of cuttings are generally smaller than those for core (tables 11 and 12 in the "Supplemental Data" section at the back of the report). Exceptions to this were values from the densely welded Tiva Canyon Member and the moderately welded Yucca Mountain Member.

At the same time, the results of regression analyses (table 8) indicated a fairly significant correlation of water-potential values of coarse drill cuttings compared to core samples obtained from the same depth intervals for alluvium/colluvium and moderately and densely welded tuffs. The smaller correlation that occurred in nonwelded and bedded units in part is because of the extra drying that occurred during the coring and reaming process. Continuous core was collected for long intervals in all nonwelded and bedded tuff sections of boreholes before these sections were reamed and cuttings were collected. This long exposure to circulating air during coring would preferentially dry these sections and would result in smaller water-content and water-potential values. Water potential is dependent upon water content and, in many instances, a small change in water content caused by drying can result in a very large change in water potential.

Median water-potential values (as with median water-content values) of drill cuttings and core samples vary with lithology and tend to decrease as the degree of welding increases within a particular lithologic unit (tables 11 and 12). The smaller water-potential values of drill cuttings from nonwelded to partially welded tuffs seem to be an exception to this trend. As mentioned earlier, these data may contain errors caused by the extra drying that occurred during the coring and reaming process.

Finally, noticeable differences in median waterpotential values are apparent among some of the lithologic subunits of the moderately and densely welded sections of the Tiva Canyon Member (tables 13 and 14 in the "Supplemental Data" section at the back of the report).

\section{Examples of the Spatial Variability of Water- Content and Water-Potential Data}

This section will present specific examples of the spatial variability of hydrologic characteristics to explain the complexity of spatial relations at Yucca Mountain. The U.S. Geological Survey has developed comprehensive plans, and work is planned that will use geostatistical methods (Journel and Huijbregts, 1978) to describe the spatial variability of hydrologic characteristics over the surface of Yucca Mountain. The methods are to model the spatial relations of data collected at different locations, estimate the distribution of median values and variances of characteristics over the mountain, and determine the level of uncertainty associated with these median values.

Examples of ranges in the spatial variability of hydrologic characteristics in surficial rocks are most easily illustrated by examining water-content and water-potential profiles from a series of boreholes located on an approximately west-to-east transect over the proposed repository. Profiles will be compared in pairs of closely spaced boreholes that penetrate similar lithologic units and are located in similar topographic positions. Beginning in Solitario Canyon, on the west side of Yucca Mountain, almost identical profiles of both characteristics are shown in UZ-N89 and UZ-N90 (figs. 5 and 6), which are spaced approximately $1 \mathrm{~m}$ apart in the center of an alluvium/colluvium channel. Very different profiles are shown in UZ-N84 and UZ-N87 (figs. 7 and 8), drilled approximately $1 \mathrm{~m}$ apart on a terrace almost $100 \mathrm{~m}$ to the east of UZ-N89 and UZ-N90. Very large increases in water-content and water-potential values in UZ-N84 at approximately 


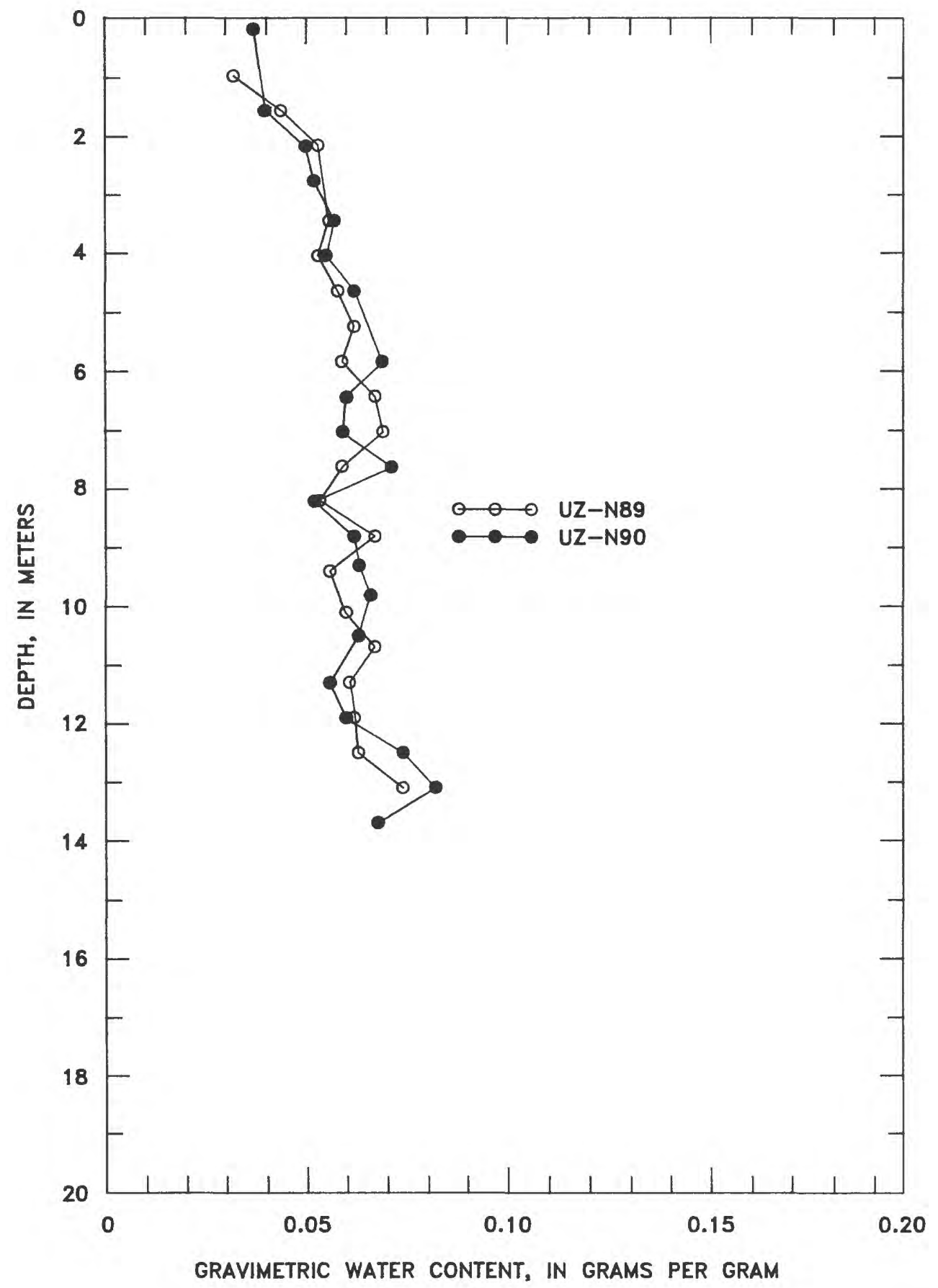

Figure 5.--Water-content profiles for boreholes UZ-N89 and UZ-N90 located approximately 1 meter apart in a channel in alluvium/colluvium. 


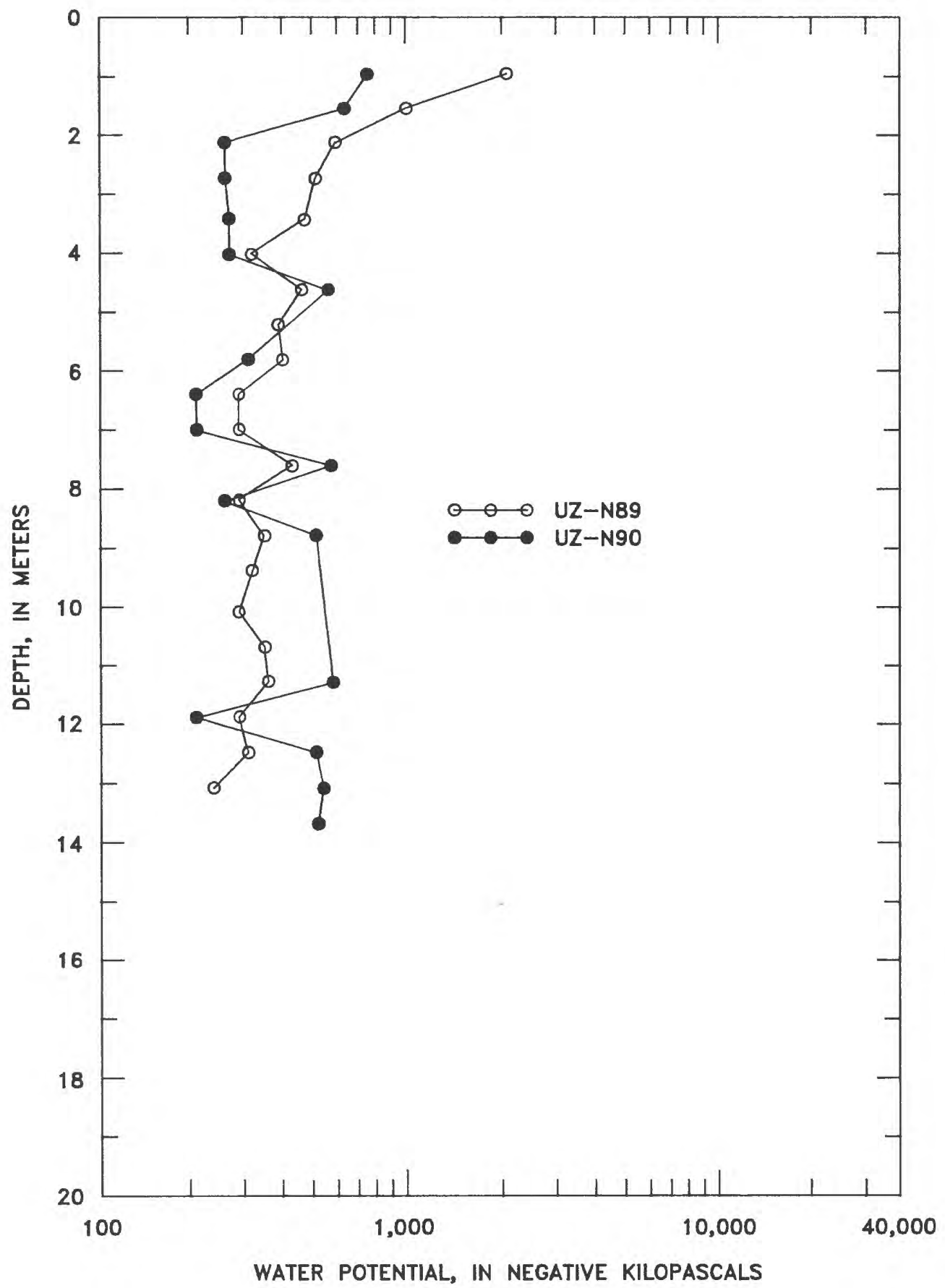

Figure 6.--Water-potential profiles for boreholes UZ-N89 and UZ-N90 located approximately 1 meter apart in a channel in alluvium/colluvium. 


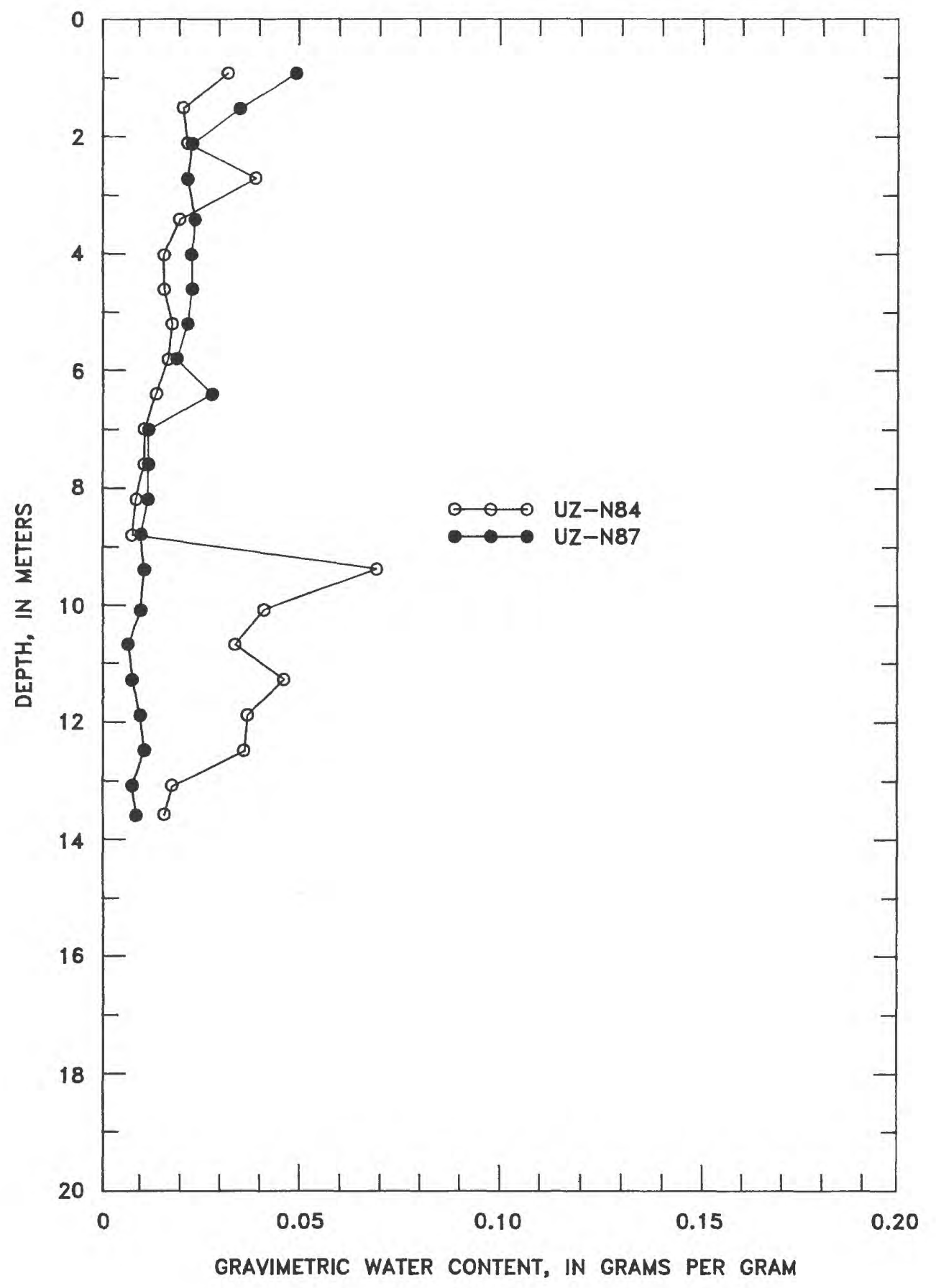

Figure 7.--Water-content profiles for boreholes UZ-N84 and and UZ-N87 located approximately 1 meter apart on a terrace where alluvium/colluvium overlies welded tuff. 


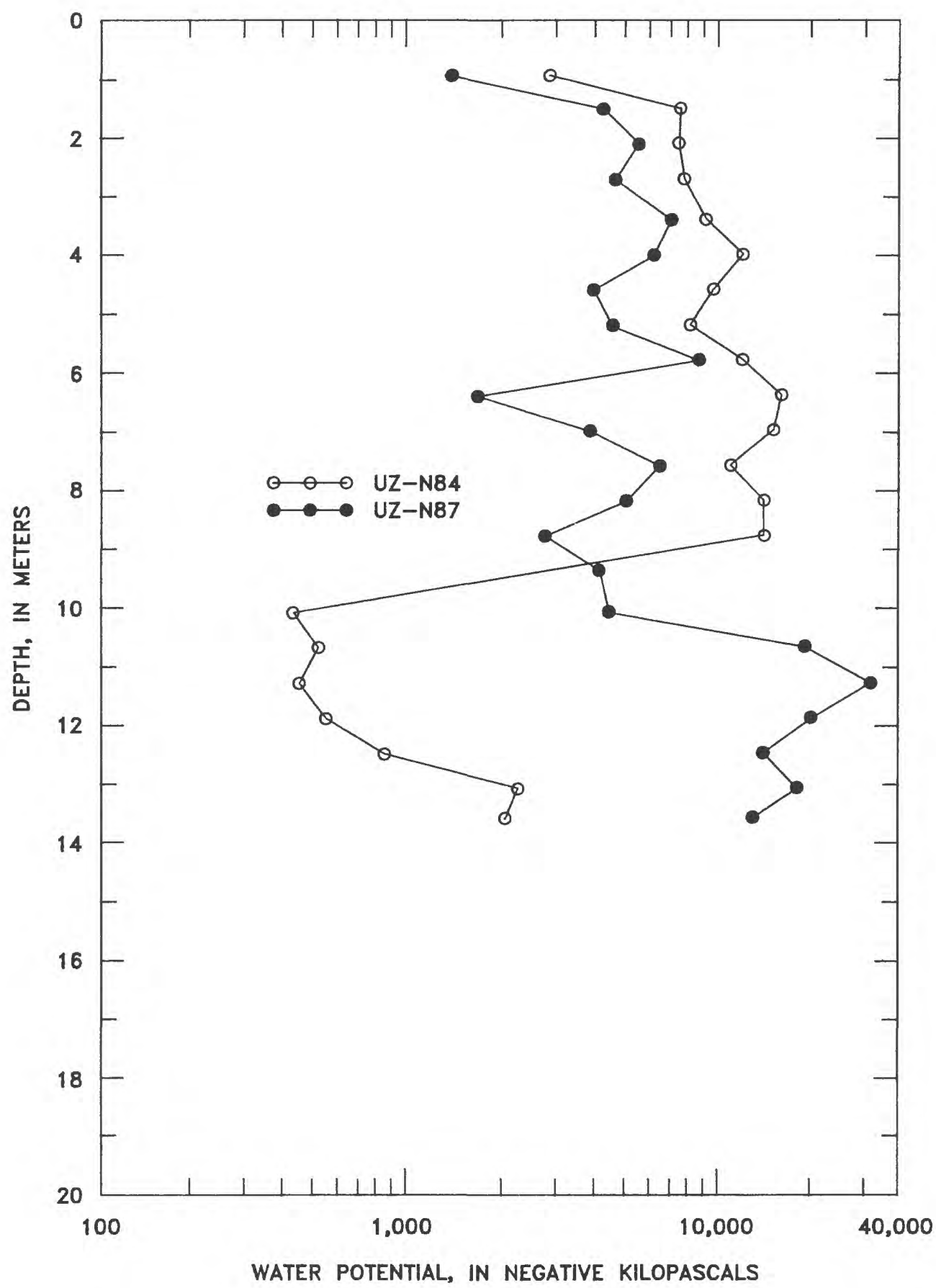

Figure 8.--Water-potential profiles for boreholes UZ-N84 and UZ-N87 located approximately 1 meter apart on a terrace where alluvium/colluvium overlies welded tuff. 
9.4 m corresponds to a sharp change from moderately to densely welded lithology, probably caused by faulting (table 3). The faulting and lithology change are not observed in the nearby hole UZ-N87. No evidence of this faulting is observable at the ground surface. The water-content and water-potential values below $9.4 \mathrm{~m}$ in UZ-N84 are among the largest values recorded for welded tuff sections of holes at Yucca Mountain. Plans have been made to attempt to further characterize and understand the effects of faulting on the hydrologic flow system, using borehole, seismic, and geotomographic geophysical methods in conjunction with artificial infiltration techniques.

Approximately 175 m east of UZ-N87, two boreholes, UZ-N83 and UZ-N86, were drilled approximately $30 \mathrm{~m}$ apart in the same exposed lithologic unit in a channel bottom. Water content and water-potential profiles in these boreholes were very similar (figs. 9 and 10). Approximately $800 \mathrm{~m}$ to the east, UZN75 and UZ-N76 were drilled in moderately welded tuff near the crest of Yucca Mountain, also approximately $30 \mathrm{~m}$ apart. Profiles from these two boreholes are quite different (figs. 11 and 12). The lithologic log of UZ-N76 indicates a substantial degree of fracturing and abundant secondary carbonate the entire depth of the borehole (table 3). Again, there is no evidence of this fracturing at the ground surface.

Finally, approximately $2,000 \mathrm{~m}$ to the east of UZ-N75 and UZ-N76, UZN \#28 and UZN \#97 located $1 \mathrm{~m}$ apart in alluvium/colluvium in a braided channel area, are two boreholes that have similar water-content and different water-potential profiles (figs. 13 and 14). This pair of boreholes show much more variability in hydrologic characteristics than the two boreholes in alluvium/colluvium, discussed previously, at the west end of the transect (figs. 5 and 6).

As expected in shallow boreholes, some of the spatial variability seems to be related to topographic positions. Water-content profiles seem to be wetter and water-potential profiles less negative in boreholes drilled beneath channels in alluvium/colluvium than in those drilled beneath alluvial/colluvial terraces. Examples of this are shown in figures 15 and 16, where UZN\#13 is located in the center of a channel, and $\mathrm{UZN} \# 14$ is approximately $15 \mathrm{~m}$ away on a terrace. Differences in water-content profiles beneath channels (UZN \#6) and terraces (UZN \#4) are shown in figure 4.

In some instances, differences in water-content and water-potential profiles are noted between boreholes located in exposed welded tuff in channel bottoms with no alluvial/colluvial cover, and boreholes located in exposed bedrock on adjacent hillsides. These differences for different rock units are shown in figures $17,18,19$, and 20 . In figures 17 and 18, the lithology of the entire depth of UZ-N86 and the lower part of UZ-N88 is clinkstone (table 3). Water-content and water-potential values in the upper lithophysal unit in UZ-N88 $(0.23-4.27 \mathrm{~m})$ are less than those that occur in the clinkstone unit of UZ-N86. This is especially noticeable in water-potential data, which reach an extreme in the upper lithophysal unit near the clinkstone-unit contact. The entire depth of UZ-N72 and the lower part of UZ-N74 $(5.79-11.28 \mathrm{~m})$ penetrate the upper cliff lithologic subunit (figs. 19 and 20). The upper part of UZ-N74 is in the caprock unit. Again, water-content and especially water-potential values increase to a maximum near the contact of the two lithologic units. This phenomena of decreasing hydrologic characteristics in an upper unit near the contact with a lower unit was noted in other boreholes that penetrated welded lithologic subunits of the Tiva Canyon Member.

Very limited vertical spatial variability occurs within individual boreholes that penetrate thick lithologic units. Little variability in water-potential and water-content profiles is especially significant within a unit of constant lithology because it indicates a steadystate flow system in this unit. In these thick lithologic units, constant water-potential profiles permit the assumption of a unit hydrologic gradient and simplify the calculation of flux. Thick intervals of constant water potential and water content were noted in nearly all of the boreholes on the west-to-east transect mentioned above. These boreholes penetrate the majority of lithologic units that occur on or near the surface of Yucca Mountain.

\section{Bulk- and Grain-Density Measurements and Porosity Calculations}

Bulk- and grain-density measurements and porosity calculations are presented for rotary-core samples from a few selected boreholes that penetrated nonwelded and bedded tuff rock units (table 15 in the "Supplemental Data" section at the back of the report). These tests were done in conjunction with prototype borehole geophysical-logging tests designed to develop field calibration methods for moisture-sensitive nuclear-logging tools. A more comprehensive matrix hydrologic-testing program of rotary-core samples, which is designed to indicate the spatial variability of these properties, is planned for Yucca Mountain.

Bulk density, grain density, porosity, and volumetric water content were measured on drive-core samples from two boreholes. These data and associated problems have been described elsewhere (Ham- 


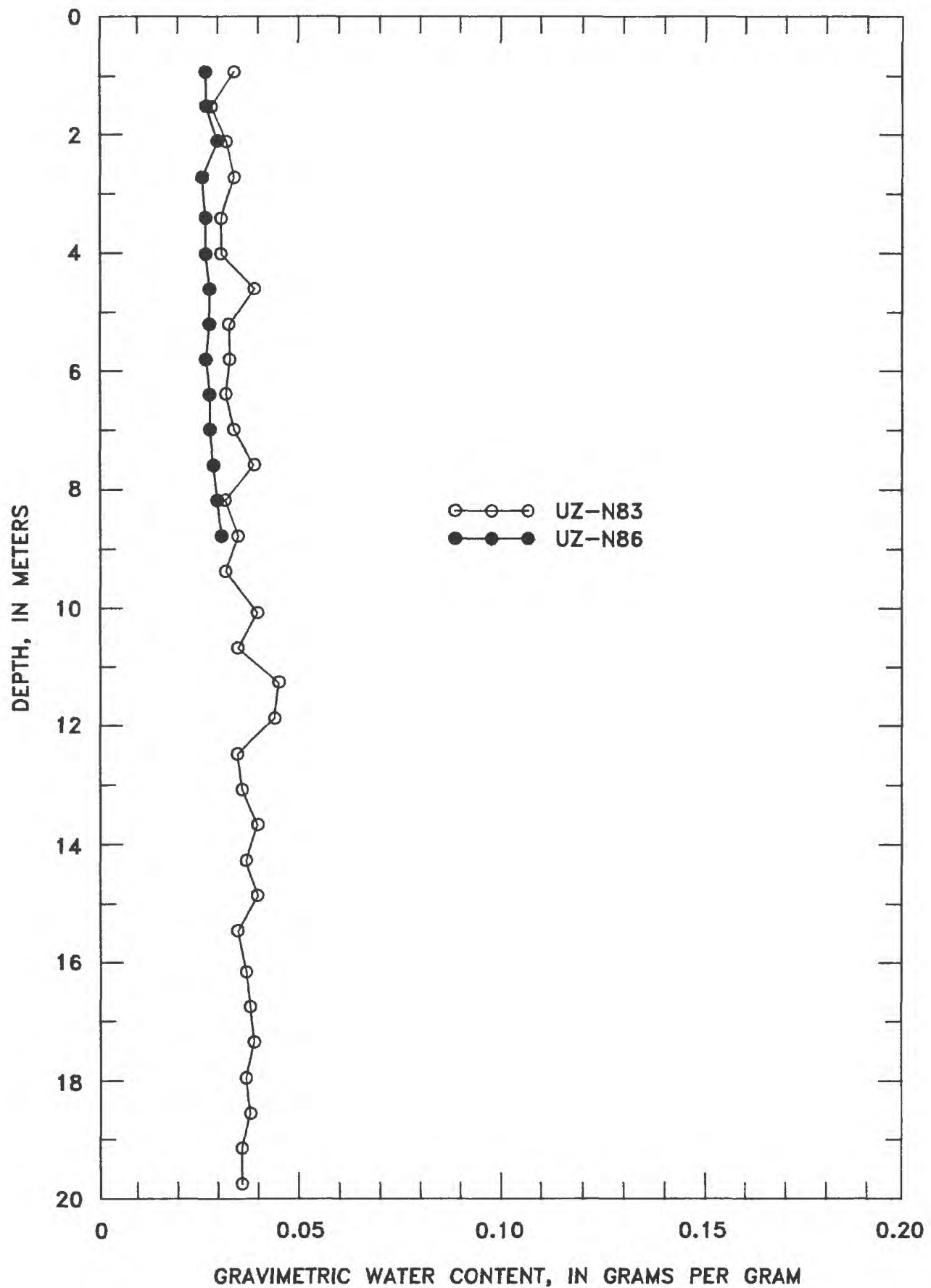

Figure 9.--Water-content profiles for boreholes UZ-NB3 and and UZ-NB6 located approximately 30 meters apart in welded tuff exposed in a channel. 


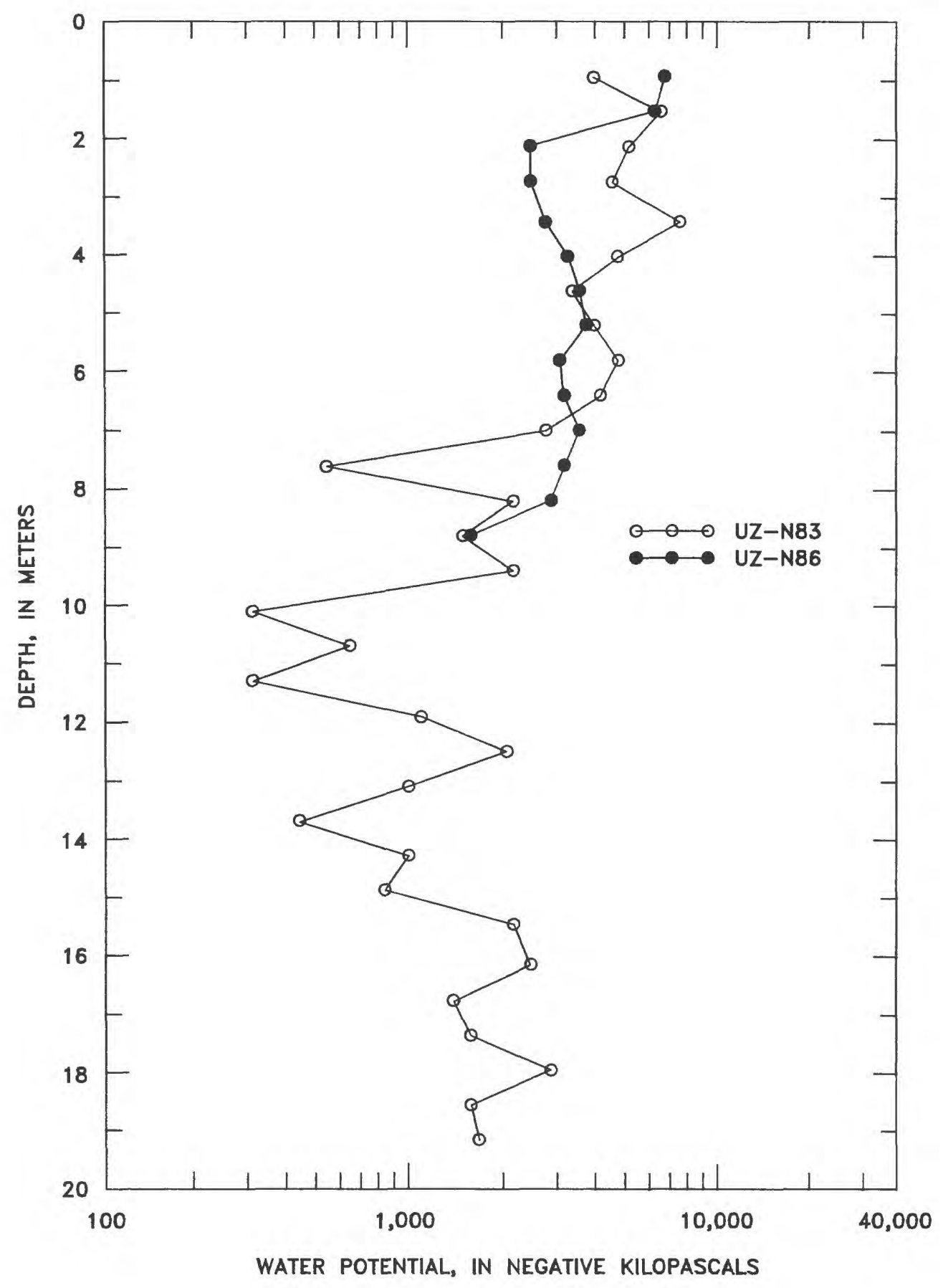

Figure 10.--Water-potential profiles for boreholes UZ-N83 and UZ-N86 located approximately 30 meters apart in welded tuff exposed in a channel. 


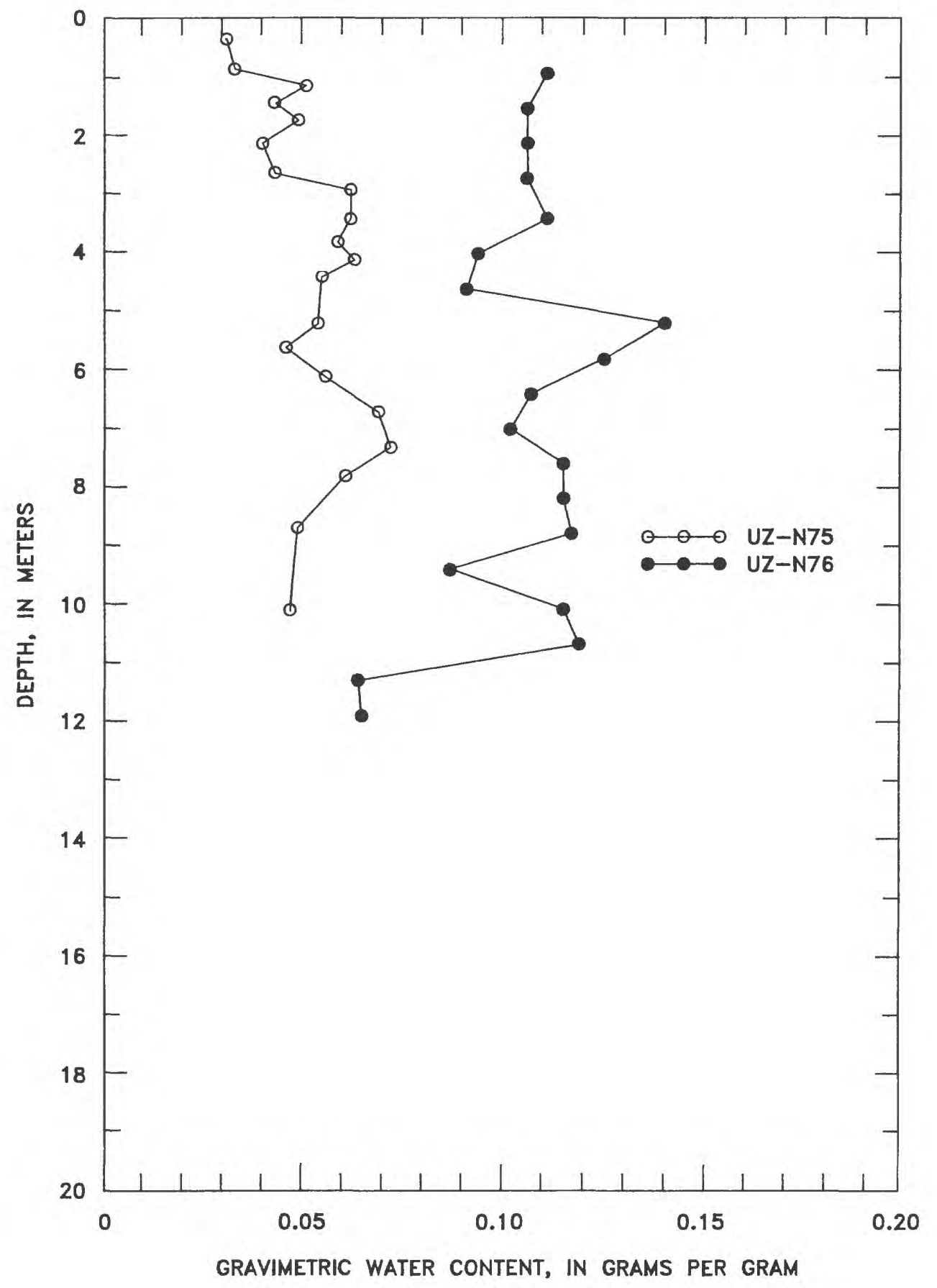

Figure 11.--Water-content profiles for boreholes UZ-N75 and UZ-N76 located approximately 10 meters apart in moderately welded tuff near the crest of Yucca Mountain. 


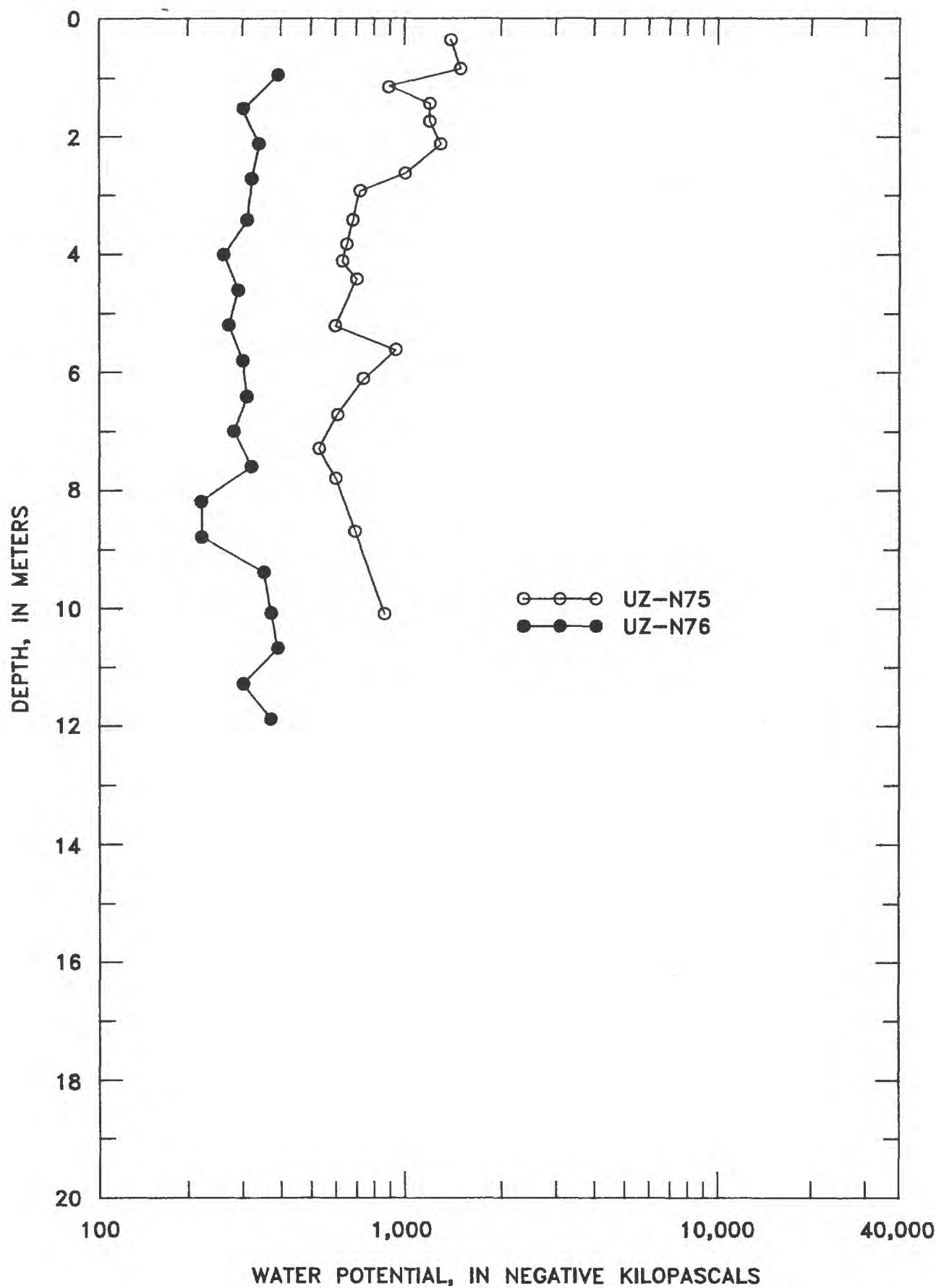

Figure 12.--Water-potential profiles for boreholes UZ-N75 and UZ-N76 located approximately 10 meters apart in moderately welded tuff near the crest of Yucca Mountain. 


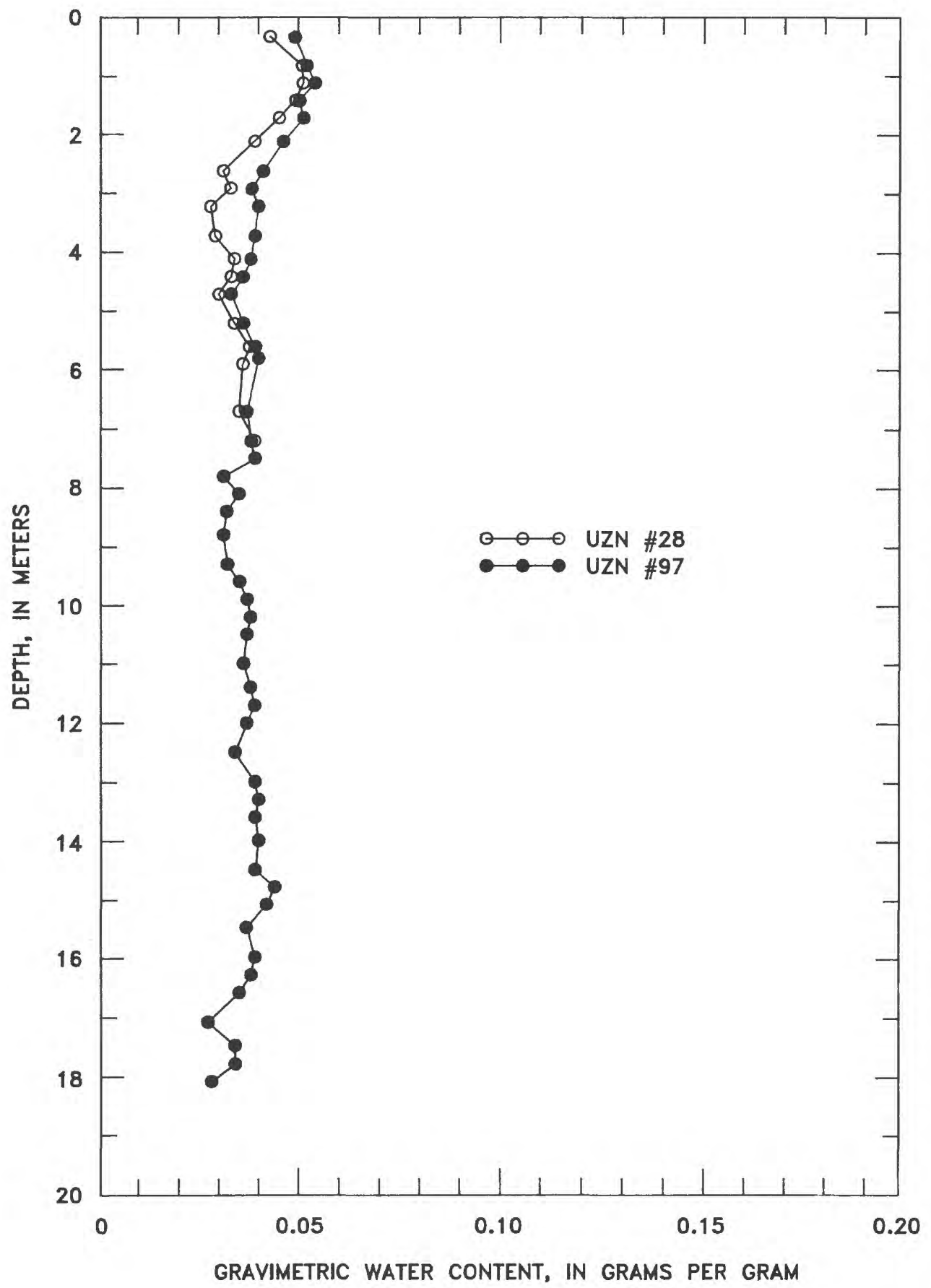

Figure 13.--Water-content profiles for boreholes UZN \#28 and UZN \#97 located approximately 1 meter apart in a braided channel area of alluvium/colluvium. 


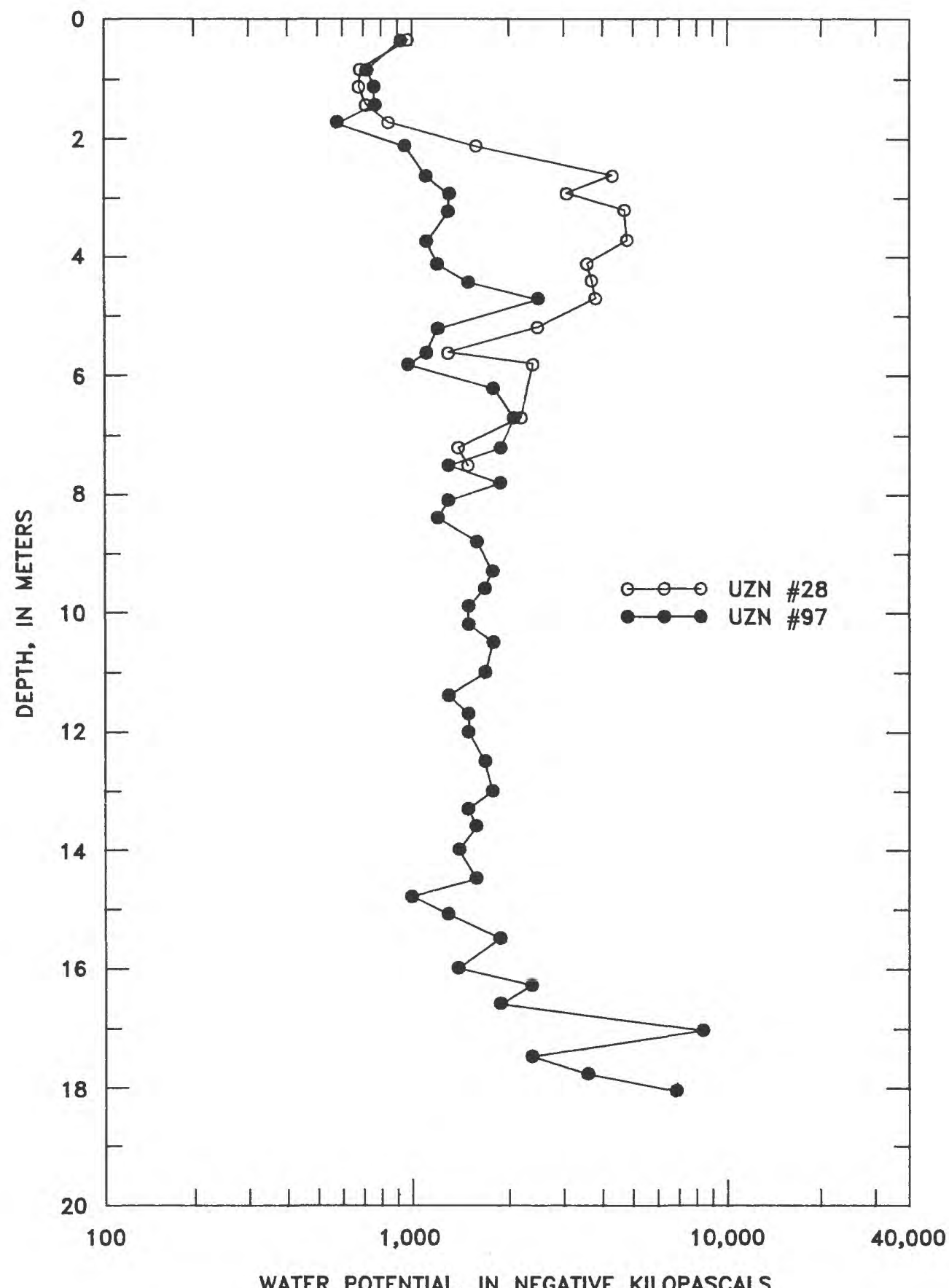

Figure 14.--Water-potential profiles for boreholes UZN \#28 and UZN \#97 located approximately 1 meter apart in a braided channel area of alluvium/colluvium. 


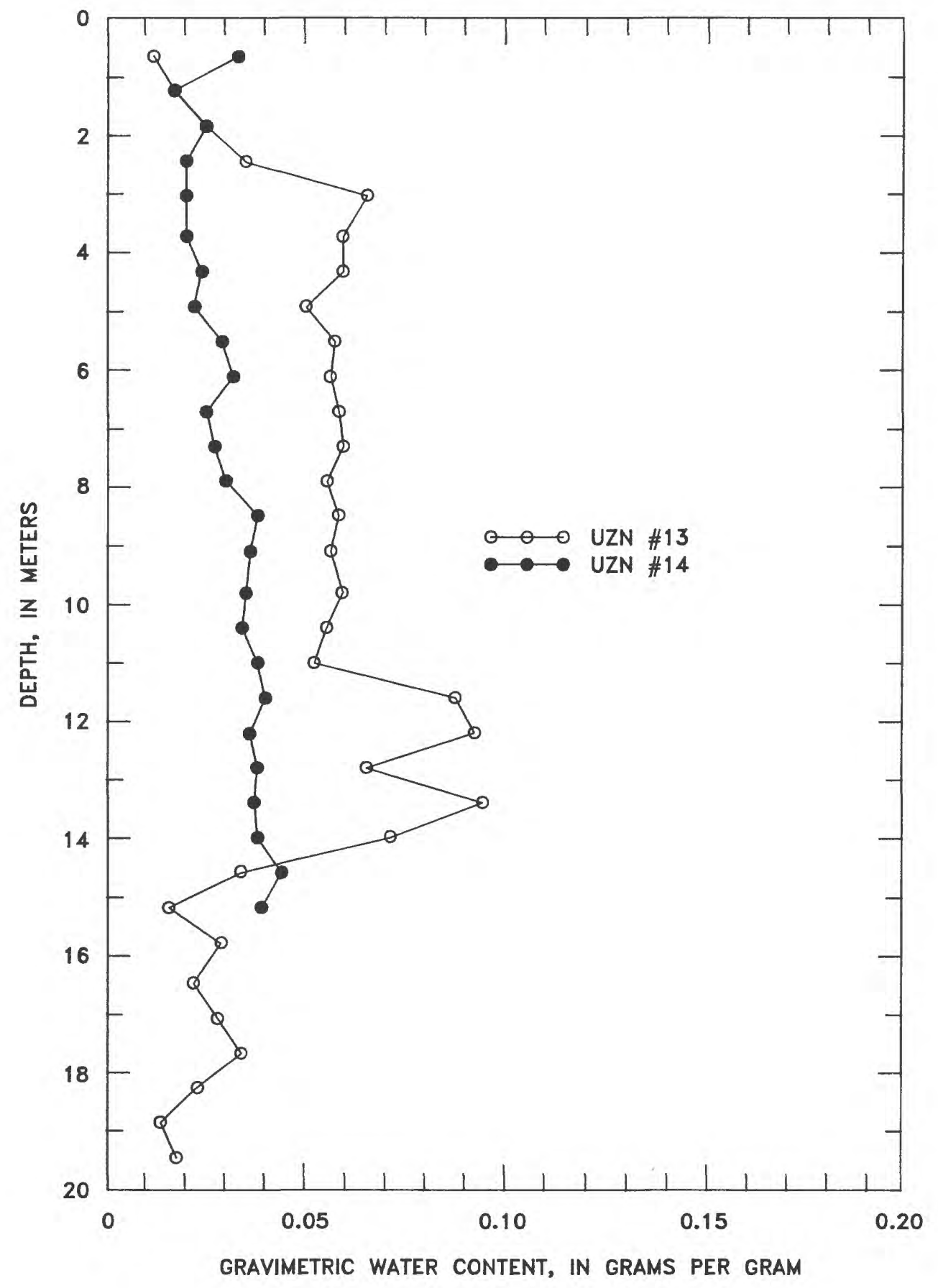

Figure 15.--Water-content profiles for boreholes UZN \#13, located in an active drainage channel, and UZN \#14, located on a terrace, both boreholes in alluvium/ colluvium. 


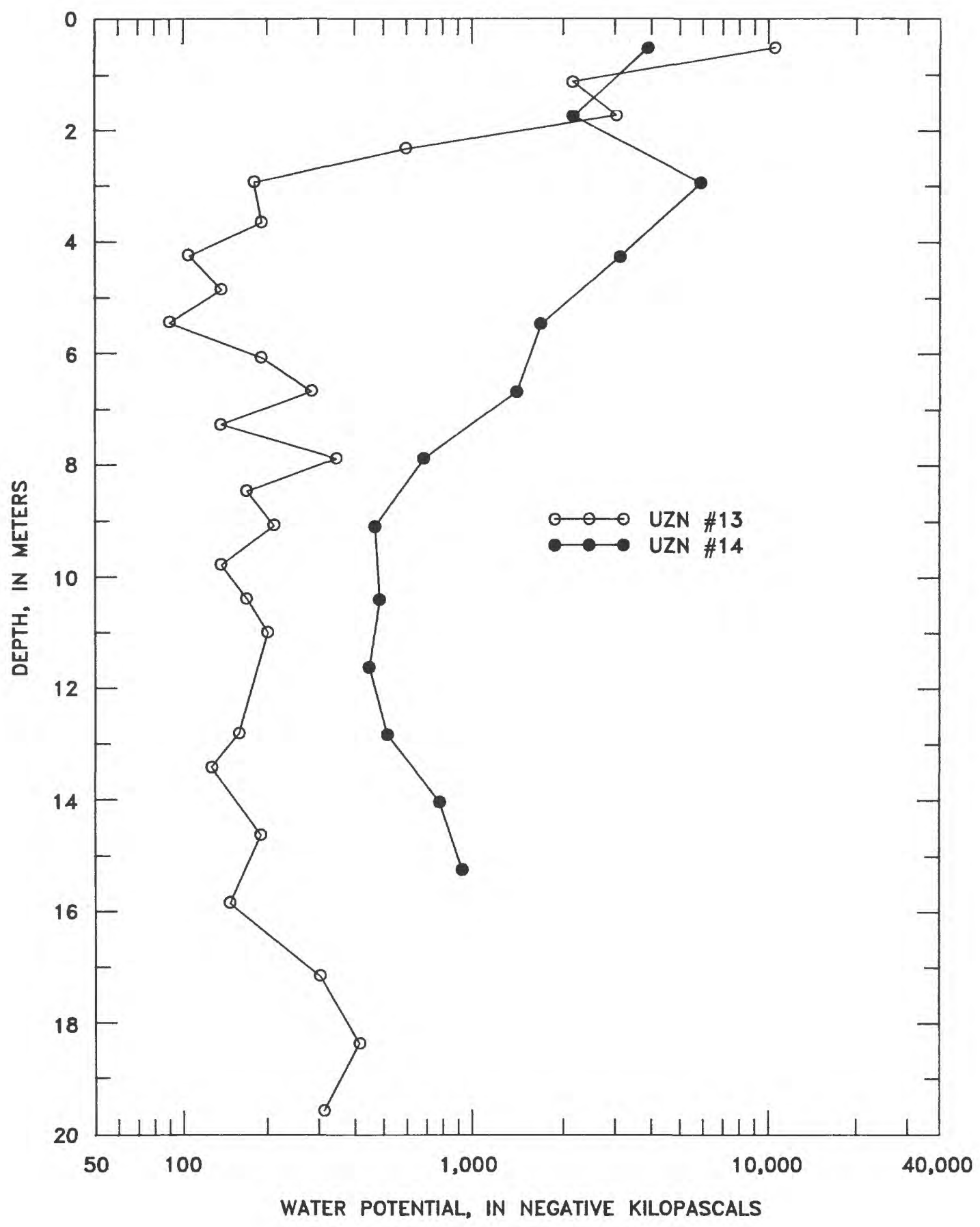

Figure 16.--Water-potential profiles for boreholes UZN \#13, located in an active drainage channel, and UZN \#14 located on a terrace, both boreholes in alluvium/ colluvium. 


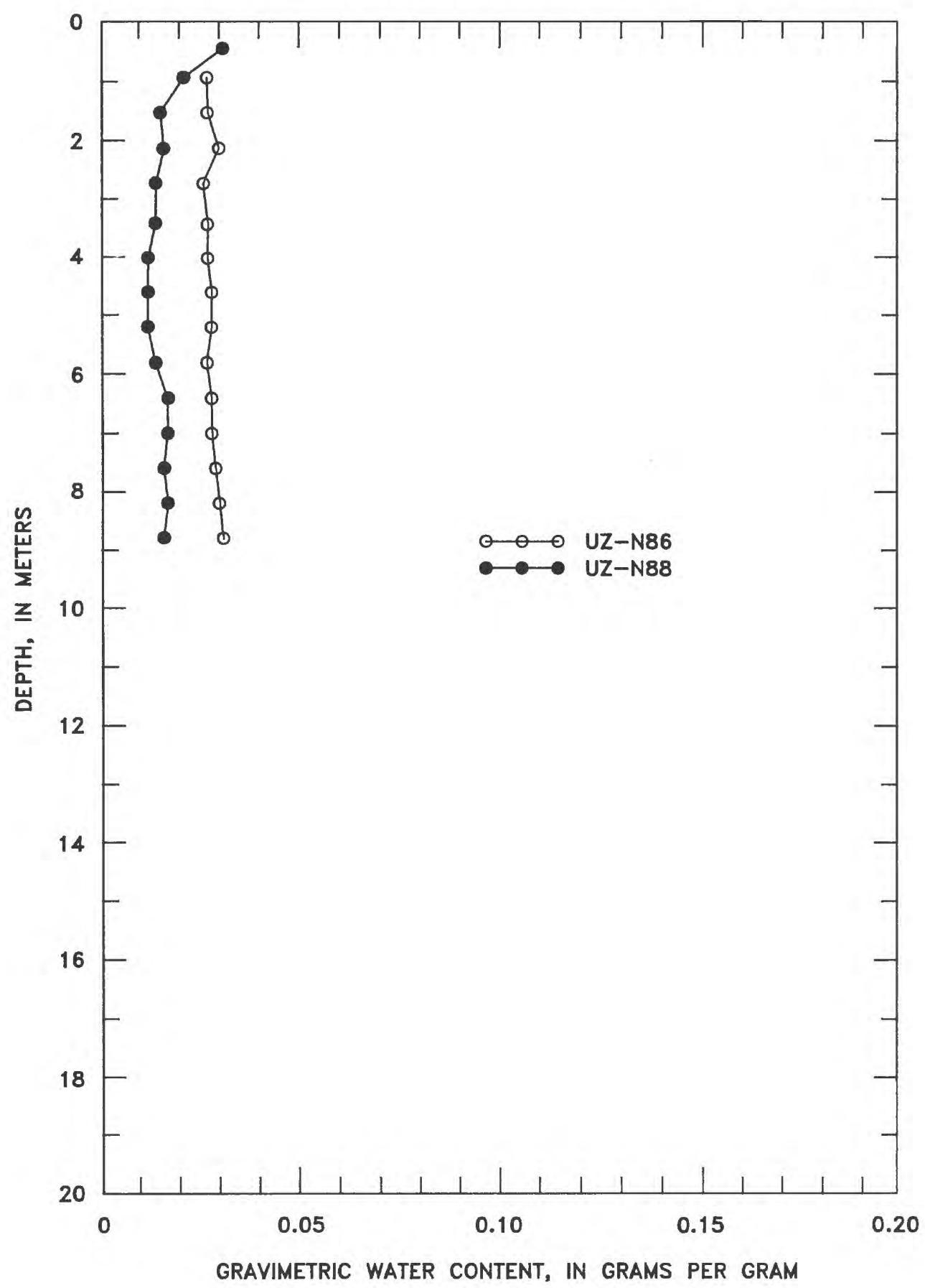

Figure 17.--Water-content profile for borehole UZ-N86 located on an exposed bedrock channel compared to a profile from borehole UZ-N88 located on exposed bedrock on an adjacent hill slope. 


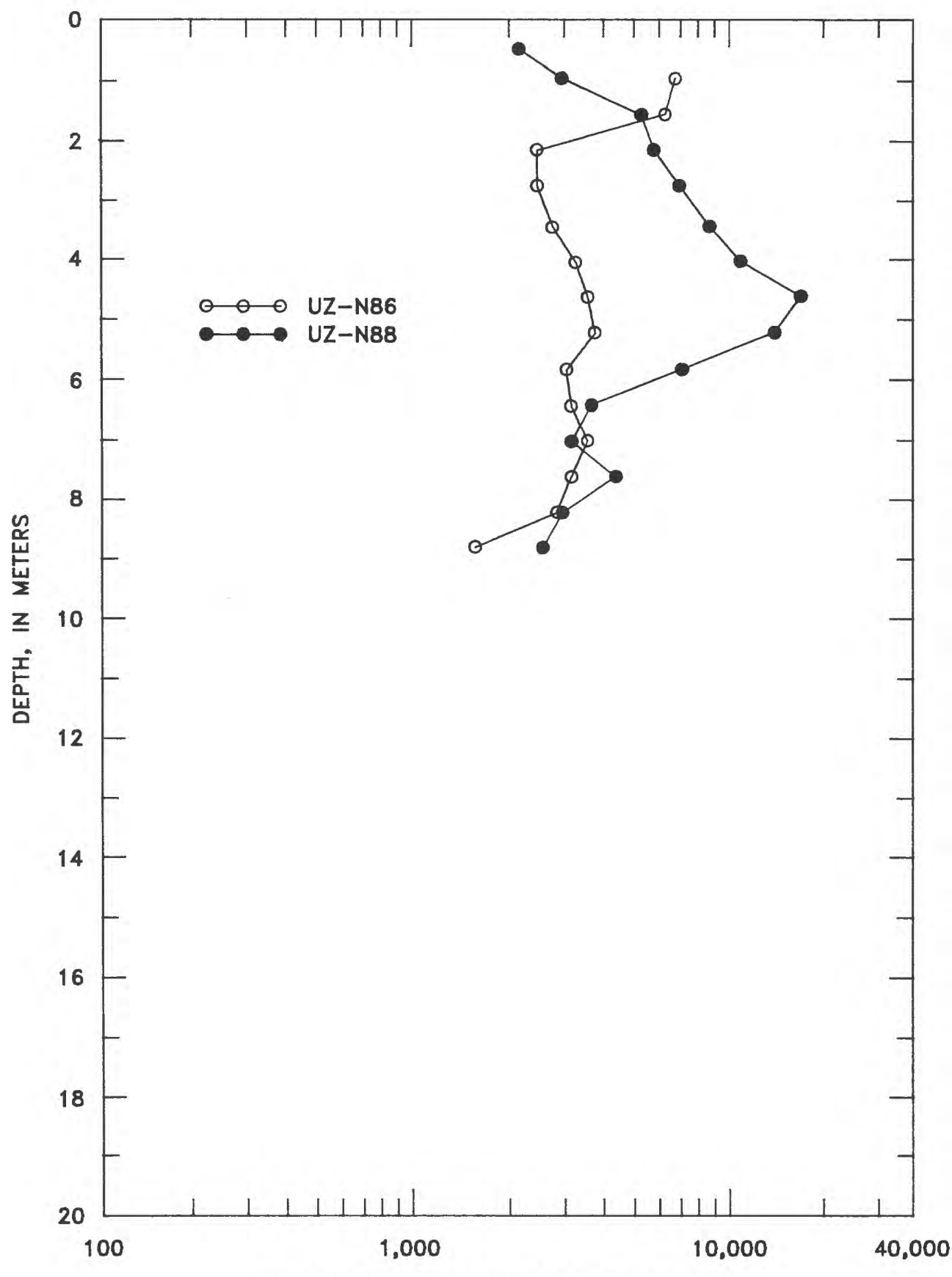

WATER POTENTIAL, IN NEGATIVE KILOPASCALS

Figure 18.--Water-potential profile for borehole UZ-N86 located on an exposed bedrock channel compared to a profile from borehole UZ-N88 located on exposed bedrock on an adjacent hill slope. 


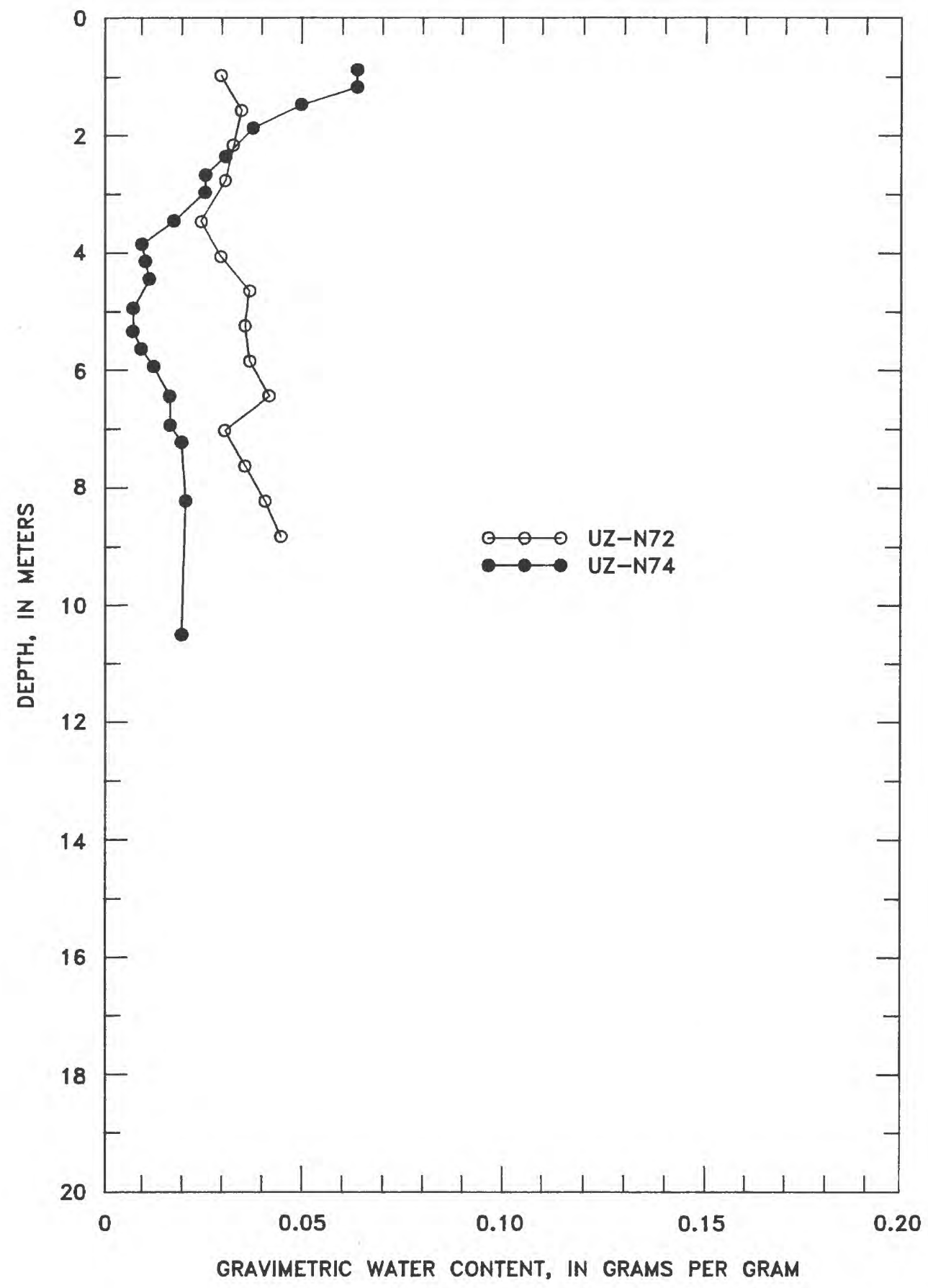

Figure 19.--Water-content profile for borehole UZ-N72 located on an exposed bedrock channel compared to a profile from borehole UZ-N74 located on exposed bedrock on an adjacent hill slope. 


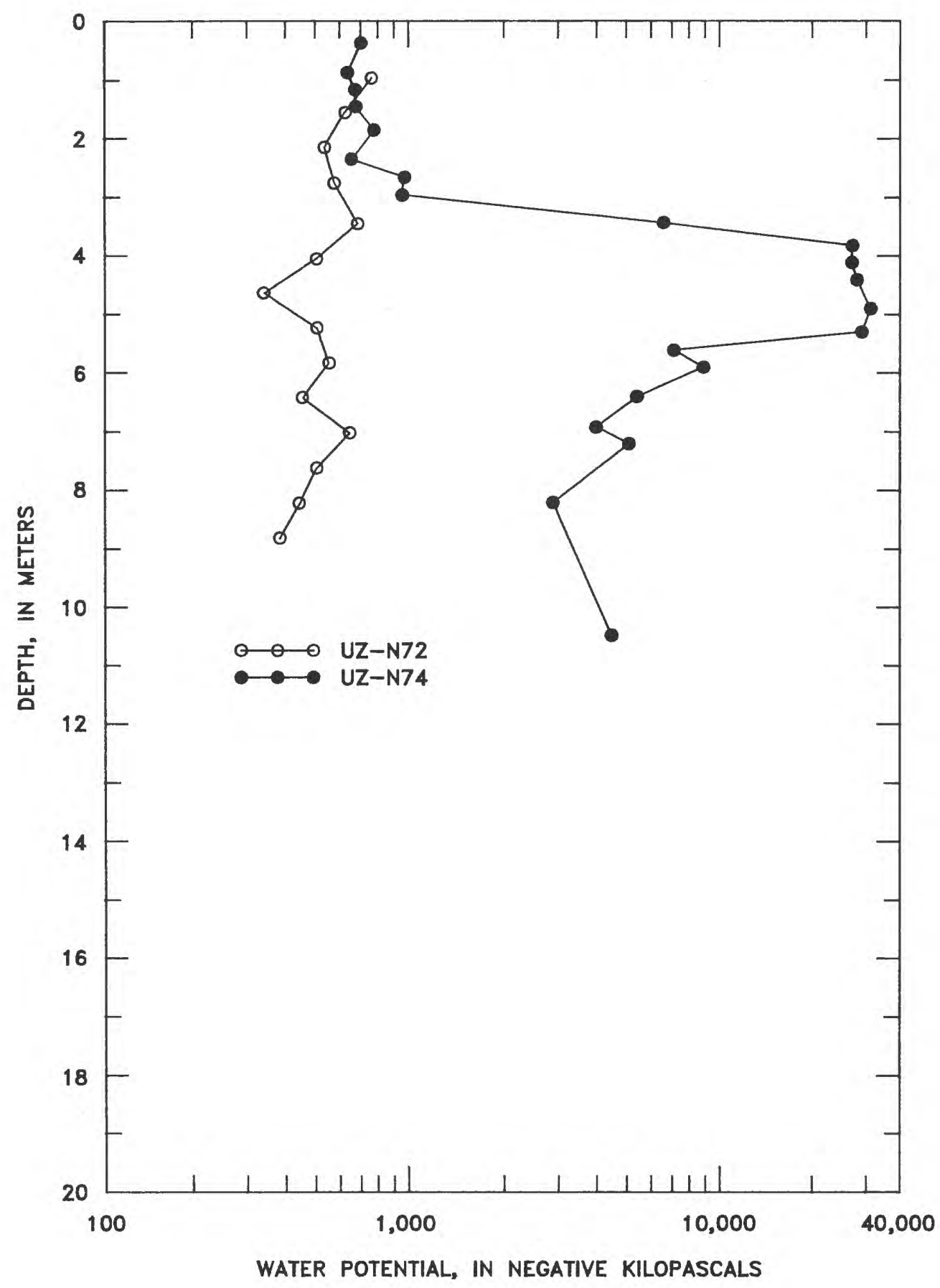

Figure 20.--Water-potential profile for borehole UZ-N72 located on an exposed bedrock channel compared to a profile from borehole UZ-N74 located on exposed bedrock on an adjacent hill slope. 
mermeister and others, 1986). Briefly, these authors reported that the drive-core method alters the porosity and related properties of samples from in-situ conditions.

The effect of welding and lithology on the limited porosity and bulk-density data is shown in table 16 in the "Supplemental Data" section at the back of the report. Nonwelded tuffs have a greater median porosity and smaller bulk density than moderately welded tuffs. In addition, bedded tuffs have a greater median porosity and smaller bulk density than nonwelded tuffs. Grain-density values are relatively constant for all rock units (table 15).

\section{Tritium Analyses}

Tritium concentrations were measured on drivecore samples from selected neutron-access boreholes located in the major channels of several canyons on Yucca Mountain (table 17 in the "Supplemental Data" section at the back of the report) and profiles are shown in figure 21. These tritium data are only the first part of a comprehensive tritium-analysis program designed to help characterize natural-infiltration quantities and processes on Yucca Mountain. Additional tritium analyses are planned for samples from holes that encompass the range of hydrogeologic conditions that occur on Yucca Mountain.

Large quantities of tritium were released into the atmosphere during the period of large-scale thermonuclear atmospheric-bomb testing from 1952 to 1962 (Fritz and Fontes, 1980, p. 22). As a result of precipitation, some of this tritium has entered into the surficial materials covering Yucca Mountain. The addition of bomb-produced tritium to water in the unsaturated zone has resulted in increased tritium concentrations above background levels. Tritium concentrations greater than approximately 5 tritium units (one atom of tritium in $10^{18}$ atoms of hydrogen) are considered to be in excess of natural background levels (Fritz and Fontes, 1980 , p. 22). The enhanced concentration of tritium in water samples makes tritium an excellent environmental tracer (Freeze and Cherry, 1979).

Average net water-flow velocity rates can be estimated from profiles of tritium concentrations versus depth, by analyzing samples for tritium concentrations. The maximum depth reached by tritium concentrations above background levels is estimated from the profiles. This depth then is divided by the time elapsed from the midpoint in the period of above-ground atmospheric testing (approximately $30 \mathrm{yr}$ ). This quotient is a mean net flow velocity for approximately the last $30 \mathrm{yr}$.
Preliminary results (table 17, fig. 21) indicate that increased tritium concentrations decrease to background levels before bedrock-contact depths in boreholes UZN \#8 and UZ-N90 (12.19 m and $9.91 \mathrm{~m}$, respectively). However, increased tritium concentrations do not decrease to background levels before the bedrock contact in UZN \#1 $(8.32 \mathrm{~m})$.

Borehole UZ-N90 is in a channel that transported a large volume of water from aquifer tests made in USW H-6 (Craig and Reed, 1983). Infiltration of this pump-test water may have influenced the tritium concentrations in the profile.

Preliminary flow-velocity data indicate that mean downward flow velocity rates ranged from $0.10 \mathrm{~mm}$ to greater than $0.26 \mathrm{~mm}$ per year, depending upon borehole location. Additional testing will be needed to characterize more accurately the range in mean flow velocity rates in alluvium/colluvium and other rock units.

\section{SUMMARY AND CONCLUSIONS}

Gravimetric water-content and water-potential values of core were generally larger than those of cuttings obtained from the same depth. Reasonable correlations were determined for those hydrologic characteristics between core and cuttings; the only exceptions were water-potential values from nonwelded and bedded tuffs.

Gravimetric water-content and water-potential values of geologic samples tended to decrease as the degree of welding increased. Values were largest for nonwelded to partially welded and bedded tuffs, smaller in moderately welded tuffs, and smallest in densely welded tuffs. Values for alluvium/colluvium often were similar to those determined for moderately welded tuffs.

Bulk-density values increased, porosity values decreased, and grain-density values remained nearly constant as the degree of welding increased from nonwelded to moderately welded tuffs in the boreholes selected for these measurements.

Water-content and water-potential profiles from closely spaced boreholes that penetrated the same lithologic subunit often indicated a substantial degree of spatial variability. Differences in both types of profiles also occurred in adjacent boreholes located in different topographic positions. The vertical-spatial variability of water-content and water-potential data within a thick lithologic unit was very small. Finally, the values of these data tended to decrease near the bottom of welded tuff lithologic units located near the ground surface. 


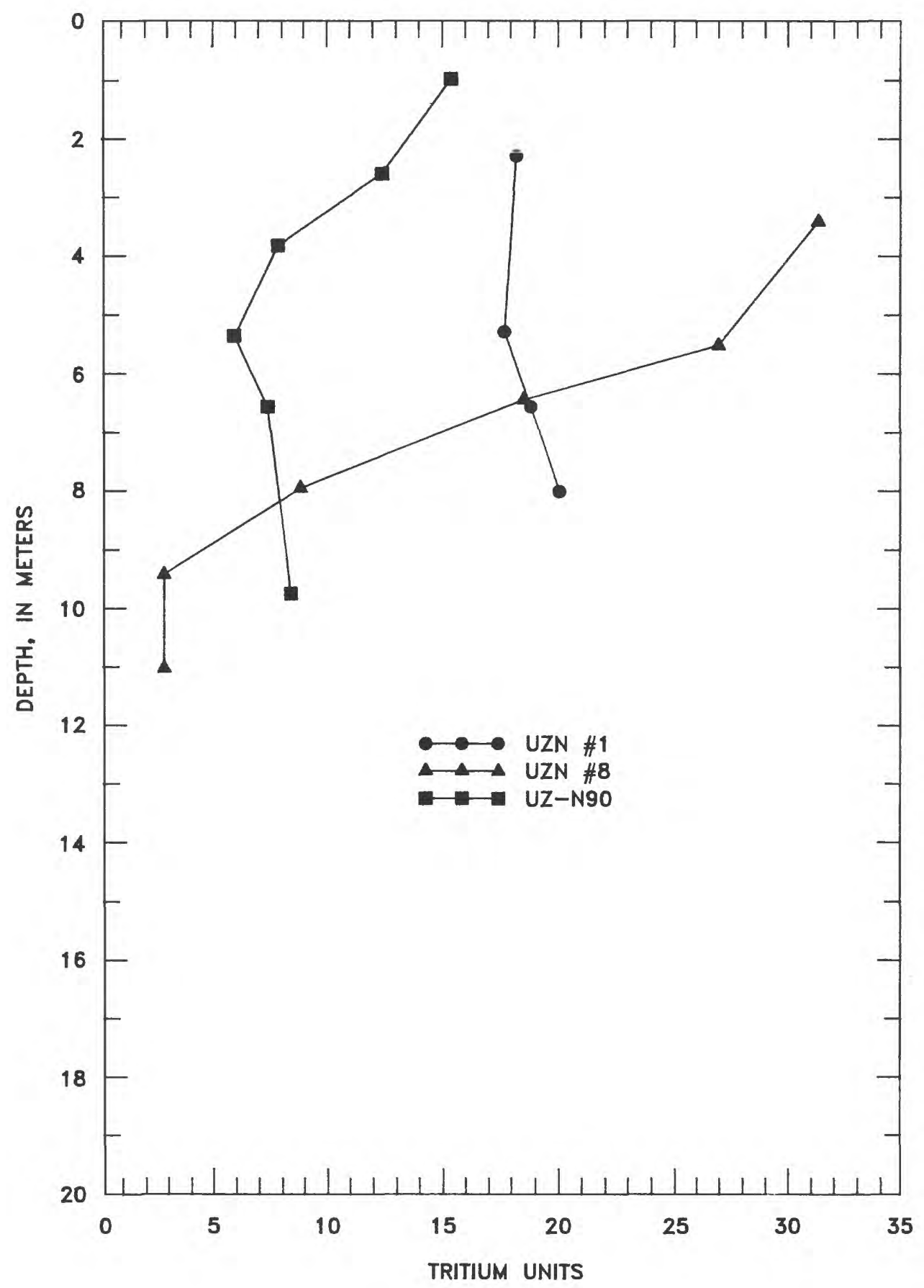

Figure 21.--Tritium profiles for selected neutron-access boreholes. 


\section{REFERENCES CITED}

Bentley, C.B., Robison, J.H., and Spengler, R.W., 1983, Geohydrologic data for test well USW H-5, Yucca Mountain area, Nye County, Nevada: U.S. Geological Survey Open-File Report 83-853, 34 p. (NNA.8705190.0098)

Craig, R.W., Reed, R.L., and Spengler, R.W., 1983, Geohydrologic data for test well USW H-6, Yucca Mountain Area, Nye County, Nevada: U.S. Geological Survey Open-File Report 83-856, 35 p. (NNA.870406.0058)

Fenix \& Scisson, Inc., 1987, NNWSI hole histories-Unsaturated zone - Neutron Holes- 76 boreholes drilled between May 1984 and February 1986: Mercury, Nevada, DOE/NV/10322-21, 310 p. (NNA.900208.0106)

Freeze, R.A., and Cherry, J.A., 1979, Groundwater: Englewood Cliffs, N.J., Prentice-Hall, 588 p. (NNA.870406.0444)

Fritz, P., and Fontes, J. Ch., 1980, eds., Handbook of Environmental Isotope Geochemistry, The Terrestrial Environment: Amsterdam, Elsevier, v. 1A, p. 22. (NNA.940617.0041)

Gardner, W.H., 1986, Water content in Klute, A., ed., Methods of soil analysis-Part 1, Physical and mineralogical methods (2d ed.): Madison, Wis., American Society of Agronomy, (Agronomy Series no. 9), p. 493-544. (NNA.900208.0104)

Hald, A., 1952, Statistical theory with engineering applications, New York, Wiley, 420 p. (NNA.900227.0042)

Hammermeister, D.P., Blout, D.O., and McDaniel, J.C., 1986, Drilling and coring methods to minimize the disturbance of cuttings, core, and rock formations in the unsaturated zone, Yucca Mountain, Nevada, in Characterization and Monitoring of the Vadose (Unsaturated) Zone Conference, Denver, 1985, Proceedings: Worthington, Ohio, National Water Well Association, p. 507-541. (HQS.880517.2696)

Journel, A.G., and Huijbregts, Ch.J., 1978, Mining geostatistics: London, England, Academic Press, 600 p. (NNA.900103.0186)

Montazer, Parviz, and Wilson, W.E., 1984, Conceptual hydrologic model of flow in the unsaturated zone, Yucca Mountain, Nevada: U.S. Geological Survey Water-Resources Investigations Report 84-4345, 55 p. (NNA.870519.0109)

Rawlins, S.L., and Campbell, G.S., 1986, Water Potential: Thermocouple Psychrometry, in Klute, A., ed., Methods of soil analysis, Part I, Physical and mineralogical methods (2d ed.): Madison, Wis., American Society of Agronomy (Agronomy Series no. 9), p. 597-618. (NNA.900227.0044)
Roseboom, E.H., Jr., 1983, Disposal of high-level nuclear waste above the water table in arid regions: U.r. Geological Survey Circular 903, 21 p. (NNA.870824.0061)

Scott, R.B., and Bonk, Jerry, 1984, Preliminary geologic map of Yucca Mountain, Nye County, Nevada, with geologic sections: U.S. Geological Survey Open-File Report 84-494, 10 p. (HQS.880517.1443)

Scott, R.B., Spengler, R.W., Diehl, Sharon, Lappin, A.R., and Chornack, M.P., 1983, in Mercer, J.W., ed., Pole of the unsaturated zone in radioactive and hazardo's waste disposal: Ann Arbor, Mich., Ann Arbor Srience Publications, p. 289-335. (NNA.870406.0034)

Squires, R.R., and Young, R.L., 1984, Flood potential of Fortymile Wash and its principal southwestern tributaries, Nevada Test Site, southern Nevada: U.S. Geological Survey Water-Resources Investigations Report 83-4001, 33 p. (NNA.890511.0110)

Thordarson, William, Rush, F.E., Spengler, R.W., and Waddell, S.J., 1984, Geohydrologic and drill-hole data for test well USW H-3, Yucca Mountain, Nye County, Nevada: U.S. Geological Survey Open-File Report 84-149, 54 p. (NNA.870406.0056)

Waddell, R.K., 1982, Two-dimensional, steady-state model of ground-water flow, Nevada Test Site and vicinity, Nevada-California: U.S. Geological Survey WaterResources Investigations Report 82-4085, 72 p. (NNA.870518.0055)

Waddell, R.K., Robison, J.H., and Blankennagel, R.K., 1984, Hydrology of Yucca Mountain and vicinit: Nevada-California-Investigative results through mid1983: U.S. Geological Survey Water-Resources Investigations Report 84-4267, 72 p. (NNA.870406.(343)

NOTE: Parenthesized numbers following cited reference are for OCRWM Records Management purjoses only and should not be used when ordering the prblication. 


\section{SUPPLEMENTAL DATA}


Table 1. Location, depth, and hydrogeologic setting of the neutron-access boreholes

[The neutron-access borehole number prefix UE-25 or UE-29 indicates the borehole is located on the Nevada Test Site, the USW prefix is for boreholes located off the Nevada Test Site; the coordinates are the Nevada Coordinate System. Central Zone]

\begin{tabular}{|c|c|c|c|c|c|c|}
\hline \multirow{2}{*}{$\begin{array}{l}\text { Neutron- } \\
\text { access } \\
\text { borehole } \\
\text { number }\end{array}$} & \multirow[t]{2}{*}{$\begin{array}{l}\text { Borehole } \\
\text { location }\end{array}$} & $\begin{array}{l}\text { Ground } \\
\text { elevation }\end{array}$ & $\begin{array}{l}\text { Borehole } \\
\text { depth }\end{array}$ & $\begin{array}{c}\text { Tuff/ } \\
\text { alluvium } \\
\text { contact }\end{array}$ & \multirow[t]{2}{*}{$\begin{array}{l}\text { Preliminary hydrogoologic } \\
\text { surficial unit }\end{array}$} & \multirow[t]{2}{*}{ Topographic position } \\
\hline & & (meters) & (meters) & (meters) & & \\
\hline UE-25 & N 234,494 & 1,218 & 15.24 & 8.32 & Alluvium/colluvium & Large channel bottom \\
\hline UZN \#1 & E 172,282 & & & & & \\
\hline UE-25 & N 234,274 & 1,203 & 15.24 & 0.0 & Tiva Canyon hackly & Canyon wall \\
\hline UZN \#2 & E 172,554 & & & & & \\
\hline UE-25 & N 234,281 & 1,201 & 4.57 & 2.74 & Alluvium/colluvium & Terrace \\
\hline UZN \#3 & E 172,555 & & & & & \\
\hline UE-25 & N 234,291 & 1,202 & 9.14 & 7.47 & Alluvium/colluvium & Terrace \\
\hline UZN \#4 & E 172,558 & & & & & \\
\hline UE-25 & N 234,229 & 1,201 & 15.24 & 13.56 & Alluvium/colluvium & Terrace \\
\hline UZN \#5 & E 172,560 & & & & & \\
\hline UE-25 & N 234,304 & 1,200 & 13.72 & 12.04 & Alluvium/colluvium & Large channel bottom \\
\hline UZN \#6 & E 172,561 & & & & & \\
\hline UE-25 & N 234,310 & 1,201 & 13.72 & 12.34 & Alluvium/colluvium & Large channel bottom \\
\hline UZN \#7 & E 172,562 & & & & & \\
\hline UE-25 & N 234,316 & 1,201 & 13.72 & 12.19 & Alluvium/colluvium & Large channel bottom \\
\hline UZN \#8 & E 172,564 & & & & & \\
\hline UE-25 & N 234,328 & 1,201 & 12.19 & 10.67 & Alluvium/colluvium & Terrace \\
\hline UZN \#9 & E 172,566 & & & & & \\
\hline UE-25 & N 234,659 & 1,231 & 30.18 & .0 & Nonwelded and bedded tuff & Large channel bottom \\
\hline UZN \#10 & E 172,136 & & & & & \\
\hline UE-25 & N 234,288 & 1,191 & 15.24 & 13.72 & Alluvium/colluvium & Large channel bottom \\
\hline $\mathrm{UZN} \# 12$ & E172,731 & & & & & \\
\hline UE-25 & N 234,097 & 1,165 & 19.81 & 13.41 & Alluvium/colluvium & Large channel bottom \\
\hline $\mathrm{UZN} \# 13$ & E 173,206 & & & & & \\
\hline UE-25 & N 234,079 & 1,166 & 16.76 & 13.41 & Alluvium/colluvium & Terrace \\
\hline UZN \#14 & E 173,200 & & & & & \\
\hline
\end{tabular}


Table 1. Location, depth, and hydrogeologic setting of the neutron-access boreholes--Continued

\begin{tabular}{|c|c|c|c|c|c|c|}
\hline \multirow[t]{2}{*}{$\begin{array}{c}\text { Neutron- } \\
\text { access } \\
\text { borehole } \\
\text { number }\end{array}$} & \multirow[t]{2}{*}{$\begin{array}{l}\text { Borehole } \\
\text { location }\end{array}$} & $\begin{array}{l}\text { Ground } \\
\text { elevatlon }\end{array}$ & $\begin{array}{l}\text { Borehole } \\
\text { depth }\end{array}$ & $\begin{array}{c}\text { Tuff/ } \\
\text { alluvium } \\
\text { contact }\end{array}$ & \multirow[t]{2}{*}{$\begin{array}{c}\text { Preliminary hydrogeologic } \\
\text { surficial unit }\end{array}$} & \multirow[t]{2}{*}{ Topographle posi "'n } \\
\hline & & (meters) & (meters) & (meters) & & \\
\hline UE-25 & N 233,624 & 1,225 & 18.59 & 17.07 & Alluvium/colluvium & Large channel bottom \\
\hline UZN \#18 & E 172,289 & & & & & \\
\hline UE-25 & $\mathrm{N} 232,775$ & 1,227 & 12.19 & 6.86 & Alluvium/colluvium & Large channel bottom \\
\hline UZN \#19 & E 172,083 & & & & & \\
\hline UE-25 & N 232,797 & 1,227 & 12.50 & 11.89 & Alluvium/colluvium & Braided channel \\
\hline $\mathrm{UZN} \# 20$ & E 172,086 & & & & & \\
\hline UE-25 & $\mathrm{N} 232,811$ & 1,228 & 12.80 & 8.38 & Alluvium/colluvium & Braided channel \\
\hline $\mathrm{UZN} \# 21$ & E 172,089 & & & & & \\
\hline UE-25 & N 232,833 & 1,228 & 28.96 & 5.94 & Alluvium/colluvium & Braided channel \\
\hline $\mathrm{UZN} \# 22$ & E 172,094 & & & & & \\
\hline UE-25 & N 232,862 & 1,232 & 10.67 & .0 & Tiva Canyon lower lithophysal & Canyon wall lower slope \\
\hline $\mathrm{UZN} \# 23$ & E 172,075 & & & & & \\
\hline USW & N 234,091 & 1,288 & 22.86 & .15 & Alluvium/colluvium & Channel bottom \\
\hline UZ-N24 & E 171,316 & & & & & \\
\hline USW & N 234,220 & 1,321 & 17.98 & .0 & Tiva Canyon hackly & Channel bottom \\
\hline UZ-N25 & E 171,062 & & & & & \\
\hline USW & N 234,320 & 1,336 & 10.67 & .0 & Tiva Canyon lower lithophysal & Channel bottom \\
\hline UZ-N26 & E 171,002 & & & & & \\
\hline UE-25 & N 232,593 & 1,206 & 8.08 & $?$ & Alluvium/colluvium & Braided channel \\
\hline $\mathrm{UZN} \# 28$ & E 172,312 & & & & & \\
\hline UE-25 & N 232,447 & 1,211 & 10.67 & .30 & Alluvium/colluvium & Canyon wall lower slcne \\
\hline UZN \#29 & E 172,267 & & & & & \\
\hline UE-25 & $N 232,275$ & 1,207 & 10.67 & .38 & Alluvium/colluvium & Canyon wall lower slcne \\
\hline UZN \#30 & E 172,285 & & & & & \\
\hline USW & $\mathrm{N} 233,533$ & 1,243 & 10.67 & .88 & Alluvium/colluvium & Lower slope \\
\hline UZ-N40 & E 171,977 & & & & & \\
\hline USW & N 233,439 & 1,255 & 11.28 & 4.88 & Alluvium/colluvium & Channel bottom \\
\hline UZ-N41 & E 171,763 & & & & & \\
\hline
\end{tabular}


Table 1. Location, depth, and hydrogeologic setting of the neutron-access boreholes--Continued

\begin{tabular}{|c|c|c|c|c|c|c|}
\hline \multirow{2}{*}{$\begin{array}{l}\text { Neutron- } \\
\text { access } \\
\text { borehole } \\
\text { number }\end{array}$} & \multirow[t]{2}{*}{$\begin{array}{l}\text { Borehole } \\
\text { location }\end{array}$} & \multirow{2}{*}{$\begin{array}{c}\begin{array}{c}\text { Ground } \\
\text { elevation }\end{array} \\
\text { (meters) }\end{array}$} & \multirow{2}{*}{$\begin{array}{c}\begin{array}{c}\text { Borehole } \\
\text { depth }\end{array} \\
\text { (meters) }\end{array}$} & \multirow{2}{*}{$\begin{array}{c}\begin{array}{c}\text { Tuft/ } \\
\text { alluvium } \\
\text { contact }\end{array} \\
\text { (meters) }\end{array}$} & \multirow[t]{2}{*}{$\begin{array}{l}\text { Preliminary hydrogeologic } \\
\text { surficlal unit }\end{array}$} & \multirow[t]{2}{*}{ Topographic position } \\
\hline & & & & & & \\
\hline USW & N 233,397 & 1,274 & 12.19 & 0.0 & Tiva Canyon lower lithophysal & Channel botto $n$ \\
\hline UZ-N42 & E 171,561 & & & & & \\
\hline USW & N 233,479 & 1,265 & 13.72 & 8.23 & Alluvium/colluvium & Terrace \\
\hline UZ-N43 & E 171,685 & & & & & \\
\hline USW & N 233,538 & 1,269 & 10.97 & .0 & Tiva Canyon lower lithophysal & Channel botton \\
\hline UZ-N44 & E 171,647 & & & & & \\
\hline USW & N 233,473 & 1,259 & 13.72 & 10.67 & Alluvium/colluvium & Channel botton \\
\hline UZ-N45 & E 171,735 & & & & & \\
\hline USW & N 235,388 & 1,372 & 30.18 & .0 & Nonwelded and bedded tuffs & Large channel bottom \\
\hline UZ-N46 & E 170,613 & & & & & \\
\hline USW & $\mathrm{N} 235,301$ & 1,366 & 26.21 & 10.06 & Alluvium/colluvium & Large channel bottom \\
\hline UZ-N47 & E 170,624 & & & & & \\
\hline USW & N 231,905 & 1,284 & 10.67 & .0 & Tiva Canyon hackly & Channel bottom \\
\hline UZ-N48 & E 171,426 & & & & & \\
\hline USW & N 231,913 & 1,289 & 10.97 & .61 & Alluvium/colluvium & Canyon wall \\
\hline UZ-N49 & E 171,398 & & & & & \\
\hline USW & N 231,887 & 1,272 & 6.10 & 2.74 & Alluvium/colluvium & Terrace \\
\hline UZ-N50 & E 171,578 & & & & & \\
\hline USW & N 231,913 & 1,271 & 6.10 & 4.27 & Alluvium/colluvium & Channel bottom \\
\hline UZ-N51 & E 171,577 & & & & & \\
\hline USW & N 231,923 & 1,272 & 7.62 & 2.13 & Alluvium/colluvium & Terrace \\
\hline UZ-N52 & E 171,577 & & & & & \\
\hline UE-25 & N 231,771 & 1,207 & 18.29 & 17.07 & Alluvium/colluvium & Channel bottom \\
\hline UZN \#56 & E 172,360 & & & & & \\
\hline UE-25 & N 231,577 & 1,186 & 10.67 & 8.08 & Alluvium/colluvium & Channel bottom \\
\hline UZN \#60 & E 172,692 & & & & & \\
\hline USW & N 231,232 & 1,333 & 15.24 & .0 & Tiva Canyon upper cliff & Mid-ridge slofe \\
\hline UZ-N65 & E 171,463 & & & & & \\
\hline
\end{tabular}


Table 1. Location, depth, and hydrogeologic setting of the neutron-access boreholes--Continued

\begin{tabular}{|c|c|c|c|c|c|c|}
\hline \multirow{2}{*}{$\begin{array}{l}\text { Neutron- } \\
\text { access } \\
\text { borehole } \\
\text { number }\end{array}$} & \multirow[t]{2}{*}{$\begin{array}{l}\text { Borehole } \\
\text { location }\end{array}$} & $\begin{array}{l}\text { Ground } \\
\text { elevation }\end{array}$ & $\begin{array}{l}\text { Borehole } \\
\text { depth }\end{array}$ & $\begin{array}{c}\text { Tuff/ } \\
\text { alluvium } \\
\text { contact }\end{array}$ & \multirow[t]{2}{*}{$\begin{array}{c}\text { Preliminary hydrogeologic } \\
\text { surficial unit }\end{array}$} & \multirow[t]{2}{*}{ Topographic post ion } \\
\hline & & (meters) & (meters) & (meters) & & \\
\hline USW & $\mathrm{N} 231,173$ & 1,328 & 15.24 & 0.0 & Tiva Canyon clinkstone & Mid-ridge slope \\
\hline UZ-N66 & E 171,263 & & & & & \\
\hline USW & N 229,710 & 1,195 & 7.62 & 5.79 & Alluvium/colluvium & Channel bottom \\
\hline UZ-N67 & E 171,848 & & & & & \\
\hline USW & N 229,810 & 1,196 & 16.76 & 15.24 & Alluvium/colluvium & Braided channel \\
\hline UZ-N68 & E 171,911 & & & & & \\
\hline USW & N 229,963 & 1,194 & 10.67 & 8.23 & Alluvium/colluvium & Channel bottom \\
\hline UZ-N69 & E 172,032 & & & & & \\
\hline USW & N 234,471 & 1,384 & 10.67 & .0 & Tiva Canyon lower lithophysal & Channel bottom \\
\hline UZ-N70 & E 170,740 & & & & & \\
\hline USW & N 231,964 & 1,501 & 15.85 & .0 & Tiva Canyon caprock & Upper ridge \\
\hline UZ-N71 & E 170,204 & & & & & \\
\hline USW & N 231,976 & 1,490 & 9.14 & .0 & Tiva Canyon upper cliff & Upland channel bottom \\
\hline UZ-N72 & E 170,271 & & & & & \\
\hline USW & N 231,971 & 1,483 & 9.14 & .0 & Tiva Canyon upper lithophysal & Upland channel bottom \\
\hline UZ-N73 & E 170,363 & & & & & \\
\hline USW & $\mathrm{N} 232,066$ & 1,495 & 11.28 & .0 & Tiva Canyon caprock & Upper ridge \\
\hline UZ-N74 & E 170,251 & & & & & \\
\hline USW & N 232,096 & 1,463 & 11.28 & .61 & Alluvium/colluvium & Upper ridge \\
\hline UZ-N75 & E 170,408 & & & & & \\
\hline USW & N 232,063 & 1,511 & 12.19 & .0 & Tiva Canyon upper cliff & Upper ridge \\
\hline UZ-N76 & E 170,400 & & & & & \\
\hline USW & N 230,287 & 1,189 & 15.24 & 11.58 & Alluvium/colluvium & Large channel bottom \\
\hline UZ-N77 & E 168,982 & & & & & \\
\hline USW & N 230,906 & 1,275 & 9.14 & .0 & Tiva Canyon caprock & Canyon wall \\
\hline UZ-N78 & E 169,551 & & & & & \\
\hline USW & N 230,960 & 1,266 & 9.75 & .0 & Tiva Canyon upper lithophysal & Channel bottom \\
\hline UZ-N79 & E 169,573 & & & & & \\
\hline
\end{tabular}


Table 1. Location, depth, and hydrogeologic setting of the neutron-access boreholes--Continued

\begin{tabular}{|c|c|c|c|c|c|c|}
\hline \multirow{2}{*}{$\begin{array}{c}\text { Neutron- } \\
\text { access } \\
\text { borehole } \\
\text { number }\end{array}$} & \multirow[t]{2}{*}{$\begin{array}{l}\text { Borehole } \\
\text { location }\end{array}$} & $\begin{array}{l}\text { Ground } \\
\text { elevation }\end{array}$ & $\begin{array}{l}\text { Borehole } \\
\text { depth }\end{array}$ & $\begin{array}{c}\text { Tuff/ } \\
\text { alluvium } \\
\text { contact }\end{array}$ & \multirow[t]{2}{*}{$\begin{array}{c}\text { Preliminary hydrogeologic } \\
\text { surficial unit }\end{array}$} & \multirow[t]{2}{*}{ Topograph'^ position } \\
\hline & & (meters) & (meters) & (meters) & & \\
\hline USW & N 230,930 & 1,320 & 15.85 & 0.0 & Topopah Spring brick & Upland channel bottom \\
\hline UZ-N80 & E 169,837 & & & & & \\
\hline USW & N 230,982 & 1,239 & 21.34 & 1.83 & Alluvium/colluvium & Channel bottom \\
\hline UZ-N81 & E 169,347 & & & & & \\
\hline USW & N 230,888 & 1,212 & 12.19 & 6.70 & Alluvium/colluvium & Large channel \\
\hline UZ-N82 & E 169,072 & & & & & \\
\hline USW & N 231,841 & 1,267 & 21.34 & .0 & Tiva Canyon clinkstone & Small channel bottom \\
\hline UZ-N83 & E 169,577 & & & & & \\
\hline USW & N 231,869 & 1,253 & 13.72 & 6.09 & Alluvium/colluvium & Terrace \\
\hline UZ-N84 & E 169,437 & & & & & \\
\hline UE-25 & N 228,821 & 1,017 & 24.38 & $?$ & Alluvium/colluvium & Terrace \\
\hline UZN \#85 & E 176,045 & & & & & \\
\hline USW & N 231,838 & 1,272 & 9.14 & .0 & Tiva Canyon clinkstone & Small channel bottom \\
\hline UZ-N86 & E 169,611 & & & & & \\
\hline USW & N 231,868 & 1,253 & 13.72 & 5.79 & Alluvium/colluvium & Terrace \\
\hline UZ-N87 & E 169,436 & & & & & \\
\hline USW & N 231,894 & 1,281 & 9.14 & .23 & Alluvium/colluvium & Canyon wall \\
\hline UZ-N88 & E 169,639 & & & & & \\
\hline USW & N 231,837 & 1,247 & 13.72 & 10.06 & Alluvium/colluvium & Large channel bottom \\
\hline UZ-N89 & E 169,346 & & & & & \\
\hline USW & N 231,836 & 1,247 & 13.72 & 9.91 & Alluvium/colluvium & Large channel bottom \\
\hline UZ-N90 & E 169,345 & & & & & \\
\hline UE-29 & N 243,012 & 1,112 & 28.65 & 19.51 & Alluvium/colluvium & Large channel bottom \\
\hline UZN \#91 & E 178,414 & & & & & \\
\hline UE-25 & $\mathrm{N} 237,140$ & 1,118 & 36.58 & 17.68 & Alluvium/colluvium & Large channel bottom \\
\hline UZN \#92 & $\mathrm{E} 177,871$ & & & & & \\
\hline USW & N 231,524 & 1,501 & 12.19 & .0 & Tiva Canyon caprock & Disturbed area \\
\hline UZ-N93 & E 170,178 & & & & & \\
\hline
\end{tabular}


Table 1. Location, depth, and hydrogeologic setting of the neutron-access boreholes--Continued

\begin{tabular}{|c|c|c|c|c|c|c|}
\hline $\begin{array}{c}\text { Neutron- } \\
\text { access } \\
\text { borehole } \\
\text { number }\end{array}$ & $\begin{array}{l}\text { Borehole } \\
\text { location }\end{array}$ & $\begin{array}{c}\text { Ground } \\
\text { elevation }\end{array}$ & $\begin{array}{c}\begin{array}{c}\text { Borehole } \\
\text { depth }\end{array} \\
\text { (meters) }\end{array}$ & $\begin{array}{c}\begin{array}{c}\text { Tuff/ } \\
\text { alluvium } \\
\text { contact }\end{array} \\
\text { (meters) }\end{array}$ & $\begin{array}{c}\text { Preliminary hydrogeologic } \\
\text { surficial unit }\end{array}$ & Topographic position \\
\hline$\overline{\text { USW }}$ & $\mathrm{N} 231,567$ & 1,501 & 9.14 & 0.0 & Tiva Canyon caprock & Disturbed area \\
\hline UZ-N94 & E 170,152 & & & & & \\
\hline USW & N 231,620 & 1,502 & 6.10 & .0 & Tiva Canyon caprock & Disturbed area \\
\hline UZ-N95 & E 170,133 & & & & & \\
\hline USW & N 231,482 & 1,491 & 10.67 & .61 & Alluvium/colluvium & Upper ridge \\
\hline UZ-N96 & E 170,203 & & & & & \\
\hline UE-25 & $\mathrm{N} 232,594$ & 1,206 & 18.29 & 17.68 & Alluvium/colluvium & Braided channel \\
\hline UZN \#97 & E 172,312 & & & & & \\
\hline USW & N 234,087 & 1,287 & 22.86 & .30 & Alluvium/colluvium & Channel bottom \\
\hline UZ-N98 & E 171,325 & & & & & \\
\hline
\end{tabular}

Table 2. Estimates of the relative area and selected properties of the preliminary hydrogeologic-surficial units

\begin{tabular}{|c|c|c|c|c|}
\hline $\begin{array}{c}\text { Preliminary hydrogeologic } \\
\text { surficial unit }\end{array}$ & $\begin{array}{c}\text { Percent } \\
\text { area of } \\
\text { study } \\
\text { area }\end{array}$ & Relative degree of welding & $\begin{array}{l}\text { Relative number and } \\
\text { size of lithophysal } \\
\text { cavities }\end{array}$ & $\begin{array}{l}\text { Relative degren of } \\
\text { fracturing }\end{array}$ \\
\hline Alluvium/colluvium & 10 & Not applicable & Not applicable & Rare \\
\hline $\begin{array}{l}\text { Paintbrush Tuff } \\
\text { nonwelded and bedded tuffs }\end{array}$ & 3 & Nonwelded & Not applicable & Low \\
\hline $\begin{array}{l}\text { Tiva Canyon Member } \\
\text { caprock-upper cliff }\end{array}$ & 25 & Moderately to densely welded & Few to many/large & Moderate \\
\hline Upper lithophysal & 20 & Moderately to densely welded & Many/large & Low to moderate \\
\hline Clinkstone & 25 & Densely welded & None & High \\
\hline Lower lithophysal & 10 & Densely welded & Many/small & Low to moderate \\
\hline Hackly-columnar & 5 & Densely welded & Rare to few/small & Moderate to high \\
\hline $\begin{array}{l}\text { Topopah Spring Member } \\
\text { upper units }\end{array}$ & 2 & Partially to moderately welded & Few/small & Moderate to high \\
\hline
\end{tabular}


Table 3. Lithologic logs of the neutron-access boreholes at Yucca Mountain

Stratigraphic and IIthologic description
Borehole number UE-25 UZN \#1
Alluvium and colluvium, consisting of silt-sized to gravel-sized, subrounded to subangular,
moderately to densely welded ash-flow tuff. Secondary carbonate coatings and discolora
tion present. Fresh surfaces on some fragments indicate they were chipped from larger
pieces.
Paintbrush Tuff
Bedded Tuff
Tuff, bedded, white and light-brown, poorly indurated, vitric; pumice, white, vitric; phe-
nocrysts, sanidine, and plagioclase; rhyolitic-lithic fragments; clear glass shards. No
cuttings from 7.92 to 10.97 meters. Cuttings from 10.97 to 11.28 meters very fine.
Contact from well-site log book.

Yucca Mountain Member

Tuff, ash-flow, very light gray to light-gray, nonwelded, vitric; pumice, grayish-orange-pink to moderate-orange-pink, vitric; phenocrysts, sanidine and plagioclase; abundant clear glass shards.

\section{Borehole number UE-25 UZN \#2}

Paintbrush Tuff

Tiva Canyon Member

Tuff (hackly), ash-flow, grayish-red with moderate-orange-pink halos surrounding some phenocrysts, moderately to densely welded, devitrified; pumice, medium-light-gray, devitrified; phenocrysts, 5 percent, sanidine, and plagioclase; rare medium-dark-gray rhyolitic-lithic fragments.

Tuff (columnar), ash-flow, dark-reddish-brown to pale-reddish-brown, moderately to densely welded, partially vitric; pumice, dark-reddish-brown, devitrified, flattened 3:1; phenocrysts, 3 to 5 percent, sanidine and plagioclase; manganese oxide dendrites in matrix; occasional gray-ish-red rhyolitic-lithic fragments.

Borehole number UE-25 UZN \#3

Alluvium and colluvium, consisting of silt-sized to pebble-gravel-sized, poorly sorted, subangular to subrounded, light-gray to medium-gray, moderately welded tuffs of the Tiva Canyon Member. The silt-sized portion is light-brown, consisting of tuffs and free phenocrysts. Some fragments with secondary carbonate coatings.

Paintbrush Tuff

Tiva Canyon Member

Tuff (hackly), ash-flow, grayish-red to pale-red, densely welded, devitrified; pumice, medium-light-gray, devitrified; phenocrysts, 3 to 5 percent sanidine and plagioclase.

\section{Borehole number UE-25 UZN \#4}

Alluvium and colluvium, consisting of silt-sized to pebble-gravel-sized, poorly sorted, angular to rounded, light-gray, yellowish-gray, light-brown and grayish-red, partially to densely welded tuffs. Free sanidine, plagioclase and bronze biotite. Some secondary carbonate coatings on fragments.

\section{Thickness of interval \\ (meters)}

8.32

Total depth

C spth to

bottom of Interval

(neters)

8.32

Total depth 
Table 3. Lithologic logs of the neutron-access boreholes at Yucca Mountain--Continued

Stratigraphic and lithologic description

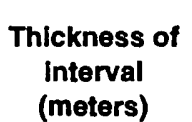

1.06

8.53

Paintbrush Tuff

Tiva Canyon Member

Tuff (hackly), ash-flow, grayish-red and light gray, mottled, densely welded, devitrified; pumice, pale brown to grayish-brown, devitrified; phenocrysts, less than 1 percent; manganese oxide dendrites in matrix and surrounding fragments.

Tuff (columnar), ash-flow, grayish-red, densely welded, devitrified; pumice, dark reddishbrown, devitrified; phenocrysts, 1 to 2 percent, sanidine and plagioclase; occasional moderate reddish brown, streaky coloration of matrix.

\section{Borehole number UE-25 UZN \#5}

Alluvium and colluvium, consisting of silt-sized to pebble-gravel-sized, poorly sorted, subangular to subrounded, light-gray to medium-light-gray and reddish-light-gray, moderately to densely welded tuffs of the Tiva Canyon Member. Some fragments with secondary carbonate coatings.

Paintbrush Tuff

Tiva Canyon Member

Tuff (columnar), ash-flow, grayish-red, densely welded, devitrified; pumice, 2 to 3 percent, dark-reddish-brown, devitrified, flattened $4: 1$; phenocrysts, 3 percent, sanidine and plagioclase; sparse light-gray rhyolitic-lithic fragments.

\section{Borehole number UE-25 UZN \#6}

Alluvium and colluvium, consisting of silt-sized to pebble-gravel-sized, poorly sorted, subangular to subrounded, light-gray to medium-light gray, moderately to densely welded tuff (with minor quantities of nonwelded to partially welded tuffs), mostly Tiva Canyon Member. The silt to fine-sand portion is grayish-orange-pink to light-brown. Some fragments with secondary carbonate coatings.

Paintbrush Tuff

Tiva Canyon Member

Tuff (columnar), ash-flow, moderate-brown, moderately to densely welded, devitrified; pumice, grayish-brown, devitrified; phenocrysts, 3 to 5 percent, sanidine, plagioclase, and biotite; rare grayish-red rhyolitic-lithic fragments.

Borehole number UE-25 UZN \#7

Alluvium and colluvium, consisting of silt-sized to pebble-gravel-sized, poorly sorted, subangular to subrounded, light-gray to medium-light-gray and grayish-red, moderately to densely welded tuffs of the Tiva Canyon Member. Angular fragments were chipped from larger fragments. The silt to fine-sand portion is grayish-orange-pink to lightbrown, consisting of tuff and fragments of free phenocrysts.

Paintbrush Tuff

Tiva Canyon Member

Tuff (columnar), ash-flow, grayish-red to moderate-brown, moderately to densely welded, devitrified; pumice, unable to distinguish in the cuttings; phenocrysts, 3 to 5 percent, sanidine and plagioclase.
Depth to

bottom of interve'

(meter?) 
Table 3. Lithologic logs of the neutron-access boreholes at Yucca Mountain-Continued

\begin{tabular}{lc}
\hline Stratigraphic and llthologic description & $\begin{array}{c}\text { Thickness of } \\
\text { interval } \\
\text { (meters) }\end{array}$ \\
\hline
\end{tabular}

Borehole number UE-25 UZN \#8

Alluvium and colluvium, consisting of silt-sized to pebble-gravel-sized, poorly sorted, sub-

angular to subrounded, light-gray to medium-gray, moderately to densely welded tuffs of the Tiva Canyon Member. The silt to fine-sand portion is light brown, consisting of tuff and fragments of free phenocrysts. The angularity of some of the fragments indicate they were derived from larger pebbles, cobbles or boulders.

Alluvium and colluvium, consisting of predominantly granule-sized (some silt-sized to to densely welded tuff fragments of the Tiva Canyon Member.

Alluvium and colluvium, consisting of silt-sized to pebble-gravel-sized, poorly sorted, subangular to subrounded, light-gray to medium-gray, moderately to densely welded tuffs of the Tiva Canyon Member. The light-brown silt-sized portion consists of tuff and phenocrysts. Angular fragments chipped from larger pebbles or boulders.

Alluvium and colluvium, predominantly silt-sized to granular-sized (some larger fragments), moderately sorted, subangular to subrounded, light-gray and medium-gray, moderately to densely welded tuff fragments.

Paintbrush Tuff

Tiva Canyon Member

Tuff (columnar), ash-flow, pale-red and pale-reddish-brown, moderately welded, devitrified; no pumice seen in the cuttings; phenocrysts; 3 to 5 percent, sanidine and plagioclase; rare grayish-red rhyolitic-lithic fragments.

\section{Borehole number UE-25 UZN \#9}

Total depth

Alluvium and colluvium, consisting of silt-sized to boulder-gravel-sized, subangular to subrounded, moderately to densely welded ash-flow tuffs. Rare fragments of nonwelded to partially welded ash-flow and ash-fall tuff. Fresh surfaces and angularity of some fragments indicate they were derived from larger fragments due to drilling.

Paintbrush Tuff

Tiva Canyon Member

Tuff (columnar), ash-flow, grayish-red and pale reddish-brown, densely welded, devitrified; pumice, medium-gray, devitrified; phenocrysts, 3 percent, sanidine, plagioclase, rare biotite and rare sphene; rare rhyolitic-lithic fragments. Manganese oxide dendrites on fracture surfaces.

Borehole number UE-25 UZN \#10

Paintbrush Tuff

Tiva Canyon Member

Tuff (shardy base), ash-flow, grayish-orange to light-brown, nonwelded to partially welded, vitric, partially argillized; pumice, very light-gray to light-gray, argillized, up to $30 \mathrm{mil}$ limeters, flattened 2:1; phenocrysts, 3 to 5 percent, sanidine and plagioclase; abundant black and amber glass shards. High-angle fracture with manganese oxide coating at 1.22 meters. Increase in black glass shards at 4.27 meters. 
Table 3. Lithologic logs of the neutron-access boreholes at Yucca Mountain--Continued

Stratigraphic and lithologlc description

\section{Thickness of interval \\ (meters)}

Depth $t$ -

bottom of

interva'

(meters)

Borehole number UE-25 UZN \#10-Continued

Paintbrush Tuff

7.62

7.62

Tiva Canyon Member

Tuff (shardy base), ash-flow, grayish-orange to light-brown, nonwelded to partially welded, vitric, partially argillized; pumice, very light-gray to light-gray, argillized, up to $30 \mathrm{mil}-$ limeters, flattened 2:1; phenocrysts, 3 to 5 percent, sanidine and plagioclase; abundant black and amber glass shards. High-angle fracture with manganese oxide coating at 1.22 meters. Increase in black glass shards at 4.27 meters.

Bedded tuff

Tuff, ash-fall, very light-gray, moderately indurated, vitric; pumice, grayish-pink, rounded; phenocrysts, less than 1 percent, sanidine; abundant clear glass shards.

Tuff, ash-fall, white, moderately indurated, vitric, partially argillized; pumice, white, argillized; rare medium-dark-gray to dark-gray rhyolitic-lithic fragments.

Yucca Mountain Member

Tuff, ash-flow, grayish-orange-pink to light-brownish-gray, nonwelded to partially welded, vitric; pumice, pinkish-gray, argillic; phenocrysts, less than 1 percent, sanidine; rare rhyolitic-lithic fragments; common clear glass shards.

Tuff, ash-flow, pale-yellowish-brown to pale-brown, partially welded, partially devitrified; pumice, white, vitric, flattened 4:1; phenocrysts, less than 1 percent, sanidine; common to abundant clear glass shards, quantity increases with depth.

Tuff, ash-flow, grayish-orange-pink, pale-yellowish-brown and pale-brown with increasing depth, nonwelded to partially welded, vitric; pumice, grayish-pink to moderate-orangepink vitric, partially argillized, up to 10 millimeters, flattened $3: 1$; phenocrysts, 3 to 5 percent; rare rhyolitic-lithic fragments; abundant black glass shards.

Tuff, ash-flow, light-brownish-gray, nonwelded, vitric; pumice, white to grayish-orangepink, vitric; phenocrysts, 1 percent, sanidine and plagioclase; sparse rhyolitic-lithic fragments; abundant clear glass shards.

Bedded Tuff

Tuff, ash-fall, white to very pale orange, partially argillized; pumice, white, argillized; abundant phenocrysts, quartz, sanidine and plagioclase; occasional rhyolitic-lithic fragments; sparse clear glass shards. Increase in size and quantity of lithic fragments at 25.30 meters, up to 10 millimeters and 15 percent.

Tuff, ash-fall, weathered, moderate-orange-pink to grayish-orange, argillized; pumice, white to moderate-orange-pink, argillic; phenocrysts, common sanidine and plagioclase; abundant, rounded rhyolitic-lithic fragments. 
Table 3. Lithologic logs of the neutron-access boreholes at Yucca Mountain--Continued

Stratigraphic and lithoiogic description
Borehole number UE-255 UZN \#12
Alluvium and colluvium, consisting of silt-sized to pebble-gravel-sized, subangular to sub-
rounded, light-gray to medium-gray and pale-red to grayish-red, moderately to densely
welded ash-flow tuff fragments. Secondary carbonate coatings and discoloration of
fragments. Some fragments are angular with fresh surfaces indicating they were
chipped from larger pieces.
Paintbrush Tuff
Tiva Canyon Member
Tuff (hackly), ash-flow, pale-reddish-brown and grayish-red, densely welded, devitrified;
pumice, light-gray, devitrified; phenocrysts, 5 percent, sanidine, plagioclase, biotite,
rare hornblende and rare sphene; occasional rhyolitic-lithic fragments. Disseminated
manganese oxide dendrites.

\section{Borehole number UE-25 UZN \#13}

Total depth

Alluvium and colluvium, consisting of silt-sized to boulder-gravel-sized, subangular to subrounded, moderately to densely welded ash-flow tuffs. Rare fragments of nonwelded to partially welded ash-flow and ash-fall tuff. Fresh surfaces and angularity of some fragments indicate they were derived from larger fragments due to drilling.

Timber Mountain Tuff

Rainier Mesa Member

Tuff, ash-flow, pale-red, partially welded, devitrified; pumice, very light gray, light-gray and medium-light-gray, vesicular with vapor phase crystallization; phenocrysts, 15 to 17 percent, sanidine, plagioclase, quartz and bronze biotite; abundant rhyolitic-lithic fragments.

\section{Borehole number UE-25 UZN \#14}

Alluvium and colluvium, consisting of very coarse sand to pebble-gravel-sized, light brown, light-gray to medium-gray, subangular to subrounded, moderately to densely welded tuffs of the Tiva Canyon Member. Some fragments with a grayish-orange, slightly calcareous coating.

Alluvium and colluvium, consisting of silt-sized to pebble-sized gravel, grayish-orangepink to light brown and light gray, poorly sorted, subangular to subrounded, moderately to densely welded ash-flow tuffs of the Tiva Canyon Member. Silt-sized to medium sand-sized portion is grayish-orange-pink to light-brown. The angularity and unweathered surfaces of some of the chips indicate they are broken from larger pieces.

Timber Mountain Tuff

Rainier Mesa Member

Tuff, ash-flow, medium-light-gray and pale-red, partially welded, devitrified; pumice, medium-gray to medium-dark-gray, vesicular with evidence of vapor-phase crystallization; phenocrysts, 10 to 12 percent, feldspar, quartz and biotite. No lithic fragments were seen in the cuttings. 
Table 3. Lithologic logs of the neutron-access boreholes at Yucca Mountain--Continued

\section{Stratigraphic and lithologic description}

Alluvium and colluvium, consisting of silt-sized to gravel-sized, subangular to subrounded, light-gray to medium-gray and pale-red to grayish-red, moderately to densely welded ash-flow tuff fragments. Secondary carbonate coatings and discoloration of fragments. Fresh surfaces on some fragments indicates chipping from larger pieces.

Paintbrush Tuff

Tiva Canyon Member

Tuff (hackly), ash-flow, pale-reddish-brown and grayish-red, densely welded, devitrified; pumice, medium-light-gray and medium-gray, devitrified; phenocrysts, 3 to 5 percent, sanidine, plagioclase and biotite; sparse rhyolitic-lithic fragments. Disseminated manganese oxide dendrites. Siliceous fracture fill material and breccia in cuttings.

\section{Borehole number UE-25 UZN \#19}

Alluvium and colluvium, consisting of silt-sized to gravel-sized, subangular to subrounded, moderately to densely welded tuff fragments. Secondary carbonate coatings on some fragments. Fresh surfaces and angularity of some pieces indicate they were chipped from larger fragments.

Paintbrush Tuff

Tiva Canyon Member

Tuff (columnar), ash-flow, moderate-brown, densely welded, devitrified; pumice, mediumgray and medium-dark-gray, devitrified; phenocrysts, 3 percent, sanidine, plagioclase and biotite; occasional rhyolitic-lithic fragments. Sparse manganese oxide dendrites in matrix.

\section{Borehole number UE-25 UZN \#20}

Alluvium and colluvium, consisting of silt-sized to boulder-gravel-sized, subangular to subrounded, moderately to densely welded ash-flow tuff fragments. Rare fragments of nonwelded to partially welded ash-flow tuff and ash-fall tuff. Common secondary carbonate coatings on some fragments. Fresh surfaces and angularity of some pieces indicate they were derived from larger fragments due to drilling.

\section{Paintbrush Tuff}

Tiva Canyon Member

Tuff (hackly), ash-flow, pale-red to pale-reddish-brown, densely welded, devitrified; pumice, light-gray to medium-light-gray, devitrified; phenocrysts, 3 to 5 percent, sanidine, plagioclase and rare hornblende; sparse, light-gray rhyolitic-lithic fragments. Some calcium carbonate and manganese oxide coatings on fracture faces.

\section{Borehole number UE-25 UZN \#21}

Alluvium and colluvium, consisting of silt-sized to gravel-sized, subangular to subrounded, light-gray to medium-light-gray and grayish-red, moderately to densely welded ashflow tuff.Secondary carbonate coatings and discoloration. Fresh surfaces on some fragments indicate they were chipped from larger pieces.

Thickness of
Interval
(meters)

Depth tc

bottom $c^{*}$ Interval

(meters)

Total depth 
Table 3. Lithologic logs of the neutron-access boreholes at Yucca Mountain--Continued

Stratigraphic and lithologic description
Borehole number UE-25 UZN \#21-Continued
Paintbrush Tuff
Tiva Canyon Member
Tuff (hackly), ash-flow, pale-red to pale-reddish-brown, densely welded, devitrified; pum-
ice, light-gray to medium-light-gray, devitrified; phenocrysts, 3 to 5 percent, sanidine
and plagioclase; sparse, light-gray and very light gray rhyolitic-lithic fragments. Man-
ganese oxide dendrites disseminated in matrix. Secondary carbonate coatings and man-
ganese oxide dendrites on fracture faces.

\section{Borehole number UE-25 UZN \#22}

Alluvium, consisting of silt-sized to gravel-sized, subrounded to subangular, moderately to densely welded, ash-flow tuff fragments. Secondary carbonate coatings and discoloration. Fresh surfaces on some fragments indicate they were chipped from larger pieces.

Paintbrush Tuff

\section{Thickness of Interval \\ (meters)}

Depth to bottom of interval (meters)

Tiva Canyon Member

Tuff (lower lithophysal), ash-flow, grayish-red, densely welded, devitrified; pumice, medium-light-gray, devitrified; phenocrysts, 5 to 7 percent, sanidine, plagioclase; rare rhyolitic-lithic fragments. Manganese oxidedendrites disseminated in matrix. Lithophysal cavities with vapor-phase crystallization.

Tuff (hackly), ash-flow, pale-reddish-brown, densely welded, devitrified; pumice, lightgray to medium-light-gray, devitrified; phenocrysts, 5 to 7 percent, sanidine, plagioclase; rare rhyolitic-lithic fragments. Calcareous fracture fill material. Disseminated manganese oxide dendrites in matrix. Vapor-phase crystallization in lithophysal cavities.

Borehole number UE-25 UZN \#23

Paintbrush Tuff

Tiva Canyon Member

Tuff (lower lithophysal), ash-flow, pale-reddish-brown to grayish-red, densely welded, devitrified; pumice, light-gray, devitrified; phenocrysts, 3 to 5 percent, sanidine and plagioclase. Common lithophysal cavities with vapor-phase crystallization. Disseminated manganese oxide dendrites.

Tuff (hackly), ash-flow, pale-reddish-brown, densely welded, devitrified; pumice, lightgray to medium-light-gray, devitrified; phenocrysts, 5 to 7 percent, sanidine and plagioclase; rare rhyolitic-lithic fragments. Disseminated manganese oxide dendrites in matrix. Vapor-phase crystallization in lithophysal cavities.

Borehole number USW UZ-N24

Alluvium and colluvium, consisting of fine sand-sized to gravel-sized, densely welded Tiva .15 Canyon tuff fragments. 
Table 3. Lithologic logs of the neutron-access boreholes at Yucca Mountain--Continued

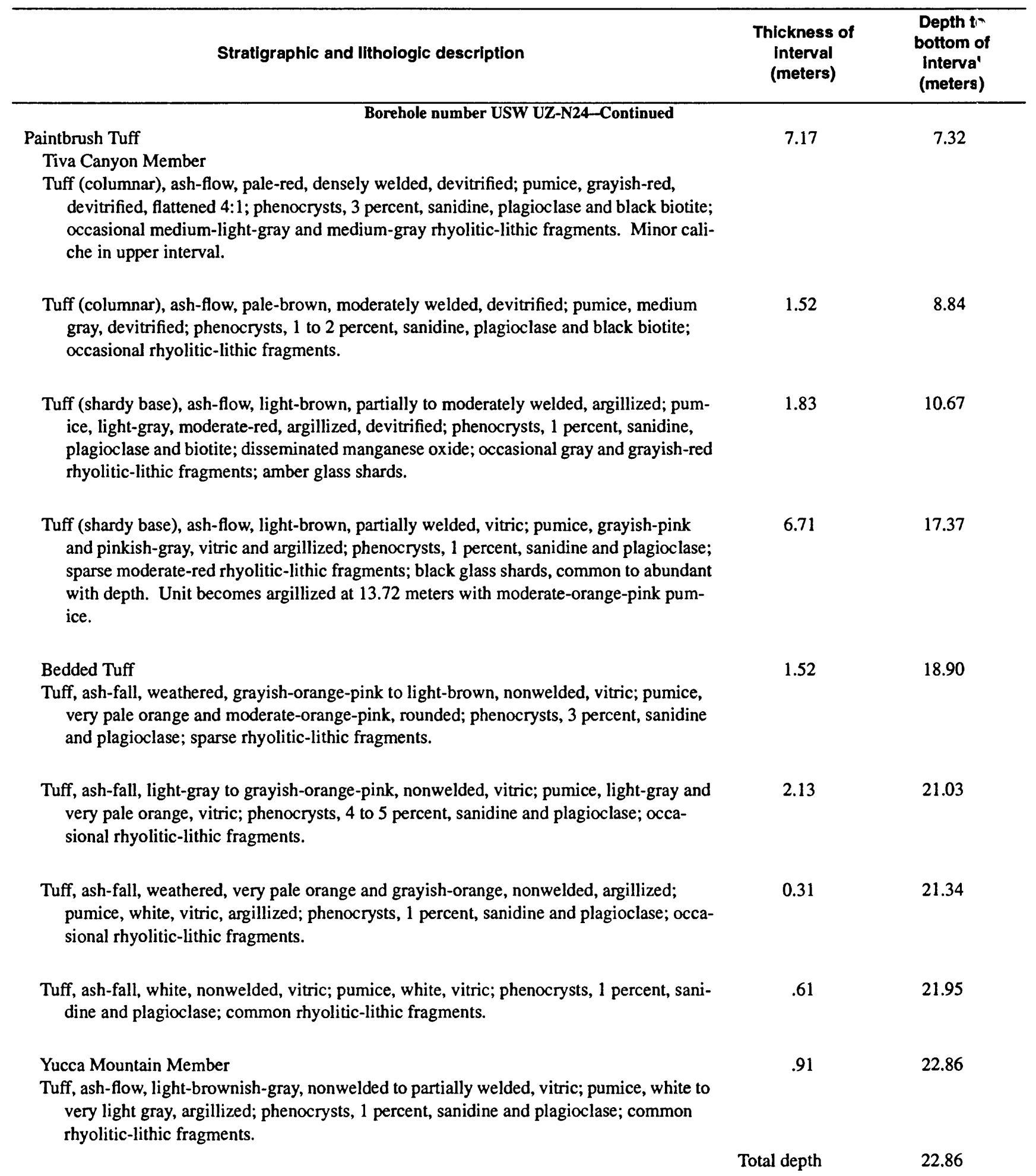


Table 3. Lithologic logs of the neutron-access boreholes at Yucca Mountain--Continued

Stratigraphic and lithologic description
Borehole number USW UZ-N25
Paintbrush Tuff
Tiva Canyon Member
Tuff (hackly), ash-flow, pale-brown to moderate-brown, densely welded, devitrified; pum-
ice, medium-dark-brown, devitrified; phenocrysts, 3 percent, sanidine and plagioclase;
sparse rhyolitic-lithic fragments. Disseminated manganese oxide dendrites.
Tuff (columnar), ash-flow, light-brownish-gray to brownish-gray, densely welded, devitri-
fied; pumice, dark-gray, devitrified; phenocrysts, 2 to 3 percent, sanidine, and plagio-
clase; occasional rhyolitic-lithic fragments. Manganese oxide dendrites on cooling
joint surfaces.

Borehole number USW UZ-N26

\begin{tabular}{cc}
$\begin{array}{c}\text { Thickness of } \\
\text { Interval }\end{array}$ & $\begin{array}{c}\text { Depth to } \\
\text { I ittom of } \\
\text { interval } \\
\text { (meters) }\end{array}$ \\
\hline
\end{tabular}

$8.23 \quad 8.23$

Paintbrush Tuff

Total depth

17.98

Tiva Canyon Member

Tuff (lower lithophysal), ash-flow, pale-reddish-brown and grayish-red, densely welded, devitrified; pumice, very light gray, light-gray, and medium-dark-gray, devitrified; phenocrysts, 2 to 3 percent, sanidine, plagioclase, and biotite, sparse rhyolitic-lithic fragments. Abundant to sparse lithophysal cavities with vapor-phase crystallization and very light gray to light-gray alteration halos. Disseminated manganese oxide dendrites.

\section{Borehole number UE-25 UZN \#28}

Total depth

Alluvium and colluvium, consisting of silt-sized to gravel-sized, subrounded to subangular, moderately to densely welded, ash-flow tuff fragments. Secondary carbonate coatings and discoloration of some fragments. Fresh surfaces and angularity of some fragments indicate they were chipped from larger pieces.

\section{Borehole number UE-25 UZN \#29}

Alluvium and colluvium, consisting of silt-sized to gravel-sized, subrounded to subangular, moderately to densely welded, ash-flow tuff fragments. Secondary carbonate coatings on some fragments. Fresh surface and angularity of some fragments indicate they were derived from larger fragments.

Paintbrush Tuff

Tiva Canyon Member

Tuff (clinkstone), ash-flow, grayish-red, densely welded, devitrified; phenocrysts, 3 to 5 percent, sanidine and plagioclase; sparse rhyolitic-lithic fragments. Disseminated manganese oxide dendrites. Occasional calcareous coatings on fracture surfaces.

Tuff (lower lithophysal), ash-flow, pale-red to grayish-red, densely welded, devitrified; pumice, grayish-pink, very light gray, and light-gray, devitrified; phenocrysts, 3 percent, sanidine and plagioclase; occasional rhyolitic-lithic fragments. Evidence of lithophysal cavities with vapor-phase crystallization. Disseminated manganese oxide dendrites. 
Table 3. Lithologic logs of the neutron-access boreholes at Yucca Mountain--Continued

Stratlgraphic and Ilthologic descriptlon
Borehole number UE-25 UZN \#30
Alluvium and colluvium, consisting of silt-sized to gravel-sized, subrounded to subangular,
moderately to densely welded, ash-flow tuff fragments. Secondary carbonate coatings
on some fragments. Fresh surfaces and angularity of some fragments indicate they
were derived from larger fragments.
Paintbrush Tuff
Tiva Canyon Member
Tuff (lower lithophysal), ash-flow, pale-red to grayish-red, densely welded, devitrified;
pumice, very light gray, devitrified; phenocrysts, 3 to 5 percent, sanidine and plagio-
clase. Occasional rhyolitic-lithic fragments. Disseminated manganese oxide dendrites.
Evidence of lithophysal cavities with vapor-phase crystallization.

\section{Borehole number USW UZ-N40}

Alluvium and colluvium, consisting of silt-sized to gravel-sized, subrounded to subangular, moderately to densely welded, ash-flow tuff fragments. Secondary carbonate coatings on some fragments. Fresh surfaces and angularity of some fragments indicate they were derived from larger fragments.

Paintbrush Tuff

Depth to bottom of Intervi-1

(metern)

\section{Tiva Canyon Member}

Tuff (lower lithophysal), ash-flow, grayish-red, densely welded, devitrified; pumice, light gray, devitrified; phenocrysts, 2 to 3 percent, sanidine, plagioclase and rare biotite. Abundant lithophysal cavities with vapor-phase crystallization and very light gray to light-gray alteration halos.

Tuff (hackly), ash-flow, grayish-red and moderate-reddish-brown, densely welded, devitrified; pumice, light-gray, devitrified; phenocrysts, 3 to 5 percent, sanidine, plagioclase, rare biotite and rare hornblende; rare rhyolitic-lithic fragments.

\section{Borehole number USW UZ-N41}

Alluvium and colluvium, consisting of silt-sized to gravel-sized, subrounded to subangular, moderately to densely welded, ash-flow tuff fragments. Secondary carbonate coatings on some fragments. Fresh surface and angularity of some fragments indicate they were derived from larger fragments.

Paintbrush Tuff

Tiva Canyon Member

Tuff (lower lithophysal), ash-flow, grayish-red, pale-reddish-brown, and moderate-reddishbrown, densely welded, devitrified; pumice, light-gray and medium-gray, devitrified; pheno-crysts, 2 to 3 percent, sanidine, plagioclase, sparse biotite, and rare sphene; sparse rhyolitic lithic fragments. Occasional lithophysal cavities with vapor-phase crystallization.

Total depth 
Table 3. Lithologic logs of the neutron-access boreholes at Yucca Mountain--Continued

\begin{tabular}{l} 
Stratigraphic and lithologic description \\
\hline Borehole number USW UZ-N42 \\
Paintbrush Tuff \\
Tiva Canyon Member \\
Tuff (lower lithophysal), ash-flow, grayish-red, densely welded, devitrified; pumice, very \\
light gray and light-gray, devitrified; phenocrysts, 3 percent, sanidine, plagioclase, rare \\
biotite and rare sphene; occasional rhyolitic-lithic fragments. Abundant lithophysal \\
cavities with vapor-phase crystallization and very light gray alteration halos.
\end{tabular}

Borehole number USW UZ-N43

Total depth

Alluvium and colluvium, consisting of silt-sized to gravel-sized, subrounded to subangular, moderately to densely welded, ash-flow tuff fragments. Secondary carbonate coatings on some fragments. Fresh surface and angularity of some fragments indicate they were derived from larger fragments.

Paintbrush Tuff

Tiva Canyon Member

Tuff (hackle), ash-flow, grayish-red, densely welded, devitrified; pumice, light-gray and medium-gray, devitrified; phenocrysts, 3 to 5 percent, sanidine and plagioclase. Occasional rhyolitic-lithic fragments. Disseminated manganese oxide dendrites.

Tuff (columnar), ash-flow, grayish-red and moderate-reddish-brown, mottled, densely welded, devitrified; pumice, grayish-red, devitrified; phenocrysts, 3 to 5 percent, sanidine and plagioclase. Occasional rhyolitic lithic fragments.

\section{Borehole number USW UZ-N44}

Total depth

Paintbrush Tuff

Tiva Canyon Member

Tuff (lower lithophysal), ash-flow, grayish-red, densely welded, devitrified; pumice, very light gray and light-gray, devitrified; phenocrysts, 3 percent, sanidine, plagioclase and rare biotite; occasional rhyolitic-lithic fragments. Abundant lithophysal cavities with vapor-phase crystallization and very light gray alteration halos.

\section{Borehole number USW UZ-N45}

Alluvium and colluvium, consisting of silt-sized to gravel-sized, subrounded to subangular, moderately to densely welded, ash-flow tuff fragments. Secondary carbonate coatings on some fragments. Fresh surfaces and angularity of some fragments indicate they were derived from larger fragments.

Paintbrush Tuff

Tiva Canyon Member

Tuff (hackle), ash-flow, grayish-red to moderate-reddish-brown, densely welded, devitrified; pumice, light-gray and medium-gray, devitrified; phenocrysts, 3 percent, sanidine, plagioclase, and rare biotite; occasional rhyolitic-lithic fragments. 


\begin{tabular}{llc}
\hline Stratigraphic and lithologic description & $\begin{array}{c}\text { Thickness of } \\
\text { Interval } \\
\text { (meters) }\end{array}$ & $\begin{array}{c}\text { Depth in } \\
\text { bottom of } \\
\text { interve' } \\
\text { (meters) }\end{array}$ \\
\hline
\end{tabular}

Paintbrush Tuff

2.13

Yucca Mountain Member

Tuff, ash-flow, light-gray to light-brownish-gray, nonwelded to partially welded, vitric; pumice, white, vitric; phenocrysts, less than 1 percent, sanidine, plagioclase; rare rhyolitic-lithic fragments; abundant clear glass shares.

Tuff, ash-flow, light-gray, partially welded, partially devitrified; pumice, very light gray, devitrified and medium-light-gray, partially devitrified, vuggy with vapor-phase crystallization, good alignment of small pumice, flattened 3:1; phenocrysts, less than 1 percent, sanidine, and plagioclase; rare rhyolitic-lithic fragments.

Tuff, ash-flow, light-brownish-gray, partially to moderately welded, devitrified; pumice, white and medium-light-gray, devitrified; phenocrysts, 1 percent, sanidine and plagioclase (very small), black biotite; sparse disseminated manganese oxide; rare rhyoliticlithic fragments; rare clear glass shares; some vapor-phase crystallization at top of unit.

Tuff, ash-flow, pale-brown, moderately welded, devitrified; pumice, medium-light-gray, devitrified (vapor phase?), flattened 4:1; phenocrysts, 1 percent, sanidine and plagioclase; disseminated manganese oxide; rare rhyolitic-lithic fragments.

Tuff, ash-flow, pale-yellowish-brown grading to light-brown, partially welded, devitrified; disseminated manganese oxide common; rare rhyolitic-lithic fragments.

Tuff, ash-flow, pale-brown to moderate-brown, nonwelded, vitric; pumice, grayish-orangepink, argillized; abundant black glass shards.

Tuff, ash-flow, pale-yellowish-brown to light-brown, nonwelded, vitric; pumice, grayishorange-pink to moderate-orange-pink, argillized; disseminated manganese oxide; abundant clear glass shards, sparse black glass shards.

Bedded tuff

Tuff, ash-fall, white, partially argillic; pumice, white argillized; phenocrysts, abundant quartz, sanidine and plagioclase; common rhyolitic-lithic fragments.

\section{Borehole number USW UZ-N47}

Alluvium and colluvium, consisting of silt-sized to gravel-sized, poorly sorted, subangular to subrounded, light-gray, medium-light-gray and pale-yellowish-brown, moderately to densely welded tuffs.

Paintbrush Tuff

Yucca Mountain Member

Tuff, ash-flow, light-brownish-gray, moderately welded, devitrified; pumice, medium-lightgray to medium-gray, devitrified, vapor-phase crystallization; phenocrysts, 1 percent, sanidine and plagioclase; disseminated manganese oxide; rare, small rhyolitic-lithic fragments. Gradational color change with underlying unit. 
Table 3. Lithologic logs of the neutron-access boreholes at Yucca Mountain--Continued

Stratigraphic and lithologic description

$\begin{array}{cc}\begin{array}{c}\text { Thickness of } \\ \text { interval }\end{array} & \begin{array}{c}\text { Depth to } \\ \text { bottor of } \\ \text { (meters) }\end{array} \\ \begin{array}{c}\text { interval } \\ \text { (meters) }\end{array}\end{array}$

Borehole number USW UZ-N51

Alluvium and colluvium, consisting of silt-sized to gravel-sized, subrounded to angular fragments of partially to densely welded Tiva Canyon ash-flow tuffs. Secondary carbonate coatings and discoloration of some fragments. Fresh surfaces on some fragments indicate they were broken from larger pieces.

Paintbrush Tuff

Tiva Canyon Member

Tuff (hackly), ash-flow, grayish-red and moderate-reddish-brown, densely welded, devitrified; pumice, medium-light-gray and medium-gray, devitrified; phenocrysts, 3 percent, sanidine, plagioclase, hornblende and rare sphene; occasional light-gray rhyolitic-lithic fragments. Evidence of caliche filled fractures.

Borehole number USW UZ-N52

Total depth

Alluvium and colluvium, consisting of silt-sized to gravel-sized, subrounded to angular fragments of partially to densely welded Tiva Canyon ash-flow tuffs. Secondary carbonate coatings on some fragments.

Paintbrush Tuff

Tiva Canyon Member

Tuff (hackly), ash-flow, grayish-red and moderate-reddish-brown, densely welded, devitrified; pumice, medium-light-gray, medium-gray and moderate-reddish-orange, devitrified; phenocrysts, 3 percent, sanidine, plagioclase and hornblende. Evidence of sparse lithophysal cavities with vapor-phase crystallization. Secondary carbonate to 5.61 meters.

\section{Borehole number UE-25 UZN \#56}

Total depth

Alluvium and colluvium, consisting of silt-sized to gravel-sized, subrounded to subangular, moderately to densely welded, ash-flow tuff fragments. Secondary carbonate coatings and discoloration present. Fresh surfaces on some fragments indicate they were from larger pieces.

\section{Paintbrush Tuff}

Tiva Canyon Member

Tuff (columnar), ash-flow, pale-brown, densely welded, devitrified; pumice, brownish-gray and dark-gray, devitrified; phenocrysts, 1 to 2 percent, sanidine, plagioclase, and rare biotite; occasional rhyolitic-lithic fragments. Brecciated material in cuttings and evidence of mineralization on fracture surfaces.

\section{Borehole number UE-25 UZN \#60}

Alluvium and colluvium, consisting of silt-sized to boulder-sized, subrounded to subangu-

tially welded ash-flow and ash-fall tuff. Secondary carbonate coatings on some fragments. Fresh surfaces and angularity of some fragments indicate they were derived from larger fragments during drilling. 
Table 3. Lithologic logs of the neutron-access boreholes at Yucca Mountain--Continued

Stratigraphic and lithologic description
Borehole number UE-25 UZN \#60-Continued
Paintbrush Tuff
Tiva Canyon Member
Tuff (clinkstone), ash-flow, pale-red, densely welded, devitrified; pumice, light-gray, devit-
rified; phenocrysts, 2 to 3 percent, sanidine and plagioclase. Disseminated manganese
oxide dendrites in matrix.

Borehole number USW UZ-N65

Paintbrush Tuff

Thickness of

interval

(meters)
C spth to

binttom of

interval

(meters)

Tiva Canyon Member

Tuff (upper cliff), ash-flow, light-gray, moderately welded, devitrified; pumice, very light gray, devitrified; phenocrysts, 10 to 12 percent, sanidine, plagioclase and bronze biotite. Common vapor-phase crystallization and lithophysal cavities.

Tuff (upper lithophysal), ash-flow, medium-gray to light-brownish-gray, moderately welded, devitrified; pumice, very light gray, devitrified; phenocrysts, 5 percent, sanidine, plagioclase and biotite. Disseminated manganese oxide dendrites. Very light gray alteration halos surrounding lithophysal cavities. Vapor-phase crystallization.

\section{Borehole number USW UZ-N66}

Total depth

6.10

9.14

Paintbrush Tuff

Tiva Canyon Member

Tuff (clinkstone), ash-flow, light-brownish-gray to pale-red, densely welded, devitrified; pumice, very light gray, devitrified; phenocrysts, 3 to 5 percent, sanidine, plagioclase and biotite; rare light-gray rhyolitic-lithic fragments. Evidence of weathering in fractures to 7.32 meters.

\section{Borehole number USW UZ-N67}

Alluvium and colluvium, consisting of silt-sized to gravel-sized, subrounded to subangular, moderately to densely welded, ash-flow tuff fragments. Secondary carbonate coatings and discolorations of some fragments. Fresh surfaces and angularity of some fragments indicate they were chipped from larger pieces. Rare to sparse nonwelded to partiallywelded fragments of ash-flow and ash-fall tuff.

Tiva Canyon Member

Tuff (caprock), ash-flow, very light gray and grayish-orange-pink, partially welded, devitrified; pumice, light-gray, and medium-light-gray, devitrified, vesicular with vapor-phase crystallization; phenocrysts, 15 to 20 percent, alkali feldspar, plagioclase, and bronze biotite.

\section{Borehole number USW UZ-N68}

Alluvium and colluvium, consisting of silt-sized to gravel-sized, subrounded to subangular, 
Table 3. Lithologic logs of the neutron-access boreholes at Yucca Mountain--Continued

Stratigraphic and lithologic description
Borehole number USW UZ-N68-Continued
Rainier Mesa Member
Tuff, ash-flow, white, nonwelded, vitric; pumice, white, vitric, good tubular structure; phe-
nocrysts, 10 percent, quartz, biotite, and sphene; occasional small (less than 1 millime-
ter) rhyolitic-lithic fragments. Common bipyramidal aquartz phenocrysts.
Blluvium and colluvium, consisting of silt-sized to boulder-sized, subrounded to subangu-
lar, moderately to densely welded ash-flow tuff fragments. Rare to common nonwelded
to partially welded ash-flow and ash-fall tuff fragments. Fresh surfaces and angularity
of some fragments indicate they were derived from larger fragments due to drilling.
Rainier Mesa Member
Tuff, ash-flow, medium-light-gray, partially welded, devitrified; pumice, light-gray and
medium-light-gray, devitrified, vesicular with vapor-phase crystallization; phenocrysts,
15 to 20 percent, alkali feldspar, plagioclase, quartz, bronze biotite and rare sphene.

Borehole number USW UZ-N70

Paintbrush Tuff
Thickness of interval
(meters)

1.52

16.76

Total depth

Total depth

10.67

10.67

Tiva Canyon Member

Tuff (lower lithophysal), ash-flow, pale-reddish-brown to grayish-red, densely welded, devitrified; pumice, light-gray, devitrified; phenocrysts, 2 to 3 percent, sanidine, plagioclase, and sparse biotite. Occasional disseminated manganese oxide dendrites. Lithophysal cavities with light-gray alteration halos and vapor-phase crystallization.

\section{Borehole number USW UZ-N71}

Paintbrush Tuff

Tiva Canyon Member

Tuff (caprock), ash-flow, light-gray to light-brownish-gray, moderately welded, devitrified; pumice, white and medium-gray, devitrified, vesicular with vapor-phase crystallization; phenocrysts, 15 to 20 percent, sanidine, plagioclase, and biotite; occasional rhyoliticlithic fragments.

Tuff (upper cliff), ash-flow, light-gray to light-brownish-gray, moderately welded, devitrified; pumice, white and very light gray, devitrified; phenocrysts, 7 to 10 percent, sanidine, plagioclase, biotite, and rare sphene; sparse rhyolitic-lithic fragments.

\section{Borehole number USW UZ-N72}

Paintbrush Tuff

Tiva Canyon Member

Tuff (upper cliff), ash-flow, light-gray to medium-light-gray and light-brownish-gray, moderately welded, devitrified; pumice, very light gray and grayish brown, devitrified, vapor-phase crystallization; phenocrysts, 10 to 12 percent, sanidine, plagioclase, bronze biotite, sparse sphene and rare hornblende.

Tuff (upper cliff), ash-flow, light-gray to light-brownish-gray, moderately welded, devitrified; pumice, very light gray and light-brown, devitrified; phenocrysts, 10 percent, sanidine, plagioclase and biotite. Rare rhyolitic-lithic fragments.
Depth to

bottom of

intervil

(meter:) 
Table 3. Lithologic logs of the neutron-access boreholes at Yucca Mountain--Continued

Stratigraphic and lithologic description
Borehole number USW UZ-N72-Continued
Tuff (upper cliff), ash-flow, light-gray to light-brownish-gray, moderately welded, devitri-
fied; pumice, very light gray, devitrified; phenocrysts, 5 to 7 percent, sanidine, plagio-
clase and biotite. Lithophysal cavities with light-gray alteration halos and vapor-phase
crystallization.

Borehole number USW UZ-N73

Paintbrush Tuff

Thlckness of
interval
(meters)

1.22

Total depth

9.14

Tiva Canyon Member

Tuff (upper lithophysal), ash-flow, light-gray to light-brownish-gray, moderately welded, devitrified; pumice, light-gray and medium-gray, devitrified; phenocrysts, 7 percent, sanidine, plagioclase and biotite. Disseminated manganese oxide dendrites. Lithophysal cavities with vapor-phase crystallization.

Borehole number USW UZ-N74

Total depth

Paintbrush Tuff 5.79

Tiva Canyon Member

Tuff (caprock), ash-flow, very light gray and light-brownish-gray, moderately welded, devitrified; pumice, white, medium-light-gray, and medium-dark-gray, devitrified, vapor-phase crystallization; phenocrysts, 12 to 15 percent, sanidine, plagioclase, biotite, and sphene.

Tuff (upper cliff), ash-flow, light-gray to light-brownish-gray, moderately welded, devitrified; pumice, very light gray and light-brown, devitrified; phenocrysts, 10 percent, sanidine, plagioclase, and biotite; rare rhyolitic-lithic fragments.

\section{Borehole number USW UZ-N75}

Alluvium and colluvium, consisting of silt-sized to boulder-sized, subrounded to subangular, moderately welded ash-flow tuff fragments (Tiva Canyon caprock). Some fragments have discolored surfaces, most have fresh angular surfaces.

Paintbrush Tuff

Tiva Canyon Member

Tuff (upper cliff), ash-flow, light-gray to light-brownish-gray, moderately welded, devitrified; pumice, very light gray and light-brown, devitrified; phenocrysts, 10 percent, sanidine, plagioclase, and biotite; rare rhyolitic-lithic fragments.

Tuff (upper lithophysal), ash-flow, light-gray to light-brownish-gray, moderately welded, devitrified; pumice, very light gray, devitrified; phenocrysts, 5 to 7 percent, sanidine, plagioclase, and biotite. Sparse lithophysal cavities with vapor-phase crystallization and light-gray alteration halos.
Dinth to

bottom of irterval

(meters) 
Table 3. Lithologic logs of the neutron-access boreholes at Yucca Mountain--Continued

Stratlgraphic and lithologlc description
Borehole number USW UZ-N76
Paintbrush Tuff
Tiva Canyon Member
Tuff (upper cliff), ash-flow, light-gray to medium-light-gray, moderately welded, devitri-
fied; pumice, white, very light gray and light-gray, partially devitrified, possible clay
alteration; phenocrysts, 15 percent, sanidine, plagioclase, black and bronze biotite.
Vapor phase crystallization in lithophysal cavities and in vesicular pumice. Secondary
carbonate coatings on fragments indicates extensive fracturing to total depth. Abundant
smectitic clay in cuttings. Manganese oxide and siliceous coatings on some fracture sur-
faces.

Paintbrush Tuff

Tiva Canon Member--Continued

Tuff (upper lithophysal), ash-flow, light-gray, light-brownish-gray and pale-red, moderately welded, devitrified; pumice, very light gray, devitrified; phenocrysts, 7 percent, sanidine, plagioclase and sparse biotite. Disseminated vapor-phase crystallization. Abundant secondary manganese oxide dendrites. Sparse lithophysal cavities with carbonate and clay indicate fracturing. Some calcite at 10.97 to 11.58 meters.

\section{Borehole number USW UZ-N77}

Total depth

Alluvium and colluvium, consisting of silt-sized to gravel-sized fragments of nonwelded to densely welded Paintbrush Tuff. The angularity and fresh surfaces on some of the fragments indicate that they were derived from larger blocks. The cuttings from 10.36- to 10.67-meter intervals are composed of 75 percent of Tiva Canyon Member (upper cliff unit).

\section{Paintbrush Tuff}

Tiva Canyon Member

Tuff (clinkstone), ash-flow, pale-red and grayish-pink, densely welded, devitrified; pumice, very light gray to light-gray, devitrified; phenocrysts, 3 to 5 percent, sanidine, rare biotite and a trace of hornblende; rare rhyolitic-lithic fragments; occasional calcite with included brecciated fragments.

Borehole number USW UZ-N78

$11.58 \quad 11.58$

Paintbrush Tuff

Tiva Canyon Member

Tuff (caprock), ash-flow, light-gray to moderate-light-gray, moderately welded, devitrified; pumice, white to very light gray, moderate-brown and medium-gray pumice is vesicular, white pumice is devitrified; phenocrysts, 12 to 15 percent, sanidine, plagioclase, bronze biotite and rare sphene; abundant vapor-phase crystallization.

Tuff (upper cliff), ash-flow, light-gray, pale-red, light-brownish-gray, moderately welded, devitrified; pumice, white and medium-light-gray, partially devitrified; phenocrysts, 10 to 12 percent, sanidine, plagioclase, bronze biotite and rare sphene; rare rhyolitic-lithic fragments; common vapor-phase crystallization.

Tuff (upper lithophysal), ash-flow, light-gray and pale-red, moderately welded, devitrified; pumice, white, partially devitrified; phenocrysts, 5 percent, sanidine, plagioclase, bronze and black biotite and rare sphene; occasional disseminated manganese oxide; lithophysal cavities with vapor-phase crystallization. 
Table 3. Lithologic logs of the neutron-access boreholes at Yucca Mountain--Continued

Stratigraphic and lithologic description
Borehole number USW UZ-N79
Tiva Canyon Member
Tuff (upper lithophysal), ash-flow, light-gray to light-brownish-gray, moderately welded,
devitrified; pumice, very light gray, devitrified; phenocrysts, 3 to 5 percent, sanidine,
plagioclase, biotite; rare rhyolitic-lithic fragments; lithophysal cavities with vapor-
phase crystallization; manganese oxide in matrix; calcium carbonate filled fractures.
Tuff (clinkstone), ash-flow, light-brownish-gray to pale-red, densely welded, devitrified;
pumice, light-gray, devitrified; phenocrysts, 3 percent, sanidine, plagioclase and biotite;
no lithic fragments seen; disseminated manganese oxide dendrites; calcium carbonate
filled fractures.

Borehole number USW UZ-N80

Paintbrush Tuff

Topopah Spring Member

Tuff (brick), ash-flow, moderate-reddish-brown, moderately to densely welded, devitrified; pumice, grayish-red and moderate-light-gray, devitrified, flattened 3:1 to 6:1; phenocrysts, 3 percent, plagioclase and biotite; rare light-gray rhyolitic-lithic fragments; manganese oxide staining on apparent fracture surfaces.

\section{Borehole number USW UZ-N81}

Alluvium and colluvium, consisting of silt-sized to gravel-sized, very light gray, light-gray, pale-red and light-brown, subrounded to subangular, moderately to densely welded ashflow tuffs. Secondary carbonate coatings on some fragments.

Paintbrush Tuff

Thickness of
Interval
(meters)

Depth to ittom of Interval

(meters)

3.05

Total depth

\section{Tiva Canyon Member}

Tuff (clinkstone), ash-flow, pale-red and light-gray, mottled, densely welded, devitrified; pumice, very light gray, devitrified; phenocrysts, 5 percent, sanidine, rare biotite; rare shyolitic-lithic fragments; disseminated manganese oxide in matrix. Brecciated fragments and evidence of fracture coatings. Rare lithophysal cavities at 20.73 to 21.34 meters, with vapor-phase crystallization.

\section{Borehole number USW UZ-N82}

Alluvium and colluvium, consisting of silt-sized to gravel-sized fragments of partially to densely welded Paintbrush Tuff. Fragments are subrounded to angular with some secondary carbonate coatings. Fresh surface on some fragments indicate they were derived from larger fragments.

Paintbrush Tuff

Tiva Canyon Member

Tuff (upper lithophysal), ash-flow, light-brownish-gray to brownish-gray and pale-red, densely welded, devitrified; pumice, very light gray, devitrified; phenocrysts, 5 percent, sanidine, rare biotite; disseminated manganese oxide in matrix. Very light gray alteration halos around lithophysal cavities.

Tuff (clinkstone), ash-flow, light-brownish-gray, densely welded, devitrified; pumice, lightgray, devitrified; phenocrysts, 3 to 5 percent, sanidine, rare biotite and hornblende; disseminated manganese oxide dendrites in matrix. 
Table 3. Lithologic logs of the neutron-access boreholes at Yucca Mountain--Continued

Stratigraphic and lithologic description
Borehole number USW UZ-N83
Paintbrush Tuff
Tiva Canyon Member
Tuff (clinkstone), ash-flow, pale-red, densely welded, devitrified; pumice, very light gray,
flattened 4:1; phenocrysts, 3 percent, sanidine, plagioclase and a trace of sphene; man-
ganese oxide dendrites in matrix; rare light-gray rhyolitic-lithic fragments. Secondary
carbonate coatings on fragments to 4.89 meters.

\section{Borehole number USW UZ-N84}

Alluvium and colluvium, consisting of silt-sized to boulder-sized fragments of nonwelded

to densely welded rhyolitic tuff. Secondary carbonate down to 3.66 meters.

Tuff (caprock), ash-flow, pale-reddish-brown to moderate-reddish-brown, partially welded, vitric; pumice, moderate-reddish-brown, dark-reddish-brown and medium-gray, vitric, vesicular, some vapor-phase crystallization; phenocrysts, 10 to 12 percent, sanidine, plagioclase biotite and rare sphene; scarce, less than 1 millimeters, rhyolitic-lithic fragments.

Tuff (caprock), ash-flow, pale-red, moderately welded, devitrified; pumice, very light gray, medium-light-gray and moderate-brown, partially vitric; vapor-phase crystallization, vesicular; phenocrysts, 15 percent, sanidine, plagioclase, biotite and rare sphene; rare, less than 2 millimeters, rhyolitic-lithic fragments.

Normal fault at 9.75 meters.

Tuff (upper lithophysal), ash-flow, grayish-red, densely welded, devitrified; pumice, lightgray, devitrified; phenocrysts, 5 percent, sanidine, plagioclase, biotite and rare hornblende; a trace (less than 1 percent), rhyolitic-lithic fragments; manganese oxide dendrites on fracture surfaces.

Reverse fault at 11.58 meters.

Tuff (upper cliff), ash-flow, very light gray, moderately welded, devitrified; pumice, white and light-gray, partially devitrified, light-gray pumice is vesicular; phenocrysts, 12 to 15 percent, sanidine, plagioclase, bronze biotite and rare sphene; rare rhyolitic-lithic fragments; vapor-phase crystallization.

Tuff (upper lithophysal), ash-flow, grayish-red, densely welded, devitrified; pumice, lightgray, devitrified; phenocrysts, 5 percent, sanidine, plagioclase and biotite; rare rhyoliticlithic fragments. Lithophysal cavities with vapor-phase crystallization. Disseminated manganese oxide dendrites on fracture surfaces.

Reverse fault at 12.80 meters.

Tuff (upper cliff), ash-flow, very light gray, moderately welded, devitrified; pumice, white and light-gray, partially devitrified, light-gray pumice is vesicular; phenocrysts, 12 to 15 percent, sanidine, plagioclase, bronze biotite and rare sphene; rare rhyolitic-lithic fragments; vapor-phase crystallization. 
Table 3. Lithologic logs of the neutron-access boreholes at Yucca Mountain--Continued

Stratlgraphic and Ilthologic descrlptlon
Borehole number USW UZ-N84-Continued
Paintbrush Tuff
Tiva Canyon Member Tuff (upper lithophysal), ash-flow, grayish-red, densely welded,
devitrified; pumice, light-gray, devitrified; phenocrysts, 5 percent, sanidine, plagioclase
and biotite; rare rhyolitic-lithic fragments. Lithophysal cavities with vapor-phase crys-
tallization. Disseminated manganese oxide dendrites and dendrites on fracture surfaces.
Note: Intervals from 9.75 to 13.72 meters may be composed of blocks of tuff which have be
plane.
Alluvium and colluvium, consisting of silt-sized to gravel-sized, rounded to subangular,
moderately to densely welded, ash-flow tuff, rhyolitic-lava, and basaltic-lava fragments.
Secondary carbonate coatings and discoloration of some fragments. Fresh surfaces on
some fragments indicate they were derived from larger pieces.

Borehole number USW UZ-N86

Total depth

\begin{tabular}{cc}
$\begin{array}{c}\text { Thlckness of } \\
\text { Interval }\end{array}$ & $\begin{array}{c}\text { Depth to } \\
\text { bottom of } \\
\text { Interval } \\
\text { (meters) }\end{array}$ \\
\hline
\end{tabular}

0.30

Paintbrush Tuff

Total depth

Tiva Canyon Member

Tuff (clinkstone), ash-flow, grayish-red, densely welded, devitrified; pumice, light-gray to medium-light-gray, devitrified, flattened $4: 1$; phenocrysts, 1 to 2 percent, sanidine and plagioclase; manganese oxide dendrites in matrix; rare medium-light-gray rhyoliticlithic fragments; fracture fill material at 3.66 meters. Abundant secondary carbonate coating fragments from 0 to 1.83 meters.

\section{Borehole number USW UZ-N87}

Total depth

Alluvium and colluvium, consisting of silt-sized to boulder-sized, partially to densely welded rhyolitic-lithic fragments. Secondary carbonate and siliceous coatings on some fragments.

\section{Paintbrush Tuff}

Tiva Canyon Member

Tuff (caprock), ash-flow, pale-red to pale-reddish-brown, partially welded, devitrified, vesicular; pumice, moderate-reddish-brown, dark-reddish-brown and light-gray, devitrified, vesicular; phenocrysts, 7 to 10 percent, saniphase crystallization.

Tuff (upper cliff), ash-flow, grayish-red, moderately welded, devitrified; pumice moderatereddish-brown and light-gray, devitrified, vesicular; phenocrysts, 12 to 15 percent, sanidine, plagioclase and bronze biotite; vapor-phase crystallization.

Tuff (upper cliff), ash-flow, pale-red, moderately welded, devitrified; pumice, moderatereddish-brown and light-gray, devitrified, vapor-phase crystallization, vesicular; phenocrysts, 12 to 15 percent, sanidine, plagioclase and bronze biotite; no lithic fragments identified. 
Table 3. Lithologic logs of the neutron-access boreholes at Yucca Mountain--Continued

Stratigraphic and lithologlc description
Borehole number USW UZ-N88
Alluvium and colluvium, consisting of silt-sized to boulder-sized, partially to densely
welded rhyolitic-lithic fragments. Secondary carbonate and siliceous coatings on some
fragments.
Paintbrush Tuff
Tiva Canyon Member
Tuff (upper lithophysal), ash-flow, grayish-red to grayish-brown, densely welded, devitri-
fied; pumice, dusky-brown, devitrified, flattened 5:1; phenocrysts, 3 percent, sanidine,
plagioclase, and a trace of biotite; common rhyolitic-lithic fragments, very light gray
and dark-gray. Secondary carbonate coatings on fragments.
Tuff (clinkstone), ash-flow, grayish-red, densely welded, devitrified; pumice, light-gray and
dark-reddish-brown, devitrified, flattened 6:1; phenocrysts, 2 percent, sanidine and pla-
gioclase, traces of biotite; common rhyolitic-lithic fragments.
Paintbrush Tuff
Tiva Canyon Member
Tuff (clinkstone), ash-flow, pale-red, densely welded, devitrified; pumice, rare, light-gray,
devitrified; phenocrysts, 3 to 5 percent, sanidine and plagioclase; manganese oxide den-
drites in matrix; no lithic fragments seen in cuttings.
to densely welded rhyolitic-lithic fragments. Secondary carbonate coating on frag-
ments.
Bluvium and colluvium, consisting of silt-sized to boulder-sized fragments of moderately
(n)

\section{Borehole number USW UZ-N90}

Alluvium and colluvium, consisting of silt-sized to boulder-sized, nonwelded to densely welded rhyolitic ash-flow tuff fragments.

Tuff (upper lithophysal), ash-flow, pale-red, moderately to densely welded, devitrified; pumice, very light gray, devitrified, flattened $4: 1$; phenocrysts, 1 to 2 percent, sanidine and plagioclase; rare rhyolitic-lithic fragments; lithophysal cavities with vapor-phase crystallization.

\section{Borehole number UE-29 UZN \#91}

Alluvium and colluvium, consisting of silt-sized to gravel-sized, subrounded to subangular, welded ash-flow tuff, rhyolitic-lava fragments, and basaltic-lava fragments. Secondary carbonate coatings and discoloration of some fragments. Fresh surfaces on some fragments indicate they were chipped from larger pieces.

Tuff, undifferentiated

Tuff, ash-flow, light-brown to moderate-brown, moderately welded, devitrified; pumice, white argillized; phenocrysts, less than 1 percent, biotite. 
Table 3. Lithologic logs of the neutron-access boreholes at Yucca Mountain--Continued

Stratigraphic and ilthoiogic description

Thickness of
intervai
(meters)

Tuff, ash-flow, moderate-brown, moderately welded, partially devitrified; pumice, very pale orange, white silicified, and black vitric, concentric banded; phenocrysts, 1 to 2 percent, biotite, and feldspar; sparse lithic fragments. Matrix became vitric at 23.17 meters.

Tuff, ash-flow (?), medium-dark-gray, vitric; phenocrysts, 1 percent, biotite and feldspar.

Tuff, ash-flow, dark-yellowish-brown to grayish-brown, densely welded, partially devitrified; pumice, moderate-orange-pink and very pale orange, devitrified; 1 to 2 percent, feldspar and biotite, occasional rhyolitic-lithic fragments. Black flamme in matrix.

Tuff, ash-flow, pale-red to grayish-red, densely welded, devitrified; pumice, grayish-yellow and light-greenish-gray, devitrified, zeolitized; phenocrysts, 5 percent, biotite, sanidine, plagioclase, and quartz; common rhyolitic-lithic fragments.

Tuff, ash-flow, very pale orange to moderate-orange-pink, densely welded, devitrified, partially silicified matrix; pumice, white, devitrified; phenocrysts, 5 to 7 percent, sanidine, plagioclase, biotite, and rose quartz; abundant grayish-red purple, rhyolitic-lithic fragments. Common siliceous-filled hairline fractures.

\section{Borehole number UE-25 UZN \#92}

Alluvium and colluvium, consisting of silt-sized to gravel-sized, subrounded to subangular, welded ash-flow tuff, rhyolitic-lava fragments, and basaltic lava fragments. Secondary carbonate coatings and discoloration of some fragments. Fresh surfaces on some fragments indicate they were chipped from larger fragments.

Tuffs, undifferentiated

Tuff, ash-flow, very light gray, partially welded, partially devitrified; pumice, white, partially devitrified, vapor-phase crystallization; phenocrysts, 10 to 12 percent, plagioclase, biotite, quartz, and alkali feldspar.

Tuff, ash-fall (?), silicified, moderate-brown to dark-yellowish-brown, well indurated; phenocrysts, 1 percent black biotite. Abundant, healed hairline fractures with clear and white siliceous filling material.

Lava flow, rhyolitic, light-bluish-gray, pale-yellowish-green, and light-gray, vitric; phenocrysts, less than 1 percent, biotite. Conspicuous concentric layering.

Lava flow, rhyolitic, medium-gray to dark-gray, and light-brownish-gray, vitric; phenocrysts, 1 percent, alkali feldspar and biotite. Abundant siliceous filled hairline fractures.
Depth to

bottom of intervai

(meters)
2.74

24.08

Total depth

17.68

Total depth 
Table 3. Lithologic logs of the neutron-access boreholes at Yucca Mountain--Continued

Stratigraphic and iithoiogic description
Borehole number USW UZ-N93
USW UZ-6 drill pad material
Paintbrush Tuff
Tiva Canyon Member
Tuff (caprock), ash-flow, very light gray, light-gray and light-brown, moderately welded,
devitrified; pumice, very light gray, brownish-gray and moderate-brown, devitrified,
vapor-phase crystallization;phenocrysts, 15 to 20 percent, sanidine, plagioclase, bronze
biotite and rare sphene. Calcareous and siliceous fracture fill material to 5.49 meters.
Tuff (upper cliff), ash-flow, light-gray and grayish-pink, moderately welded, devitrified;
pumice, white and medium-gray, devitrified, vapor-phase crystallization; phenocrysts,
10 to 12 percent, sanidine, plagioclase, biotite, rare sphene and rare hornblende.

\section{Borehole number USW UZ-N94}

Total depth

Paintbrush Tuff

Tiva Canyon Member

Tuff (caprock), ash-flow, very light gray and light-brown, moderately welded, devitrified; pumice, white, medium-light-gray and medium-dark-gray, devitrified, vesicular vaporphase crystallization; phenocrysts, 15 percent, sanidine, plagioclase, biotite and rare sphene.

Tuff (upper cliff), ash-flow, very light gray, light-gray and grayish-pink, moderately welded, devitrified; pumice, white and light-gray, devitrified, vesicular vapor-phase crystallization; phenocrysts, 10 to 12 percent, sanidine, plagioclase, biotite, rare sphene and rare hornblende. Lithophysal cavities with vapor-phase crystallization.

\section{Borehole number USW UZ-N95}

Paintbrush Tuff

Tiva Canyon Member

Tuff (caprock), ash-flow, very light gray and light-brown, moderately welded, devitrified; pumice, very light gray, light-gray and brownish-gray, vesicular vapor-phase crystallization; phenocrysts, 15 percent, sanidine, plagioclase, biotite and rare sphene and rare hornblende.

\section{Borehole number USW UZ-N96}

Alluvium and colluvium, consisting of silt-sized to boulder-sized, subrounded to subangular, moderately welded ash-flow tuff fragments (Tiva Canyon caprock). Some fragments have discolored surfaces, most have fresh angular surfaces.

Paintbrush Tuff

Tiva Canyon Member

Tuff (caprock), ash-flow, very light gray, light-gray, moderately welded, devitrified; pumice, white and brownish-gray, devitrified, vesicular vapor-phase crystallization, phenocrysts, 15 percent, sanidine, plagioclase, biotite and rare sphene and rare quartz.

Tuff (upper cliff), ash-flow, very light gray to light-gray, moderately welded, devitrified; pumice, very light gray, devitrified, vesicular vapor-phase crystallization; phenocrysts, 12 to 15 percent, sanidine, plagioclase, occasional bronze biotite and rare sphene. 
Table 3. Lithologic logs of the neutron-access boreholes at Yucca Mountain--Continued

Stratıgraphic and lithologic description
Borehole number USW UZ-N96-Continued
Tuff (upper lithophysal), ash-flow, light-gray to light-brownish-gray, moderately welded,
devitrified; pumice, very light gray, devitrified, vesicular vapor-phase crystallization;
pheno-crysts, 10 percent, sanidine, plagioclase and occasional bronze biotite; rare rhy-
olitic-lithic fragments. Manganese oxide dendrites in matrix.
Borehole number UE-25 UZN \#97
Alluvium and colluvium, consisting of silt-sized to gravel-sized, subrounded to subangular,
moderately to densely welded, ash-flow tuff fragments. Secondary carbonate coatings
and discoloration of some fragments. Fresh surfaces of some fragments indicate they
were derived from larger pieces. Interval from 15.85 to 17.68 meters consists of allu-
vium and colluvium, and weathered, fractured bedrock.

\section{Thlckness of Interval (meters)}

Depth to bottom of interval (meters)

Total depth

Paintbrush Tuff

Tiva Canyon Member

Tuff (lower lithophysal), ash-flow, grayish-red and moderate-reddish-brown to dark-reddish-brown, densely welded, devitrified; pumice, light-gray, devitrified; phenocrysts, 3 to 5 percent, sanidine and plagioclase. Sparse lithophysal cavities with vapor-phase crystallization. Occasional manganese oxide dendrites.

\section{Borehole number USW UZ-N98}

Alluvium and colluvium, consisting of fine-sand-sized to gravel-sized, densely welded Tiva Canyon tuff fragments.

Paintbrush Tuff

Tiva Canyon Member

Tuff (columnar), ash-flow, pale-red, densely welded, devitrified; pumice, grayish-red, devitrified, flattened 4:1; phenocrysts, 3 percent, sanidine, plagioclase and black biotite; occasional medium-light-gray and medium-gray rhyolitic-lithic fragments. Minor secondary carbonate in upper part of interval.

Tuff (columnar), ash-flow, pale-brown, moderately welded, devitrified; pumice, mediumlight-gray, devitrified; phenocrysts, 1 to 2 percent, sanidine, plagioclase and black biotite; occasional thyolitic-lithic fragments.

Tuff (shardy base), ash-flow, light-brown, moderately to partially welded, argillized; pumice, light-gray, moderate-red, argillized, devitrified; phenocrysts, 1 percent, sanidine, plagioclase and biotite; disseminated manganese oxide; occasional medium-gray and reddish-gray rhyolitic-lithic fragments; amber glass shards.

Tuff (shardy base), ash-flow, light-brown, partially welded, vitric; pumice, grayish-pink and pinkish-gray, vitric and argillized; phenocrysts, 1 percent, sanidine and plagioclase; sparse moderate-red rhyolitic-lithic fragments; black glass shards, common to abundant with depth. Unit becomes argillized at 13.72 meters with moderate-orange-pink pumice.

Total depth 
Table 3. Lithologic logs of the neutron-access boreholes at Yucca Mountain--Continued

\begin{tabular}{|c|c|c|}
\hline Stratigraphic and lithologic description & $\begin{array}{l}\text { Thickness of } \\
\text { Interval } \\
\text { (meters) }\end{array}$ & $\begin{array}{l}\text { Depth th } \\
\text { bottom of } \\
\text { Interva? } \\
\text { (meters) }\end{array}$ \\
\hline \multicolumn{3}{|l|}{ Borehole number USW UZ-N98-Continued } \\
\hline $\begin{array}{l}\text { Bedded tuff } \\
\text { Tuff, ash-fall, weathered, grayish-orange-pink to light-brown, nonwelded, vitric; pumice, } \\
\text { very pale orange and moderate-orange-pink, rounded; phenocrysts, } 3 \text { percent, sanidine } \\
\text { and plagioclase; sparse rhyolitic-lithic fragments. }\end{array}$ & 2.13 & 19.50 \\
\hline $\begin{array}{l}\text { Tuff, ash-fall, light-gray to grayish-orange-pink, nonwelded, vitric; pumice, light-gray and } \\
\text { very pale orange, vitric; phenocrysts, } 4 \text { to } 5 \text { percent, sanidine and plagioclase; occa- } \\
\text { sional rhyolitic-lithic fragments. }\end{array}$ & 0.91 & 20.41 \\
\hline $\begin{array}{l}\text { Tuff, ash-fall, weathered, very pale orange and grayish-orange, nonwelded, argillized; } \\
\text { pumice, white, vitric, argillized; phenocrysts, } 1 \text { percent, sanidine and plagioclase; occa- } \\
\text { sional rhyolitic-lithic fragments. }\end{array}$ & .91 & 21.32 \\
\hline $\begin{array}{l}\text { Tuff, ash-fall, white, nonwelded, vitric; pumice, white, vitric; phenocrysts, } 1 \text { percent, sani- } \\
\text { dine and plagioclase; common rhyolitic-lithic fragments. }\end{array}$ & .61 & 21.93 \\
\hline \multirow{2}{*}{$\begin{array}{l}\text { Yucca Mountain Member } \\
\text { Tuff, ash-flow, light-brownish-gray, nonwelded to partially welded, vitric; pumice, white to } \\
\text { very light gray, argillized; phenocrysts, } 1 \text { percent, sanidine and plagioclase; common } \\
\text { thyolitic-lithic fragments. }\end{array}$} & .91 & 22.86 \\
\hline & Total depth & 22.86 \\
\hline
\end{tabular}


Table 4. Results of laboratory analyses of hydrologic characteristics of drill cuttings from neutron-access boreh les [Depth is the midpoint of the drilled interval; A, alluvium/colluvium; B, bedrock; <, less than; --, no data]

\begin{tabular}{|c|c|c|c|c|c|c|c|c|}
\hline \multirow{2}{*}{$\begin{array}{c}\text { Neutron- } \\
\text { access } \\
\text { borehole } \\
\text { number }\end{array}$} & \multirow{2}{*}{$\begin{array}{c}\text { Depth } \\
\text { (meters) }\end{array}$} & \multirow{2}{*}{ Rock type } & \multicolumn{3}{|c|}{$\begin{array}{l}\text { Gravimetric water content } \\
\text { (grams per gram) }\end{array}$} & \multicolumn{3}{|c|}{$\begin{array}{l}\text { Water potential } \\
\text { (kilopascais) }\end{array}$} \\
\hline & & & Composite & Coarse & Fine & Composite & Coarse & Fine \\
\hline UE-25 & 0.9 & $\bar{A}$ & 0.038 & 0.034 & -- & - & $-1,000$ & - \\
\hline \multirow[t]{16}{*}{ UZN \#1 } & 1.5 & A & .038 & .041 & -- & -- & -600 & -- \\
\hline & 2.7 & A & .049 & .049 & - & -- & -290 & -- \\
\hline & 3.4 & A & .045 & .042 & -- & -- & -570 & -- \\
\hline & 4.0 & A & .049 & .045 & -- & -- & -400 & -- \\
\hline & 4.6 & A & .058 & .054 & .- & -- & -370 & -- \\
\hline & 5.2 & A & .049 & .043 & -- & -- & -460 & - \\
\hline & 5.8 & A & .053 & .052 & - & - & -380 & - \\
\hline & 6.4 & A & .019 & .062 & -- & -- & -290 & - \\
\hline & 7.0 & A & .057 & .059 & -- & -- & -370 & - \\
\hline & 7.6 & A & .061 & .064 & -- & -- & -450 & -- \\
\hline & 11.1 & B & .288 & -- & -- & -270 & -- & -- \\
\hline & 11.6 & B & .249 & -- & -- & -270 & -- & -- \\
\hline & 12.2 & B & .105 & -- & -- & $-1,000$ & -- & -- \\
\hline & 12.8 & B & .081 & -- & - & $-1,300$ & -- & -- \\
\hline & 14.0 & B & .088 & - & -- & -920 & - & -- \\
\hline & 14.8 & B & .104 & - & - & -720 & -- & - \\
\hline UE-25 & 1.5 & B & -- & .008 & -- & -- & $-29,000$ & -- \\
\hline \multirow[t]{9}{*}{ UZN \#2 } & 3.0 & B & -- & .011 & -- & - & $-19,000$ & -. \\
\hline & 4.6 & B & -- & .015 & -- & - & $-9,900$ & -- \\
\hline & 6.1 & B & -- & .023 & -- & -. & $-3,900$ & -- \\
\hline & 7.6 & B & -- & .011 & - & -- & $-17,000$ & -- \\
\hline & 9.1 & B & -- & .013 & - & -- & $-12,000$ & -- \\
\hline & 10.7 & B & -- & .010 & -- & -- & $-18,000$ & -- \\
\hline & 12.2 & B & - & .013 & -- & -- & $-13,000$ & - \\
\hline & 13.7 & B & - & .012 & -- & -- & $-15,000$ & - \\
\hline & 15.2 & B & -- & .012 & -- & -- & $-18,000$ & - \\
\hline UE-25 & 1.5 & A & .024 & .021 & -- & -- & $-3,700$ & -- \\
\hline \multirow[t]{2}{*}{ UZN \#3 } & 3.0 & B & .032 & .039 & -- & -- & $-2,500$ & -- \\
\hline & 4.6 & B & .020 & & & & & \\
\hline UE-25 & 1.5 & A & .023 & .015 & 0.032 & -- & $-4,400$ & $-4,100$ \\
\hline \multirow[t]{5}{*}{ UZN \#4 } & 3.0 & A & .028 & .027 & .042 & - & $-4,200$ & $-4,300$ \\
\hline & 4.6 & A & .017 & .031 & .023 & - & $-2,700$ & $-3,500$ \\
\hline & 6.1 & A & .047 & .037 & - & - & -160 & -250 \\
\hline & 7.6 & B & .050 & - & .064 & - & -140 & -280 \\
\hline & 9.1 & B & .016 & .018 & .013 & -- & $-9,000$ & - \\
\hline
\end{tabular}


Table 4. Results of laboratory analyses of hydrologic characteristics of drill cuttings from neutron-access boreholes--Ccntinued

\begin{tabular}{|c|c|c|c|c|c|c|c|c|}
\hline \multirow{2}{*}{$\begin{array}{l}\text { Neutron- } \\
\text { access } \\
\text { borehole } \\
\text { number }\end{array}$} & \multirow{2}{*}{$\begin{array}{l}\text { Depth } \\
\text { (meters) }\end{array}$} & \multirow{2}{*}{ Rock type } & \multicolumn{3}{|c|}{$\begin{array}{l}\text { Gravimetric water content } \\
\text { (grams per gram) }\end{array}$} & \multicolumn{3}{|c|}{$\begin{array}{l}\text { Water potentlal } \\
\text { (kilopascals) }\end{array}$} \\
\hline & & & Composite & Coarse & Fine & Composite & Coarse & Fine \\
\hline UE-25 & 1.5 & $\bar{A}$ & 0.021 & - & 0.022 & - & $-3,700$ & - \\
\hline \multirow[t]{11}{*}{ UZN \#5 } & 3.0 & A & .045 & .050 & .060 & - & $-3,300$ & -- \\
\hline & 4.6 & A & .037 & .017 & .043 & - & $-2,700$ & -- \\
\hline & 6.1 & A & .082 & .058 & -- & - & -600 & -610 \\
\hline & 7.6 & A & .050 & .055 & - & -- & -310 & -- \\
\hline & 9.1 & A & .039 & .034 & .049 & -- & -610 & -660 \\
\hline & 10.7 & A & .053 & .044 & .061 & - & -640 & $-4,400$ \\
\hline & 10.7 & A & -- & -- & - & - & -670 & -- \\
\hline & 12.2 & A & .053 & .043 & -- & -- & -510 & -250 \\
\hline & 13.7 & B & .021 & .022 & .020 & -- & $-4,800$ & $-5,000$ \\
\hline & 15.2 & B & .017 & .020 & .015 & -- & $-8,300$ & $-10,000$ \\
\hline & 15.2 & B & -- & -- & - & -- & $-6,600$ & -- \\
\hline UE-25 & 1.5 & A & .044 & .054 & .042 & -- & -290 & -380 \\
\hline \multirow[t]{11}{*}{ UZN \#6 } & 3.0 & A & .035 & .036 & .035 & -- & -600 & -820 \\
\hline & 3.0 & A & -- & -- & -- & -- & -590 & -- \\
\hline & 4.6 & A & .054 & .040 & .066 & - & -730 & -810 \\
\hline & 4.6 & A & -- & - & - & -- & -400 & - \\
\hline & 6.1 & A & .060 & .052 & .075 & -- & -250 & -260 \\
\hline & 7.6 & A & .041 & .039 & .058 & -- & -240 & -370 \\
\hline & 9.1 & A & .056 & .053 & .059 & -- & -270 & -270 \\
\hline & 10.7 & A & .053 & .052 & .060 & -. & -280 & -280 \\
\hline & 12.2 & A & .049 & .046 & .053 & -- & -220 & -350 \\
\hline & 13.7 & B & .016 & -- & - & $-6,600$ & -- & -- \\
\hline & 13.7 & B & .017 & - & - & -- & - & -- \\
\hline UE-25 & 1.5 & A & .034 & -- & - & - & -470 & - \\
\hline \multirow[t]{14}{*}{ UZN \#7 } & 1.5 & A & .034 & - & - & -- & - & - \\
\hline & 3.0 & A & .058 & - & -- & -- & -220 & -- \\
\hline & 3.0 & A & .062 & - & - & -- & - & - \\
\hline & 4.6 & A & .060 & - & - & -- & -290 & - \\
\hline & 4.6 & A & .062 & - & -- & -- & - & - \\
\hline & 6.1 & A & .060 & -- & -- & -. & -250 & - \\
\hline & 6.1 & A & .058 & -- & -- & -- & -90 & - \\
\hline & 6.7 & A & .061 & -- & -- & - & -420 & -- \\
\hline & 6.7 & A & .062 & -- & -- & - & -- & - \\
\hline & 7.3 & A & .058 & -- & -- & - & -280 & -- \\
\hline & 7.3 & A & .059 & -- & -- & - & -- & - \\
\hline & 7.9 & A & .055 & -- & -- & -. & -270 & -- \\
\hline & 7.9 & A & .056 & - & -- & -- & - & -- \\
\hline & 8.5 & A & .057 & -- & -- & - & -280 & -- \\
\hline
\end{tabular}


Table 4. Results of laboratory analyses of hydrologic characteristics of drill cuttings from neutron-access boreholes--Continued

\begin{tabular}{|c|c|c|c|c|c|c|c|c|}
\hline \multirow{2}{*}{$\begin{array}{c}\text { Neutron- } \\
\text { access } \\
\text { borehole } \\
\text { number }\end{array}$} & \multirow{2}{*}{$\begin{array}{l}\text { Depth } \\
\text { (meters) }\end{array}$} & \multirow{2}{*}{ Rock type } & \multicolumn{3}{|c|}{$\begin{array}{l}\text { Gravimetric water content } \\
\text { (grams per gram) }\end{array}$} & \multicolumn{3}{|c|}{$\begin{array}{l}\text { Water potential } \\
\text { (kilopascais) }\end{array}$} \\
\hline & & & Composite & Coarse & Fine & Composite & Coarse & Fine \\
\hline \multicolumn{9}{|l|}{ UE-25 } \\
\hline \multicolumn{9}{|c|}{ UZN \#7--Continued } \\
\hline & 8.5 & A & 0.058 & -- & - & - & - & - \\
\hline & 9.1 & A & .060 & -- & - & - & -340 & - \\
\hline & 9.1 & A & .064 & -- & - & - & - & - \\
\hline & 9.8 & A & .065 & -- & - & -- & -350 & - \\
\hline & 9.8 & $A$ & .066 & -- & - & - & - & - \\
\hline & 10.4 & A & .068 & - &.- & -- & -160 & - \\
\hline & 10.4 & A & .069 & -- & -- & - & - & - \\
\hline & 11.0 & A & .058 & -- & -- & - & -100 & - \\
\hline & 11.0 & A & .056 & -- & -- & - & - & - \\
\hline & 11.6 & $A$ & .072 & - & $-\cdot$ & - & -110 & - \\
\hline & 11.6 & A & .069 & - & -- & - & - & - \\
\hline & 12.2 & A & .062 & -- & -- & -- & -98 & - \\
\hline & 12.2 & A & .062 & -- & -- & - & - & - \\
\hline & 12.8 & B & .016 & -- & -- & -- & $-4,100$ & - \\
\hline & 12.8 & B & .017 & -- & -. & - & - & - \\
\hline & 13.4 & B & .016 & -. & -- & - & $-5,800$ & - \\
\hline & 13.4 & B & .015 & -- & -- & - & - & - \\
\hline UE-25 & 1.2 & A & .029 & -- & - & - & -690 & - \\
\hline \multirow[t]{21}{*}{ UZN \#8 } & 1.2 & A & .029 & -- & - & - & -- & - \\
\hline & 1.8 & A & .040 & -- & -- & - & -330 & - \\
\hline & 1.8 & A & .036 & -. & - & - & - & - \\
\hline & 2.4 & $\mathrm{~A}$ & .072 & -. & -- & - & -130 & - \\
\hline & 2.4 & A & .073 & -- & -- & - & - & - \\
\hline & 3.0 & $\mathrm{~A}$ & .045 & -- & -- & -- & -110 & - \\
\hline & 3.0 & A & .046 & -- & -- & - & - & - \\
\hline & 3.7 & A & .063 & -- & -- & -- & $<-50$ & - \\
\hline & 3.7 & A & .066 & -- & -- & - & - & - \\
\hline & 4.3 & A & .062 & -- & -- & -- & $<-50$ & -- \\
\hline & 4.3 & A & .064 & -- & -- & -- & - & - \\
\hline & 4.9 & A & .074 & -. & -- & -- & -240 & -. \\
\hline & 4.9 & A & .075 & -. & -- & - & - & - \\
\hline & 5.5 & A & .062 & -- & $-\cdot$ & - & -200 & -- \\
\hline & 5.5 & A & .063 & -. & -- & - & -- & -- \\
\hline & 6.1 & A & .057 & -- & -- & - & -190 & - \\
\hline & 6.1 & A & .055 & -- & -- & - & - & - \\
\hline & 6.7 & A & .060 & -- & -- & - & -180 & - \\
\hline & 6.7 & A & .060 & -- & - & - & - & - \\
\hline & 7.3 & A & .055 & -- & - & - & -110 & - \\
\hline & 7.3 & A & .056 & -- & -- & - & -. & -- \\
\hline
\end{tabular}


Table 4. Results of laboratory analyses of hydrologic characteristics of drill cuttings from neutron-access boreholes--Continued

\begin{tabular}{|c|c|c|c|c|c|c|c|c|}
\hline \multirow{2}{*}{$\begin{array}{l}\text { Neutron- } \\
\text { access } \\
\text { borehoie } \\
\text { number }\end{array}$} & \multirow{2}{*}{$\begin{array}{c}\text { Depth } \\
\text { (meters) }\end{array}$} & \multirow{2}{*}{ Rock type } & \multicolumn{3}{|c|}{$\begin{array}{l}\text { Gravimetric water content } \\
\text { (grams per gram) }\end{array}$} & \multicolumn{3}{|c|}{$\begin{array}{l}\text { Water potential } \\
\text { (kilopascais) }\end{array}$} \\
\hline & & & Composite & Coarse & Fine & Composite & Coarse & F'v \\
\hline \multicolumn{9}{|c|}{ UE-25 } \\
\hline \multicolumn{9}{|c|}{ UZN \#8--Continued } \\
\hline & 7.9 & A & 0.055 & -- & - & - & - & - \\
\hline & 7.9 & A & .055 & -- & - & - & -- & - \\
\hline & 8.5 & A & .062 & -- & -- & -- & - & -- \\
\hline & 8.5 & $A$ & .063 & -- & -- & - & -- & - \\
\hline & 9.1 & A & .058 & -- & -- & - & -- & - \\
\hline & 9.1 & A & .059 & -- & -- & -- & -- & - \\
\hline & 9.8 & A & .053 & -- & - & - & -- & -- \\
\hline & 9.8 & A & .053 & - & - & - & -- & - \\
\hline & 10.4 & A & .052 & - & - & - & -- & - \\
\hline & 10.4 & A & .054 & - & -- & -- & -- & - \\
\hline & 11.0 & A & .055 & - & - & - & -150 & -- \\
\hline & 11.0 & A & .048 & -- & - & $\cdots$ & -- & - \\
\hline & 11.6 & A & .050 & - & - & - & - & - \\
\hline & 11.6 & A & .045 & - & -- & -- & -- & -- \\
\hline & 12.2 & B & .035 & - & -- & -- & -410 & -- \\
\hline & 12.2 & B & .035 & - & - & - & -- & -- \\
\hline & 12.8 & B & .013 & - & - & -- & $-6,900$ & -- \\
\hline & 12.8 & B & .013 & -- & -- & -- & - & -- \\
\hline & 13.4 & B & .020 & -- & - & -- & $-4,800$ & -. \\
\hline & 13.4 & B & .021 & -- & -- & - & -- & -- \\
\hline UE-25 & 1.8 & A & .012 & -- & -- & - & $-2,600$ & -- \\
\hline \multirow[t]{18}{*}{ UZN \#9 } & 1.8 & A & .012 & -- & - & - & -- & - \\
\hline & 2.4 & A & .015 & -- & -- & -- & $-5,000$ & -- \\
\hline & 2.4 & A & .016 & -- & -- & -- & -- & -- \\
\hline & 3.0 & A & .056 & - & -- & -- & -320 & - \\
\hline & 3.0 & A & .059 & - & -- & - & -- & - \\
\hline & 3.7 & A & .051 & -- & - & - & -77 & - \\
\hline & 3.7 & A & .052 & -- & - & - & -. & -- \\
\hline & 4.3 & A & .052 & - & - & $\cdots$ & -600 & -. \\
\hline & 4.3 & A & .050 & -- & - & -- & -- & - \\
\hline & 4.9 & A & .048 & -- & -- & - & -340 & - \\
\hline & 4.9 & A & .052 & -- & - & $\cdots$ & -. & - \\
\hline & 5.5 & A & .043 & - & - & -- & -370 & - \\
\hline & 5.5 & A & .043 & -- & -- & -- & -- & -- \\
\hline & 6.1 & A & .041 & - & - & - & -290 & -- \\
\hline & 6.1 & A & .042 & - & -- & -- & -- & - \\
\hline & 6.7 & A & .040 & -- & - & -- & -500 & - \\
\hline & 6.7 & A & .042 & -- & -- & - & - & -- \\
\hline & 7.3 & A & .038 & -- & -- & -- & -520 & -- \\
\hline
\end{tabular}


Table 4. Results of laboratory analyses of hydrologic characteristics of drill cuttings from neutron-access borehol $3 s--C o n t i n u e d$

\begin{tabular}{|c|c|c|c|c|c|c|c|c|}
\hline \multirow{2}{*}{$\begin{array}{c}\text { Neutron- } \\
\text { access } \\
\text { borehole } \\
\text { number }\end{array}$} & \multirow{2}{*}{$\begin{array}{c}\text { Depth } \\
\text { (meters) }\end{array}$} & \multirow{2}{*}{ Rock type } & \multicolumn{3}{|c|}{$\begin{array}{l}\text { Gravimetrlc water content } \\
\text { (grams per gram) }\end{array}$} & \multicolumn{3}{|c|}{$\begin{array}{l}\text { Water potentlal } \\
\text { (kllopascals) }\end{array}$} \\
\hline & & & Composite & Coarse & Fine & Composite & Coarse & Fine \\
\hline \multicolumn{9}{|l|}{ UE-25 } \\
\hline \multicolumn{9}{|c|}{ UZN \#9-Continued } \\
\hline & 7.3 & A & 0.040 & -- & -- & - & - & - \\
\hline & 7.9 & A & .035 & - & - & -- & -580 & - \\
\hline & 7.9 & A & .035 & - & - & - & -- & - \\
\hline & 8.5 & A & .037 & -- & - & - & -380 & - \\
\hline & 8.5 & A & .038 & -- & - & -- & - & -- \\
\hline & 9.1 & A & .039 & -- & -. & -- & -460 & - \\
\hline & 9.1 & A & .039 & -- & - & - & - & - \\
\hline & 9.8 & A & .037 & -- & -- & - & -520 & - \\
\hline & 9.8 & A & .038 & - & -- & - & -- & - \\
\hline & 10.4 & A & .036 & -- & -- & -- & -550 & - \\
\hline & 10.4 & A & .037 & -- & -- & - & - & -- \\
\hline & 11.0 & B & .037 & - & -- & - & -660 & - \\
\hline & 11.0 & B & .038 & -- & -- & - & - & - \\
\hline & 11.6 & B & .016 & -. & -- & - & $-5,900$ & - \\
\hline & 11.6 & B & .016 & -- & -- & -- & - & - \\
\hline & 12.2 & B & .019 & - & -- & - & $-4,100$ & - \\
\hline & 12.2 & B & .020 & - & -- & - & - & - \\
\hline UE-25 & 4.0 & B & -- & 0.201 & $-\cdot$ & - & -620 & -- \\
\hline \multirow[t]{20}{*}{ UZN \#10 } & 6.9 & B & -- & -- & 0.167 & -- & -920 & -- \\
\hline & 7.9 & B & -- & -- & .184 & -- & -680 & - \\
\hline & 8.5 & B & - & .223 & .192 & -- & -720 & - \\
\hline & 9.0 & B & -- & - & .179 & -- & -690 & - \\
\hline & 9.4 & B & -- &. & .195 & -. & -630 & -- \\
\hline & 10.1 & B & -- & .214 & -- & -- & -730 & - \\
\hline & 10.5 & B & -- & .203 & - & -- & -830 & - \\
\hline & 11.0 & B & -- & .207 & -- & -- & -680 & -- \\
\hline & 11.6 & B & -- & .175 & -- & -- & -660 & - \\
\hline & 12.2 & B & -- & -- & .112 & - & -780 & - \\
\hline & 12.8 & B & -- & .127 & -- & -- & -720 & - \\
\hline & 13.4 & B & -- & .131 & -- & - & -660 & - \\
\hline & 14.0 & B & -- & .140 & -. & .- & -810 & -- \\
\hline & 14.6 & B & -- & .138 & -- & -- & -730 & - \\
\hline & 15.2 & B & -. & .153 & -. & -- & -780 & -- \\
\hline & 15.8 & B & -. & .161 & -- & -- & -560 & -. \\
\hline & 16.5 & B & -- & .167 & -- & -- & -670 & -- \\
\hline & 17.1 & B & -- & .154 & -- & - & -730 & -- \\
\hline & 17.7 & B & -- & .161 & -- & - & -520 & -- \\
\hline & 18.3 & B & -- & .154 & -- & - & -540 & -- \\
\hline
\end{tabular}


Table 4. Results of laboratory analyses of hydrologic characteristics of drill cuttings from neutron-access boreholes--Continued

\begin{tabular}{|c|c|c|c|c|c|c|c|c|}
\hline \multirow{2}{*}{$\begin{array}{l}\text { Neutron- } \\
\text { access } \\
\text { borehole } \\
\text { number }\end{array}$} & \multirow{2}{*}{$\begin{array}{l}\text { Depth } \\
\text { (meters) }\end{array}$} & \multirow{2}{*}{ Rock type } & \multicolumn{3}{|c|}{$\begin{array}{l}\text { Gravimetric water content } \\
\text { (grams per gram) }\end{array}$} & \multicolumn{3}{|c|}{$\begin{array}{l}\text { Water potential } \\
\text { (kllopascals) }\end{array}$} \\
\hline & & & Composite & Coarse & Fine & Composite & Coarse & $F \times A$ \\
\hline \multicolumn{9}{|l|}{ UE-25 } \\
\hline \multicolumn{9}{|c|}{ UZN \#10--Continued } \\
\hline & 18.9 & B & -- & 0.149 & - & -- & -490 & -- \\
\hline & 19.5 & B & -- & .139 & - & -- & -490 & -- \\
\hline & 20.1 & B & -- & .131 & -- & -- & -530 & -- \\
\hline & 20.7 & B & -- & .127 & - & - & -490 & -- \\
\hline & 21.3 & B & -- & .122 & - & - & -650 & -- \\
\hline & 21.9 & B & - & .121 & -- & - & -580 & - \\
\hline & 22.4 & B & - & -- & .109 & - & -620 & -- \\
\hline & 22.7 & B & - & - & .106 & - & -640 & - \\
\hline & 23.0 & B & -- & .108 & .102 & -- & -690 & - \\
\hline & 23.3 & B & -- & .102 & - & - & -640 & -- \\
\hline & 23.6 & B & -- & .104 & - & - & -710 & -- \\
\hline & 23.9 & B & -- & - & .101 & - & -520 & - \\
\hline & 24.2 & B & -- & - & .100 & - & -560 & - \\
\hline & 24.5 & B & -- & - & .100 & - & -510 & -- \\
\hline & 24.8 & B & -- & .111 & - & -- & -430 & -- \\
\hline & 25.1 & B & -- & - & .087 & -- & -480 & - \\
\hline & 25.5 & B & -- & .106 & - & -- & -620 & -- \\
\hline & 25.8 & B & - & - & .084 & -- & -730 & - \\
\hline & 26.1 & B & -- & .127 & - & -- & -690 & - \\
\hline & 26.4 & B & -- & .121 & -- & -- & -680 & - \\
\hline & 26.7 & B & - & .124 & - & -- & -620 & -- \\
\hline & 27.0 & B & -- & .153 & - &.- & -650 & - \\
\hline & 27.3 & B & -- & - & .129 & -. & -460 & - \\
\hline & 27.6 & B & -- & .113 & - & - & -560 & - \\
\hline & 27.9 & B & -- & -- & .148 & -- & -470 & - \\
\hline & 28.2 & B & - & .148 & - & - & -420 & - \\
\hline & 28.5 & B & -- & - & .101 & -- & -450 & -- \\
\hline UE-25 & 0.6 & A & 0.069 & -- & - & -- & -170 & - \\
\hline \multirow[t]{12}{*}{ UZN \#12 } & .6 & A & .071 & -- & - & -- & - & - \\
\hline & 1.2 & A & .070 & - & - & -- & -170 & - \\
\hline & 1.2 & A & .071 & - & - & -- & - & - \\
\hline & 1.8 & A & .054 & -- & - & - & -210 & - \\
\hline & 1.8 & $\mathrm{~A}$ & .055 & - & -. & - & -. & -. \\
\hline & 2.4 & $A$ & .065 & -- & -- & -- & -- & - \\
\hline & 2.4 & A & .058 & -- & -- & - & -- & - \\
\hline & 3.0 & A & .049 & -- & -- & -- & -400 & -- \\
\hline & 3.0 & A & .047 & -- & - & -- & -- & -- \\
\hline & 3.7 & $A$ & .037 & - & -- & -- & - & -- \\
\hline & 3.7 & A & .040 & - & -- & - & -- & - \\
\hline & 4.3 & $\mathrm{~A}$ & .044 & - & - & -- & -300 & -- \\
\hline
\end{tabular}


Table 4. Results of laboratory analyses of hydrologic characteristics of drill cuttings from neutron-access boreholes--Continued

\begin{tabular}{|c|c|c|c|c|c|c|c|c|}
\hline \multirow{2}{*}{$\begin{array}{c}\text { Neutron- } \\
\text { access } \\
\text { borehoie } \\
\text { number }\end{array}$} & \multirow{2}{*}{$\begin{array}{c}\text { Depth } \\
\text { (meters) }\end{array}$} & \multirow{2}{*}{ Rock type } & \multicolumn{3}{|c|}{$\begin{array}{l}\text { Gravimetric water content } \\
\text { (grams per gram) }\end{array}$} & \multicolumn{3}{|c|}{$\begin{array}{l}\text { Water potentiai } \\
\text { (kliopascais) }\end{array}$} \\
\hline & & & Composite & Coarse & Fine & Composite & Coarse & Fine \\
\hline \multicolumn{9}{|l|}{ UE-25 } \\
\hline \multicolumn{9}{|c|}{ UZN \#12--Continued } \\
\hline & 4.3 & A & 0.045 & -- & -- & - & - & - \\
\hline & 4.9 & A & .042 & -- & -- & - & - & - \\
\hline & 4.9 & A & .042 & -- & -- & - & -- & - \\
\hline & 5.5 & A & .036 & -- & -- & - & -280 & - \\
\hline & 5.5 & A & .036 & -- & -- & - & -- & - \\
\hline & 6.1 & A & .036 & $\cdots$ & -- & -- & -- & - \\
\hline & 6.1 & A & .041 & - & -- & -- & - & - \\
\hline & 6.7 & A & .054 & -- & -- & - & -290 & - \\
\hline & 6.7 & A & .051 & -- & - & - & - & - \\
\hline & 7.3 & A & .049 & -- & -- & - & -- & -- \\
\hline & 7.3 & A & .052 & -- & -- & - & - & - \\
\hline & 7.9 & A & .046 & -- & - & - & -280 & - \\
\hline & 7.9 & A & .057 & -- & - & - & - & - \\
\hline & 8.5 & A & .041 & -- & -- & - & - & - \\
\hline & 8.5 & A & .041 & -- & -- & -- & - & - \\
\hline & 9.1 & A & .054 & - & -- & -- & -260 & - \\
\hline & 9.1 & A & .051 & - & -- & - & -- & - \\
\hline & 9.8 & A & .048 & - & -- & -- & -- & - \\
\hline & 9.8 & A & .050 & - & - & -. & -- & - \\
\hline & 10.4 & A & .025 & -- & - & -. & -190 & - \\
\hline & 10.4 & A & .037 & - & -- & -- & -- & -- \\
\hline & 11.0 & A & .052 & - & - & -- & - & -- \\
\hline & 11.6 & A & .035 & - & $-\cdot$ & -- & -270 & -. \\
\hline & 11.6 & A & .040 & -- & -- & -- & - & -- \\
\hline & 12.2 & A & .037 & -- & - & - & - & - \\
\hline & 12.2 & A & .032 & -- & - & - & - & - \\
\hline & 12.8 & A & .031 & -- & - & - & -830 & - \\
\hline & 12.8 & A & .033 & -- & - & - & -- & - \\
\hline & 13.4 & A & .038 & - & - & - & - & - \\
\hline & 13.4 & A & .039 & -- & -- & - & - & - \\
\hline & 14.0 & B & .034 & -- & -- & - & -500 & - \\
\hline & 14.0 & B & .037 & -- & -- & - & -- & -- \\
\hline & 14.6 & B & .018 & -- & -- & - & - & - \\
\hline & 14.6 & B & .021 & - & - & - & - & -- \\
\hline & 15.2 & B & .020 & -- & - & -- & $-2,000$ & - \\
\hline & 15.2 & B & .020 & -- & -- & -- & -- & - \\
\hline UE-25 & 0.6 & A & .012 & - & - & -- & $-11,000$ & - \\
\hline \multirow[t]{3}{*}{ UZN \#13 } & .6 & A & .012 & - & - & - & -- & - \\
\hline & 1.2 & A & .017 & -- & -- & - & $-2,200$ & - \\
\hline & 1.2 & A & .017 & - & -- & -- & -- & - \\
\hline
\end{tabular}


Table 4. Results of laboratory analyses of hydrologic characteristics of drill cuttings from neutron-access boreholes--Continued

\begin{tabular}{|c|c|c|c|c|c|c|c|c|}
\hline \multirow{2}{*}{$\begin{array}{c}\text { Neutron- } \\
\text { access } \\
\text { borehole } \\
\text { number }\end{array}$} & \multirow{2}{*}{$\begin{array}{c}\text { Depth } \\
\text { (meters) }\end{array}$} & \multirow{2}{*}{ Rock typo } & \multicolumn{3}{|c|}{$\begin{array}{l}\text { Gravimetric water content } \\
\text { (grams per gram) }\end{array}$} & \multicolumn{3}{|c|}{$\begin{array}{l}\text { Water potential } \\
\text { (kllopascals) }\end{array}$} \\
\hline & & & Composite & Coarse & Fine & Composite & Coarse & Fire \\
\hline \multicolumn{9}{|c|}{ UE-25 } \\
\hline \multicolumn{9}{|c|}{ UZN \#13-Continued } \\
\hline & 1.8 & A & 0.022 & - & - & -- & $-3,100$ & - \\
\hline & 1.8 & A & .027 & - & - & -- & -- & -- \\
\hline & 2.4 & A & .035 & -- & -- & -- & -580 & -- \\
\hline & 2.4 & A & .036 & -- & - & -- & -- & -- \\
\hline & 3.0 & A & .064 & -- & -- & -- & -170 & -- \\
\hline & 3.0 & A & .066 & -- & -- & - & -- & -- \\
\hline & 3.7 & A & .058 & -- & -- & -- & -180 & -- \\
\hline & 3.7 & A & .060 & - & -- & -- & - & - \\
\hline & 4.3 & A & .059 & -- & - & - & -100 & -. \\
\hline & 4.3 & A & .060 & - & -- & - & -- & - \\
\hline & 4.9 & A & .048 & - & - & -- & -130 & - \\
\hline & 4.9 & A & .051 & - & - & -- & -- & - \\
\hline & 5.5 & A & .056 & - & -- & -- & -86 & - \\
\hline & 5.5 & $\mathbf{A}$ & .058 & -- & -. & -- & -- & - \\
\hline & 6.1 & A & .056 & - & - & .. & -180 & -. \\
\hline & 6.1 & A & .057 & - & - & -. & -- & $\ldots$ \\
\hline & 6.7 & A & .059 & -- & - & - & -270 & - \\
\hline & 6.7 & A & .056 & -. & - & -. & - & - \\
\hline & 7.3 & $\mathbf{A}$ & .059 & -- & -- & - & -130 & - \\
\hline & 7.3 & A & .060 & -- & -- & - & -- & -- \\
\hline & 7.9 & A & .055 & - & - & -- & -330 & - \\
\hline & 7.9 & A & .056 & -- & -- & - & -- & - \\
\hline & 8.5 & A & .059 & - & - & - & -160 & -- \\
\hline & 8.5 & A & .057 & - & - & -- & -- & - \\
\hline & 9.1 & A & .056 & -- & -- & -- & -200 & -- \\
\hline & 9.1 & A & .057 & -- & -- & - & -- & -- \\
\hline & 9.8 & A & .060 & - & -- & -- & -130 & -- \\
\hline & 9.8 & A & .058 & - & -- & -- & -. & -- \\
\hline & 10.4 & A & .054 & - & - & -- & -160 & - \\
\hline & 10.4 & A & .057 & -- & - & -- & - & -. \\
\hline & 11.0 & A & .052 & -- & -- & -- & -190 & -- \\
\hline & 11.0 & $\mathbf{A}$ & .053 & - & -- & -- & -. & -- \\
\hline & 11.6 & $\mathbf{A}$ & .083 & -- & -- & -- & $<-50$ & - \\
\hline & 11.6 & A & .091 & -. & - & -- & - & -. \\
\hline & 12.2 & A & .095 & -. & - & - & $<-50$ & -- \\
\hline & 12.2 & A & .088 & -- & - & - & -- & - \\
\hline & 12.8 & A & .062 & - & - & -- & -150 & - \\
\hline & 12.8 & A & .067 & - & - & -- & -- & -- \\
\hline & 13.4 & A & .094 & -- & - & -- & -120 & -- \\
\hline & 13.4 & A & .094 & -- & - & -- & -- & -- \\
\hline & 14.0 & A & .071 & -- & - & .. & -. & -. \\
\hline
\end{tabular}


Table 4. Results of laboratory analyses of hydrologic characteristics of drill cuttings from neutron-access boreho' 95 --Continued

\begin{tabular}{|c|c|c|c|c|c|c|c|c|}
\hline \multirow{2}{*}{$\begin{array}{l}\text { Neutron- } \\
\text { access } \\
\text { borehole } \\
\text { number }\end{array}$} & \multirow{2}{*}{$\begin{array}{l}\text { Depth } \\
\text { (meters) }\end{array}$} & \multirow{2}{*}{ Rock type } & \multicolumn{3}{|c|}{$\begin{array}{l}\text { Gravimetrlc water content } \\
\text { (grams per gram) }\end{array}$} & \multicolumn{3}{|c|}{$\begin{array}{l}\text { Water potential } \\
\text { (kllopascals) }\end{array}$} \\
\hline & & & Composite & Coarse & Fine & Composite & Coarse & Fine \\
\hline \multicolumn{9}{|c|}{ UE-25 } \\
\hline \multicolumn{9}{|c|}{ UZN \#13--Continued } \\
\hline & 14.0 & A & 0.071 & - & -- & -- & -- & - \\
\hline & 14.6 & B & .033 & -- & -- & - & -180 & - \\
\hline & 14.6 & B & .035 & - & -- & - & - & -- \\
\hline & 15.2 & B & .016 & -- & -- & -- & -- & - \\
\hline & 15.2 & B & .017 & -- & -- & -- & - & - \\
\hline & 15.8 & B & .030 & -- & -- & -- & -140 & - \\
\hline & 15.8 & B & .028 & - & -- & -- & -- & - \\
\hline & 16.5 & B & .022 & -- & -- & -- & -- & - \\
\hline & 16.5 & B & .023 & -- & -- & -- & - & -- \\
\hline & 17.1 & B & .028 & -- & -- & - & -290 & -- \\
\hline & 17.1 & B & .029 & -- & -- & - & - & - \\
\hline & 17.7 & B & .031 & -- & -- & - & - & - \\
\hline & 17.7 & B & .037 & -- & -- & - & - & - \\
\hline & 18.3 & B & .024 & -- & -- & - & -400 & - \\
\hline & 18.3 & B & .022 & -- & -- & - & - & - \\
\hline & 18.9 & B & .014 & -- & -- & - & - & - \\
\hline & 18.9 & B & .015 & -- & -- & -- & - & - \\
\hline & 19.5 & B & .019 & - & - & - & -300 & -- \\
\hline & 19.5 & B & .017 & -- & - & - & -- & -- \\
\hline UE-25 & 0.6 & A & .024 & -- & -- & - & $-4,000$ & -- \\
\hline \multirow[t]{20}{*}{ UZN \#14 } & .6 & A & .041 & -- & -- & - & -- & - \\
\hline & 1.2 & A & .016 & -- & -- & - & -- & -- \\
\hline & 1.2 & A & .018 & - & - & - & - & -- \\
\hline & 1.8 & A & .024 & -- & -- & -- & $-3,000$ & - \\
\hline & 1.8 & A & .027 & - & -- & -- & $-1,300$ & - \\
\hline & 2.4 & A & .020 & -- & -- & -- & -- & - \\
\hline & 2.4 & A & .020 & -- & -- & - & -- & - \\
\hline & 3.0 & A & .019 & -- & -- & -- & $-8,100$ & - \\
\hline & 3.0 & A & .021 & -- & -- & -- & $-4,100$ & - \\
\hline & 3.7 & A & .020 & -- & -- & -- & - & -- \\
\hline & 3.7 & A & .021 & -- & - & -- & - & -- \\
\hline & 4.3 & A & .024 & -- & -- & -- & $-4,100$ & -- \\
\hline & 4.3 & A & .024 & -- & -- & -- & $-2,400$ & - \\
\hline & 4.9 & A & .022 & -- & - & - & -- & - \\
\hline & 4.9 & A & .022 & -- & -- & -- & - & -- \\
\hline & 5.5 & A & .030 & -- & -- & -- & $-2,000$ & - \\
\hline & 5.5 & A & .027 & -- & -- & -- & $-1,400$ & -- \\
\hline & 6.1 & A & .032 & -- & -- & - & -- & -- \\
\hline & 6.1 & A & .031 & -- & - & - & - & -. \\
\hline & 6.7 & A & .024 & -- & - & - & $-1,400$ & -- \\
\hline
\end{tabular}


Table 4. Results of laboratory analyses of hydrologic characteristics of drill cuttings from neutron-access boreholes--Cortinued

\begin{tabular}{|c|c|c|c|c|c|c|c|c|}
\hline \multirow{2}{*}{$\begin{array}{l}\text { Neutron- } \\
\text { access } \\
\text { borehole } \\
\text { number }\end{array}$} & \multirow{2}{*}{$\begin{array}{l}\text { Depth } \\
\text { (meters) }\end{array}$} & \multirow{2}{*}{ Rock type } & \multicolumn{3}{|c|}{$\begin{array}{l}\text { Gravimetric water content } \\
\text { (grams per gram) }\end{array}$} & \multicolumn{3}{|c|}{$\begin{array}{l}\text { Water potential } \\
\text { (kilopascals) }\end{array}$} \\
\hline & & & Composite & Coarse & Fine & Composite & Coarse & Fine \\
\hline \multicolumn{9}{|l|}{ UE-25 } \\
\hline \multicolumn{9}{|c|}{ UZN \#14--Continued } \\
\hline & 6.7 & A & 0.025 & - & -- & -- & -- & -- \\
\hline & 7.3 & A & .026 & -- & -- & -- & -- & -- \\
\hline & 7.3 & A & .028 & - & - & -- & -- & -- \\
\hline & 7.9 & A & .029 & -- & - & -- & -670 & -- \\
\hline & 7.9 & A & .031 & -- & -- & - & -- & -- \\
\hline & 8.5 & A & .038 & -- & -- & -- & -- & -- \\
\hline & 8.5 & A & .037 & -- & -- & -- & -- & -- \\
\hline & 9.1 & A & .036 & -- & -- & -- & -450 & - \\
\hline & 9.1 & A & .037 & -- & - & -- & - & -- \\
\hline & 9.8 & A & .034 & -- & - & -- & -- & -- \\
\hline & 9.8 & A & .036 & -- & -- & -- & -- & -- \\
\hline & 10.4 & A & .034 & -- & -- & -- & -470 & -- \\
\hline & 10.4 & A & .033 & -- & - & -- & -- & -- \\
\hline & 11.0 & A & .038 & -- & - & -- & - & -- \\
\hline & 11.0 & A & .039 & -- & - & -- & - & -- \\
\hline & 11.6 & A & .040 & -- & - & -- & -430 & -- \\
\hline & 11.6 & A & .039 & - & - & -- & - & - \\
\hline & 12.2 & A & .036 & - & - & -- & - & - \\
\hline & 12.2 & A & .035 & - & -- & -- & -- & - \\
\hline & 12.8 & A & .038 & - & - & -- & -500 & - \\
\hline & 12.8 & A & .039 & -- & - & -- & - & -- \\
\hline & 13.4 & A & .036 & -- & - & -- & -- & -- \\
\hline & 13.4 & A & .037 & - & - & - & - & -- \\
\hline & 14.0 & B & .042 & - & -- & -- & -760 & - \\
\hline & 14.0 & B & .035 & - & - & -- & -- & - \\
\hline & 14.6 & B & .045 & - & -- & -- & -- & -- \\
\hline & 14.6 & B & .043 & -- & -- & -- & -- & - \\
\hline & 15.2 & B & .039 & - & -- & -- & -910 & -- \\
\hline UE-25 & 0.3 & A & -- & 0.016 & -- & -- & $-40,000$ & -- \\
\hline \multirow[t]{11}{*}{ UZN \#19 } & .8 & A & -- & -- & -- & -- & $-12,000$ & -- \\
\hline & 1.1 & A & -- & .021 & -- & -- & $-6,700$ & - \\
\hline & 1.4 & A & -- & .024 & -. & -- & $-4,200$ & -- \\
\hline & 1.7 & A & -- & .025 & -- & -- & $-4,300$ & -- \\
\hline & 2.1 & A & -- & .038 & -- & -. & -850 & -- \\
\hline & 2.6 & A & - & .056 & - & -- & -750 & -- \\
\hline & 2.9 & A & -- & .057 & - & -- & -760 & -- \\
\hline & 3.2 & A &.- & .054 & - & -- & -730 & -- \\
\hline & 3.7 & A & -- & .058 & -- & -- & -680 & -- \\
\hline & 4.1 & A & -- & .056 & -- & -- & -740 & -- \\
\hline & 4.4 & A & -- & .068 & -- & -- & -520 & - \\
\hline
\end{tabular}


Table 4. Results of laboratory analyses of hydrologic characteristics of drill cuttings from neutron-access borehcles--Continued

\begin{tabular}{|c|c|c|c|c|c|c|c|c|}
\hline \multirow{2}{*}{$\begin{array}{c}\text { Neutron- } \\
\text { access } \\
\text { borehole } \\
\text { number }\end{array}$} & \multirow{2}{*}{$\begin{array}{c}\text { Depth } \\
\text { (meters) }\end{array}$} & \multirow{2}{*}{ Rock type } & \multicolumn{3}{|c|}{$\begin{array}{l}\text { Gravimetric water content } \\
\text { (grams per gram) }\end{array}$} & \multicolumn{3}{|c|}{$\begin{array}{l}\text { Water potential } \\
\text { (kilopascais) }\end{array}$} \\
\hline & & & Composite & Coarse & Fine & Composite & Coarse & Fine \\
\hline \multicolumn{9}{|c|}{ UE-25 } \\
\hline \multicolumn{9}{|c|}{ UZN \#19--Continued } \\
\hline & 4.7 & A & -- & 0.065 & -- & - & -500 & - \\
\hline & 5.2 & A & -- & .050 & - & - & -630 & - \\
\hline & 5.6 & $\mathbf{A}$ & -- & .049 & -- & - & -740 & - \\
\hline & 5.9 & $\mathbf{A}$ & -- & .050 & - & - & -720 & - \\
\hline & 6.2 & $\mathbf{A}$ & - & .048 & -- & - & -530 & - \\
\hline & 6.7 & $\mathbf{A}$ & -- & .046 & - & - & -730 & - \\
\hline & 7.2 & B & - & .038 & -- & - & $-2,000$ & -- \\
\hline & 7.5 & B & - & .020 & - & - & $-8,300$ & -- \\
\hline & 7.8 & B & - & .029 & - & - & $-6,000$ & - \\
\hline & 8.2 & B & -- & .027 & -- & - & $-4,000$ & - \\
\hline & 8.7 & B & - & .036 & - & - & $-1,200$ & - \\
\hline & 9.0 & B & -- & .038 & -- & - & $-1,200$ & - \\
\hline & 9.3 & B & - & .039 & - & - & -990 & - \\
\hline & 9.6 & B & -- & .030 & -- & -- & $-2,500$ & - \\
\hline & 9.9 & B & -- & .029 & -- & - & $-2,700$ & - \\
\hline & 10.4 & B & -- & .029 & - & - & $-1,600$ & - \\
\hline & 10.8 & B & - & .033 & -- & - & $-1,200$ & - \\
\hline & 11.1 & B & - & .040 & -. & - & -740 & - \\
\hline & 11.4 & B & - & .047 & - & - & -740 & - \\
\hline & 11.7 & B & -- & .041 & - & -- & -620 & - \\
\hline & 12.0 & B & - & .045 & - & - & -650 & - \\
\hline UE-25 & 0.3 & A & -- & .008 & -- & - & $-17,000$ & - \\
\hline \multirow[t]{18}{*}{ UZN \#21 } & .8 & A & - & .011 & - & - & $-11,000$ & - \\
\hline & 1.1 & A & - & .021 & -- & -- & $-18,000$ & - \\
\hline & 1.4 & A & - & .011 & -- & -- & $-14,000$ & - \\
\hline & 1.7 & A & - & .017 & -- & - & $-18,000$ & -. \\
\hline & 2.1 & A & -- & .017 & - & - & $-7,400$ & - \\
\hline & 2.6 & A & -- & .029 & -- & - & $-1,700$ & - \\
\hline & 2.9 & A & - & .025 & -- & - & $-2,400$ & - \\
\hline & 3.2 & A & - & .025 & -- & - & $-3,100$ & - \\
\hline & 3.7 & A & -- & .030 & -- & - & $-2,500$ & -- \\
\hline & 4.1 & A & - & .024 & -- & - & $-5,700$ & - \\
\hline & 4.4 & A & - & .020 & -- & -- & $-6,300$ & - \\
\hline & 4.7 & $\mathbf{A}$ & -- & .014 & - & - & $-8,800$ & - \\
\hline & 5.2 & A & -- & .015 & - & - & $-11,000$ & -- \\
\hline & 5.6 & $\mathbf{A}$ & - & .019 & - & - & $-6,700$ & - \\
\hline & 5.9 & $\mathbf{A}$ & - & .017 & -. & -- & $-8,500$ & - \\
\hline & 6.2 & A & $\cdots$ & .015 & -- & - & $-9,600$ & - \\
\hline & 6.7 & $\mathbf{A}$ & $\cdots$ & .017 & - & - & $-9,900$ & - \\
\hline & 7.2 & A & -. & .017 & - & - & $-17,000$ & - \\
\hline
\end{tabular}


Table 4. Results of laboratory analyses of hydrologic characteristics of drill cuttings from neutron-access boreholes--Continued

\begin{tabular}{|c|c|c|c|c|c|c|c|c|}
\hline \multirow{2}{*}{$\begin{array}{c}\text { Neutron- } \\
\text { access } \\
\text { borehole } \\
\text { number }\end{array}$} & \multirow{2}{*}{$\begin{array}{l}\text { Depth } \\
\text { (meters) }\end{array}$} & \multirow{2}{*}{ Rock type } & \multicolumn{3}{|c|}{$\begin{array}{l}\text { Gravimetrlc water content } \\
\text { (grams per gram) }\end{array}$} & \multicolumn{3}{|c|}{$\begin{array}{l}\text { Water potentlal } \\
\text { (kllopascals) }\end{array}$} \\
\hline & & & Composite & Coarse & Fine & Composite & Coarse & F're \\
\hline \multicolumn{9}{|l|}{ UE-25 } \\
\hline \multicolumn{9}{|c|}{ UZN \#21--Continued } \\
\hline & 7.5 & $\mathbf{A}$ & -- & 0.020 & - & -- & $-11,000$ & - \\
\hline & 7.8 & $\mathbf{A}$ & -- & .019 & - & -- & $-8,200$ & - \\
\hline & 8.2 & A & - & .023 & - & - & $-6,500$ & -- \\
\hline & 8.7 & B & - & .023 & - & - & $-5,300$ & -- \\
\hline & 9.0 & B & -- & .028 & - & -- & $-3,200$ & - \\
\hline & 9.3 & B & -- & .029 & - & -- & $-4,600$ & - \\
\hline & 9.6 & B & -- & .023 & -- & -- & $-5,500$ & -- \\
\hline & 9.9 & B & - & .033 & -- & -- & $-3,100$ & - \\
\hline & 10.2 & B & -- & .033 & - & -- & $-2,500$ & -- \\
\hline & 10.5 & B & -- & .032 & - & -- & $-2,500$ & -- \\
\hline & 10.8 & B & - & .031 & - & - & $-3,200$ & -- \\
\hline & 11.1 & B & - & .030 & - & -- & $-2,800$ & -- \\
\hline & 11.4 & B & - & .029 & - & -- & $-3,900$ & -- \\
\hline & 11.7 & B & -- & .029 & - & - & $-6,200$ & -- \\
\hline & 12.0 & B & -- & .028 & - & -- & $-6,400$ & -- \\
\hline UE-25 & 0.3 & A & - & .056 & -- & - & -680 & - \\
\hline \multirow[t]{24}{*}{$\mathrm{UZN} \# 22$} & .8 & A & - & .025 & - & - & $-5,000$ & - \\
\hline & 1.1 & A & -- & .016 & - & -- & $-15,000$ & -- \\
\hline & 1.4 & A & -- & .019 & - & -- & $-6,000$ & - \\
\hline & 1.7 & A & -- & .019 & - & -- & $-8,800$ & - \\
\hline & 2.1 & A & -- & .017 & - & -- & $-7,800$ & -- \\
\hline & 2.6 & A & -- & .023 & - & - & $-5,500$ & - \\
\hline & 2.9 & A & -- & .028 & - & - & $-5,900$ & -- \\
\hline & 3.2 & A & -- & .027 & -- & -- & $-5,400$ & -- \\
\hline & 3.5 & A & - & .024 & - & - & $-5,200$ & -- \\
\hline & 3.8 & A & - & .063 & - & - & -780 & -- \\
\hline & 4.1 & A & - & .054 & - & - & -740 & -- \\
\hline & 4.4 & A & -- & .054 & - & -- & -590 & - \\
\hline & 4.7 & A & -- & .047 & -- & - & -550 & - \\
\hline & 5.0 & A & -- & .069 & -- & -- & -510 & -- \\
\hline & 5.3 & A & -- & .051 & - & -- & -570 & - \\
\hline & 5.6 & A & -- & .044 & - & -- & -670 & - \\
\hline & 5.9 & A & -- & .037 & - & - & -640 & - \\
\hline & 6.2 & B & -- & .028 & - &.- & $-2,700$ & - \\
\hline & 6.6 & B & - & .035 & - & - & $-1,700$ & - \\
\hline & 6.9 & B & - & .026 & - & -- & $-4,500$ & -- \\
\hline & 7.2 & B & - & .028 & -. & -- & $-4,200$ & -- \\
\hline & 7.5 & B & - & .027 & -- & - & $-6,800$ & -- \\
\hline & 7.8 & B & -- & .027 & -- & -- & $-6,400$ & -- \\
\hline & 8.1 & B & -- & .026 & -- & -- & $-8,100$ & -- \\
\hline
\end{tabular}


Table 4. Results of laboratory analyses of hydrologic characteristics of drill cuttings from neutron-access boreho'ss--Continued

\begin{tabular}{|c|c|c|c|c|c|c|c|c|}
\hline \multirow{2}{*}{$\begin{array}{c}\text { Neutron- } \\
\text { access } \\
\text { borehole } \\
\text { number }\end{array}$} & \multirow{2}{*}{$\begin{array}{c}\text { Depth } \\
\text { (meters) }\end{array}$} & \multirow{2}{*}{ Rock type } & \multicolumn{3}{|c|}{$\begin{array}{l}\text { Gravimetric water content } \\
\text { (grams per gram) }\end{array}$} & \multicolumn{3}{|c|}{$\begin{array}{l}\text { Water potential } \\
\text { (kilopascals) }\end{array}$} \\
\hline & & & Composite & Coarse & Fine & Composite & Coarse & Fine \\
\hline \multicolumn{9}{|c|}{ UE-25 } \\
\hline \multicolumn{9}{|c|}{ UZN \#22--Continued } \\
\hline & 8.4 & B & -- & 0.029 & -- & - & $-7,600$ & -- \\
\hline & 8.7 & B & - & .030 & -- & - & $-3,100$ & - \\
\hline & 9.0 & B & -- & .029 & -- & - & $-4,000$ & -- \\
\hline & 9.3 & B & -- & .033 & -- & -- & $-2,000$ & -- \\
\hline & 9.6 & B & - & .034 & - & - & $-2,600$ & - \\
\hline & 9.9 & B & -- & .037 & -- & -- & $-1,100$ & - \\
\hline & 10.2 & B & - & .037 & -- & - & -830 & - \\
\hline & 10.5 & $\mathrm{~B}$ & - & .039 & - & - & -790 & - \\
\hline & 10.8 & B & -- & .039 & -- & - & -780 & - \\
\hline & 11.4 & B & - & .023 & 0.012 & - & $-7,800$ & - \\
\hline & 12.0 & B & - & .024 & -- & -- & $-6,200$ & - \\
\hline & 12.3 & B & -- & .035 & - & - & -840 & - \\
\hline & 12.6 & B & -- & .040 & -- & - & -660 & - \\
\hline & 13.0 & B & -- & .043 & -- & - & -540 & - \\
\hline & 13.3 & B & -- & .043 & -- & -- & -560 & - \\
\hline & 13.6 & B & .- & .038 & -- & -- & -640 & - \\
\hline & 13.9 & B & -- & .038 & -- & -- & $-1,400$ & - \\
\hline & 14.2 & B & -- & .034 & -- & - & $-1,700$ & - \\
\hline & 14.5 & B & - & .032 & -- & - & $-3,500$ & - \\
\hline & 14.8 & B & -- & .025 & -- & - & $-6,100$ & - \\
\hline & 15.1 & B & - & .022 & -- & - & $-11,000$ & -- \\
\hline & 15.4 & B & -- & .024 & -- & -- & $-9,400$ & -- \\
\hline & 15.7 & B & -- & .019 & - & - & $-11,000$ & -- \\
\hline & 16.0 & B & -- & .020 & -- & - & $-11,000$ & - \\
\hline & 16.3 & B & -- & .019 & -- & - & $-12,000$ & -- \\
\hline & 16.6 & B & -- & .019 & - & -- & $-13,000$ & -- \\
\hline & 16.9 & B & -- & .018 & -- & -- & $-15,000$ & - \\
\hline & 17.2 & B & -- & .019 & -- & -- & $-14,000$ & - \\
\hline & 17.5 & B & - & .022 & -- & -- & $-7,500$ & - \\
\hline & 17.8 & B & -- & .024 & -- & - & $-4,100$ & - \\
\hline & 18.1 & B & -- & .022 & -- & - & $-5,100$ & - \\
\hline & 18.4 & B & -- & .031 & -- & - & $-3,300$ & - \\
\hline & 18.7 & B & -- & .033 & -. & - & $-1,400$ & -- \\
\hline & 19.0 & B & - & .028 & -- & - & $-4,100$ & -- \\
\hline & 19.4 & B & -- & .026 & -- & -- & $-5,600$ & - \\
\hline & 19.7 & B & - & .027 & - & -- & $-6,900$ & -- \\
\hline & 20.0 & B & -- & .025 & - & - & $-6,100$ & -- \\
\hline & 20.3 & B & -- & .023 & -- & -- & $-8,200$ & -- \\
\hline & 20.6 & B & -- & .023 & -- & - & $-8,500$ & - \\
\hline & 20.9 & B & -- & .022 & - & - & $-11,000$ & -- \\
\hline & 21.2 & B & -- & .021 & -. & - & $-16,000$ & - \\
\hline
\end{tabular}


Table 4. Results of laboratory analyses of hydrologic characteristics of drill cuttings from neutron-access boreholes--Continued

\begin{tabular}{|c|c|c|c|c|c|c|c|c|}
\hline \multirow{2}{*}{$\begin{array}{l}\text { Neutron- } \\
\text { access } \\
\text { borehole } \\
\text { number }\end{array}$} & \multirow{2}{*}{$\begin{array}{l}\text { Depth } \\
\text { (meters) }\end{array}$} & \multirow{2}{*}{ Rock type } & \multicolumn{3}{|c|}{$\begin{array}{l}\text { Gravimetric water content } \\
\text { (grams per gram) }\end{array}$} & \multicolumn{3}{|c|}{$\begin{array}{l}\text { Water potential } \\
\text { (kilopascals) }\end{array}$} \\
\hline & & & Composite & Coarse & Fine & Composite & Coarse & Firn \\
\hline \multicolumn{9}{|l|}{ UE-25 } \\
\hline \multicolumn{9}{|c|}{ UZN \#22--Continued } \\
\hline & 21.5 & B & -- & 0.028 & -- & -- & $-7,200$ & - \\
\hline & 21.8 & B & -- & .028 & -- & -- & $-7,000$ & - \\
\hline & 22.1 & B & -- & .031 & - & -- & $-7,000$ & -. \\
\hline & 22.4 & B & - & .032 & - & -- & $-6,100$ & - \\
\hline & 22.7 & B & - & .052 & - & -- & -630 & - \\
\hline & 23.0 & B & -- & .038 & - & -- & $-1,500$ & -. \\
\hline & 23.3 & B & -- & .035 & - & -- & $-1,800$ & - \\
\hline & 23.6 & B & -- & .033 & - & -- & $-3,700$ & - \\
\hline & 23.9 & B & -- & .032 & - & -- & $-3,500$ & -- \\
\hline & 24.2 & B & -- & .031 & - & -- & $-3,500$ & - \\
\hline & 24.5 & B & -- & .026 & - & -- & $-8,200$ & - \\
\hline & 24.8 & B & -- & .024 & - & -- & $-9,400$ & - \\
\hline & 25.1 & B & -- & .026 & - & -- & $-5,100$ & -- \\
\hline & 25.5 & B & -- & .027 & - & -- & $-5,300$ & - \\
\hline & 25.8 & B & -- & .028 & - & -- & $-4,300$ & - \\
\hline & 26.1 & B & -- & .025 & - & -- & $-6,900$ & - \\
\hline & 26.4 & B & -- & .026 & - & -- & $-7,100$ & - \\
\hline & 26.7 & B & -- & .024 & - & -- & $-7,700$ & - \\
\hline & 27.0 & B & -- & .022 & - & - & $-12,000$ & - \\
\hline & 27.3 & B & -- & .021 & - & -- & $-16,000$ & - \\
\hline & 27.6 & B & -- & .021 & - & -- & $-12,000$ & - \\
\hline & 27.9 & B & -. & .021 & - & -. & $-11,000$ & -- \\
\hline & 28.2 & B & -- & .020 & - & -- & $-11,000$ & - \\
\hline & 28.5 & B & -- & .020 & - & -. & $-10,000$ & - \\
\hline UE-25 & 3.2 & B & -- & .025 & - & -- & $-6,100$ & - \\
\hline \multirow[t]{9}{*}{$\mathrm{UZN} \# 23$} & 3.5 & B & -- & .024 & - & - & $-6,400$ & - \\
\hline & 4.0 & B & -- & .020 & - & -- & $-8,300$ & - \\
\hline & 4.6 & B & -- & .038 & - & -. & $-1,300$ & - \\
\hline & 5.0 & B & -- & .025 & - & -- & $-4,700$ & - \\
\hline & 5.3 & B & -- & .031 & - & -- & $-3,500$ & - \\
\hline & 5.6 & B & -- & .046 & - & -- & -640 & - \\
\hline & 5.9 & B & -- & .028 & - & -- & $-5,500$ & - \\
\hline & 6.2 & B & -- & .027 & -- & -- & $-5,700$ & - \\
\hline & 6.6 & B & -- & .029 & - & -- & $-5,000$ & - \\
\hline USW & 0.6 & B & -- & - & 0.025 & -- & $-14,000$ & - \\
\hline \multirow[t]{4}{*}{ UZ-N24 } & 1.4 & B & -- & - & .029 & -- & $-11,000$ & - \\
\hline & 1.7 & B & - & -- & .025 & -. & $-10,000$ & - \\
\hline & 2.0 & B & - & - & .024 & -- & $-9,900$ & -- \\
\hline & 2.3 & B & 0.021 & - & - & -- & $-15,000$ & -. \\
\hline
\end{tabular}


Table 4. Results of laboratory analyses of hydrologic characteristics of drill cuttings from neutron-access borehcles--Continued

\begin{tabular}{|c|c|c|c|c|c|c|c|c|}
\hline \multirow{2}{*}{$\begin{array}{c}\text { Neutron- } \\
\text { access } \\
\text { borehole } \\
\text { number }\end{array}$} & \multirow{2}{*}{$\begin{array}{l}\text { Depth } \\
\text { (meters) }\end{array}$} & \multirow{2}{*}{ Rock type } & \multicolumn{3}{|c|}{$\begin{array}{l}\text { Gravimetric water content } \\
\text { (grams per gram) }\end{array}$} & \multicolumn{3}{|c|}{$\begin{array}{l}\text { Water potential } \\
\text { (kilopascals) }\end{array}$} \\
\hline & & & Composite & Coarse & Fine & Composite & Coarse & Fine \\
\hline \multicolumn{9}{|c|}{ USW } \\
\hline \multicolumn{9}{|c|}{ UZ-N24--Continued } \\
\hline & 2.6 & B & -- & -- & 0.022 & - & $-8,900$ & - \\
\hline & 2.9 & B & -- & -- & .021 & - & $-8,100$ & - \\
\hline & 3.2 & B & - & - & .018 & - & $-8,500$ & -- \\
\hline & 3.5 & B & -- & 0.029 & -- & - & $-5,900$ & - \\
\hline & 3.8 & B & -- & - & .029 & - & $-8,500$ & - \\
\hline & 4.1 & B & -- & .041 & -- & - & $-2,800$ & - \\
\hline & 4.4 & B & -- & .046 & -- & - & $-1,700$ & - \\
\hline & 4.9 & B & - & -- & .042 & -. & $-1,900$ & - \\
\hline & 5.3 & B & - & .037 & -- & - & $-2,400$ & - \\
\hline & 5.6 & B & - & .034 & -- & -- & $-3,000$ & -- \\
\hline & 5.9 & B & -- & .078 & - & - & -680 & - \\
\hline & 6.2 & B & - & .071 & - & - & -890 & - \\
\hline & 6.6 & B & 0.057 & -- & -- & - & $-1,100$ & -- \\
\hline & 6.9 & B & -- & .084 & - & - & -840 & -- \\
\hline & 7.2 & B & - & .096 & - & -- & -720 & -- \\
\hline & 7.5 & B & -- & .098 & -- & -- & -650 & - \\
\hline & 7.9 & B & -- & .093 & - & - & -630 & - \\
\hline & 8.5 & B & - & .116 & - & -- & $-2,900$ & - \\
\hline & 9.0 & B & -- & .097 & -- & - & $-1,100$ & - \\
\hline & 9.3 & B & -- & .230 & -- & - & $-4,700$ & -- \\
\hline & 9.8 & B & - & .213 & -- & -- & -670 & - \\
\hline & 10.4 & B & - & .204 & -. & -- & -940 & - \\
\hline & 10.8 & B & -- & .156 & -- & -- & -950 & -. \\
\hline & 11.3 & B & -- & .144 & -- & -- & -890 &.- \\
\hline & 11.9 & B & -- & .156 & -- & - & $-1,000$ & - \\
\hline & 12.5 & B & -- & .165 & - & - & -650 & - \\
\hline & 13.0 & B & -- & .179 & -- & - & -570 & - \\
\hline & 13.3 & B & - & .182 & - & -- & -490 & - \\
\hline & 13.6 & B & - & .191 & -- & - & -570 & - \\
\hline & 13.9 & B & - & .199 & -- & - & -520 & - \\
\hline & 14.2 & B & - & .217 & -- & - & -500 & - \\
\hline & 14.5 & B & -- & .291 & -- & - & -490 & -- \\
\hline & 14.8 & B & - & .297 & -- & -- & -530 & -. \\
\hline & 15.1 & B & -- & .235 & - & -- & -470 & -. \\
\hline & 15.4 & B & -- & .181 & -- & - & -490 & -- \\
\hline & 15.7 & B & -- & .528 & - & - & -350 & - \\
\hline & 16.0 & B & -- & .283 & - & -- & -280 & -- \\
\hline & 16.3 & B & -- & .421 & - & - & -350 & - \\
\hline & 16.6 & B & - & -- & -- & -- & -- & - \\
\hline & 17.1 & B & - & .293 & -- & - & -760 & - \\
\hline & 17.7 & B & -- & -- & .209 & - & -710 & - \\
\hline
\end{tabular}


Table 4. Results of laboratory analyses of hydrologic characteristics of drill cuttings from neutron-access boreholes--Continued

\begin{tabular}{|c|c|c|c|c|c|c|c|c|}
\hline \multirow{2}{*}{$\begin{array}{c}\text { Neutron- } \\
\text { access } \\
\text { borehole } \\
\text { number }\end{array}$} & \multirow{2}{*}{$\begin{array}{l}\text { Depth } \\
\text { (meters) }\end{array}$} & \multirow{2}{*}{ Rock type } & \multicolumn{3}{|c|}{$\begin{array}{l}\text { Gravimetrlc water content } \\
\text { (grams per gram) }\end{array}$} & \multicolumn{3}{|c|}{$\begin{array}{l}\text { Water potentlal } \\
\text { (kllopascals) }\end{array}$} \\
\hline & & & Composite & Coarse & Fine & Composite & Coarse & FI-O \\
\hline \multicolumn{9}{|c|}{ USW } \\
\hline \multicolumn{9}{|c|}{ UZ-N24--Continued } \\
\hline & 18.1 & B & - & - & 0.201 & - & -830 & -. \\
\hline & 18.7 & B & -. & - & .191 & -. & -850 & -. \\
\hline & 19.5 & B & - & -- & .168 & - & -440 & - \\
\hline & 20.1 & B & -. & -. & .150 & -- & -520 & -- \\
\hline & 20.7 & B & -- & - & .210 & -. & -440 & - \\
\hline & 21.2 & B & -- & -- & .306 & -. & -470 & - \\
\hline & 21.6 & B & -- & 0.166 & -. & - & -470 & $\cdots$ \\
\hline & 22.3 & B & -- & - & .167 & - & -530 & - \\
\hline & 22.7 & B & -- & - & .183 & - & -550 & -- \\
\hline USW & 0.3 & B & -- & .051 & -- & - & $-1,500$ & -- \\
\hline \multirow{30}{*}{ UZ-N25 } & .8 & B & -- & .042 & - & - & $-2,700$ & -. \\
\hline & 1.1 & B & -- & .032 & -- & -- & $-5,000$ & -. \\
\hline & 1.4 & B & -- & .033 & -. & - & $-3,800$ & -. \\
\hline & 1.8 & B & - & .032 & -- & - & $-3,500$ & - \\
\hline & 2.3 & B & - & .042 & - & - & $-1,400$ & - \\
\hline & 2.6 & B & - & .045 & -- & -. & -950 & -. \\
\hline & 2.9 & B & - & .047 & -. & -. & -830 & - \\
\hline & 3.2 & B & - & - & - & -. & - & - \\
\hline & 3.5 & B & - & .046 & - & - & $-1,100$ & - \\
\hline & 3.8 & B & -- & .047 & - & - & $-1,000$ & -- \\
\hline & 4.1 & B & - & .053 & -- & -. & -940 & -. \\
\hline & 4.4 & B & -- & .037 & - & - & -790 & -- \\
\hline & 4.7 & B & -- & -- & -- & - & - & -- \\
\hline & 5.2 & B & -- & .031 & -- & - & -990 & - \\
\hline & 5.6 & B & - & .026 & - & -. & $-3,300$ & -. \\
\hline & 5.9 & B & -- & .029 & - & - & $-3,800$ & - \\
\hline & 6.2 & B & -. & .029 & - & - & $-3,200$ & -- \\
\hline & 6.6 & B & -- & .035 & -- & -- & $-1,500$ & -- \\
\hline & 6.9 & B & -- & .035 & -- & -- & $-1,600$ & - \\
\hline & 7.2 & B & -- & .036 & -- & - & $-1,100$ & - \\
\hline & 7.5 & B & -- & .035 & -- & - & $-1,300$ & -. \\
\hline & 7.8 & B & -- & .034 & -- & -- & $-1,700$ & - \\
\hline & 8.1 & B & -- & .031 & -- & - & $-3,200$ & -. \\
\hline & 8.4 & B & -- & .043 & -- & - & $-1,200$ & - \\
\hline & 8.7 & B & - & .035 & -- & - & $-2,000$ & - \\
\hline & 9.0 & B & - & .045 & -- & - & -900 & -. \\
\hline & 9.3 & B & -- & .041 & - & - & $-3,500$ & -- \\
\hline & 9.6 & B & - & .065 & -- & -. & -620 & -- \\
\hline & 9.9 & B & -- & .060 & -- & - & -630 & - \\
\hline & 10.2 & B & -- & .060 & - & - & -600 & - \\
\hline
\end{tabular}


Table 4. Results of laboratory analyses of hydrologic characteristics of drill cuttings from neutron-access boreho'es--Continued

\begin{tabular}{|c|c|c|c|c|c|c|c|c|}
\hline \multirow{2}{*}{$\begin{array}{c}\text { Neutron- } \\
\text { access } \\
\text { borehole } \\
\text { number }\end{array}$} & \multirow{2}{*}{$\begin{array}{c}\text { Depth } \\
\text { (meters) }\end{array}$} & \multirow{2}{*}{ Rock type } & \multicolumn{3}{|c|}{$\begin{array}{l}\text { Gravimetric water content } \\
\text { (grams per gram) }\end{array}$} & \multicolumn{3}{|c|}{$\begin{array}{l}\text { Water potential } \\
\text { (kliopascais) }\end{array}$} \\
\hline & & & Composite & Coarse & Fine & Composite & Coarse & Fine \\
\hline \multicolumn{9}{|l|}{ USW } \\
\hline \multicolumn{9}{|c|}{ UZ-N25-Continued } \\
\hline & 10.5 & B & -. & 0.070 & - & -- & -620 & - \\
\hline & 10.8 & B & - & .075 & -- & -- & -610 & - \\
\hline & 11.1 & B & - & .073 & - & - & -640 & - \\
\hline & 11.4 & B & -- & .069 & -- & - & -440 & - \\
\hline & 11.7 & B & -- & .078 & - & -- & -400 & - \\
\hline & 12.0 & B & - & .078 & - & - & -530 & - \\
\hline & 12.5 & B & - & .064 & - & - & -570 & -. \\
\hline & 13.1 & $\mathrm{~B}$ & - & .063 & - & - & -600 & - \\
\hline & 13.7 & B & -- & .062 & - & - & -410 & - \\
\hline & 14.3 & B & -- & .064 & -- & - & -600 & -- \\
\hline & 14.9 & B & -- & .067 & -- & - & -580 & - \\
\hline & 15.5 & B & -- & .071 & -- & -- & -650 & - \\
\hline & 16.2 & B & - & .069 & - & -- & -640 & -- \\
\hline & 16.8 & B & -- & .074 & -- & -- & -630 & -- \\
\hline & 17.4 & B & - & .078 & -- & - & -680 & - \\
\hline & 17.8 & B & -- & .082 & - & - & - & -- \\
\hline USW & 0.3 & B & - & .051 & - & - & -540 & - \\
\hline \multirow[t]{23}{*}{ UZ-N26 } & .8 & B & -- & .044 & - & - & -350 & -- \\
\hline & 1.1 & B & -- & .032 & -- & - & $-2,200$ & -- \\
\hline & 1.4 & B & - & .024 & - & - & $-3,900$ & -- \\
\hline & 1.8 & B & -- & .015 & -- & - & $-9,000$ & - \\
\hline & 2.3 & B & -- & .018 & -- & -- & $-8,100$ & - \\
\hline & 2.6 & B & - & .020 & -- & -- & $-7,100$ & - \\
\hline & 2.9 & B & -- & .024 & -- & - & $-3,600$ & - \\
\hline & 3.4 & B & -- & .023 & -. & - & $-5,800$ & - \\
\hline & 3.8 & B & - & .022 & -- & -. & $-6,600$ & - \\
\hline & 4.1 & B & -- & .016 & - & - & $-10,000$ & -- \\
\hline & 4.4 & B & -- & .016 & - & - & $-13,000$ & - \\
\hline & 4.7 & B & - & .012 & -- & -- & $-24,000$ & - \\
\hline & 5.0 & B & -. & .010 & -. & - & $-26,000$ & -- \\
\hline & 5.3 & B & -- & .021 & -- & -- & $-9,100$ & -- \\
\hline & 5.6 & B & -- & .029 & -- & -- & $-3,700$ & - \\
\hline & 5.9 & B & -- & .032 & - & -- & $-1,600$ & - \\
\hline & 6.4 & B & -- & .026 & - & - & $-2,700$ & -- \\
\hline & 6.9 & B & -- & .026 & - & -- & $-3,900$ & - \\
\hline & 7.2 & B & -- & .030 & - & - & $-3,400$ & -. \\
\hline & 7.5 & B & -- & .026 & -- & -- & $-3,600$ & -- \\
\hline & 7.8 & B & -- & .027 & -- & -- & $-2,800$ & - \\
\hline & 8.1 & B & - & .020 & - & -- & $-7,400$ & -- \\
\hline & 8.4 & B & -. & .026 & - & - & $-3,200$ & -. \\
\hline
\end{tabular}


Table 4. Results of laboratory analyses of hydrologic characteristics of drill cuttings from neutron-access boreholes--Continued

\begin{tabular}{|c|c|c|c|c|c|c|c|c|}
\hline \multirow{2}{*}{$\begin{array}{c}\text { Neutron- } \\
\text { access } \\
\text { borehole } \\
\text { number }\end{array}$} & \multirow{2}{*}{$\begin{array}{c}\text { Depth } \\
\text { (meters) }\end{array}$} & \multirow{2}{*}{ Rock type } & \multicolumn{3}{|c|}{$\begin{array}{l}\text { Gravimetrlc water content } \\
\text { (grams per gram) }\end{array}$} & \multicolumn{3}{|c|}{$\begin{array}{l}\text { Water potential } \\
\text { (kilopascals) }\end{array}$} \\
\hline & & & Composite & Coarse & Fine & Composite & Coarse & Fine \\
\hline \multicolumn{9}{|c|}{ USW } \\
\hline \multicolumn{9}{|c|}{ UZ-N26--Continued } \\
\hline & 8.7 & B & $\cdots$ & 0.024 & - & -- & $-4,700$ & $\cdots$ \\
\hline & 9.0 & B & - & .025 & -- & -- & $-6,000$ & - \\
\hline & 9.3 & B & -- & .018 & - & -- & $-11,000$ & - \\
\hline & 9.6 & B & - & .021 & - & -- & $-10,000$ & - \\
\hline & 9.9 & B & -- & .036 & - & -- & $-3,900$ & -- \\
\hline & 10.2 & B & -- & .021 & -- & -- & $-11,000$ & -- \\
\hline & 10.5 & B & $\cdots$ & .016 & - & -- & $-16,000$ & - \\
\hline UE-25 & 0.3 & A & -- & .043 & -- & -- & -960 & -- \\
\hline \multirow[t]{19}{*}{$\mathrm{UZN} \# 28$} & .8 & A & - & .051 & - & -- & -680 & -- \\
\hline & 1.1 & A & - & .051 & -- & -- & -670 & -- \\
\hline & 1.4 & A & -- & .049 & - & - & -710 & -- \\
\hline & 1.7 & A & -- & .045 & - & -- & -830 & -- \\
\hline & 2.1 & A & -- & .039 & - & -- & $-1,600$ & -- \\
\hline & 2.6 & A & -- & .031 & - & -- & $-4,300$ & -- \\
\hline & 2.9 & A & -- & .033 & - & -- & $-3,100$ & -- \\
\hline & 3.2 & A & -- & .028 & - & -- & $-4,700$ & - \\
\hline & 3.7 & A & - & .029 & - & -- & $-4,800$ & - \\
\hline & 4.1 & A & -- & .034 & - & -- & $-3,600$ & $\cdots$ \\
\hline & 4.4 & A & $\cdots$ & .033 & - & -- & $-3,700$ & $\cdots$ \\
\hline & 4.7 & A & -- & .030 & -. & -- & $-3,800$ &.- \\
\hline & 5.2 & A & -- & .034 & - & -- & $-2,500$ & - \\
\hline & 5.6 & A & -- & .038 & -- & -- & $-1,300$ & $\cdots$ \\
\hline & 5.9 & A & -- & .036 & -- & - & $-2,400$ & -- \\
\hline & 6.2 & A & -- & -- & -- & - & -- & - \\
\hline & 6.7 & A & -- & .035 & - & -- & $-2,200$ & -- \\
\hline & 7.2 & A & -- & .039 & - & -- & $-1,400$ & -- \\
\hline & 7.5 & A & $-\cdot$ & .039 & -- & - & $-1,500$ & $\cdots$ \\
\hline UE-25 & .3 & A & - & .040 & -- & -- & $-2,300$ & -- \\
\hline \multirow[t]{11}{*}{ UZN \#29 } & .8 & B & -- & .033 & - & -- & $-2,100$ & - \\
\hline & 1.1 & B & -- & .038 & -- & -- & $-1,000$ & -- \\
\hline & 1.4 & B & -- & .038 & -- & - & $-1,700$ & - \\
\hline & 1.8 & B & -- & .034 & -- & -- & $-3,800$ & - \\
\hline & 2.3 & B & -- & .035 & -- & -- & $-4,000$ & -- \\
\hline & 2.6 & B & -- & .033 & -- & -- & $-3,800$ & - \\
\hline & 2.9 & B & - & .037 & -- & - & $-2,200$ & -- \\
\hline & 3.2 & B & -- & .030 & -- & -- & $-7,600$ & - \\
\hline & 3.7 & B & -- & .033 & - & -- & $-4,800$ & -- \\
\hline & 4.1 & B & - & .035 & - & -- & $-3,100$ & -- \\
\hline & 4.4 & B & -. & .038 & - & -- & $-1,200$ & -- \\
\hline
\end{tabular}


Table 4. Results of laboratory analyses of hydrologic characteristics of drill cuttings from neutron-access boreholes--Continued

\begin{tabular}{|c|c|c|c|c|c|c|c|c|}
\hline \multirow{2}{*}{$\begin{array}{c}\text { Neutron- } \\
\text { access } \\
\text { borehole } \\
\text { number }\end{array}$} & \multirow{2}{*}{$\begin{array}{l}\text { Depth } \\
\text { (meters) }\end{array}$} & \multirow{2}{*}{ Rock type } & \multicolumn{3}{|c|}{$\begin{array}{l}\text { Gravimetric water content } \\
\text { (grams per gram) }\end{array}$} & \multicolumn{3}{|c|}{$\begin{array}{l}\text { Water potential } \\
\text { (kilopascals) }\end{array}$} \\
\hline & & & Composite & Coarse & Fine & Composite & Coarse & Fine \\
\hline \multicolumn{9}{|c|}{ UE-25 } \\
\hline \multicolumn{9}{|c|}{ UZN \#29--Continued } \\
\hline & 4.7 & B & -- & 0.038 & - & - & $-1,300$ & - \\
\hline & 5.2 & B & -- & .037 & - & - & $-2,800$ & - \\
\hline & 5.6 & B & - & .044 & - & - & -890 & - \\
\hline & 5.9 & B & - & .045 & - & - & -680 & - \\
\hline & 6.2 & B & -- & .051 & -- & - & -620 & - \\
\hline & 6.6 & B & - & .035 & -- & - & $-3,200$ & - \\
\hline & 7.0 & B & -- & .042 & - & - & -770 & - \\
\hline & 7.5 & B & - & .043 & - & - & -780 & - \\
\hline & 7.8 & B & - & .042 & -- & - & -730 & - \\
\hline & 8.2 & B & -- & .038 & - & - & $-1,000$ & - \\
\hline & 8.7 & B & -- & .027 & - & -- & $-4,500$ & - \\
\hline & 9.0 & B & -- & .032 & -- & - & $-3,300$ & - \\
\hline & 9.3 & B & -- & .033 & -- & -- & $-4,000$ & - \\
\hline & 9.6 & B & -- & .039 & -- & -- & $-1,300$ & - \\
\hline & 10.1 & B & - & .033 & -- & - & $-5,000$ & - \\
\hline & 10.5 & B & -- & .037 & -- & - & $-3,200$ & - \\
\hline UE-25 & 0.3 & A & - & -- & -- & - & $-6,800$ & -- \\
\hline \multirow[t]{23}{*}{ UZN \#30 } & .8 & B & - & .040 & -- & - & $-1,500$ & - \\
\hline & 1.1 & B & -- & .039 & - & - & $-1,900$ & -- \\
\hline & 1.4 & B & -- & .040 & -- & - & $-2,500$ & -- \\
\hline & 1.8 & B & -- & .039 & - & - & $-1,200$ & - \\
\hline & 2.3 & B & -- & .037 & -- & - & $-1,500$ & - \\
\hline & 2.6 & B & -- & .039 & -- & - & $-2,100$ & - \\
\hline & 2.9 & B &.- & .043 & -- & - & $-1,400$ & - \\
\hline & 3.2 & B & - & - & -- & -- & - & - \\
\hline & 3.5 & B & -- & .035 & -- & - & $-2,800$ & -- \\
\hline & 3.8 & B & - & .042 & -- & - & $-1,200$ & - \\
\hline & 4.1 & B & -- & .050 & -- & - & -680 & - \\
\hline & 4.4 & B & - & .050 & -- & -- & -480 & - \\
\hline & 4.7 & B & -- & .048 & -- & - & -540 & -- \\
\hline & 5.0 & B & -- & .049 & - & - & -620 & - \\
\hline & 5.3 & B & -. & .045 & -- & - & -550 & -- \\
\hline & 5.6 & B & -- & .042 & -- & -- & -950 & - \\
\hline & 5.9 & B & -- & .048 & -. & -- & -730 & - \\
\hline & 6.2 & B & - & .051 & -. & - & -820 & -- \\
\hline & 6.6 & B & -. & .048 & -- & -- & -820 & -- \\
\hline & 6.9 & B & -- & .045 & -- & -- & $-1,100$ & - \\
\hline & 7.2 & B & -- & .043 & -. & -- & $-1,100$ & -- \\
\hline & 7.5 & B & -- & .038 & -- & -- & $-1,800$ & -- \\
\hline & 7.8 & B & - & .042 & -- & -- & $-1,400$ & -- \\
\hline
\end{tabular}


Table 4. Results of laboratory analyses of hydrologic characteristics of drill cuttings from neutron-access boreholes--Ccntinued

\begin{tabular}{|c|c|c|c|c|c|c|c|c|}
\hline \multirow{2}{*}{$\begin{array}{c}\text { Neutron- } \\
\text { access } \\
\text { borehole } \\
\text { number }\end{array}$} & \multirow{2}{*}{$\begin{array}{c}\text { Depth } \\
\text { (meters) }\end{array}$} & \multirow{2}{*}{ Rock type } & \multicolumn{3}{|c|}{$\begin{array}{l}\text { Gravimetric water content } \\
\text { (grams per gram) }\end{array}$} & \multicolumn{3}{|c|}{$\begin{array}{l}\text { Water potential } \\
\text { (kliopascals) }\end{array}$} \\
\hline & & & Composite & Coarse & Fine & Composite & Coarse & Fing \\
\hline \multicolumn{9}{|l|}{ UE-25 } \\
\hline \multicolumn{9}{|c|}{ UZN \#30--Continued } \\
\hline & 8.1 & B & -- & 0.044 & - & -- & -670 & - \\
\hline & 8.4 & B & - & .046 & -- & -- & -640 & - \\
\hline & 8.7 & B & - & .037 & -- & -- & -730 & - \\
\hline & 9.0 & B & -- & .039 & - & -- & -820 & - \\
\hline & 9.3 & B & -- & .039 & - & -- & $-1,300$ & - \\
\hline & 9.6 & B & -- & .035 & -- & -- & $-2,400$ & - \\
\hline & 9.9 & B & -- & .036 & -- & -- & $-1,100$ & - \\
\hline & 10.2 & B & - & .037 & -- & -- & $-1,600$ & - \\
\hline & 10.5 & B & -- & .037 & - & - & -950 & -- \\
\hline USW & 0.6 & A & - & .030 & 0.047 & -- & $-6,000$ & - \\
\hline \multirow[t]{27}{*}{ UZ-N40 } & 1.1 & B & -- & .038 & - & -- & $-1,200$ & -- \\
\hline & 1.4 & B & -- & .031 & -- & -- & $-2,300$ & - \\
\hline & 1.7 & B & -- & .031 & -- & -- & $-1,900$ & -. \\
\hline & 2.1 & B & -- & .023 & -- & -- & $-3,500$ & - \\
\hline & 2.6 & B & -- & .038 & -- & -- & -940 & -- \\
\hline & 2.9 & B & -- & .046 & -- & -- & -760 & -- \\
\hline & 3.2 & B & -- & .043 & - & -- & -900 & - \\
\hline & 3.7 & B & -- & .036 & -- & - & $-1,100$ & $\cdots$ \\
\hline & 4.1 & B & - & .036 & -- & - & -440 & - \\
\hline & 4.4 & B & - & .048 & .043 & -- & -540 & -- \\
\hline & 4.7 & B & -- & .044 & - & -- & -700 & - \\
\hline & 5.2 & B & - & .033 & - & - & -720 & - \\
\hline & 5.6 & B & - & .026 & -- & -- & $-2,300$ & -. \\
\hline & 5.9 & B & -- & .024 & -- & - & $-3,100$ & - \\
\hline & 6.2 & B & -- & .024 & - & -- & $-4,000$ & - \\
\hline & 6.7 & B & -- & .019 & -- & -- & $-4,800$ & - \\
\hline & 7.2 & B & -- & .022 & - & - & $-5,300$ & - \\
\hline & 7.5 & B & - & .029 & - & - & $-3,100$ & -- \\
\hline & 7.8 & B & -- & .030 & -- & - & $-2,500$ & -. \\
\hline & 8.1 & B & - & .027 & - & -- & $-3,800$ & -- \\
\hline & 8.4 & B & -- & .023 & - & - & $-5,800$ & -- \\
\hline & 8.7 & B & -- & .021 & -. & - & $-6,600$ & -- \\
\hline & 9.0 & B & - & .021 & - & - & $-7,300$ & - \\
\hline & 9.3 & B & -- & .020 & -- & - & $-7,600$ & - \\
\hline & 9.8 & B & -- & .016 & - & -- & $-9,000$ & -- \\
\hline & 10.2 & B & - & .017 & - & -- & $-9,300$ & -- \\
\hline & 10.5 & B & -- & .017 & - & -- & $-7,300$ & - \\
\hline
\end{tabular}


Table 4. Results of laboratory analyses of hydrologic characteristics of drill cuttings from neutron-access borehcles--Continued

\begin{tabular}{|c|c|c|c|c|c|c|c|c|}
\hline \multirow{2}{*}{$\begin{array}{c}\text { Neutron- } \\
\text { access } \\
\text { borehole } \\
\text { number }\end{array}$} & \multirow{2}{*}{$\begin{array}{l}\text { Depth } \\
\text { (meters) }\end{array}$} & \multirow{2}{*}{ Rock type } & \multicolumn{3}{|c|}{$\begin{array}{l}\text { Gravimetric water content } \\
\text { (grams per gram) }\end{array}$} & \multicolumn{3}{|c|}{$\begin{array}{l}\text { Water potential } \\
\text { (kliopascals) }\end{array}$} \\
\hline & & & Composite & Coarse & Fine & Composite & Coarse & Fine \\
\hline USW & 0.3 & $\mathbf{A}$ & -- & 0.069 & $\overline{-}$ & - & -980 & - \\
\hline \multirow[t]{25}{*}{ UZ-N41 } & .8 & A & -- & .042 & -- & - & $-1,400$ & - \\
\hline & 1.1 & A & -- & .037 & -- & - & $-2,100$ & - \\
\hline & 1.4 & A & -- & .025 & -- & - & $-3,400$ & -- \\
\hline & 1.7 & A & - & .022 & - & - & $-8,000$ & -- \\
\hline & 2.1 & $A$ & -- & .032 & - & - & $-2,800$ & - \\
\hline & 2.6 & A & -- & .037 & - & - & $-2,600$ & - \\
\hline & 2.9 & A & -- & .040 & -. & - & $-1,300$ & - \\
\hline & 3.2 & A & -- & .050 & -- & - & -840 & - \\
\hline & 3.7 & A & -- & .052 & -- & - & -760 & - \\
\hline & 4.1 & A & -- & .038 & - & - & $-2,300$ & -- \\
\hline & 4.4 & A & -- & .038 & -- & -- & $-2,700$ & - \\
\hline & 4.7 & A & -- & .038 & -- & -- & $-2,300$ & - \\
\hline & 5.2 & B & -- & .032 & -- & - & $-1,100$ & - \\
\hline & 5.6 & B & -- & .022 & -- & - & $-4,500$ & - \\
\hline & 5.9 & B & -- & .027 & -- & - & $-3,300$ & - \\
\hline & 6.2 & B & -- & .029 & -- & -- & $-3,600$ & - \\
\hline & 6.7 & B & -- & .021 & -- & - & $-8,400$ & - \\
\hline & 7.2 & B & - & .022 & -- & - & $-5,700$ & - \\
\hline & 7.5 & B & - & .028 & - & - & $-3,900$ & - \\
\hline & 7.8 & B & -- & .026 & -- & - & $-4,200$ & - \\
\hline & 8.1 & B & -- & .025 & -- & - & $-4,100$ & -- \\
\hline & 8.4 & B & -- & .023 & -- & - & $-6,300$ & - \\
\hline & 8.7 & B & -- & .022 & -- & - & $-4,800$ & - \\
\hline & 9.0 & B & -- & .019 & -- & -- & $-8,200$ & -- \\
\hline & 9.3 & B & -- & .021 & -. & -- & $-4,200$ & - \\
\hline & 9.6 & B & - & .018 & - & - & $-4,600$ & - \\
\hline & 9.9 & B & -- & .021 & -- & -- & $-4,300$ & - \\
\hline & 10.2 & B & - & .019 & -- & - & $-4,200$ & -- \\
\hline & 10.5 & B & -- & .015 & -- & - & $-8,900$ & - \\
\hline USW & .5 & B & -- & -- & -- & - & $-36,000$ & - \\
\hline \multirow[t]{11}{*}{ UZ-N42 } & 1.1 & B & -- & .019 & -- & -- & - & - \\
\hline & 1.2 & B & -- & -- & - & - & $-14,000$ & -- \\
\hline & 1.4 & B & -- & - & - & - & - & -- \\
\hline & 1.7 & B & -- & .020 & - & - & $-13,000$ & - \\
\hline & 2.0 & B & -- & - & -- & -- & $-15,000$ & - \\
\hline & 2.3 & B & -- & .028 & -- & -. & $-6,600$ & - \\
\hline & 2.6 & B & -- & .027 & -- & - & $-6,600$ & - \\
\hline & 2.9 & B & -- & .025 & -- & - & $-8,500$ & -- \\
\hline & 3.2 & B & -- & .028 & -- & -- & $-7,400$ & -- \\
\hline & 4.1 & B & - & .026 & -- & -- & $-10,000$ & - \\
\hline & 5.0 & B & -. & .024 & -- & -- & $-7,500$ & -- \\
\hline
\end{tabular}


Table 4. Results of laboratory analyses of hydrologic characteristics of drill cuttings from neutron-access boreholes--Continued

\begin{tabular}{|c|c|c|c|c|c|c|c|c|}
\hline \multirow{2}{*}{$\begin{array}{c}\text { Neutron- } \\
\text { access } \\
\text { borehole } \\
\text { number }\end{array}$} & \multirow{2}{*}{$\begin{array}{l}\text { Depth } \\
\text { (meters) }\end{array}$} & \multirow{2}{*}{ Rock type } & \multicolumn{3}{|c|}{$\begin{array}{l}\text { Gravimetric water content } \\
\text { (grams per gram) }\end{array}$} & \multicolumn{3}{|c|}{$\begin{array}{l}\text { Water potential } \\
\text { (kilopascals) }\end{array}$} \\
\hline & & & Composite & Coarse & Fine & Composite & Coarse & Fine \\
\hline \multicolumn{9}{|l|}{ USW } \\
\hline \multicolumn{9}{|c|}{ UZ-N42--Continued } \\
\hline & 5.3 & B & -- & 0.026 & - & - & $-7,100$ & -- \\
\hline & 5.6 & B & -- & .028 & -- & -- & $-7,500$ & -- \\
\hline & 5.9 & B & - & .030 & -- & -- & $-2,400$ & -- \\
\hline & 6.2 & B & - & .030 & - & -- & $-4,300$ & - \\
\hline & 6.9 & B & -- & .017 & - & -- & $-9,700$ & - \\
\hline & 7.5 & B & -- & .015 & - & - & $-13,000$ & - \\
\hline & 7.8 & B & -- & .023 & -- & - & $-7,100$ & -. \\
\hline & 8.1 & B & -- & .026 & -- & -- & $-5,200$ & - \\
\hline & 8.4 & B & - & .028 & - & - & $-4,900$ & -- \\
\hline & 8.7 & B & -- & .030 & -- & - & $-3,700$ & - \\
\hline & 9.0 & B & -- & .034 & - & - & $-2,700$ &.- \\
\hline & 9.3 & B & -- & .025 & -- & -- & $-5,400$ & - \\
\hline & 9.6 & B & -- & .030 & - & -- & $-5,600$ & -- \\
\hline & 9.9 & B & - & .024 & - & -- & $-7,200$ & - \\
\hline & 10.2 & B & -- & .019 & -- & -- & $-8,800$ & - \\
\hline & 10.5 & B & -- & .026 & - & -- & $-6,200$ & -- \\
\hline USW & 0.3 & A & -- & -- & 0.045 & -- & -- & $-7,2.00$ \\
\hline \multirow[t]{23}{*}{ UZ-N43 } & .9 & A & -- & - & -- & -- & -- & $-20, C, 0$ \\
\hline & 1.5 & A & -- & .028 & -- & -- & $-3,100$ & -- \\
\hline & 2.1 & A & -- & .033 & - & -- & $-5,100$ & -- \\
\hline & 2.7 & A & - & .029 & -- & -- & $-3,700$ & -- \\
\hline & 3.2 & A & -- & .024 & -- & -- & $-7,200$ & -- \\
\hline & 3.7 & A & -- & .021 & - & -- & $-9,000$ & -- \\
\hline & 4.3 & A & -- & .025 & - & -- & $-9,600$ & -- \\
\hline & 4.7 & A & - & .033 & - & -- & $-7,100$ & - \\
\hline & 5.2 & A & - & .023 & -- & - & $-11,000$ & -- \\
\hline & 5.8 & A & - & .025 & - & -- & $-2,900$ & - \\
\hline & 6.2 & A & -- & .025 & - & -- & $-3,200$ & - \\
\hline & 6.7 & A & -- & .026 & -- & - & $-2,800$ & - \\
\hline & 7.2 & A & -- & .025 & -- & -- & $-4,300$ & - \\
\hline & 7.5 & A & -- & .024 & -- & -- & $-5,600$ & -- \\
\hline & 7.8 & A & -- & .025 & -- & - & $-4,800$ & - \\
\hline & 8.1 & A & -- & .027 & -- & -- & $-3,600$ & - \\
\hline & 8.4 & B & -- & .023 & - & -- & $-6,500$ & -- \\
\hline & 8.7 & B & -- & .019 & - & -- & $-11,000$ & -- \\
\hline & 9.0 & B & -- & .024 & - & -- & $-9,100$ & - \\
\hline & 9.3 & B & - & .018 & -- & -- & $-11,000$ & -- \\
\hline & 9.8 & B & -- & .019 & - & -- & $-11,000$ & -- \\
\hline & 10.2 & B & -- & .019 & - & - & $-15,000$ & - \\
\hline & 10.5 & B & -- & .021 & -- & -- & $-14,000$ & - \\
\hline
\end{tabular}


Table 4. Results of laboratory analyses of hydrologic characteristics of drill cuttings from neutron-access boreholes--Continued

\begin{tabular}{|c|c|c|c|c|c|c|c|c|}
\hline \multirow{2}{*}{$\begin{array}{l}\text { Neutron- } \\
\text { access } \\
\text { borehole } \\
\text { number }\end{array}$} & \multirow{2}{*}{$\begin{array}{l}\text { Depth } \\
\text { (meters) }\end{array}$} & \multirow{2}{*}{ Rock type } & \multicolumn{3}{|c|}{$\begin{array}{l}\text { Gravimetric water content } \\
\text { (grams per gram) }\end{array}$} & \multicolumn{3}{|c|}{$\begin{array}{l}\text { Water potential } \\
\text { (kllopascals) }\end{array}$} \\
\hline & & & Composite & Coarse & Fine & Composite & Coarse & Fine \\
\hline \multicolumn{9}{|l|}{ USW } \\
\hline \multicolumn{9}{|c|}{ UZ-N43--Continued } \\
\hline & 11.0 & B & -- & 0.017 & -- & -- & $-15,000$ & - \\
\hline & 11.6 & B & -- & .019 & -- & -- & $-14,000$ & - \\
\hline & 12.0 & B & -- & .022 & - & -- & $-8,100$ & - \\
\hline & 12.3 & B & -- & .026 & -- & -- & $-6,200$ & - \\
\hline & 12.6 & B & - & .027 & -- & -- & $-4,000$ & - \\
\hline & 13.0 & B & - & .025 & -- & -- & $-7,400$ & - \\
\hline & 13.3 & B & - & .026 & - & - & $-5,600$ & - \\
\hline & 13.6 & B & - & .026 & - & - & $-6,400$ & - \\
\hline USW & 0.3 & B & -- & .049 & - & - & -630 & - \\
\hline \multirow[t]{27}{*}{ UZ-N44 } & .8 & B & -- & .029 & -- & -- & $-1,300$ & - \\
\hline & $1: 1$ & B & - & -- & -- & - & $-6,600$ & - \\
\hline & 1.4 & B & -- & .022 & -. & - & $-5,100$ & - \\
\hline & 2.3 & B & -- & .019 & -. & - & $-5,600$ & - \\
\hline & 3.2 & B & -- & .024 & -- & - & $-2,500$ & - \\
\hline & 3.5 & B & -- & .026 & -- & - & $-2,800$ & - \\
\hline & 3.8 & B & -- & .018 & -- & - & $-4,200$ & - \\
\hline & 4.1 & B & -- & .009 & -- & - & $-14,000$ & - \\
\hline & 4.4 & B & -. & .018 & - & - & $-6,900$ & - \\
\hline & 5.0 & B & -- & .014 & -. & -. & $-7,900$ & - \\
\hline & 5.6 & B & -- & .020 & -- & - & $-6,800$ & - \\
\hline & 5.9 & B & - & .019 & - & - & $-8,000$ & - \\
\hline & 6.2 & B & -. & .020 & -- & - & $-7,500$ & - \\
\hline & 6.6 & B & -- & .019 & -. & - & $-11,000$ & - \\
\hline & 6.9 & B & - & .019 & -- & - & $-9,500$ & - \\
\hline & 7.2 & B & - & .016 & -- & - & $-13,000$ & -- \\
\hline & 7.5 & B & -- & .015 & - & - & $-11,000$ & - \\
\hline & 7.8 & B & -- & .016 & - & - & $-9,500$ & -. \\
\hline & 8.1 & B & -- & -- & - & - & - & - \\
\hline & 8.4 & B & -- & .018 & -- & - & $-10,000$ & - \\
\hline & 8.7 & B & - & .025 & -- & - & $-6,500$ & - \\
\hline & 9.0 & B & - & .027 & -- & - & $-5,100$ & - \\
\hline & 9.3 & B & - & .021 & -- & - & $-10,000$ & - \\
\hline & 9.6 & B & -- & .023 & -- & -- & $-6,000$ & - \\
\hline & 9.9 & B & -- & .019 & - & -- & $-11,000$ & -- \\
\hline & 10.2 & B & -- & .019 & -- & -- & $-12,000$ & -- \\
\hline & 10.5 & B & -- & .023 & -- & -- & $-9,200$ & -- \\
\hline
\end{tabular}


Table 4. Results of laboratory analyses of hydrologic characteristics of drill cuttings from neutron-access boreholes--Continued

\begin{tabular}{|c|c|c|c|c|c|c|c|c|}
\hline \multirow{2}{*}{$\begin{array}{c}\text { Neutron- } \\
\text { access } \\
\text { borehole } \\
\text { number }\end{array}$} & \multirow{2}{*}{$\begin{array}{c}\text { Depth } \\
\text { (meters) }\end{array}$} & \multirow{2}{*}{ Rock type } & \multicolumn{3}{|c|}{$\begin{array}{l}\text { Gravimetric water content } \\
\text { (grams per gram) }\end{array}$} & \multicolumn{3}{|c|}{$\begin{array}{l}\text { Water potential } \\
\text { (kilopascals) }\end{array}$} \\
\hline & & & Composite & Coarse & Fine & Composite & Coarse & $F \cdot \theta$ \\
\hline USW & 0.3 & $A$ & -- & 0.048 & - & -- & -870 & - \\
\hline \multirow[t]{31}{*}{ UZ-N45 } & .8 & A & -- & .041 & -- & -- & $-1,400$ & -- \\
\hline & 1.1 & A & -- & .018 & - & -- & $-8,700$ & - \\
\hline & 1.4 & A & -- & .024 & - & -- & $-65,000$ & - \\
\hline & 1.7 & A & -- & .026 & -- & - & $-78,000$ & -- \\
\hline & 2.1 & A & - & .022 & -- & - & $-6,200$ & - \\
\hline & 2.6 & A & -- & .025 & -- & -- & $-3,600$ &.- \\
\hline & 2.9 & A & - & .054 & -- & - & -730 & - \\
\hline & 3.2 & A & -- & .065 & - & - & -800 & - \\
\hline & 3.7 & A & -- & .069 & - & -- & $-1,000$ & -- \\
\hline & 4.1 & A & - & .065 & - & -- & -830 & -- \\
\hline & 4.4 & A & - & .069 & - & -- & -890 & -. \\
\hline & 4.7 & A & - & .068 & -- & -- & -900 & $\cdots$ \\
\hline & 5.2 & A & - & .067 & - & - & -850 & - \\
\hline & 5.6 & A & -- & .063 & - & -- & -620 & -- \\
\hline & 5.9 & A & -- & .054 & - & - & -620 & - \\
\hline & 6.2 & A & -- & .050 & - & -- & -690 & - \\
\hline & 6.7 & A & - & .057 & - & -- & -590 & -- \\
\hline & 7.2 & A & -- & .056 & - & -- & -580 & -- \\
\hline & 7.5 & A & - & .058 & - & -- & -500 & -. \\
\hline & 7.9 & A & - & .069 & -- & - & -520 & - \\
\hline & 8.4 & A & - & .061 & - & - & -470 & - \\
\hline & 8.7 & A & -. & .059 & - & -- & -660 & -- \\
\hline & 9.0 & A & -- & .057 & - & - & -700 & - \\
\hline & 9.4 & A & -- & .060 & - & -- & -610 & -- \\
\hline & 9.9 & A & -- & .058 & - & -- & -580 & -- \\
\hline & 10.2 & A & -- & .058 & - & -- & -610 & -- \\
\hline & 10.5 & A & -- & .061 & - & - & -540 & -- \\
\hline & 11.0 & B & -. & .024 & - & - & $-15,000$ & -- \\
\hline & 11.7 & B & -- & .023 & - & - & $-11,000$ & -- \\
\hline & 12.6 & B & - & .022 & - & - & $-14,000$ & - \\
\hline & 13.4 & B & - & .024 & - & - & $-12,000$ & -- \\
\hline USW & .3 & B & -- & .142 & - & -- & -750 & -. \\
\hline \multirow[t]{9}{*}{ UZ-N46 } & .8 & B & -- & .154 & - & -. & -700 & -- \\
\hline & 1.1 & B & - & .178 & - & - & -670 & -- \\
\hline & 1.4 & B & -- & .146 & -. & -- & -610 & -. \\
\hline & 1.8 & B & -- & .099 & -- & - & -630 & -- \\
\hline & 2.3 & B & - & .082 & - & -- & -640 & 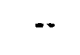 \\
\hline & 2.6 & B & -- & .092 &.- & -- & -720 & $\cdots$ \\
\hline & 2.9 & B & - & .092 & - & - & -610 & - \\
\hline & 3.4 & B & - & .048 & - & - & -850 & $\cdots$ \\
\hline & 3.8 & B & -- & -- & -- & -- & - & - \\
\hline
\end{tabular}


Table 4. Results of laboratory analyses of hydrologic characteristics of drill cuttings from neutron-access boreho'iss--Continued

\begin{tabular}{|c|c|c|c|c|c|c|c|c|}
\hline \multirow{2}{*}{$\begin{array}{c}\text { Neutron- } \\
\text { access } \\
\text { borehole } \\
\text { number }\end{array}$} & \multirow{2}{*}{$\begin{array}{c}\text { Depth } \\
\text { (meters) }\end{array}$} & \multirow{2}{*}{ Rock type } & \multicolumn{3}{|c|}{$\begin{array}{l}\text { Gravimetric water content } \\
\text { (grams per gram) }\end{array}$} & \multicolumn{3}{|c|}{$\begin{array}{l}\text { Water potential } \\
\text { (kilopascals) }\end{array}$} \\
\hline & & & Composite & Coarse & Fine & Composite & Coarse & Fine \\
\hline \multicolumn{9}{|l|}{ USW } \\
\hline \multicolumn{9}{|c|}{ UZ-N46--Continued } \\
\hline & 4.1 & B & -- & -- & -- & -- & - & - \\
\hline & 4.4 & B & -- & 0.040 & -- & -. & -940 & -- \\
\hline & 4.9 & B & - & .047 & - & - & -850 & -- \\
\hline & 5.3 & B & - & .051 & - & - & -510 & - \\
\hline & 5.6 & B & -- & .035 & - & - & -820 & - \\
\hline & 5.9 & B & -- & .038 & -- & - & -600 & -- \\
\hline & 6.4 & B & -- & .043 & - & -- & -640 & - \\
\hline & 6.9 & B & -- & .046 & -. & -. & -690 & - \\
\hline & 7.2 & B & -- & .041 & - & - & -530 & - \\
\hline & 7.5 & B & -- & .040 & - & - & -770 & - \\
\hline & 7.9 & B & - & .040 & - & -- & -720 & - \\
\hline & 8.4 & B & -- & .046 & -- & -- & -600 & - \\
\hline & 8.7 & B & -- & .044 & -- & -- & -610 & - \\
\hline & 9.0 & B & -- & .044 & -. & - & -660 & - \\
\hline & 9.4 & B & -- & .082 & -- & -- & -580 & - \\
\hline & 9.9 & B & -- & .084 & -- & -- & -450 & -. \\
\hline & 10.2 & B & -- & .084 & -- & - & -420 & - \\
\hline & 10.5 & B & -- & .076 & - & - & -470 & - \\
\hline & 11.0 & B & -- & .065 & -. & - & -410 & - \\
\hline & 11.4 & B & -- & .061 & -- & -- & -440 & - \\
\hline & 11.7 & B & -- & .067 & -. & - & -610 & - \\
\hline & 12.0 & B & -- & .073 & -- & -- & -610 & - \\
\hline & 12.5 & B & -- & .068 & -- & -- & -530 & -- \\
\hline & 13.0 & B & -- & .068 & -- & - & -560 & -- \\
\hline & 13.3 & B & -- & .067 & -- & -- & -590 & -- \\
\hline & 13.6 & B & - & .057 & -. & -- & -750 & -- \\
\hline & 14.0 & B & -. & .042 & -- & -- & -860 & -- \\
\hline & 14.5 & B & - & .045 & -- & -- & -730 & - \\
\hline & 14.8 & B & -- & .043 & -- & - & -650 & -- \\
\hline & 15.1 & B & -- & .046 & -- & - & -650 & - \\
\hline & 15.5 & B & -- & .047 & -- & -- & -840 & - \\
\hline & 16.0 & B & - & .047 & -- & -- & -790 & -- \\
\hline & 16.3 & B & -. & .042 & -. & - & $-1,600$ & -. \\
\hline & 16.6 & B & -- & .038 & -- & -- & -950 & -- \\
\hline & 16.9 & B & -- & .042 & -. & -. & -950 & - \\
\hline & 17.2 & B & - & .039 & -. & .- & $-1,800$ & -. \\
\hline & 17.5 & B & -- & .035 & -- & -- & $-2,400$ & - \\
\hline & 17.8 & B & -- & .033 & -- & .- & $-2,700$ & - \\
\hline & 18.1 & B & -- & .039 & -- & -- & $-1,800$ & - \\
\hline & 18.4 & B & -- & .040 & -- & -- & -960 & -- \\
\hline & 18.7 & B & -- & .039 & -- & -. & $-1,000$ & - \\
\hline
\end{tabular}


Table 4. Results of laboratory analyses of hydrologic characteristics of drill cuttings from neutron-access boreholes--Continued

\begin{tabular}{|c|c|c|c|c|c|c|c|c|}
\hline \multirow{2}{*}{$\begin{array}{c}\text { Neutron- } \\
\text { access } \\
\text { borehole } \\
\text { number }\end{array}$} & \multirow{2}{*}{$\begin{array}{c}\text { Depth } \\
\text { (meters) }\end{array}$} & \multirow{2}{*}{ Rock type } & \multicolumn{3}{|c|}{$\begin{array}{l}\text { Gravimetrlc water content } \\
\text { (grams per gram) }\end{array}$} & \multicolumn{3}{|c|}{$\begin{array}{l}\text { Water potentlal } \\
\text { (kllopascals) }\end{array}$} \\
\hline & & & Composite & Coarse & Fine & Composite & Coarse & FI-e \\
\hline \multicolumn{9}{|c|}{ USW } \\
\hline \multicolumn{9}{|c|}{ UZ-N46--Continued } \\
\hline & 19.0 & B & -- & 0.039 & -- & -- & -910 & -- \\
\hline & 19.4 & B & -- & .042 & -- & -- & -900 & -- \\
\hline & 19.7 & B & -- & .044 & -- & -- & $-1,300$ & -- \\
\hline & 20.0 & B & -- & .040 & - & -- & $-1,800$ & -- \\
\hline & 20.3 & B & -- & .045 & - & -- & $-1,000$ & -- \\
\hline & 20.6 & B & -- & .048 & - & -- & $-1,200$ & - \\
\hline & 20.9 & B & -- & .049 & -- & -. & $-1,300$ & -- \\
\hline & 21.2 & B & -- & .047 & -- & -. & $-2,100$ & -- \\
\hline & 21.5 & B & -- & .052 & - &.- & $-1,900$ & - \\
\hline & 21.8 & B & -- & .055 & - & - & $-2,600$ & - \\
\hline & 22.1 & B & -- & .065 & -- & -- & $-2,100$ & - \\
\hline & 22.4 & B & - & .067 & -- & $\cdots$ & $-1,700$ & -- \\
\hline & 22.7 & B & - & .066 & - & -. & $-2,000$ & - \\
\hline & 23.0 & B & -- & .097 & - & -- & $-1,200$ & $*$ \\
\hline & 23.3 & B & -- & .258 & - & -- & -670 & -- \\
\hline & 23.6 & B & -- & .243 & - & -- & $-2,800$ & -- \\
\hline & 23.9 & B & -- & .216 & - & -- & $-1,000$ & - \\
\hline & 24.2 & B & -- & .172 & - & -- & $-1,000$ & - \\
\hline & 24.5 & B & -- & .213 & -- & -- & -720 & - \\
\hline & 24.8 & B & -. & .231 & -- & -. & -650 & - \\
\hline & 25.1 & B & -- & .274 & -- & -- & -490 & - \\
\hline & 25.5 & B & -- & .290 & - & -- & -470 & - \\
\hline & 25.9 & B & -- & .259 & - & -- & -530 & - \\
\hline & 26.5 & B & -- & .191 & - & -- & -600 & - \\
\hline & 27.1 & B & -- & .132 & -- & - & -460 & - \\
\hline & 27.7 & B & -- & .185 & -- & -. & -520 & -- \\
\hline & 28.3 & B & -- & .131 & -- & -- & -420 & -- \\
\hline & 29.0 & B & -- & .170 & - & - & -510 & -- \\
\hline & 29.6 & B & -- & .164 & -- & -. & -490 & -- \\
\hline & 30.0 & B & -- & .160 & -- & - & -470 & - \\
\hline USW & 0.3 & A & -- & .060 & -- & -- & -660 & -- \\
\hline \multirow[t]{9}{*}{ UZ-N47 } & .8 & A & - & .061 & -- & -. & -580 & -- \\
\hline & 1.1 & A & -- & .064 & - & -- & -650 & -- \\
\hline & 1.4 & A & -- & .054 & - & -- & -860 & -- \\
\hline & 1.8 & A & -- & .065 & - & -- & -640 & -- \\
\hline & 2.3 & A & -- & .068 & - & -- & -670 & -- \\
\hline & 2.6 & A & -- & .068 & - & -- & -680 & -- \\
\hline & 2.9 & A & -- & .063 & -- & -- & -730 & -- \\
\hline & 3.4 & A & -- & .066 & - & -- & -560 & - \\
\hline & 3.8 & A & -- & .064 & - & - & -560 & -- \\
\hline
\end{tabular}


Table 4. Results of laboratory analyses of hydrologic characteristics of drill cuttings from neutron-access borehcles--Continued

\begin{tabular}{|c|c|c|c|c|c|c|c|c|}
\hline \multirow{2}{*}{$\begin{array}{c}\text { Neutron- } \\
\text { access } \\
\text { borehole } \\
\text { number }\end{array}$} & \multirow{2}{*}{$\begin{array}{c}\text { Depth } \\
\text { (meters) }\end{array}$} & \multirow{2}{*}{ Rock type } & \multicolumn{3}{|c|}{$\begin{array}{l}\text { Gravimetric water content } \\
\text { (grams per gram) }\end{array}$} & \multicolumn{3}{|c|}{$\begin{array}{l}\text { Water potential } \\
\text { (kllopascals) }\end{array}$} \\
\hline & & & Composite & Coarse & Fine & Composite & Coarse & Fine \\
\hline \multicolumn{9}{|c|}{ USW } \\
\hline \multicolumn{9}{|c|}{ UZ-N47-Continued } \\
\hline & 4.1 & $\mathbf{A}$ & -- & .056 & -- & -- & -670 & - \\
\hline & 4.4 & A & -- & 0.054 & - & -- & $-1,200$ & - \\
\hline & 4.9 & A & - & .025 & -- & - & $-4,700$ & - \\
\hline & 5.3 & A & -- & .020 & - & - & $-9,300$ & - \\
\hline & 5.6 & A & -- & .019 & - & - & $-8,200$ & - \\
\hline & 5.9 & A & - & .022 & -- & - & $-5,500$ & - \\
\hline & 6.4 & A & - & .018 & -- & -- & $-10,000$ & - \\
\hline & 6.9 & A & - & .020 & -- & - & $-9,400$ & -- \\
\hline & 7.2 & A & - & .019 & -- & - & $-15,000$ & -- \\
\hline & 7.5 & A & - & .018 & -- & - & $-12,000$ & - \\
\hline & 7.9 & A & - & .024 & -- & - & $-11,000$ & -- \\
\hline & 8.4 & A & -- & .033 & -- & - & $-2,200$ & -- \\
\hline & 8.7 & A & - & .034 & - & - & $-2,600$ & -- \\
\hline & 9.0 & A & -- & .031 & - & - & $-4,000$ & - \\
\hline & 9.4 & A & - & .034 & - & - & $-3,200$ & - \\
\hline & 9.9 & A & - & .035 & - & - & $-4,500$ & - \\
\hline & 10.2 & B & -- & .028 & - & - & $-7,500$ & - \\
\hline & 10.5 & B & -- & .023 & - & - & $-5,900$ & - \\
\hline & 11.0 & B & -- & .034 & - & - & -820 & - \\
\hline & 11.4 & B & -- & .034 & -- & -. & -960 & -- \\
\hline & 11.7 & B & -- & .050 & -- & - & -610 & - \\
\hline & 12.0 & B & -- & .039 & -- & - & -730 & - \\
\hline & 12.0 & B & -- & - & -- & - & -770 & - \\
\hline & 12.5 & B & -- & .060 & -- & - & -700 & -- \\
\hline & 13.0 & B & - & .052 & -- & - & -710 & - \\
\hline & 13.3 & B & - & .048 & - & - & -720 & - \\
\hline & 13.6 & B & -- & .052 & - & -- & -690 & - \\
\hline & 14.0 & B & - & .061 & -- & - & -660 & - \\
\hline & 14.5 & B & - & .054 & -- & - & -790 & - \\
\hline & 14.8 & B & -- & .057 & -- & - & -660 & - \\
\hline & 15.1 & B & - & .068 & - & - & -560 & - \\
\hline & 15.5 & B & -- & .061 & -- & - & -600 & - \\
\hline & 16.0 & B & -- & .057 & -- & - & -660 & -- \\
\hline & 16.3 & B & - & .055 & -- & - & -880 & - \\
\hline & 16.6 & B & -- & .051 & -- & - & -950 & - \\
\hline & 17.1 & B & - & .047 & -- & - & -910 & - \\
\hline & 17.5 & B & -- & .039 & -- & - & $-1,200$ & -- \\
\hline & 17.8 & B & - & .036 & -- & - & $-2,100$ & - \\
\hline & 18.1 & B & - & .046 & - & -- & -940 & -- \\
\hline & 18.6 & B & -- & .048 & - & -- & $-1,300$ & - \\
\hline
\end{tabular}


Table 4. Results of laboratory analyses of hydrologic characteristics of drill cuttings from neutron-access boreholes--Continued

\begin{tabular}{|c|c|c|c|c|c|c|c|c|}
\hline \multirow{2}{*}{$\begin{array}{l}\text { Neutron- } \\
\text { access } \\
\text { borehoie } \\
\text { number }\end{array}$} & \multirow{2}{*}{$\begin{array}{l}\text { Depth } \\
\text { (meters) }\end{array}$} & \multirow{2}{*}{$\begin{array}{l}\text { Rock } \\
\text { type }\end{array}$} & \multicolumn{3}{|c|}{$\begin{array}{l}\text { Gravimetric water content } \\
\text { (grams per gram) }\end{array}$} & \multicolumn{3}{|c|}{$\begin{array}{l}\text { Water potential } \\
\text { (kilopascals) }\end{array}$} \\
\hline & & & Composite & Coarse & Fine & Composite & Coarse & Fine \\
\hline \multicolumn{9}{|c|}{$\overline{\mathrm{USW}}$} \\
\hline \multicolumn{9}{|c|}{ UZ-N47--Continued } \\
\hline & 19.0 & B & -- & 0.045 & - & -- & $-2,100$ & -- \\
\hline & 19.4 & B & -- & .051 & - & -- & $-1,800$ & -- \\
\hline & 19.7 & B & $-\cdot$ & .057 & -- & -- & $-1,300$ & -- \\
\hline & 20.0 & B & -- & .065 & -- & - & -910 & -- \\
\hline & 20.3 & B & -- & .071 & -- & - & -980 & -- \\
\hline & 20.6 & $\mathbf{B}$ & -- & .082 & -- & -- & -900 & - \\
\hline & 20.9 & $\mathbf{B}$ & - & .116 & -- & $\cdots$ & -790 & - \\
\hline & 21.2 & B & 0.152 & .180 & -- & -- & $-3,400$ & - \\
\hline & 21.6 & B & -- & .230 & -- & - & -780 & -- \\
\hline & 22.3 & B & -- & .215 & -- & - & -720 & - \\
\hline & 22.9 & B & -- & .249 & -- & - & -640 & - \\
\hline & 23.5 & B & -- & .247 & - & -- & -560 & - \\
\hline & 24.1 & B & - & .228 & - & -- & -660 & - \\
\hline & 24.7 & B & -- & .175 & -- & -- & -640 & -- \\
\hline & 23.5 & B & -- & .247 & $\cdots$ & - & -560 & - \\
\hline & 24.1 & B & -- & .228 & -- & -- & -660 & -- \\
\hline & 24.7 & B & -- & .175 & - & -- & -640 & -- \\
\hline & 25.3 & B & -- & .163 & - & -- & -740 & -- \\
\hline & 25.8 & B & -- & .168 & -- & -- & $-1,300$ & - \\
\hline USW & 0.5 & B & - & .018 & -- & - & $-33,000$ & - \\
\hline \multirow[t]{17}{*}{ UZ-N48 } & 1.1 & B & -- & .016 & -- & - & $-60,000$ & -- \\
\hline & 1.4 & B & -- & .013 & -- & -- & $-36,000$ & - \\
\hline & 1.7 & B & -- & .011 & -- & -- & $-56,000$ & - \\
\hline & 2.0 & B & -- & .030 & -- & -- & $-8,900$ & -- \\
\hline & 2.3 & B & -- & .026 & -- & - & $-9,500$ & -- \\
\hline & 2.6 & B & -- & .026 & -- & - & $-8,300$ & -- \\
\hline & 2.9 & B & -- & .025 & -- & -- & $-13,000$ & - \\
\hline & 3.2 & B & - & .024 & - & -- & $-13,000$ & -- \\
\hline & 3.5 & B & -- & .025 & -- & -- & $-9,800$ & -- \\
\hline & 3.8 & B & - & .024 & $\cdots$ & -- & $-15,000$ & -- \\
\hline & 4.1 & B & -- & .025 & -- & - & $-13,000$ & -- \\
\hline & 4.4 & B & -- & .025 & - & -- & $-9,900$ & -- \\
\hline & 4.7 & B & -- & .020 & - & - & $-13,000$ & - \\
\hline & 5.0 & B & -- & .023 & - & $-\cdot$ & $-10,000$ & - \\
\hline & 5.3 & B & -- & .022 & -- & -. & $-11,000$ & -- \\
\hline & 5.6 & B & - & .028 & -- & $-\cdot$ & $-9,600$ & -- \\
\hline & 5.9 & B & - & .025 & -- & -- & $-10,000$ & - \\
\hline
\end{tabular}


Table 4. Results of laboratory analyses of hydrologic characteristics of drill cuttings from neutron-access boreholes--Continued

\begin{tabular}{|c|c|c|c|c|c|c|c|c|}
\hline \multirow{2}{*}{$\begin{array}{c}\text { Neutron- } \\
\text { access } \\
\text { borehole } \\
\text { number }\end{array}$} & \multirow{2}{*}{$\begin{array}{c}\text { Depth } \\
\text { (meters) }\end{array}$} & \multirow{2}{*}{$\begin{array}{l}\text { Rock } \\
\text { type }\end{array}$} & \multicolumn{3}{|c|}{$\begin{array}{l}\text { Gravimetric water content } \\
\text { (grams per gram) }\end{array}$} & \multicolumn{3}{|c|}{$\begin{array}{l}\text { Water potential } \\
\text { (kilopascals) }\end{array}$} \\
\hline & & & Composite & Coarse & Fine & Composite & Coarse & Fine \\
\hline \multicolumn{9}{|l|}{$\overline{\mathrm{USW}}$} \\
\hline \multicolumn{9}{|c|}{ UZ-N48--Continued } \\
\hline & 6.2 & B & -- & 0.022 & -- & -- & $-12,000$ & - \\
\hline & 6.6 & B & -- & .020 & -- & - & $-17,000$ & - \\
\hline & 6.9 & B & - & .018 & - & - & $-22,000$ & -- \\
\hline & 7.2 & B & -- & .019 & -. & -- & $-15,000$ & -- \\
\hline & 7.5 & B & - & .016 & -- & -- & $-27,000$ & -- \\
\hline & 7.8 & B & -- & .020 & - & - & $-12,000$ & -- \\
\hline & 8.1 & B & -- & .022 & -- & -- & $-9,900$ & -- \\
\hline & 8.4 & B & -- & .025 & -- & - & $-9,000$ & -- \\
\hline & 8.7 & B & - & .019 & - & - & $-10,000$ & -- \\
\hline & 9.0 & B & -- & .020 & -- & -- & $-13,000$ &.- \\
\hline & 9.3 & B & -- & .019 & -- & -- & $-17,000$ & -- \\
\hline & 9.6 & B & - & .016 & -- & -- & $-24,000$ & -- \\
\hline & 9.9 & B & -- & .018 & -- & -- & $-14,000$ & -- \\
\hline & 10.2 & B & -- & .015 & -- & - & $-15,000$ & - \\
\hline & 10.5 & B & -- & .018 & -- & -- & $-24,000$ & - \\
\hline USW & 0.3 & A & -- & -- & -- & -- & -- & -- \\
\hline \multirow[t]{23}{*}{ UZ-N49 } & .8 & B & -- & .030 & -. & -- & $-8,200$ & -- \\
\hline & 1.1 & B & -- & .039 & -- & -- & $-4,900$ & $\cdots$ \\
\hline & 1.4 & B & -- & .028 & -- & -- & $-8,500$ & -- \\
\hline & 1.7 & B & -- & .032 & -- & -- & $-7,300$ & - \\
\hline & 2.0 & B & - & .032 & -- & -- & $-6,400$ & -- \\
\hline & 2.3 & B & -- & .023 & -- & -- & $-9,400$ & -- \\
\hline & 2.6 & B & -- & .024 & -- & -- & $-11,000$ & -- \\
\hline & 2.9 & B & -- & .024 & -- & -- & $-13,000$ & -- \\
\hline & 3.2 & B & - & .024 & -- & -- & $-15,000$ & -- \\
\hline & 3.5 & B & -- & .023 & -- & -- & $-18,000$ & -- \\
\hline & 3.5 & B & -- & -- & -- & -- & $-21,000$ & -- \\
\hline & 3.8 & B & -- & .020 & -- & -- & $-27,000$ & -- \\
\hline & 3.8 & B & -- & .020 & -- & -- & $-31,000$ & -- \\
\hline & 4.1 & B & -- & .023 & -- & -- & $-14,000$ & -- \\
\hline & 4.1 & B & -- & .023 & -- & -- & $-16,000$ & -- \\
\hline & 4.4 & B & -- & .029 & -- & -- & $-8,700$ & -- \\
\hline & 4.7 & B & -- & .029 & -- & -- & $-7,600$ & - \\
\hline & 5.0 & B & -- & .028 & -- & -- & $-8,900$ & -- \\
\hline & 5.3 & B & -- & .026 & -- & - & $-13,000$ & -- \\
\hline & 5.6 & B & -- & .026 & -- & -- & $-11,000$ & -- \\
\hline & 5.9 & B & -- & .025 & -- & -- & $-13,000$ & -- \\
\hline & 6.2 & B & -- & .029 & -- & -- & $-9,000$ & -- \\
\hline & 6.6 & B & -- & .024 & -. & -- & $-9,800$ & -- \\
\hline
\end{tabular}


Table 4. Results of laboratory analyses of hydrologic characteristics of drill cuttings from neutron-access boreholes--Continued

\begin{tabular}{|c|c|c|c|c|c|c|c|c|}
\hline \multirow{2}{*}{$\begin{array}{c}\text { Neutron- } \\
\text { access } \\
\text { borehole } \\
\text { number }\end{array}$} & \multirow{2}{*}{$\begin{array}{c}\text { Depth } \\
\text { (meters) }\end{array}$} & \multirow{2}{*}{$\begin{array}{l}\text { Rock } \\
\text { type }\end{array}$} & \multicolumn{3}{|c|}{$\begin{array}{l}\text { Gravimetric water content } \\
\text { (grams per gram) }\end{array}$} & \multicolumn{3}{|c|}{$\begin{array}{l}\text { Water potentlal } \\
\text { (kliopascais) }\end{array}$} \\
\hline & & & Composite & Coarse & Fine & Composite & Coarse & Fina \\
\hline \multicolumn{9}{|l|}{ USW } \\
\hline \multicolumn{9}{|c|}{ UZ-N49--Continued } \\
\hline & 6.9 & B & -- & 0.027 & -- & -- & $-9,100$ & - \\
\hline & 7.2 & B & -- & .030 & -- & -- & $-6,100$ & - \\
\hline & 7.5 & B & -- & .033 & -- & -- & $-4,000$ & - \\
\hline & 7.8 & B & -- & .032 & -- & -- & $-5,300$ & - \\
\hline & 8.1 & B & -- & .030 & - & -- & $-8,800$ & - \\
\hline & 8.4 & B & - & - & - & -- & - & - \\
\hline & 8.7 & B & -- & .026 & - & -- & $-12,000$ & - \\
\hline & 9.0 & B & -- & .027 & - & -- & $-8,500$ & - \\
\hline & 9.0 & B & -- & -- & - & -- & $-9,000$ & - \\
\hline & 9.3 & B & -- & .030 & - & - & $-4,100$ & - \\
\hline & 9.6 & B & -- & .033 & - & -- & $-4,000$ & - \\
\hline & 9.9 & B & -- & .035 & - & -. & $-1,900$ & - \\
\hline & 10.2 & B & - & .036 & - & -- & $-1,700$ & - \\
\hline & 10.5 & B & -- & .036 & - & -- & $-2,300$ & - \\
\hline USW & 0.6 & A & 0.107 & .098 & .144 & - & -- & - \\
\hline \multirow[t]{19}{*}{ UZ-N50 } & .6 & A & .112 & .105 & - & -- & - & - \\
\hline & 1.2 & A & .082 & .070 & .095 & -- & -- & - \\
\hline & 1.2 & A & .085 & .077 & - & -- & -- & - \\
\hline & 1.8 & A & .082 & .068 & .096 & - & -- & -- \\
\hline & 1.8 & A & .080 & .072 & -- & - & -- & - \\
\hline & 2.4 & A & .091 & .074 & .119 & -- & -. & -. \\
\hline & 2.4 & A & .086 & .084 & - & -- & - & - \\
\hline & 3.0 & B & .042 & .037 & .045 & -- & - & - \\
\hline & 3.0 & B & .044 & .036 & -- & -- & - & - \\
\hline & 3.7 & B & .033 & .033 & .030 & -- & -- & - \\
\hline & 3.7 & B & .032 & .032 & -- & -- & -- & -- \\
\hline & 4.3 & B & .020 & .023 & .016 & -- & - & - \\
\hline & 4.3 & B & .020 & .022 & - & - & - & - \\
\hline & 4.9 & B & .020 & .022 & .016 & -- & - & - \\
\hline & 4.9 & B & .019 & .021 & - & - & -- & - \\
\hline & 5.5 & B & .021 & .025 & .015 & - & -- & - \\
\hline & 5.5 & B & .021 & .024 & -- & - & -- & - \\
\hline & 6.1 & B & .023 & .026 & .020 & -- & -. & - \\
\hline & 6.1 & B & .024 & .027 & - & -- & -. & - \\
\hline USW & .6 & A & .055 & - & .047 & -- & -- & - \\
\hline \multirow[t]{2}{*}{ UZ-N51 } & .6 & A & .060 & -- & - & - & -- & - \\
\hline & 1.2 & A & .068 & .064 & .061 & - & -- & - \\
\hline
\end{tabular}


Table 4. Results of laboratory analyses of hydrologic characteristics of drill cuttings from neutron-access boreho'es--Continued

\begin{tabular}{|c|c|c|c|c|c|c|c|c|}
\hline \multirow{2}{*}{$\begin{array}{c}\text { Neutron- } \\
\text { access } \\
\text { borehole } \\
\text { number }\end{array}$} & \multirow{2}{*}{$\begin{array}{c}\text { Depth } \\
\text { (meters) }\end{array}$} & \multirow{2}{*}{$\begin{array}{l}\text { Rock } \\
\text { type }\end{array}$} & \multicolumn{3}{|c|}{$\begin{array}{l}\text { Gravimetric water content } \\
\text { (grams per gram) }\end{array}$} & \multicolumn{3}{|c|}{$\begin{array}{l}\text { Water potential } \\
\text { (kllopascals) }\end{array}$} \\
\hline & & & Composite & Coarse & Fine & Composite & Coarse & Fine \\
\hline \multicolumn{9}{|c|}{ USW } \\
\hline \multicolumn{9}{|c|}{ UZ-N51--Continued } \\
\hline & 1.2 & A & 0.068 & 0.066 & -- & -- & - & - \\
\hline & 1.8 & A & .074 & .070 & 0.077 & -- & - & - \\
\hline & 1.8 & A & .076 & .075 & -- & - & - & - \\
\hline & 2.4 & A & .080 & .074 & .092 & - & - & -- \\
\hline & 2.4 & A & .078 & .077 & - & - & - & - \\
\hline & 3.0 & A & .084 & .077 & .096 & $\cdots$ & $\cdots$ & $\cdots$ \\
\hline & 3.0 & A & .083 & .080 &.- & - & -- & - \\
\hline & 3.7 & A & .086 & .084 & .114 & -. & - & -. \\
\hline & 3.7 & A & .087 & .079 & -- & - & - & $\cdots$ \\
\hline & 4.3 & B & .060 & .051 & .073 & - & - & - \\
\hline & 4.3 & B & .059 & .049 & -- & -- & - & -- \\
\hline & 4.9 & B & .035 & .041 & .035 & -. & - & - \\
\hline & 4.9 & B & .036 & .034 & - & - & - & - \\
\hline & 5.5 & B & .022 & .023 & .022 & - & - & - \\
\hline & 5.5 & B & .023 & .023 & -- & -- & - & -- \\
\hline & 6.1 & B & .023 & .024 & .021 & - & - & - \\
\hline & 6.1 & B & .025 & .023 & - & - & - & - \\
\hline USW & 0.6 & A & .059 & - & .077 & -- & - & - \\
\hline \multirow[t]{21}{*}{ UZ-N52 } & .6 & A & .063 & - & - & .. & - &.- \\
\hline & 1.2 & A & .065 & .058 & .074 & -- & - & -- \\
\hline & 1.2 & A & .065 & .063 & -- & - & - & - \\
\hline & 1.8 & A & .069 & .067 & .070 & - & - & - \\
\hline & 1.8 & A & .068 & .065 & -- & -- & - & -- \\
\hline & 2.4 & B & .024 & .027 & .132 & - & - & -- \\
\hline & 2.4 & B & .024 & - & -- & - & - & - \\
\hline & 3.0 & B & .024 & .026 & .023 & -- & - & -- \\
\hline & 3.0 & B & .024 & .030 & -- & - & - & -- \\
\hline & 3.7 & B & .024 & .024 & .021 & -- & - & -- \\
\hline & 3.7 & B & .024 & .031 & -. & -- & - & - \\
\hline & 4.3 & B & .021 & .023 & .019 & - & - & - \\
\hline & 4.3 & B & .027 & .022 & -- & - & - & - \\
\hline & 4.9 & B & .017 & .020 & .014 & -- & -- & -- \\
\hline & 4.9 & B & .017 & .019 & -- & -- & -- & -- \\
\hline & 5.5 & B & .015 & .019 & .013 & - & - & -- \\
\hline & 5.5 & B & .017 & .018 & - & - & - & -- \\
\hline & 6.1 & B & .017 & .019 & .013 & -- & - & -. \\
\hline & 6.1 & B & .017 & .017 & -- & -. & - & - \\
\hline & 6.7 & B & .016 & .017 & .012 & -- & - & - \\
\hline & 6.7 & B & .016 & .018 & -- & -. & -. & - \\
\hline
\end{tabular}


Table 4. Results of laboratory analyses of hydrologic characteristics of drill cuttings from neutron-access boreholes--Continued

\begin{tabular}{|c|c|c|c|c|c|c|c|c|}
\hline \multirow{2}{*}{$\begin{array}{l}\text { Neutron- } \\
\text { access } \\
\text { borehole } \\
\text { number }\end{array}$} & \multirow{2}{*}{$\begin{array}{l}\text { Depth } \\
\text { (meters) }\end{array}$} & \multirow{2}{*}{$\begin{array}{l}\text { Rock } \\
\text { type }\end{array}$} & \multicolumn{3}{|c|}{$\begin{array}{l}\text { Gravimetric water content } \\
\text { (grams per gram) }\end{array}$} & \multicolumn{3}{|c|}{$\begin{array}{l}\text { Water potentlal } \\
\text { (kllopascals) }\end{array}$} \\
\hline & & & Composite & Coarse & Fine & Composite & Coarse & Fira \\
\hline \multicolumn{9}{|c|}{$\overline{\text { USW }}$} \\
\hline \multicolumn{9}{|c|}{ UZ-N52--Continued } \\
\hline & 7.3 & B & 0.018 & 0.017 & 0.012 & - & -- & - \\
\hline & 7.3 & B & .017 & .018 & - & - & -- & $\cdots$ \\
\hline UE-25 & 0.6 & A & .056 & .059 & .055 & - & -590 & - \\
\hline \multirow[t]{36}{*}{ UZN \#56 } & .6 & A & .059 & - & - & - & -- & - \\
\hline & 1.2 & A & .043 & .041 & .049 & - & -520 & - \\
\hline & 1.2 & A & .043 & .041 & - & - & - & - \\
\hline & 1.8 & A & .044 & .042 & .050 & -- & $-1,500$ & - \\
\hline & 1.8 & A & .044 & .041 & - & - & - & - \\
\hline & 2.4 & A & .048 & .046 & .050 & -- & -570 & - \\
\hline & 2.4 & A & .048 & .049 & -- & - & - & - \\
\hline & 3.0 & A & .054 & .051 & .057 & - & -790 & $-\infty$ \\
\hline & 3.0 & A & .055 & .051 & - & -- & - & - \\
\hline & 3.7 & A & .059 & .053 & .071 & -- & $<-50$ & - \\
\hline & 3.7 & A & .060 & .055 & - & -- & -- & - \\
\hline & 4.3 & A & .070 & .068 & .083 & -- & -570 & - \\
\hline & 4.3 & $\mathbf{A}$ & .071 & .071 & -- & -- & -- & - \\
\hline & 4.9 & A & .066 & .063 & .066 & - & -590 & - \\
\hline & 4.9 & A & .067 & .068 & - & -- & - & - \\
\hline & 5.5 & A & .065 & .062 & .077 & -- & -740 & - \\
\hline & 5.5 & A & .066 & .064 & -- & -- & - & - \\
\hline & 6.1 & A & .067 & .062 & .083 & - & -330 & - \\
\hline & 6.1 & A & .068 & .064 & - & - & - & - \\
\hline & 6.7 & A & .054 & .050 & .064 & - & -350 & - \\
\hline & 6.7 & A & .055 & .051 & - & - & -- & - \\
\hline & 7.3 & A & .052 & .051 & .071 & - & -320 & - \\
\hline & 7.3 & A & .053 & .051 & - & - & -- & - \\
\hline & 7.9 & A & .050 & .047 & .068 & - & $-8,800$ & - \\
\hline & 7.9 & A & .051 & .048 & - & -- & -- & - \\
\hline & 8.5 & A & .039 & .039 & .051 & - & -760 & - \\
\hline & 8.5 & A & .042 & .040 & - & - & -- & - \\
\hline & 9.1 & A & .053 & .052 & .058 & -- & -300 & - \\
\hline & 9.1 & A & .053 & .049 & - & - & - & - \\
\hline & 9.8 & A & .053 & .053 & .047 & -- & -570 & - \\
\hline & 9.8 & A & .049 & - & .048 & - & - & - \\
\hline & 10.4 & A & .047 & .046 & .046 & -- & -900 & - \\
\hline & 10.4 & A & .046 & .045 & -- & -- & -- & - \\
\hline & 11.0 & A & .046 & .046 & .047 & -- & -250 & - \\
\hline & 11.0 & A & .046 & .047 & - & - & -530 & - \\
\hline & 11.6 & A & .052 & .049 & .054 & -- & $-14,000$ & - \\
\hline
\end{tabular}


Table 4. Results of laboratory analyses of hydrologic characteristics of drill cuttings from neutron-access borehcles--Continued

\begin{tabular}{|c|c|c|c|c|c|c|c|c|}
\hline \multirow{2}{*}{$\begin{array}{l}\text { Neutron- } \\
\text { access } \\
\text { borehole } \\
\text { number }\end{array}$} & \multirow{2}{*}{$\begin{array}{l}\text { Depth } \\
\text { (meters) }\end{array}$} & \multirow{2}{*}{$\begin{array}{l}\text { Rock } \\
\text { type }\end{array}$} & \multicolumn{3}{|c|}{$\begin{array}{l}\text { Gravimetrlc water content } \\
\text { (grams per gram) }\end{array}$} & \multicolumn{3}{|c|}{$\begin{array}{l}\text { Water potentlal } \\
\text { (kilopascals) }\end{array}$} \\
\hline & & & Composite & Coarse & Fine & Composite & Coarse & Fine \\
\hline \multicolumn{9}{|c|}{ UE-25 } \\
\hline \multicolumn{9}{|c|}{ UZN \#56--Continued } \\
\hline & 11.6 & A & 0.052 & 0.053 & -- & - & -- & -- \\
\hline & 12.2 & A & .060 & .054 & .071 & -- & -360 & - \\
\hline & 12.2 & A & .060 & .055 &.- & -- & - & -- \\
\hline & 12.8 & A & .068 & .060 & .081 & -- & -540 & -- \\
\hline & 12.8 & A & .065 & .064 & - & - & - & - \\
\hline & 13.4 & A & .071 & .062 & .094 & - & -240 & -- \\
\hline & 13.4 & A & .070 & .064 & - & - & - & -- \\
\hline & 14.0 & A & .061 & .055 & .079 & -- & -290 & - \\
\hline & 14.0 & A & .061 & .055 & -- & - & -- & -- \\
\hline & 14.6 & A & .053 & .051 & .059 & -- & -310 & -- \\
\hline & 14.6 & A & .050 & .050 & -- & -- & - & -- \\
\hline & 15.2 & A & .052 & .049 & .072 & - & -270 & -- \\
\hline & 15.2 & A & .051 & .051 & - & -- & -- & - \\
\hline & 15.8 & A & .056 & .046 & .036 & - & -240 & -- \\
\hline & 15.8 & A & .059 & - & .059 & -- & -- &.- \\
\hline & 16.5 & A & .064 & .037 & .071 & - & -330 & - \\
\hline & 16.5 & A & .052 & - & .075 & -- & -- & -- \\
\hline & 17.1 & B & .045 & .040 & .061 & - & -300 & -- \\
\hline & 17.1 & B & .038 & .037 & - & - & - & -- \\
\hline & 17.7 & B & .036 & .037 & .037 & - & -610 & - \\
\hline & 17.7 & B & .035 & .038 & -- & -- & -- & -- \\
\hline & 18.3 & B & .021 & .023 & .020 & - & $-2,300$ & -- \\
\hline & 18.3 & B & .021 & .023 & .021 & -- & - & - \\
\hline UE-25 & 1.2 & A & .053 & .052 & .074 & - & -160 & -- \\
\hline \multirow[t]{15}{*}{$\mathrm{UZN} \# 60$} & 1.2 & A & .054 & .049 & -- & -- & - & -- \\
\hline & 1.8 & A & .059 & .055 & .077 & -- & -120 & -. \\
\hline & 1.8 & A & .062 & .056 & -- & -- & -- & -- \\
\hline & 2.4 & A & .068 & .060 & .089 & - & -280 & -- \\
\hline & 2.4 & A & .070 & .066 & - & - & -- & -- \\
\hline & 3.0 & A & .064 & .068 & .056 & - & -200 & -- \\
\hline & 3.0 & A & .063 & - & - & -- & - & -- \\
\hline & 3.7 & A & .070 & .067 & .080 & .- & -160 & -- \\
\hline & 3.7 & A & .070 & .069 & -- & .- & - & -- \\
\hline & 4.3 & A & .069 & .062 & .083 & -- & -420 & -- \\
\hline & 4.3 & A & .072 & .065 & -- & -- & - & -- \\
\hline & 4.9 & A & .059 & .054 & .065 & .- & -120 & -- \\
\hline & 4.9 & A & .059 & .056 & - & -- & -- & -- \\
\hline & 5.5 & A & .066 & .058 & .088 & -. & -280 & -- \\
\hline & 5.5 & A & .069 & .058 & .. & - & - & $\ldots$ \\
\hline
\end{tabular}


Table 4. Results of laboratory analyses of hydrologic characteristics of drill cuttings from neutron-access boreholes--Cc ntinued

\begin{tabular}{|c|c|c|c|c|c|c|c|c|}
\hline \multirow{2}{*}{$\begin{array}{c}\text { Neutron- } \\
\text { access } \\
\text { borehole } \\
\text { number }\end{array}$} & \multirow{2}{*}{$\begin{array}{c}\text { Depth } \\
\text { (meters) }\end{array}$} & \multirow{2}{*}{$\begin{array}{l}\text { Rock } \\
\text { type }\end{array}$} & \multicolumn{3}{|c|}{$\begin{array}{l}\text { Gravimetric water content } \\
\text { (grams per gram) }\end{array}$} & \multicolumn{3}{|c|}{$\begin{array}{l}\text { Water potential } \\
\text { (kilopascals) }\end{array}$} \\
\hline & & & Composite & Coarse & Fine & Composite & Coarse & FIne \\
\hline \multicolumn{9}{|l|}{ UE-25 } \\
\hline \multicolumn{9}{|c|}{ UZN \#60--Continued } \\
\hline & 6.1 & A & 0.069 & 0.064 & 0.086 & -- & -180 & - \\
\hline & 6.1 & $\mathbf{A}$ & .071 & .060 & - & -- & -- & - \\
\hline & 6.7 & $\mathbf{A}$ & .080 & .067 & .094 & - & -110 & - \\
\hline & 6.7 & A & .077 & -- & -- & -- & -- & - \\
\hline & 7.3 & A & .073 & .067 & .089 & -- & -100 & - \\
\hline & 7.3 & A & .073 & .068 & -. & - & - & - \\
\hline & 7.9 & A & .045 & .042 & .054 & -- & -420 & - \\
\hline & 7.9 & A & .045 & .043 & -- & -- & -- & - \\
\hline & 8.5 & B & .035 & .038 & .034 & -- & -420 & - \\
\hline & 8.5 & B & .036 & .037 & -- & -- & - & - \\
\hline & 9.1 & B & .031 & .031 & .024 & -- & $-2,700$ & - \\
\hline & 9.1 & B & .032 & .030 & - & -- & -- & - \\
\hline & 9.8 & B & .033 & .034 & - & -- & $-1,800$ & - \\
\hline & 9.8 & B & .034 & -- & -- & -- & - & - \\
\hline & 10.4 & B & .032 & .033 & .030 & -- & -600 & - \\
\hline & 10.4 & B & .033 & .033 & - & -- & -- & - \\
\hline USW & 0.9 & B & -- & .028 & - & -- & -420 & - \\
\hline \multirow{23}{*}{ UZ-N65 } & 1.5 & B & -- & .037 & -- & -- & -510 & - \\
\hline & 2.1 & B & -- & .022 & -- & - & -760 & - \\
\hline & 2.7 & B & -- & .021 & -- & -- & -830 & - \\
\hline & 3.4 & B & -- & .024 & - & -- & $-1,100$ & - \\
\hline & 4.0 & B & - & .025 & -- & -- & -840 & -- \\
\hline & 4.6 & B & -- & .023 & - & -- & -890 & - \\
\hline & 5.2 & B & -- & .032 & - & -- & -520 & - \\
\hline & 5.8 & B & -- & .032 & - & -- & -560 & - \\
\hline & 6.4 & B & -- & .031 & -- & -- & -650 & - \\
\hline & 7.0 & B & -. & .034 & -- & -- & -670 & -- \\
\hline & 7.6 & B & -- & .038 & - & -. & -610 & - \\
\hline & 8.2 & B & -- & .045 & -- & -. & -330 & - \\
\hline & 8.8 & B & -. & .039 & - & -- & -490 & - \\
\hline & 9.4 & B & -- & .039 & -- & -- & -620 & - \\
\hline & 10.1 & B & -- & .045 & -- & - & -560 & -. \\
\hline & 10.7 & B & -- & .041 & -- & -- & -560 & - \\
\hline & 11.3 & B & -- & .038 & -- & -- & -530 & -- \\
\hline & 11.9 & B & -- & .039 & -- & -- & -700 & - \\
\hline & 12.5 & B & -- & .044 & - & -- & -600 & - \\
\hline & 13.1 & B & -- & .037 & - & -- & -720 & -- \\
\hline & 13.7 & B & - & .034 & - & - & -920 & -- \\
\hline & 14.3 & B & -- & .043 & - & -- & -570 & - \\
\hline & 14.9 & B & -- & .043 & -- & -- & -560 & - \\
\hline
\end{tabular}


Table 4. Results of laboratory analyses of hydrologic characteristics of drill cuttings from neutron-access boreho'?s--Continued

\begin{tabular}{|c|c|c|c|c|c|c|c|c|}
\hline \multirow{2}{*}{$\begin{array}{l}\text { Neutron- } \\
\text { access } \\
\text { borehole } \\
\text { number }\end{array}$} & \multirow{2}{*}{$\begin{array}{l}\text { Depth } \\
\text { (meters) }\end{array}$} & \multirow{2}{*}{$\begin{array}{l}\text { Rock } \\
\text { type }\end{array}$} & \multicolumn{3}{|c|}{$\begin{array}{l}\text { Gravimetrlc water content } \\
\text { (grams per gram) }\end{array}$} & \multicolumn{3}{|c|}{$\begin{array}{l}\text { Water potentlal } \\
\text { (kllopascals) }\end{array}$} \\
\hline & & & Composite & Coarse & Fine & Composite & Coarse & Fine \\
\hline USW & 0.9 & B & -- & 0.038 & -- & -- & $-2,900$ & -- \\
\hline \multirow[t]{23}{*}{ UZ-N66 } & 1.5 & B & -- & .032 & -- & -- & $-3,300$ & - \\
\hline & 2.1 & B & -- & .035 & - & -- & $-4,000$ & - \\
\hline & 2.7 & B & -- & .034 & - & -- & $-1,400$ & - \\
\hline & 3.4 & B & -- & .028 & -- & -- & $-4,300$ & - \\
\hline & 4.0 & B & -- & .029 & -- &.- & $-3,700$ & - \\
\hline & 4.5 & B & -- & .029 & -- & -. & $-1,900$ & -- \\
\hline & 5.2 & B & -- & .030 & -- & - & $-2,000$ & -- \\
\hline & 5.8 & B & -- & .032 & -- & - & $-1,700$ & - \\
\hline & 6.4 & B & -- & .032 &.- & -- & $-2,200$ & -- \\
\hline & 7.0 & B & -- & .042 & -. & -- & -380 & -- \\
\hline & 7.6 & B & -. & .033 & -- &.- & -720 &.- \\
\hline & 8.2 & B & -- & .042 & -. & -- & -580 & -- \\
\hline & 8.8 & B & - & -- & -- & -- & -- & -- \\
\hline & 9.4 & B & - & .037 & - & - & -650 &.- \\
\hline & 10.1 & B & -- & .041 & - & -- & -550 & -- \\
\hline & 10.7 & B & -- & .040 & -- & -- & -540 & -. \\
\hline & 11.3 & B & -- & .041 & -- & -- & -550 & -- \\
\hline & 11.9 & B & -- & .041 & -- & -- & -450 & -- \\
\hline & 12.5 & B & -- & .044 & -- & -- & -430 & - \\
\hline & 13.1 & B & -- & .045 & -- & -- & -370 & - \\
\hline & 13.7 & B & -- & .045 & - & -- & -490 & - \\
\hline & 14.3 & B & -- & .039 & -. & -- & -550 & - \\
\hline & 14.9 & B & - & .041 & -- & -- & -500 & -- \\
\hline USW & .6 & A & 0.044 & - & -- & -- & -180 & - \\
\hline \multirow[t]{16}{*}{ UZ-N67 } & .6 & A & .041 & - & - & - & - & - \\
\hline & 1.2 & A & .043 & -- & - & - & -110 & - \\
\hline & 1.2 & A & .044 & -- & - & - & -- & -- \\
\hline & 1.8 & A & .042 & -- & -- & -- & -170 & - \\
\hline & 1.8 & A & .045 & -- & -- & -- & - & - \\
\hline & 2.4 & A & .026 & -- & -- & -. & $-1,400$ & - \\
\hline & 2.4 & A & .027 & -- & -- & -- & - & -- \\
\hline & 3.0 & A & .029 & - & -- & - & -190 & -- \\
\hline & 3.0 & A & .030 & - & -- & -- & - & -- \\
\hline & 3.7 & A & .036 & -- &.- & -- & -160 & -- \\
\hline & 3.7 & A & .038 & - & -- & -- & - & - \\
\hline & 4.3 & A & .038 & - & - & -- & -350 & -- \\
\hline & 4.3 & A & .039 & -- & -- & -- & -- & -- \\
\hline & 4.9 & A & .040 & - & -- & -- & -310 & -- \\
\hline & 4.9 & A & .041 & -- & -- & -. & - & -. \\
\hline & 5.5 & A & .053 & - & -- & -- & -400 & -- \\
\hline
\end{tabular}


Table 4. Results of laboratory analyses of hydrologic characteristics of drill cuttings from neutron-access boreholes--Ccntinued

\begin{tabular}{|c|c|c|c|c|c|c|c|c|}
\hline \multirow{2}{*}{$\begin{array}{l}\text { Neutron- } \\
\text { access } \\
\text { borehole } \\
\text { number }\end{array}$} & \multirow{2}{*}{$\begin{array}{l}\text { Depth } \\
\text { (meters) }\end{array}$} & \multirow{2}{*}{$\begin{array}{l}\text { Rock } \\
\text { type }\end{array}$} & \multicolumn{3}{|c|}{$\begin{array}{l}\text { Gravimetric water content } \\
\text { (grams per gram) }\end{array}$} & \multicolumn{3}{|c|}{$\begin{array}{l}\text { Water potential } \\
\text { (kilopascals) }\end{array}$} \\
\hline & & & Composite & Coarse & Fine & Composite & Coarse & Fine \\
\hline \multicolumn{9}{|c|}{ USW } \\
\hline \multicolumn{9}{|c|}{ UZ-N67--Continued } \\
\hline & 5.5 & $\mathbf{A}$ & 0.054 & -- & -- & -- & -- & -- \\
\hline & 6.1 & B & .028 & -- & -- & -- & -510 & - \\
\hline & 6.1 & B & .030 & -- & - & -- & -- & - \\
\hline & 6.7 & B & .014 & -- & - & -- & -630 & - \\
\hline & 6.7 & B & .015 & - & - & -- & - & - \\
\hline & 7.3 & B & .016 & - & - & -- & -750 & - \\
\hline & 7.3 & B & .016 & - & - & -- & - & - \\
\hline USW & 0.6 & A & .046 & - & -- & - & -390 & - \\
\hline \multirow{31}{*}{ UZ-N68 } & .6 & A & .045 & -- & - & - & -- & - \\
\hline & 1.2 & A & .059 & -- & -- & - & -- & - \\
\hline & 1.2 & A & .059 & - & - & -- & -- & - \\
\hline & 1.8 & A & .085 & -- & -- & -- & -200 & - \\
\hline & 1.8 & A & .084 & -- & - & - & -- & - \\
\hline & 2.4 & A & .069 & -- & - & -- & -- & - \\
\hline & 2.4 & A & .068 & - & - & .- & - & - \\
\hline & 3.0 & A & .061 & -- & - & -- & -110 & - \\
\hline & 3.0 & A & .059 & - & - & -. & -- & -- \\
\hline & 3.7 & A & .061 & -- & - & -- & -. & -- \\
\hline & 3.7 & A & .058 & -- & -- & - & - & - \\
\hline & 4.3 & A & .056 & -- & -- & - & -95 & -. \\
\hline & 4.9 & A & .047 & - & -- & -- & -- & - \\
\hline & 4.9 & A & .047 & -- & - & - & -- & - \\
\hline & 5.5 & A & .051 & -. & -. & -. & -57 & - \\
\hline & 5.5 & A & .053 & -- & - & -- & - & - \\
\hline & 6.1 & A & .048 & - & - & -. & - & - \\
\hline & 6.1 & A & .051 & -- & - & -- & - & - \\
\hline & 6.7 & A & .056 & - & - & -- & -190 & -720 \\
\hline & 6.7 & A & .051 & -- & -- & -- & - & -- \\
\hline & 7.3 & A & .050 & - & - & - & -- & -- \\
\hline & 7.3 & A & .050 & -- & - & - & -- & -- \\
\hline & 7.9 & A & .051 & -- & - & -- & -450 & - \\
\hline & 7.9 & A & .053 & -- & -- & - & - & -- \\
\hline & 8.5 & A & .045 & -- & - & -- & -- & -- \\
\hline & 8.5 & $A$ & .048 & - & - & -- & - & - \\
\hline & 9.1 & A & .057 & -- & -- & -- & -370 & -- \\
\hline & 9.1 & A & .053 & -- & - & -- & -- & - \\
\hline & 9.8 & A & .049 & -- & - & -- & - & -- \\
\hline & 9.8 & A & .051 & -- & - & -- & -- & - \\
\hline & 10.4 & A & .039 & -. & - & - & -330 & -- \\
\hline
\end{tabular}


Table 4. Results of laboratory analyses of hydrologic characteristics of drill cuttings from neutron-access borehcles--Continued

\begin{tabular}{|c|c|c|c|c|c|c|c|c|}
\hline \multirow{2}{*}{$\begin{array}{c}\text { Neutron- } \\
\text { access } \\
\text { borehole } \\
\text { number }\end{array}$} & \multirow{2}{*}{$\begin{array}{l}\text { Depth } \\
\text { (meters) }\end{array}$} & \multirow{2}{*}{$\begin{array}{l}\text { Rock } \\
\text { type }\end{array}$} & \multicolumn{3}{|c|}{$\begin{array}{l}\text { Gravimetric water content } \\
\text { (grams per gram) }\end{array}$} & \multicolumn{3}{|c|}{$\begin{array}{l}\text { Water potential } \\
\text { (kilopascals) }\end{array}$} \\
\hline & & & Composite & Coarse & Fine & Composite & Coarse & Fine \\
\hline \multicolumn{9}{|l|}{ USW } \\
\hline \multicolumn{9}{|c|}{ UZ-N68--Continued } \\
\hline & 10.4 & A & 0.038 & -- & -- & -- & - & - \\
\hline & 11.0 & A & .040 & -- & -- & $\cdots$ & - & - \\
\hline & 11.0 & A & .039 & -- & -- & -- & - & - \\
\hline & 11.6 & A & .045 & -- & -- & -- & -140 & - \\
\hline & 11.6 & A & .043 & - & - & - & - & - \\
\hline & 12.2 & A & .046 & -- & -- & -- & - & -- \\
\hline & 12.2 & A & .048 & - & - & - & -- & -- \\
\hline & 12.8 & A & .042 & - & -- & - & -440 & - \\
\hline & 12.8 & A & .047 & -- & -- & -- & - & -- \\
\hline & 13.4 & A & .038 & - & - & -- & -- & -- \\
\hline & 13.4 & A & .045 & - & -- & - & -- & -- \\
\hline & 14.0 & A & .039 & - & -- & -- & -140 & - \\
\hline & 14.0 & A & .039 & - & - & .- & - & -- \\
\hline & 14.6 & A & .077 & - & -- & -. & -- & - \\
\hline & 14.6 & A & .084 & -- & -- & - & - & -- \\
\hline & 15.2 & A & .081 & - & -- & -- & -350 & -- \\
\hline & 15.2 & A & .085 & - & - & -- & - & -- \\
\hline & 15.8 & B & .105 & - & -- & -- & - & -- \\
\hline & 15.8 & B & .121 & - & - & -- & - & - \\
\hline & 16.5 & B & .125 & - & -- & -- & -240 & -. \\
\hline & 16.5 & B & .121 & - & -- & -- & -- & -- \\
\hline USW & 0.6 & A & .059 & -- & -- & -- & -300 & - \\
\hline \multirow[t]{17}{*}{ UZ-N69 } & .6 & A & .058 & - & -- & -- & - & -- \\
\hline & 1.2 & A & .062 & -- & -- & - & - & - \\
\hline & 1.2 & $A$ & .061 & -. & -- & -- & - & -- \\
\hline & 1.8 & A & .065 & -- & -- & -- & -390 & -- \\
\hline & 1.8 & A & .064 & - & -- & -- & - & -. \\
\hline & 2.4 & A & .056 & -- & -- & -- & - & - \\
\hline & 2.4 & A & .058 & -- & -- & -- & - & - \\
\hline & 3.0 & A & .044 & - & -- & - & -710 & - \\
\hline & 3.0 & A & .042 & - & -- & -- & -- & -- \\
\hline & 3.7 & A & .045 & -- & -- & -- & -- & -- \\
\hline & 3.7 & A & .045 & - & -- & -- &.- & -. \\
\hline & 4.3 & A & .047 & - & -- & - & -340 & -- \\
\hline & 4.3 & A & .046 & -- & - & - & -- & -- \\
\hline & 4.9 & A & .044 & -- & -- & -- & -- & - \\
\hline & 4.9 & A & .044 & -- & -- & -- & -- & -- \\
\hline & 5.5 & A & .043 & -- & -- & -- & -340 & - \\
\hline & 5.5 & A & .042 & -- & -- & -- & -- & - \\
\hline
\end{tabular}


Table 4. Results of laboratory analyses of hydrologic characteristics of drill cuttings from neutron-access boreholes--Continued

\begin{tabular}{|c|c|c|c|c|c|c|c|c|}
\hline \multirow{2}{*}{$\begin{array}{l}\text { Neutron- } \\
\text { access } \\
\text { borehole } \\
\text { number }\end{array}$} & \multirow{2}{*}{$\begin{array}{l}\text { Depth } \\
\text { (meters) }\end{array}$} & \multirow{2}{*}{$\begin{array}{l}\text { Rock } \\
\text { type }\end{array}$} & \multicolumn{3}{|c|}{$\begin{array}{l}\text { Gravimetric water content } \\
\text { (grams per gram) }\end{array}$} & \multicolumn{3}{|c|}{$\begin{array}{l}\text { Water potential } \\
\text { (kllopascals) }\end{array}$} \\
\hline & & & Composite & Coarse & Fine & Composite & Coarse & Fina \\
\hline \multicolumn{9}{|l|}{ USW } \\
\hline \multicolumn{9}{|c|}{ UZ-N69--Continued } \\
\hline & 6.1 & A & 0.038 & -- & - & -- & -- & -- \\
\hline & 6.1 & A & .037 & -- & -- & -- & -- & -- \\
\hline & 6.7 & A & .039 & - & -. & -- & -450 & -. \\
\hline & 6.7 & A & .039 & -- & -- & -- & -- & -. \\
\hline & 7.3 & A & .045 & -- & -- & -- & -- & -- \\
\hline & 7.3 & A & .044 & -- & - & -- & - & -- \\
\hline & 7.9 & A & .040 & - & - & - & -59 & - \\
\hline & 7.9 & A & .044 & -- & - & -- & -- & -- \\
\hline & 8.5 & B & .046 & - & -- & -- & -- & -- \\
\hline & 8.5 & B & .043 & -. & - & -- & -- & -. \\
\hline & 9.1 & B & .024 & -- & - & -- & -720 & -- \\
\hline & 9.1 & B & .026 & -- & -- & -- & -- & -- \\
\hline & 9.8 & B & .021 & - & - & - & -- & - \\
\hline & 9.8 & B & .023 & -- & -- & -- & - & - \\
\hline USW & 0.5 & B & -- & 0.021 & -- & -- & $-6,600$ & - \\
\hline \multirow{24}{*}{ UZ-N70 } & .8 & B & -- & .025 & -- & -- & $-1,200$ & - \\
\hline & 1.1 & B & -- & .034 & -- & -- & $-1,400$ & - \\
\hline & 1.4 & B & -- & .034 & -- & -- & -760 & - \\
\hline & 1.7 & B & -- & .074 & -- & -- & -480 & - \\
\hline & 2.0 & B & -- & .062 & -- &.- & -370 & - \\
\hline & 2.3 & B & -- & .029 & -- & -- & -630 & - \\
\hline & 2.6 & B & -- & .050 & -- & -- & -550 & - \\
\hline & 2.9 & B & -- & .038 & - & -- & -680 & - \\
\hline & 3.2 & B & -- & .057 & -- & -- & -590 & - \\
\hline & 3.5 & B & - & .056 & -- & -- & -510 & - \\
\hline & 3.8 & B & -- & .036 & -- & - & -650 & - \\
\hline & 4.1 & B & - & .043 & -- & -- & -640 & - \\
\hline & 4.4 & B & -- & .044 & -- & -- & -830 & -- \\
\hline & 4.7 & B & -- & .053 & -- & -- & -710 & -- \\
\hline & 5.0 & B & -- & .051 & -- & -- & -660 & -- \\
\hline & 5.5 & B & -- & .030 & - & -- & -980 & - \\
\hline & 5.9 & B & -- & .034 & -- & - & -890 & - \\
\hline & 6.2 & B & -- & .036 & -- & -- & -610 & -- \\
\hline & 6.6 & B & -- & .039 & -- & -- & -970 & - \\
\hline & 7.0 & B & -- & .027 & -- & -- & $-1,300$ & - \\
\hline & 7.5 & B & -- & .035 & -- & -- & -880 & - \\
\hline & 7.8 & B & -- & .039 & -- & -- & -660 & - \\
\hline & 8.1 & B & -. & .037 & -- & -- & -740 & - \\
\hline & 8.5 & B & -- & .024 & -- & -- & $-4,000$ & -. \\
\hline
\end{tabular}


Table 4. Results of laboratory analyses of hydrologic characteristics of drill cuttings from neutron-access boreholes--Continued

\begin{tabular}{|c|c|c|c|c|c|c|c|c|}
\hline \multirow{2}{*}{$\begin{array}{l}\text { Neutron- } \\
\text { access } \\
\text { borehole } \\
\text { number }\end{array}$} & \multirow{2}{*}{$\begin{array}{l}\text { Depth } \\
\text { (meters) }\end{array}$} & \multirow{2}{*}{$\begin{array}{l}\text { Rock } \\
\text { type }\end{array}$} & \multicolumn{3}{|c|}{$\begin{array}{l}\text { Gravimetric water content } \\
\text { (grams per gram) }\end{array}$} & \multicolumn{3}{|c|}{$\begin{array}{l}\text { Water potential } \\
\text { (kilopascals) }\end{array}$} \\
\hline & & & Composite & Coarse & Fine & Composite & Coarse & Fine \\
\hline \multicolumn{9}{|l|}{ USW } \\
\hline \multicolumn{9}{|c|}{ UZ-N70--Continued } \\
\hline & 9.0 & B & -- & 0.037 & -- & -- & -720 & -- \\
\hline & 9.3 & B & -- & .031 & - & -- & -790 & - \\
\hline & 9.6 & B & -- & .027 & -- & - & $-1,900$ & -- \\
\hline & 10.1 & B & -- & .034 & -- & -- & -910 & - \\
\hline & 10.5 & B & -- & .044 & -- & - & -570 & -- \\
\hline USW & 0.9 & B & -- & .030 & -- & -- & -760 & -- \\
\hline \multirow[t]{13}{*}{ UZ-N72 } & 1.5 & B & -- & .035 & -- &.- & -620 & -- \\
\hline & 2.1 & B & - & .033 & - & -- & -530 & - \\
\hline & 2.7 & B & - & .031 & -- & -. & -570 & - \\
\hline & 3.4 & B & - & .025 & -- & -- & -680 & -- \\
\hline & 4.0 & B & -- & .030 & -- & -- & -500 &.- \\
\hline & 4.6 & B & -- & .037 & -- & -. & -340 & - \\
\hline & 5.2 & B & -- & .036 & -- & -. & -500 & - \\
\hline & 5.8 & B & -. & .037 & -- & -. & -550 & -- \\
\hline & 6.4 & B & -- & .042 & -- & -. & -450 & - \\
\hline & 7.0 & B & -- & .031 & -- & -. & -640 & - \\
\hline & 7.6 & B & -- & .036 & -- & -. & -500 & - \\
\hline & 8.2 & B & -- & .041 & -- & -- & -440 & - \\
\hline & 8.8 & B & -- & .045 & -- & -- & -380 & -- \\
\hline USW & .3 & B & -- & .024 & -- & -- & $-2,000$ & - \\
\hline \multirow[t]{14}{*}{ UZ-N73 } & .9 & B & -- & .022 & -. & -- & $-1,500$ & -- \\
\hline & 1.5 & B & -- & .026 & -- & -- & $-1,100$ & -- \\
\hline & 2.1 & B & -- & .019 & -- & -- & $-3,400$ & -- \\
\hline & 2.7 & B & -- & .018 & -- & -- & $-2,200$ & - \\
\hline & 3.4 & B & -- & .024 & -- & -- & $-1,200$ & - \\
\hline & 4.0 & B & -- & .035 & -- & -- & -830 & -- \\
\hline & 4.6 & B & - & .036 & -- & -- & -380 & -- \\
\hline & 5.2 & B & -- & .044 & -- & -- & -390 & -- \\
\hline & 5.8 & B & -- & .041 & -- & -. & -450 & - \\
\hline & 6.4 & B & -- & .045 & -- & -- & -490 & - \\
\hline & 7.0 & B & - & .065 & -- & -- & -460 & -- \\
\hline & 7.6 & B & -- & .055 & -- & -- & -440 & - \\
\hline & 8.2 & B & -- & .062 & -- & -- & -400 & - \\
\hline & 8.8 & B & -- & .054 & -- & -. & -410 & - \\
\hline
\end{tabular}


Table 4. Results of laboratory analyses of hydrologic characteristics of drill cuttings from neutron-access boreholes--Continued

\begin{tabular}{|c|c|c|c|c|c|c|c|c|}
\hline \multirow{2}{*}{$\begin{array}{l}\text { Neutron- } \\
\text { access } \\
\text { borehole } \\
\text { number }\end{array}$} & \multirow{2}{*}{$\begin{array}{c}\text { Depth } \\
\text { (meters) }\end{array}$} & \multirow{2}{*}{$\begin{array}{l}\text { Rock } \\
\text { type }\end{array}$} & \multicolumn{3}{|c|}{$\begin{array}{l}\text { Gravimetric water content } \\
\text { (grams per gram) }\end{array}$} & \multicolumn{3}{|c|}{$\begin{array}{l}\text { Water potential } \\
\text { (kllopascals) }\end{array}$} \\
\hline & & & Composite & Coarse & Fine & Composite & Coarse & Fing \\
\hline USW & 0.3 & B & $\cdots$ & 0.313 & - & -- & -700 & $\cdots$ \\
\hline \multirow[t]{22}{*}{ UZ-N74 } & .8 & B & - & .064 & - & - & -630 & - \\
\hline & 1.1 & B & - & .064 & -- & -- & -670 & - \\
\hline & 1.4 & B & -- & .050 & - & -. & -670 & -- \\
\hline & 1.8 & B & - & .038 & - & -- & -770 & -- \\
\hline & 2.3 & B & -- & .031 & - & -- & -650 & $-\cdot$ \\
\hline & 2.6 & B & - & .026 & - & -- & -960 & -- \\
\hline & 2.9 & B & -- & .026 & - & - & -950 & -- \\
\hline & 3.4 & B & - & .018 & - & -- & $-6,600$ & -. \\
\hline & 3.8 & B & -- & .010 & - & - & $-27,000$ & $\cdots$ \\
\hline & 4.1 & B & -- & .011 & - & -- & $-27,000$ & - \\
\hline & 4.4 & B & -- & .012 & -- & -- & $-28,000$ & - \\
\hline & 4.9 & B & -- & .008 & - & -- & $-31,000$ & - \\
\hline & 5.3 & B & -- & .008 & - & - & $-29,000$ & - \\
\hline & 5.6 & B & - & .010 & - & -- & $-7,100$ & - \\
\hline & 5.9 & B & -- & .013 & -- & -- & $-8,900$ & - \\
\hline & 6.4 & B & -- & .017 & - & -- & $-5,400$ & - \\
\hline & 6.9 & B & - & .017 & - & -- & $-4,000$ & - \\
\hline & 7.2 & B & -- & .020 & - &.- & $-5,100$ & - \\
\hline & 7.6 & B & -- & -- & - & - & -- & - \\
\hline & 8.2 & B & -- & .021 & - & -- & $-2,900$ & - \\
\hline & 9.4 & B & - & -- & - & - & -- & - \\
\hline & 10.5 & B & -- & .020 & - & $-\cdot$ & $-4,500$ & - \\
\hline USW & .3 & B & -- & .031 & -- & -. & $-1,400$ & - \\
\hline \multirow[t]{17}{*}{ UZ-N75 } & .8 & B & -- & .033 & -- & - & $-1,500$ & - \\
\hline & 1.1 & B & - & .051 & - & -- & -890 & - \\
\hline & 1.4 & B & -- & .043 & -- & - & $-1,200$ & - \\
\hline & 1.7 & B & - & .049 & - & -- & $-1,200$ & - \\
\hline & 2.1 & B & - & .040 & -- & -- & $-1,300$ & -- \\
\hline & 2.6 & B & -. & .043 & - & -- & $-1,000$ & -- \\
\hline & 2.9 & B & -. & .062 & -- & -- & -720 & - \\
\hline & 3.4 & B & -- & .062 & -- & -- & -680 & -- \\
\hline & 3.8 & B & -- & .059 & - & -- & -650 & - \\
\hline & 4.1 & B & -- & .063 & - & -- & -630 & - \\
\hline & 4.4 & B & -- & .055 & - & -- & -700 & -- \\
\hline & 4.7 & B & -- & - & - & -- & -- & - \\
\hline & 5.2 & B & - & .054 & - & - & -600 & - \\
\hline & 5.6 & B & -- & .046 & - & -- & -930 & -- \\
\hline & 6.1 & B & -- & .056 & - & - & -740 & - \\
\hline & 6.7 & B & -- & .069 & -- & -- & -610 & -- \\
\hline & 7.3 & B & - & .072 & - & - & -530 & - \\
\hline
\end{tabular}


Table 4. Results of laboratory analyses of hydrologic characteristics of drill cuttings from neutron-access boreholes--Continued

\begin{tabular}{|c|c|c|c|c|c|c|c|c|}
\hline \multirow{2}{*}{$\begin{array}{c}\text { Neutron- } \\
\text { access } \\
\text { borehole } \\
\text { number }\end{array}$} & \multirow{2}{*}{$\begin{array}{l}\text { Depth } \\
\text { (meters) }\end{array}$} & \multirow{2}{*}{$\begin{array}{l}\text { Rock } \\
\text { type }\end{array}$} & \multicolumn{3}{|c|}{$\begin{array}{l}\text { Gravlmetrlc water content } \\
\text { (grams per gram) }\end{array}$} & \multicolumn{3}{|c|}{$\begin{array}{l}\text { Water potentlal } \\
\text { (kllopascals) }\end{array}$} \\
\hline & & & Composite & Coarse & Fine & Composite & Coarse & Fine \\
\hline \multicolumn{9}{|l|}{ USW } \\
\hline \multicolumn{9}{|c|}{ UZ-N75--Continued } \\
\hline & 7.8 & B & -- & 0.061 & - & -- & -600 & -- \\
\hline & 8.7 & B & -- & .049 & -- & - & -690 & - \\
\hline & 10.1 & B & - & .047 & -- & - & -860 & -- \\
\hline USW & 0.9 & B & - & .111 & -. &.- & -390 & -. \\
\hline \multirow[t]{18}{*}{ UZ-N76 } & 1.5 & B & -- & .106 & - & - & -300 & -- \\
\hline & 2.1 & B & -- & .106 & -- & -- & -340 & -- \\
\hline & 2.7 & B & - & .106 & -- & -- & -320 & -. \\
\hline & 3.4 & B & -- & .111 & -- &.- & -310 & - \\
\hline & 4.0 & B & -- & .094 & -- & -- & -260 & - \\
\hline & 4.6 & B & $\cdots$ & .091 & -- & -- & -290 & -. \\
\hline & 5.2 & B & -- & .140 & -- & -- & -270 & -- \\
\hline & 5.8 & B & -- & .125 & - & -- & -300 & - \\
\hline & 6.4 & B & - & .107 & - & -. & -310 & - \\
\hline & 7.0 & B & - & .102 & -. & -. & -280 & - \\
\hline & 7.6 & B & -- & .115 & -. & -. & -320 & -. \\
\hline & 8.2 & B & -. & .115 & -- & -. & -220 & - \\
\hline & 8.8 & B & -- & .117 & - & -. & -220 & - \\
\hline & 9.4 & B & -- & .087 & -- & -- & -350 & - \\
\hline & 10.1 & B & -- & .115 & - & - & -370 & - \\
\hline & 10.7 & B & .- & .119 & -. & -. & -390 & -- \\
\hline & 11.3 & B & -- & .064 & -. & -. & -300 & -- \\
\hline & 11.9 & B & -. & .065 & -. & .- & -370 & -- \\
\hline USW & 0.9 & A & -- & .046 & - & - & -490 & -- \\
\hline \multirow[t]{15}{*}{ UZ-N77 } & 1.5 & A & -- & .053 & -- & -. & -500 & -- \\
\hline & 2.1 & A & - & .052 & -. & - & -500 & - \\
\hline & 2.7 & A & -- & .061 & -. & -. & -450 & -- \\
\hline & 3.4 & A & - & .063 & -- & - & -490 & -- \\
\hline & 4.0 & A & -- & .101 & -- & - & -860 & -- \\
\hline & 4.6 & A & -- & .081 & -- & - & -440 & -- \\
\hline & 5.2 & A & -- & .076 & -- & - & -560 & - \\
\hline & 5.8 & A & -- & .070 & -- & -- & -710 & -- \\
\hline & 6.4 & A & -- & .050 & - & -- & $-1,100$ & -. \\
\hline & 7.0 & $\mathrm{~A}$ & -- & .082 & -- & - & $-13,000$ & -. \\
\hline & 7.6 & A & -- & .048 & -- & -- & $-14,000$ & - \\
\hline & 8.2 & A & -- & .061 & -- & -- & $-5,600$ & -- \\
\hline & 8.8 & A & -- & .055 & -- & -. & $-5,000$ & - \\
\hline & 9.4 & A & -. & .073 & -- & - & $-3,900$ & -- \\
\hline & 10.1 & A & - & .071 & -- & -- & $-2,500$ & -- \\
\hline
\end{tabular}


Table 4. Results of laboratory analyses of hydrologic characteristics of drill cuttings from neutron-access boreholes--Cc ntinued

\begin{tabular}{|c|c|c|c|c|c|c|c|c|}
\hline \multirow{2}{*}{$\begin{array}{c}\text { Neutron- } \\
\text { access } \\
\text { borehole } \\
\text { number }\end{array}$} & \multirow{2}{*}{$\begin{array}{l}\text { Depth } \\
\text { (meters) }\end{array}$} & \multirow{2}{*}{$\begin{array}{l}\text { Rock } \\
\text { type }\end{array}$} & \multicolumn{3}{|c|}{$\begin{array}{l}\text { Gravimetric water content } \\
\text { (grams per gram) }\end{array}$} & \multicolumn{3}{|c|}{$\begin{array}{l}\text { Water potential } \\
\text { (kllopascals) }\end{array}$} \\
\hline & & & Composite & Coarse & Fine & Composite & Coarse & Fine \\
\hline \multicolumn{9}{|l|}{ USW } \\
\hline \multicolumn{9}{|c|}{ UZ-N77-Continued } \\
\hline & 10.7 & A & -- & 0.052 & - & - & $-3,600$ & - \\
\hline & 11.3 & A & -- & .047 & - & - & $-3,700$ & - \\
\hline & 11.9 & B & - & .033 & - & -- & $-1,200$ & $\cdots$ \\
\hline & 12.5 & B & -- & .040 & - & - & -510 & $\cdots$ \\
\hline & 13.1 & B & $\cdots$ & .034 & -- & - & -700 & $\cdots$ \\
\hline & 13.7 & B & -- & .037 & - & -- & -670 & - \\
\hline & 14.3 & B & -- & .036 & - & -- & -700 & - \\
\hline & 14.9 & B & -- & .041 & - & - & -910 & - \\
\hline USW & 0.9 & B & - & .022 & - & - & $-5,500$ & $\cdots$ \\
\hline \multirow[t]{19}{*}{ UZ-N78 } & 1.5 & B & - & .019 & - & -- & $-5,000$ & - \\
\hline & 1.5 & B & - & -- & - & -- & $-5,200$ & - \\
\hline & 2.1 & B & $\cdots$ & .020 & -- & - & $-2,100$ & - \\
\hline & 2.1 & B & $\cdots$ & -- & - & $\cdots$ & $-2,300$ & - \\
\hline & 2.7 & B & - & .018 & - & - & $-5,900$ & - \\
\hline & 2.7 & B & -- & -- & - & - & $-6,300$ & - \\
\hline & 3.4 & B & $\cdots$ & .016 & - & - & $-11,000$ & - \\
\hline & 3.4 & B & -- & -- & - & -- & $-6,800$ & - \\
\hline & 4.0 & B & - & .018 & - & - & $-7,100$ & - \\
\hline & 4.6 & B & -- & .018 & -- & - & $-3,300$ & - \\
\hline & 4.6 & B & - & -- & - & $\cdots$ & $-5,600$ & - \\
\hline & 5.2 & B & -- & -- & - & - & $-9,500$ & - \\
\hline & 5.2 & B & $\cdots$ & .016 & - & $\cdots$ & $-8,500$ & - \\
\hline & 5.8 & B & -- & .022 & -- & -- & $-3,400$ & - \\
\hline & 6.4 & B & -- & .022 & - & - & $-1,700$ & -- \\
\hline & 7.0 & B & -- & .019 & - & -- & $-4,200$ & - \\
\hline & 7.6 & B & -- & .018 & - & - & $-5,900$ & - \\
\hline & 8.2 & B & - & .019 & - & - & $-6,900$ & - \\
\hline & 8.8 & B & -- & .032 & - & -- & $-1,000$ & - \\
\hline USW & .9 & B & -- & .054 & - & - & -460 & $\cdots$ \\
\hline \multirow[t]{9}{*}{ UZ-N79 } & 1.5 & B & -- & .032 & $\cdots$ & - & -740 & $\cdots$ \\
\hline & 2.1 & B & $-\cdot$ & .036 & - &.- & -640 & $\cdots$ \\
\hline & 2.7 & B & $\cdots$ & .034 & -- & - & -600 & - \\
\hline & 3.4 & B & -- & .036 & -- & - & -560 & -- \\
\hline & 4.0 & B & - & .046 & - & -- & -870 & - \\
\hline & 4.6 & B & - & .040 & - & $\cdots$ & $-1,300$ & - \\
\hline & 5.2 & B & - & .042 & - & - & -850 & -- \\
\hline & 5.8 & B & - & .039 & - & -- & -520 & -- \\
\hline & 6.4 & B & -- & .038 & - & -- & -650 & -- \\
\hline
\end{tabular}


Table 4. Results of laboratory analyses of hydrologic characteristics of drill cuttings from neutron-access borehcles--Continued

\begin{tabular}{|c|c|c|c|c|c|c|c|c|}
\hline \multirow{2}{*}{$\begin{array}{l}\text { Neutron- } \\
\text { access } \\
\text { borehoie } \\
\text { number }\end{array}$} & \multirow{2}{*}{$\begin{array}{l}\text { Depth } \\
\text { (meters) }\end{array}$} & \multirow{2}{*}{$\begin{array}{l}\text { Rock } \\
\text { type }\end{array}$} & \multicolumn{3}{|c|}{$\begin{array}{l}\text { Gravimetric water content } \\
\text { (grams per gram) }\end{array}$} & \multicolumn{3}{|c|}{$\begin{array}{l}\text { Water potential } \\
\text { (kilopascals) }\end{array}$} \\
\hline & & & Composite & Coarse & Fine & Composite & Coarse & Fine \\
\hline \multicolumn{9}{|l|}{ USW } \\
\hline \multicolumn{9}{|c|}{ UZ-N79--Continued } \\
\hline & 7.0 & B & - & 0.038 & - & -- & -800 & -- \\
\hline & 7.6 & B & -- & .037 & -- & -- & $-1,100$ & -- \\
\hline & 8.2 & B & - & .039 & -- & -- & -690 & -- \\
\hline & 8.8 & B & - & .038 & -- & - & -780 & - \\
\hline & 9.4 & B & -- & .038 & -- & - & $-1,700$ & - \\
\hline USW & 0.9 & B & -- & .029 & -- & - & $-1,700$ & - \\
\hline \multirow[t]{24}{*}{ UZ-N80 } & 1.5 & B & - & .027 & -- & - & $-1,400$ & -- \\
\hline & 2.1 & B & -- & .018 & -- & -- & $-4,500$ & - \\
\hline & 2.7 & B & -- & .019 & - & -- & $-3,700$ & - \\
\hline & 3.4 & B & -- & .015 & - & - & $-7,500$ & -- \\
\hline & 4.0 & B & -- & .022 & -- & -- & $-3,600$ & -- \\
\hline & 4.6 & B & -. & .022 & -- & -- & $-3,400$ & - \\
\hline & 5.2 & B & -- & .022 & -- & -- & $-3,700$ & - \\
\hline & 5.8 & B & -- & - & -- & -- & $-4,200$ & - \\
\hline & 6.4 & B & -. & .021 & -- & - & $-4,200$ & -- \\
\hline & 7.0 & B & -. & .026 & -. & - & $-2,200$ & -. \\
\hline & 7.6 & B & -- & .028 & -- & -- & $-2,600$ & -. \\
\hline & 8.2 & B & - & .024 & - & - & $-3,700$ & -. \\
\hline & 8.8 & B & -- & .025 & - & - & $-2,900$ & -- \\
\hline & 9.4 & B & -- & .031 & - & -- & $-2,500$ & -- \\
\hline & 10.1 & B & - & .030 & -- & -- & $-2,700$ & -- \\
\hline & 10.7 & B & - & .027 & -- & -- & $-3,000$ & -- \\
\hline & 11.3 & B & - & .028 & -- & -. & $-2,900$ & - \\
\hline & 11.9 & B & -- & .040 & - & - & $-1,700$ & - \\
\hline & 12.5 & B & - & .027 & - & -- & $-4,100$ & -. \\
\hline & 13.1 & B & -- & .026 & -- & -. & $-4,800$ & - \\
\hline & 13.7 & B & -- & .020 & - & -- & $-7,600$ & - \\
\hline & 14.3 & B & -- & .018 & -- & -- & $-5,500$ & -. \\
\hline & 14.9 & B & -- & .020 & - &.- & $-4,300$ & - \\
\hline & 15.5 & B & -- & .024 & - & - & $-3,500$ & - \\
\hline USW & .9 & A & -- & .030 & -- & - & -980 & -. \\
\hline \multirow{7}{*}{ UZ-N81 } & 1.5 & A & - & .027 & -- & - & -870 & -. \\
\hline & 2.1 & A & -- & .036 & - & -- & -840 & -- \\
\hline & 2.7 & B & - & .032 & -- & -- & $-4,600$ & -- \\
\hline & 3.4 & B & -. & .029 & -- & - & $-5,700$ & -- \\
\hline & 4.0 & B & $\cdots$ & .026 & -- & -- & $-10,000$ & -- \\
\hline & 4.6 & B & -- & .029 & -- & - & $-3,700$ & - \\
\hline & 5.2 & B & -- & .028 & -- & -- & $-2,000$ & -- \\
\hline
\end{tabular}


Table 4. Results of laboratory analyses of hydrologic characteristics of drill cuttings from neutron-access boreholes-Continued

\begin{tabular}{|c|c|c|c|c|c|c|c|c|}
\hline \multirow{2}{*}{$\begin{array}{l}\text { Neutron- } \\
\text { access } \\
\text { borehole } \\
\text { number }\end{array}$} & \multirow{2}{*}{$\begin{array}{l}\text { Depth } \\
\text { (meters) }\end{array}$} & \multirow{2}{*}{$\begin{array}{l}\text { Rock } \\
\text { type }\end{array}$} & \multicolumn{3}{|c|}{$\begin{array}{l}\text { Gravimetric water content } \\
\text { (grams per gram) }\end{array}$} & \multicolumn{3}{|c|}{$\begin{array}{l}\text { Water potential } \\
\text { (kliopascais) }\end{array}$} \\
\hline & & & Composite & Coarse & Fine & Composite & Coarse & Fina \\
\hline USW & & & & & 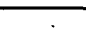 & & & \\
\hline \multicolumn{9}{|c|}{ UZ-N81--Continued } \\
\hline & 5.8 & B & - & 0.027 & - & -- & $-4,100$ & - \\
\hline & 6.4 & B & -- & .034 & -- & -- & $-1,800$ & - \\
\hline & 7.0 & B & - & .024 & - & -- & $-5,900$ & - \\
\hline & 7.6 & $\mathbf{B}$ & -- & .027 & - & -- & $-5,500$ & - \\
\hline & 8.2 & B & - & .029 & - & -- & $-4,300$ & - \\
\hline & 8.8 & B & -- & .033 & - & -- & $-1,200$ & - \\
\hline & 9.4 & B & -- & .029 & - & -- & $-2,300$ & - \\
\hline & 10.1 & B & -- & .029 & - & -- & $-3,000$ & - \\
\hline & 10.7 & B & -- & .029 & - & -- & $-2,700$ & - \\
\hline & 11.3 & B & -- & .030 & -- & - & $-2,700$ & -- \\
\hline & 11.9 & B & - & .029 & - & - & $-2,400$ & -- \\
\hline & 12.5 & B & -- & .029 & -- & - & $-4,100$ & -- \\
\hline & 13.1 & B & -- & .035 & -- & -- & -740 & -- \\
\hline & 13.7 & B & -- & .030 & - & - & $-1,900$ & -- \\
\hline & 14.3 & B & -- & .032 & - & -- & -980 & -- \\
\hline & 17.4 & B & - & .037 & - & -- & -570 & -- \\
\hline & 18.0 & B & -- & .032 & - & -- & -840 & -- \\
\hline & 18.6 & B & -- & .041 & - & -- & -460 & -- \\
\hline & 19.2 & B & -- & .039 & -- & -- & -580 & -- \\
\hline & 19.8 & B & -- & .035 & -- & -- & $-1,000$ & -- \\
\hline & 20.4 & B & -- & .036 & - & -- & -960 & -- \\
\hline & 21.0 & B & -- & .038 & $\cdots$ & -- & -610 & -- \\
\hline USW & 0.9 & A & - & .040 & -- & - & -600 & -- \\
\hline \multirow[t]{16}{*}{ UZ-N82 } & 1.5 & A & -- & .041 & - & - & -480 & -- \\
\hline & 2.1 & A & - & .043 & - & -- & -290 & 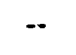 \\
\hline & 2.7 & A & -- & .053 & -- & - & -360 & -- \\
\hline & 3.4 & A & -- & .049 & - & -- & -330 & - \\
\hline & 4.0 & A & -- & .049 & - & -- & -360 & - \\
\hline & 4.6 & A & -- & .055 & - & - & -300 & - \\
\hline & 5.2 & A & -- & .068 & -- & -- & -340 & -- \\
\hline & 5.8 & A & -- & .067 & - & -- & -370 & - \\
\hline & 6.4 & A & -- & .069 & - & $\cdots$ & -380 &.- \\
\hline & 7.0 & A & -- & .046 & -- & -- & -540 &.- \\
\hline & 7.6 & B & $\cdots$ & .048 & $\cdots$ & - & -450 & - \\
\hline & 8.2 & B & -- & .044 & - & -- & -470 & - \\
\hline & 8.8 & B & -- & .043 & -- & -- & -520 & - \\
\hline & 9.4 & B & - & .048 & - & -- & -490 & - \\
\hline & 10.1 & B & -- & .051 & $\cdots$ & -- & -530 & $-\infty$ \\
\hline & 10.7 & B & -- & .056 & -- & -- & -460 & - \\
\hline
\end{tabular}


Table 4. Results of laboratory analyses of hydrologic characteristics of drill cuttings from neutron-access boreholes--Continued

\begin{tabular}{|c|c|c|c|c|c|c|c|c|}
\hline \multirow{2}{*}{$\begin{array}{c}\text { Neutron- } \\
\text { access } \\
\text { borehole } \\
\text { number }\end{array}$} & \multirow{2}{*}{$\begin{array}{l}\text { Depth } \\
\text { (meters) }\end{array}$} & \multirow{2}{*}{$\begin{array}{l}\text { Rock } \\
\text { type }\end{array}$} & \multicolumn{3}{|c|}{$\begin{array}{l}\text { Gravimetric water content } \\
\text { (grams per gram) }\end{array}$} & \multicolumn{3}{|c|}{$\begin{array}{l}\text { Water potential } \\
\text { (kilopascals) }\end{array}$} \\
\hline & & & Composite & Coarse & Fine & Composite & Coarse & Fine \\
\hline \multicolumn{9}{|l|}{ USW } \\
\hline \multicolumn{9}{|c|}{ UZ-N82-Continued } \\
\hline & 11.3 & B & - & 0.046 & -- & -- & -590 & - \\
\hline & 11.9 & B & - & .046 & - & - & -480 & - \\
\hline USW & 0.9 & B & -- & .034 & -- & - & $-4,000$ & -- \\
\hline \multirow[t]{33}{*}{ UZ-N83 } & 1.5 & B & - & .028 & - & -- & $-6,600$ & - \\
\hline & 2.1 & B & - & .032 & - & - & $-5,200$ & -- \\
\hline & 2.7 & B & - & .034 & - & - & $-4,600$ & -- \\
\hline & 3.4 & B & - & .031 & -- & - & $-7,600$ & -- \\
\hline & 4.0 & B & -- & .031 & -- & - & $-4,800$ & - \\
\hline & 4.6 & B & -- & .039 & - & - & $-3,400$ & -. \\
\hline & 5.2 & B & - & .033 & -- & -- & $-4,000$ & - \\
\hline & 5.8 & B & -- & .033 & -- & -- & $-4,800$ & - \\
\hline & 6.4 & B & -- & .032 & -. & -. & $-4,200$ & -. \\
\hline & 7.0 & B & .- & .034 & -- & -- & $-2,800$ & - \\
\hline & 7.6 & B & -- & .039 & -- & -- & -540 & - \\
\hline & 8.2 & B & - & .032 & -- & -- & $-2,200$ & - \\
\hline & 8.8 & B & -- & .035 & -- & -- & $-1,500$ & - \\
\hline & 9.4 & B & -- & .032 & -- & -- & $-2,200$ & -- \\
\hline & 10.1 & B & - & .040 & -. & .- & -310 & -. \\
\hline & 10.7 & B & - & .035 & -- & -- & -640 & - \\
\hline & 11.3 & B & -- & .045 & - & -- & -310 & -- \\
\hline & 11.9 & B & -- & .044 & -- & -- & $-1,100$ & - \\
\hline & 12.5 & B & -. & .035 & -- & -- & $-2,100$ & -- \\
\hline & 13.1 & B & - & .036 & -. & -- & $-1,000$ & -- \\
\hline & 13.7 & B & - & .040 & -- & -- & -440 & -- \\
\hline & 14.3 & B & -. & .037 & -- & -- & $-1,000$ & -- \\
\hline & 14.9 & B & -. & .040 & -- & -- & -840 & -- \\
\hline & 15.5 & B & -- & .035 & -- & -- & $-2,200$ & - \\
\hline & 16.2 & B & -- & .037 & -- & -- & $-2,500$ & -- \\
\hline & 16.8 & B & -. & .038 & -- & -- & $-1,400$ & -- \\
\hline & 17.4 & B & -- & .039 & - & -. & $-1,600$ & - \\
\hline & 18.0 & B & .. & .037 & -- & -- & $-2,900$ & -- \\
\hline & 18.6 & B & -- & .038 & -- & -- & $-1,600$ & -- \\
\hline & 19.2 & B & -- & .036 & -- & - & $-1,700$ & -- \\
\hline & 19.8 & B & - & .036 & -- & -- & -- & -- \\
\hline & 20.4 & B & -- & .037 & -- & -- & $-2,300$ & -- \\
\hline & 21.0 & B & -- & .036 & -- & -- & -980 & -- \\
\hline
\end{tabular}


Table 4. Results of laboratory analyses of hydrologic characteristics of drill cuttings from neutron-access boreholes--Continued

\begin{tabular}{|c|c|c|c|c|c|c|c|c|}
\hline \multirow{2}{*}{$\begin{array}{l}\text { Neutron- } \\
\text { access } \\
\text { borehoie } \\
\text { number }\end{array}$} & \multirow{2}{*}{$\begin{array}{l}\text { Depth } \\
\text { (meters) }\end{array}$} & \multirow{2}{*}{$\begin{array}{l}\text { Rock } \\
\text { type }\end{array}$} & \multicolumn{3}{|c|}{$\begin{array}{l}\text { Gravimetric water content } \\
\text { (grams per gram) }\end{array}$} & \multicolumn{3}{|c|}{$\begin{array}{l}\text { Water potentlal } \\
\text { (kilopascals) }\end{array}$} \\
\hline & & & Composite & Coarse & Fine & Composite & Coarse & Fine \\
\hline USW & 0.9 & A & -- & 0.032 & - & - & $-2,900$ & - \\
\hline \multirow[t]{21}{*}{ UZ-N84 } & 1.5 & A & -- & .021 & - & -- & $-7,600$ & - \\
\hline & 2.1 & A & -- & .022 & - & -- & $-7,500$ & - \\
\hline & 2.7 & A & -- & .039 & - & -- & $-7,800$ & - \\
\hline & 3.4 & A & -- & .020 & - & -- & $-9,200$ & - \\
\hline & 4.0 & A & - & .016 & - & - & $-12,000$ & - \\
\hline & 4.6 & A & -- & .016 & - & - & $-9,700$ & - \\
\hline & 5.2 & A & - & .018 & - & - & $-8,200$ & - \\
\hline & 5.8 & A & -- & .017 & - & - & $-12,000$ & - \\
\hline & 6.4 & A & -- & .014 & - & - & $-16,000$ & - \\
\hline & 7.0 & B & -- & .011 & - & - & $-15,000$ & - \\
\hline & 7.6 & B & -- & .011 & - & -- & $-11,000$ & - \\
\hline & 8.2 & B & -- & .009 & -- & -- & $-14,000$ & - \\
\hline & 8.8 & B & -- & .008 & -- & -- & $-14,000$ & -- \\
\hline & 9.6 & B & -- & .069 & -- & -- & -- & - \\
\hline & 10.1 & B & -- & .041 & -- & -- & -430 & - \\
\hline & 10.7 & B & -- & .034 & -- & - & -520 & - \\
\hline & 11.3 & B & -- & .046 & - & - & -450 & - \\
\hline & 11.9 & B & -- & .037 & - & - & -550 & -- \\
\hline & 12.5 & B & -- & .036 & - & - & -850 & - \\
\hline & 13.1 & B & -- & .018 & - & - & $-2,300$ & - \\
\hline & 13.6 & B & -- & .016 & -- & - & $-2,100$ & - \\
\hline UE-25 & .8 & A & -- & .025 & - & -- & $-39,000$ & -- \\
\hline \multirow[t]{18}{*}{ UZN \#85 } & 1.1 & A & -- & .022 & -- & -- & $-12,000$ & -- \\
\hline & 1.4 & A & -- & .023 & -- & -- & $-5,800$ & -- \\
\hline & 1.7 & A & -- & .027 & - & -- & $-4,600$ & -- \\
\hline & 2.0 & A & -- & .031 & -- & - & $-5,200$ & -- \\
\hline & 2.3 & A & -- & .017 & - & -- & $-13,000$ & - \\
\hline & 2.6 & A & -- & .039 & -- & -- & $-25,000$ & - \\
\hline & 2.9 & A & -- & .026 & -- & -- & $-12,000$ & - \\
\hline & 3.2 & A & -- & .021 & -- & -- & $-8,400$ & - \\
\hline & 3.5 & A & -- & .026 & -- & -- & $-3,600$ & - \\
\hline & 3.8 & A & -- & .021 & -- & -- & $-7,500$ & - \\
\hline & 4.1 & A & -- & .015 & -- & -- & $-15,000$ & - \\
\hline & 4.4 & A & -- & .011 & -- & -- & $-16,000$ & - \\
\hline & 4.7 & A & -- & .013 & -- & -- & $-15,000$ & - \\
\hline & 5.0 & A & - & .013 & -- & -- & $-10,000$ & - \\
\hline & 5.3 & A & -- & .019 & - & -- & $-13,000$ & - \\
\hline & 5.6 & A & -- & .015 & -- & -- & $-23,000$ & - \\
\hline & 5.9 & A & $\cdots$ & .018 & - & $\cdots$ & $-8,000$ & - \\
\hline & 6.2 & A & -- & .017 & - & -- & $-7,900$ & - \\
\hline
\end{tabular}


Table 4. Results of laboratory analyses of hydrologic characteristics of drill cuttings from neutron-access borehnles--Continued

\begin{tabular}{|c|c|c|c|c|c|c|c|c|}
\hline \multirow{2}{*}{$\begin{array}{c}\text { Neutron- } \\
\text { access } \\
\text { borehole } \\
\text { number }\end{array}$} & \multirow{2}{*}{$\begin{array}{c}\text { Depth } \\
\text { (meters) }\end{array}$} & \multirow{2}{*}{$\begin{array}{l}\text { Rock } \\
\text { type }\end{array}$} & \multicolumn{3}{|c|}{$\begin{array}{l}\text { Gravimetric water content } \\
\text { (grams per gram) }\end{array}$} & \multicolumn{3}{|c|}{$\begin{array}{l}\text { Water potential } \\
\text { (kllopascals) }\end{array}$} \\
\hline & & & Composite & Coarse & Fine & Composite & Coarse & Fine \\
\hline \multicolumn{9}{|l|}{ UE-25 } \\
\hline \multicolumn{9}{|c|}{ UZN \#85--Continued } \\
\hline & 6.6 & A & -- & 0.014 & -- & -- & $-6,300$ & -- \\
\hline & 6.9 & $A$ & -- & .012 & -- & -- & $-11,000$ & - \\
\hline & 7.2 & A & - & .017 &.- & - & $-10,000$ & - \\
\hline & 7.5 & A & -. & .022 & -- & -- & $-12,000$ & -. \\
\hline & 7.8 & A & -- & .026 & -- & - & $-13,000$ & - \\
\hline & 8.1 & A & -- & .014 & -- & -- & $-11,000$ & - \\
\hline & 8.4 & A & - & .017 & -- & - & $-14,000$ & - \\
\hline & 8.7 & A & - & .015 & -- & - & $-24,000$ & -- \\
\hline & 9.0 & A & -- & .018 & -- & -- & $-12,000$ & -- \\
\hline & 9.3 & A & - & .019 & -- & - & $-8,600$ & -- \\
\hline & 9.6 & A & - & .017 & - & -- & $-6,800$ & -- \\
\hline & 9.9 & A & -. & .009 & -- & -- & $-45,000$ & - \\
\hline & 9.9 & A & - & -- & - & -. & $-33,000$ & -- \\
\hline & 10.2 & A & - & .021 & - & - & $-19,000$ & - \\
\hline & 10.2 & A & - & - & - & -. & $-16,000$ & - \\
\hline & 10.5 & A & - & .023 & -. & -- & $-14,000$ & -- \\
\hline & 10.5 & A & - & - & -- & - & $-15,000$ & -- \\
\hline & 10.8 & A & -. & .019 & - & -- & $-15,000$ & -- \\
\hline & 10.8 & A & - & - & - & -- & $-12,000$ & - \\
\hline & 11.1 & A & -. & .020 & - & -- & $-6,800$ & - \\
\hline & 11.4 & A & - & .018 & - & -- & $-20,000$ & - \\
\hline & 11.4 & A & - & - & -- & - & $-16,000$ & -- \\
\hline & 11.7 & A & - & .025 & -. & - & $-14,000$ & - \\
\hline & 12.0 & A & -. & .022 & - & - & $-8,000$ & -- \\
\hline & 12.3 & A & - & .027 & -- & - & $-7,100$ & - \\
\hline & 12.6 & A & -- & .018 & - & - & $-5,800$ & -. \\
\hline & 13.0 & A & -- & .019 & -. & -. & $-10,000$ & - \\
\hline & 13.3 & A & -- & .024 & - & - & $-7,000$ & -. \\
\hline & 13.6 & A & -- & .024 & -- & -- & $-4,700$ & -. \\
\hline & 13.9 & A & -- & .023 & -- & - & $-6,000$ & - \\
\hline & 14.2 & A & -- & .021 &.- & -. & $-6,000$ & -. \\
\hline & 14.5 & A & - & .022 & - & - & $-18,000$ & - \\
\hline & 14.8 & A & -- & .023 &.- & -- & $-9,400$ & - \\
\hline & 15.1 & A & -- & .022 & -. & - & $-9,800$ & - \\
\hline & 15.4 & A & -- & .024 & -- & -- & $-5,000$ & -- \\
\hline & 15.7 & A & - & .021 & - & - & $-5,100$ & -- \\
\hline & 16.0 & A & - & .021 & -- & -- & $-14,000$ & -- \\
\hline & 16.3 & A & -- & .025 & - & -- & $-7,700$ & - \\
\hline & 16.6 & A & -. & .021 & -- & -- & $-10,000$ & - \\
\hline & 16.9 & A & -- & .023 & - & -- & $-6,100$ & - \\
\hline
\end{tabular}


Table 4. Results of laboratory analyses of hydrologic characteristics of drill cuttings from neutron-access boreholes--Continued

\begin{tabular}{|c|c|c|c|c|c|c|c|c|}
\hline \multirow{2}{*}{$\begin{array}{c}\text { Neutron- } \\
\text { access } \\
\text { borehole } \\
\text { number }\end{array}$} & \multirow{2}{*}{$\begin{array}{l}\text { Depth } \\
\text { (meters) }\end{array}$} & \multirow{2}{*}{$\begin{array}{l}\text { Rock } \\
\text { type }\end{array}$} & \multicolumn{3}{|c|}{$\begin{array}{l}\text { Gravimetrlc water content } \\
\text { (grams per gram) }\end{array}$} & \multicolumn{3}{|c|}{$\begin{array}{l}\text { Water potentlal } \\
\text { (kllopascals) }\end{array}$} \\
\hline & & & Composite & Coarse & Fine & Composite & Coarse & FIn \\
\hline \multicolumn{9}{|c|}{ UE-25 } \\
\hline \multicolumn{9}{|c|}{ UZN \#85--Continued } \\
\hline & 17.2 & $\mathbf{A}$ & -- & 0.028 & $\cdots$ & -- & $-3,900$ & -- \\
\hline & 17.5 & $\mathbf{A}$ & -- & .025 & -- & -- & $-15,000$ & -- \\
\hline & 17.8 & $\mathbf{A}$ & -- & .029 & -- & -- & $-7,100$ & - \\
\hline & 18.1 & A & -- & .036 & - & - & $-4,700$ & - \\
\hline & 18.4 & A & -- & .032 & -- & -- & $-2,600$ & - \\
\hline & 18.7 & A & -- & .030 & -- & -- & $-3,000$ & - \\
\hline & 19.0 & A & -- & .026 & -- & -- & $-6,700$ & - \\
\hline & 19.4 & $\mathbf{A}$ & - & .026 & -- & - & $-7,200$ & - \\
\hline & 19.7 & A & - & .025 & -- & -- & $-6,900$ & - \\
\hline & 20.0 & A & -- & .028 & -- & -- & $-4,600$ & - \\
\hline & 20.3 & A & -- & .028 & - & -- & $-5,700$ & - \\
\hline & 20.6 & $\mathbf{A}$ & -- & .017 & -. & -- & $-11,000$ & - \\
\hline & 20.9 & A & - & .018 & -- & -- & $-14,000$ & - \\
\hline & 21.2 & $\mathbf{A}$ & -- & .020 & - & -- & $-12,000$ & - \\
\hline & 21.5 & A & -- & .020 & - & -- & $-10,000$ & -- \\
\hline & 21.8 & $\mathbf{A}$ & -- & .027 & -- & -- & $-5,600$ & - \\
\hline & 22.1 & A & -- & .022 & - & -- & $-8,500$ & - \\
\hline & 22.4 & $\mathbf{A}$ & -. & .028 & - & -- & $-6,700$ & - \\
\hline & 22.7 & A & -- & .025 & -- & -- & $-4,600$ & - \\
\hline & 23.0 & A & -- & .032 & -- & - & $-4,500$ & - \\
\hline & 23.3 & $\mathbf{A}$ & -- & .028 & -- & -- & $-3,200$ & - \\
\hline & 23.6 & A & - & .035 & - & -- & $-8,000$ & - \\
\hline & 23.9 & $\mathbf{A}$ & -- & .027 & -- & -- & $-3,800$ & -- \\
\hline & 24.2 & $\mathbf{A}$ & -- & .026 & - & -- & $-4,200$ & - \\
\hline USW & 0.9 & B & -- & .027 & -- & -- & $-6,800$ & -- \\
\hline \multirow[t]{13}{*}{ UZ-N86 } & 1.5 & B & -- & .027 & - & -- & $-6,300$ & - \\
\hline & 2.1 & B & -- & .030 & -- & - & $-2,500$ & - \\
\hline & 2.7 & B & -- & .026 & -- & -- & $-2,500$ & - \\
\hline & 3.4 & B & - & .027 & - & -. & $-2,800$ & - \\
\hline & 4.0 & B & -- & .027 & -- & -. & $-3,300$ & - \\
\hline & 4.6 & B & - & .028 & -- & -- & $-3,600$ & - \\
\hline & 5.2 & B & -- & .028 & - & -- & $-3,800$ & - \\
\hline & 5.8 & B & - & .027 & - & -- & $-3,100$ & - \\
\hline & 6.4 & B & -- & .028 & -- & -- & $-3,200$ & - \\
\hline & 7.0 & B & -- & .028 & -- & -- & $-3,600$ & -- \\
\hline & 7.6 & B & -- & .029 & -- & - & $-3,200$ & - \\
\hline & 8.2 & B & - & .030 & -- & -. & $-2,900$ & -- \\
\hline & 8.8 & B & -- & .031 & -- & -- & $-1,600$ & -- \\
\hline
\end{tabular}


Table 4. Results of laboratory analyses of hydrologic characteristics of drill cuttings from neutron-access borehcles--Continued

\begin{tabular}{|c|c|c|c|c|c|c|c|c|}
\hline \multirow{2}{*}{$\begin{array}{l}\text { Neutron- } \\
\text { access } \\
\text { borehole } \\
\text { number }\end{array}$} & \multirow{2}{*}{$\begin{array}{l}\text { Depth } \\
\text { (meters) }\end{array}$} & \multirow{2}{*}{$\begin{array}{l}\text { Rock } \\
\text { type }\end{array}$} & \multicolumn{3}{|c|}{$\begin{array}{l}\text { Gravimetrlc water content } \\
\text { (grams per gram) }\end{array}$} & \multicolumn{3}{|c|}{$\begin{array}{l}\text { Water potentlal } \\
\text { (kliopascals) }\end{array}$} \\
\hline & & & Composite & Coarse & FIne & Composite & Coarse & Flne \\
\hline USW & 0.9 & $\mathrm{~A}$ & - & 0.049 & -- & -- & $-1,400$ & -- \\
\hline \multirow[t]{21}{*}{ UZ-N87 } & 1.5 & A & - & .035 & -- & -- & $-4,300$ & - \\
\hline & 2.1 & A & -- & .023 & -- & -- & $-5,600$ & -- \\
\hline & 2.7 & A & -- & .022 & -- & -- & $-4,700$ & - \\
\hline & 3.4 & A & -- & .024 & -- & -- & $-7,100$ & -- \\
\hline & 4.0 & A & -. & .023 & -- & -- & $-6,200$ & -- \\
\hline & 4.6 & A & -- & .023 & -- & -- & $-4,000$ & -- \\
\hline & 5.2 & A & - & .022 & - & - & $-4,600$ & -- \\
\hline & 5.8 & B & -- & .019 & -- & -- & $-8,700$ & -- \\
\hline & 6.4 & B & -- & .028 & -- & -- & $-1,700$ & - \\
\hline & 7.0 & B & -- & .012 & -- & -- & $-3,900$ & - \\
\hline & 7.6 & B & -- & .012 & - & -- & $-6,500$ & - \\
\hline & 8.2 & B & -- & .012 & -- & - & $-5,100$ & -- \\
\hline & 8.8 & B & -- & .010 & -- & -- & $-2,800$ & -- \\
\hline & 9.4 & B & -- & .011 & -- & -- & $-4,200$ & -- \\
\hline & 10.1 & B & -- & .010 & -- & -- & $-4,500$ & -- \\
\hline & 10.7 & B & - & .007 & - & -- & $-19,000$ & -- \\
\hline & 11.3 & B & - & .008 & -- & -- & $-31,000$ & -- \\
\hline & 11.9 & B & -. & .010 & -- & - & $-20,000$ & - \\
\hline & 12.5 & B & -- & .011 & -- & -- & $-14,000$ & -- \\
\hline & 13.1 & B & - & .008 & -- & -- & $-18,000$ & - \\
\hline & 13.6 & B & - & .009 & -- & -- & $-13,000$ & -- \\
\hline USW & .1 & A & - & .125 & -- & -- & - & -- \\
\hline \multirow[t]{16}{*}{ UZ-N88 } & .1 & A & -- & .166 & - & -. & -- & - \\
\hline & .4 & B & -- & .031 & -- & -- & $-2,200$ & -- \\
\hline & .9 & B & - & .021 & -- & .- & $-3,000$ & -- \\
\hline & 1.5 & B & -- & .015 & - & -- & $-5,300$ & -- \\
\hline & 2.1 & B & -. & .016 & - & -- & $-5,800$ & -- \\
\hline & 2.7 & B & -- & .014 & -- & -- & $-7,000$ & - \\
\hline & 3.4 & B & -- & .014 & -- & -- & $-8,700$ & -- \\
\hline & 4.0 & B & -- & .012 & -- & -- & $-11,000$ & - \\
\hline & 4.6 & B & -- & .012 & -- & - & $-17,000$ & -- \\
\hline & 5.2 & B & -- & .012 & - & -- & $-14,000$ & - \\
\hline & 5.8 & B & - & .014 & - & - & $-7,100$ & -- \\
\hline & 6.4 & B & -- & .017 & -- & -- & $-3,700$ & -- \\
\hline & 7.0 & B & -- & .017 & - & -- & $-3,200$ & - \\
\hline & 7.6 & B & -- & .016 & -- & -- & $-4,400$ & -- \\
\hline & 8.2 & B & -- & .017 & .. & -- & $-3,000$ & -- \\
\hline & 8.8 & B & -- & .016 & -- & - & $-2,600$ & - \\
\hline
\end{tabular}


Table 4. Results of laboratory analyses of hydrologic characteristics of drill cuttings from neutron-access boreholes--Continued

\begin{tabular}{|c|c|c|c|c|c|c|c|c|}
\hline \multirow{2}{*}{$\begin{array}{c}\text { Neutron- } \\
\text { access } \\
\text { borehole } \\
\text { number }\end{array}$} & \multirow{2}{*}{$\begin{array}{l}\text { Depth } \\
\text { (meters) }\end{array}$} & \multirow{2}{*}{$\begin{array}{l}\text { Rock } \\
\text { type }\end{array}$} & \multicolumn{3}{|c|}{$\begin{array}{l}\text { Gravimetric water content } \\
\text { (grams per gram) }\end{array}$} & \multicolumn{3}{|c|}{$\begin{array}{l}\text { Water potentiai } \\
\text { (kilopascais) }\end{array}$} \\
\hline & & & Composite & Coarse & Fine & Composite & Coarse & Fing \\
\hline USW & 0.9 & $\overline{\mathrm{A}}$ & - & 0.032 & - & -- & $-2,100$ & - \\
\hline \multirow[t]{20}{*}{ UZ-N89 } & 1.5 & A & -- & .044 & -- & -- & $-1,000$ & -- \\
\hline & 2.1 & A & -- & .053 & - & - & -590 & -- \\
\hline & 2.7 & A & -- & -- & - & - & -510 & - \\
\hline & 3.4 & A & -- & .056 & - & -- & -470 & - \\
\hline & 4.0 & A & -- & .053 & - & -- & -320 & - \\
\hline & 4.6 & A & -- & .058 & -- & -- & -460 & -- \\
\hline & 5.2 & A & -- & .062 & - & -- & -390 & -- \\
\hline & 5.8 & A & -- & .059 & - & -- & -400 & -- \\
\hline & 6.4 & A & -- & .067 & -- & -- & -290 & -- \\
\hline & 7.0 & A & - & .069 & - & - & -290 & -- \\
\hline & 7.6 & A & - & .059 & - & - & -430 & -- \\
\hline & 8.2 & A & -- & .053 & - & -- & -290 & -- \\
\hline & 8.8 & A & -- & .067 & - & - & -350 & -- \\
\hline & 9.4 & A & -- & .056 & -- & -- & -320 & - \\
\hline & 10.1 & B & -- & .060 & -- & -- & -290 & -- \\
\hline & 10.7 & B & -- & .067 & - & - & -350 & -- \\
\hline & 11.3 & B & -- & .061 & - & - & -360 & -- \\
\hline & 11.9 & B & -- & .062 & -- & -- & -290 & -- \\
\hline & 12.5 & B & -- & .063 & -- & -- & -310 & -- \\
\hline & 13.1 & B & -- & .074 & - & -- & -240 & -- \\
\hline USW & .9 & A & -- & .037 & - & -- & -750 & -- \\
\hline \multirow[t]{19}{*}{ UZ-N90 } & 1.5 & A & -- & .040 & -- & -- & -630 & -- \\
\hline & 2.1 & A & -- & .050 & - & -- & -260 & -- \\
\hline & 2.7 & A & -- & .052 & - & -- & -260 & - \\
\hline & 3.4 & A & -- & .057 & -- & -- & -270 & - \\
\hline & 4.0 & A & -- & .055 & -- & -- & -270 & - \\
\hline & 4.6 & A & -- & .062 & -- & -- & -560 & - \\
\hline & 5.2 & A & -- & -- & -- & -- & - & -- \\
\hline & 5.8 & A & -- & .069 & -- & - & -310 & -- \\
\hline & 6.4 & A & -- & .060 & - & -- & -210 & - \\
\hline & 7.0 & A & -- & .059 & - & -- & -210 & - \\
\hline & 7.6 & A & -- & .071 & - & -- & -570 & -- \\
\hline & 8.2 & A & -- & .052 & -- & -- & -260 & - \\
\hline & 8.8 & A & -- & .062 & - & -- & -510 & -. \\
\hline & 9.3 & A & -- & .063 & - & -- & -570 & - \\
\hline & 9.8 & A & -- & .066 & - & - & -500 & - \\
\hline & 10.5 & B & -- & .063 & -- & -- & -540 & - \\
\hline & 11.3 & B & - & .056 & -- & -- & -580 & - \\
\hline & 11.9 & B & -- & .060 & -- & -- & -210 & - \\
\hline & 12.5 & B & -- & .074 & -- & - & -510 & - \\
\hline
\end{tabular}


Table 4. Results of laboratory analyses of hydrologic characteristics of drill cuttings from neutron-access borehcles--Continued

\begin{tabular}{|c|c|c|c|c|c|c|c|c|}
\hline \multirow{2}{*}{$\begin{array}{c}\text { Neutron- } \\
\text { access } \\
\text { borehole } \\
\text { number }\end{array}$} & \multirow{2}{*}{$\begin{array}{c}\text { Depth } \\
\text { (meters) }\end{array}$} & \multirow{2}{*}{$\begin{array}{l}\text { Rock } \\
\text { type }\end{array}$} & \multicolumn{3}{|c|}{$\begin{array}{l}\text { Gravimetric water content } \\
\text { (grams per gram) }\end{array}$} & \multicolumn{3}{|c|}{$\begin{array}{l}\text { Water potentiai } \\
\text { (kliopascais) }\end{array}$} \\
\hline & & & Composite & Coarse & Fine & Composite & Coarse & Fine \\
\hline \multicolumn{9}{|c|}{ USW } \\
\hline \multicolumn{9}{|c|}{ UZ-N90--Continued } \\
\hline & 13.1 & B & - & 0.082 & - & -- & -540 & - \\
\hline & 13.7 & B & -- & .068 & - & -- & -520 & $\cdots$ \\
\hline UE-29 & 0.3 & A & - & .068 & - & -. & -540 & - \\
\hline \multirow[t]{36}{*}{ UZN \#91 } & .8 & A & -- & .081 & -. & - & -550 & - \\
\hline & 1.1 & A & - & .102 & -- & - & -490 & - \\
\hline & 1.4 & A & - & .102 & -- & -- & -420 & - \\
\hline & 1.8 & A & -- & .095 & - & -- & -640 & - \\
\hline & 2.3 & A & -- & .090 & - & - & -350 & - \\
\hline & 2.6 & A & -- & .081 & -. & - & -610 & -- \\
\hline & 2.9 & A & - & .082 & -- & - & -360 & - \\
\hline & 3.4 & A & -. & .080 & -- & -- & -320 & -. \\
\hline & 3.8 & A & -- & .079 & -. & - & -380 & -- \\
\hline & 4.1 & A & -. & .100 & -- & -. & -450 & -- \\
\hline & 4.4 & A & -- & .091 & .. & -. & -480 & - \\
\hline & 4.9 & A & - & .062 & -. & - & -480 & -- \\
\hline & 5.3 & A & - & .063 & - & - & -740 & -- \\
\hline & 5.6 & A & -- & .069 & - & -- & $-2,400$ & -- \\
\hline & 5.9 & A & - & .065 & - & -- & -650 & -- \\
\hline & 6.4 & A & -- & .104 & .. & .. & -960 & -- \\
\hline & 6.9 & A & -- & .082 & -. & -- & -770 & -. \\
\hline & 7.2 & A & -- & .077 & .. & -- & -410 & -. \\
\hline & 7.5 & A & -- & .071 & -- & -- & -550 & .. \\
\hline & 7.9 & A & -- & .065 & -- & -- & -670 & -- \\
\hline & 8.4 & A & -- & .062 & -- & -- & -430 & - \\
\hline & 8.7 & A & - & .057 & -- & .. & -710 & - \\
\hline & 9.0 & A & -- & .065 & -- & -- & -650 & - \\
\hline & 9.4 & A & .- & .079 & -- & -- & -410 & -- \\
\hline & 9.9 & A & -- & .075 & -- & -- & -510 & -- \\
\hline & 10.2 & A & -- & .078 & - & - & -420 & - \\
\hline & 10.5 & A & -- & .056 & -- & .. & -460 & -- \\
\hline & 10.8 & A & -- & .032 & -. & .. & $-4,100$ & -. \\
\hline & 11.1 & A & -- & .083 & -- & -- & -440 & -- \\
\hline & 11.4 & A & -- & .077 & -- & -. & -430 & - \\
\hline & 11.7 & A & -- & .078 & - & -- & -400 & - \\
\hline & 12.0 & A & -- & .078 & -- & - & -380 & - \\
\hline & 12.5 & A & -- & .084 & -- & -- & -970 & -- \\
\hline & 13.0 & A & -- & .073 & -- & -- & $-1,200$ & -- \\
\hline & 13.3 & A & -- & .069 & -- & - & -520 & -- \\
\hline & 13.6 & A & -- & .075 & -- & .. & -390 & .. \\
\hline
\end{tabular}


Table 4. Results of laboratory analyses of hydrologic characteristics of drill cuttings from neutron-access boreholes--Continued

\begin{tabular}{|c|c|c|c|c|c|c|c|c|}
\hline \multirow{2}{*}{$\begin{array}{c}\text { Neutron- } \\
\text { access } \\
\text { borehole } \\
\text { number }\end{array}$} & \multirow{2}{*}{$\begin{array}{c}\text { Depth } \\
\text { (meters) }\end{array}$} & \multirow{2}{*}{$\begin{array}{l}\text { Rock } \\
\text { type }\end{array}$} & \multicolumn{3}{|c|}{$\begin{array}{l}\text { Gravimetric water content } \\
\text { (grams per gram) }\end{array}$} & \multicolumn{3}{|c|}{$\begin{array}{l}\text { Water potential } \\
\text { (kilopascals) }\end{array}$} \\
\hline & & & Composite & Coarse & Fine & Composite & Coarse & Fine \\
\hline \multicolumn{9}{|c|}{ UE-29 } \\
\hline \multicolumn{9}{|c|}{ UZN \#91--Continued } \\
\hline & 13.9 & A & -- & 0.025 & -- & - & $-26,000$ & - \\
\hline & 14.2 & A & -- & .030 & -- & -- & $-8,300$ & -- \\
\hline & 14.5 & A & -- & .071 & -- & -- & -640 & -- \\
\hline & 14.8 & A & -- & .068 & -- & -. & -450 & -- \\
\hline & 15.1 & A & -- & .104 & -- & -- & -450 & -- \\
\hline & 15.5 & A & -- & .077 & - & -- & -430 & -- \\
\hline & 16.0 & A & -- & .083 & -- & -- & -600 & -- \\
\hline & 16.3 & A & -- & .080 & -- & -- & -840 & - \\
\hline & 16.6 & A & -- & .078 & -- & -- & -740 & - \\
\hline & 17.2 & A & -- & .093 & - & -- & -560 & -- \\
\hline & 17.8 & $A$ & -- & -- & -- & -- & -- & -- \\
\hline & 18.1 & A & -- & .088 & -- & -- & -540 & -- \\
\hline & 18.7 & A & - & .182 & -- & -- & -460 & -- \\
\hline & 19.4 & A & -- & .110 & - & -- & -450 & - \\
\hline & 20.0 & B & - & .081 & -- & -- & $-1,300$ & - \\
\hline & 20.7 & B & -- & -- & 0.077 & -- & $-14,000$ & - \\
\hline UE-25 & 0.3 & A & -- & .078 & -- & -- & -460 & - \\
\hline \multirow[t]{22}{*}{ UZN \#92 } & .8 & A & -- & .082 &.- & - & $-16,000$ & - \\
\hline & 1.1 & A & -- & .080 & -- & - & $-3,800$ & - \\
\hline & 1.4 & A & -- & .077 & - & -- & $-1,700$ & - \\
\hline & 1.7 & A & -- & .089 & -- & - & -- & - \\
\hline & 1.8 & A & -- & -- & -- & -- & $-13,000$ & - \\
\hline & 2.0 & A & -- & .089 & - & -- & -- & - \\
\hline & 2.3 & A & -- & .083 & -- & -- & -770 & - \\
\hline & 2.6 & A & -- & .084 & - & -- & -470 & - \\
\hline & 2.9 & A & -- & .071 & - & -- & -480 & - \\
\hline & 3.4 & A & -- & -- & - & -. & -570 & - \\
\hline & 3.8 & A & -- & .081 & -- & -- & -570 & -- \\
\hline & 4.1 & A & - & .071 & - & -- & $-27,000$ & -- \\
\hline & 4.4 & A & - & .051 & -- & -- & -440 & -- \\
\hline & 4.9 & A & -- & .058 & -- & - & $-3,300$ & - \\
\hline & 5.3 & A & -- & .077 & -- & -- & $-3,700$ & $\ldots$ \\
\hline & 5.6 & A & -- & .081 & - & - & -740 & - \\
\hline & 5.9 & A & -- & .063 & -- & -- & -580 & - \\
\hline & 6.4 & A & -- & .078 & - & -- & $-2,500$ & - \\
\hline & 6.9 & A & -- & .079 & -- & -- & -630 & -. \\
\hline & 7.2 & A & -- & .091 & -- & - & -630 & - \\
\hline & 7.5 & A & -- & - & -- & - & $-2,000$ & - \\
\hline & 7.9 & A & -. & .067 & -- & -- & $-4,200$ & - \\
\hline
\end{tabular}


Table 4. Results of laboratory analyses of hydrologic characteristics of drill cuttings from neutron-access boreholes--Continued

\begin{tabular}{|c|c|c|c|c|c|c|c|c|}
\hline \multirow{2}{*}{$\begin{array}{c}\text { Neutron- } \\
\text { access } \\
\text { borehole } \\
\text { number }\end{array}$} & \multirow{2}{*}{$\begin{array}{l}\text { Depth } \\
\text { (meters) }\end{array}$} & \multirow{2}{*}{$\begin{array}{l}\text { Rock } \\
\text { type }\end{array}$} & \multicolumn{3}{|c|}{$\begin{array}{l}\text { Gravimetric water content } \\
\text { (grams per gram) }\end{array}$} & \multicolumn{3}{|c|}{$\begin{array}{l}\text { Water potential } \\
\text { (kliopascals) }\end{array}$} \\
\hline & & & Composite & Coarse & Fine & Composite & Coarse & Fine \\
\hline \multicolumn{9}{|l|}{ UE-25 } \\
\hline \multicolumn{9}{|c|}{ UZN \#92--Continued } \\
\hline & 8.4 & A & -- & 0.065 & - & -- & $-1,700$ & - \\
\hline & 8.7 & A & -- & .063 & -- & -- & $-1,500$ & - \\
\hline & 9.0 & A & -- & .054 & -- & -- & $-2,200$ & - \\
\hline & 9.4 & A & -- & .079 & -- & -- & $-1,500$ & -- \\
\hline & 9.9 & A & - & .086 & -- & -- & -450 & -- \\
\hline & 10.2 & A & -- & .076 & -- & -- & -320 & -- \\
\hline & 10.5 & A & -- & .074 & -- & -- & -540 & - \\
\hline & 11.0 & A & - & .073 & -- & -- & -380 & -- \\
\hline & 11.4 & A & -- & .073 & -- & -- & -480 & - \\
\hline & 11.7 & A & -- & .064 & -- & -- & -860 & - \\
\hline & 12.0 & A & -- & .069 & -- & -- & $-7,200$ & -- \\
\hline & 12.5 & A & -- & .080 & -- & -- & -240 & -- \\
\hline & 13.0 & A & -- & .073 & -- & -- & -330 & -. \\
\hline & 13.3 & A & -- & .070 & -- & -- & -510 & -- \\
\hline & 13.6 & A & -- & .067 & -- & -- & -350 & - \\
\hline & 14.0 & A & -- & .074 & -- & -- & -650 & -- \\
\hline & 14.5 & A & -- & .060 & -- & -- & -630 & -- \\
\hline & 14.8 & A & -- & .064 & - & -- & -450 & -- \\
\hline & 15.1 & A & -. & .066 & - & -- & -400 & - \\
\hline & 15.5 & A & -- & .066 & -- & -- & -870 & - \\
\hline & 16.0 & A & -- & .065 & -- & -- & -400 & - \\
\hline & 16.3 & A & -- & .065 & -- & -- & -510 & - \\
\hline & 16.6 & A & -- & .068 & - & -- & -500 & - \\
\hline & 16.9 & A & -- & .075 & -- & -- & -450 & -- \\
\hline & 17.2 & A & -. & .066 & -. & -- & -370 & -. \\
\hline & 17.5 & A & - & .058 & -. & -. & -700 & -. \\
\hline & 17.8 & B & -- & .061 & -- & -- & -490 & -. \\
\hline & 18.1 & B & -- & .058 & - & - & -760 & - \\
\hline & 18.6 & B & - & - & 0.034 & -- & $-43,000$ & -- \\
\hline & 19.0 & B & - & .038 & -- & - & $-58,000$ & -- \\
\hline & 19.4 & B & - & .056 & -- & -- & $-35,000$ & -- \\
\hline & 19.7 & B & - & .041 & -- & -- & $-52,000$ & -- \\
\hline & 20.0 & B & -- & .026 & -- & - & $-60,000$ & -- \\
\hline & 20.3 & B & -- & .030 & -. & - & $-57,000$ & -. \\
\hline & 20.6 & B & -- & .023 & -- & -- & $-51,000$ & -- \\
\hline & 20.9 & B & - & .028 & -- & -- & $-58,000$ & -. \\
\hline & 21.2 & B & - & .027 & - & -- & $-55,000$ & -- \\
\hline & 21.6 & B & - & .022 & - & -- & $-59,000$ & -- \\
\hline & 22.1 & B & -- & .025 & -- & -- & $-64,000$ & -- \\
\hline & 22.4 & B & -- & .033 & -- & -- & $-52,000$ & -- \\
\hline
\end{tabular}


Table 4. Results of laboratory analyses of hydrologic characteristics of drill cuttings from neutron-access boreholes--Continued

\begin{tabular}{|c|c|c|c|c|c|c|c|c|}
\hline \multirow{2}{*}{$\begin{array}{c}\text { Neutron- } \\
\text { access } \\
\text { borehole } \\
\text { number }\end{array}$} & \multirow{2}{*}{$\begin{array}{l}\text { Depth } \\
\text { (meters) }\end{array}$} & \multirow{2}{*}{$\begin{array}{l}\text { Rock } \\
\text { type }\end{array}$} & \multicolumn{3}{|c|}{$\begin{array}{l}\text { Gravimetric water content } \\
\text { (grams per gram) }\end{array}$} & \multicolumn{3}{|c|}{$\begin{array}{l}\text { Water potential } \\
\text { (kilopascals) }\end{array}$} \\
\hline & & & Composite & Coarse & Fine & Composite & Coarse & Fin \\
\hline \multicolumn{9}{|l|}{ UE-25 } \\
\hline \multicolumn{9}{|c|}{ UZN \#92--Continued } \\
\hline & 22.7 & B & -- & 0.029 & -- & -- & $-38,000$ & - \\
\hline & 23.0 & B & -- & .026 & -- & -- & $-59,000$ & - \\
\hline & 23.3 & B & -- & .039 & - & - & $-38,000$ & - \\
\hline & 23.6 & B & -- & .026 & -- & -- & $-46,000$ & - \\
\hline & 23.9 & B & -- & .018 & - & - & $-45,000$ & - \\
\hline & 24.2 & B & -- & .016 & - & - & $-53,000$ & - \\
\hline & 24.7 & B & -- & .021 & - & -- & $-42,000$ & - \\
\hline & 25.1 & B & - & .020 & - & - & $-45,000$ & - \\
\hline & 25.5 & B & -- & .023 & - & - & $-46,000$ & - \\
\hline & 25.8 & B & - & .022 & - & - & $-50,000$ & -- \\
\hline & 26.1 & B & -- & .023 & - & - & $-48,000$ & - \\
\hline & 26.4 & B & -- & .026 & - & - & $-42,000$ & -- \\
\hline & 26.7 & B & -- & .025 & -- & -- & $-71,000$ & -- \\
\hline & 27.0 & B & -- & .023 & - & - & $-82,000$ & - \\
\hline & 27.3 & B & -- & .016 & - & -- & $-88,000$ & - \\
\hline & 27.7 & B & - & .024 & - & -- & $-85,000$ & - \\
\hline & 28.2 & B & -- & .031 & - & -- & $-82,000$ & - \\
\hline & 28.5 & B & - & .039 & - & - & 110,000 & - \\
\hline & 28.8 & B & - & .039 & - & -. & $-50,000$ & - \\
\hline & 29.1 & B & - & .024 & - & -. & $-62,000$ & - \\
\hline & 29.4 & B & -- & .037 & -- & -- & $-59,000$ & - \\
\hline & 29.7 & B & -- & .035 & -- & -- & $-57,000$ & - \\
\hline & 30.0 & B & -- &.- & - & - & $-57,000$ & - \\
\hline & 30.2 & B & -- & .028 & -- & - & - & - \\
\hline & 30.3 & B & - & -- & - & - & $-59,000$ & - \\
\hline & 30.8 & B & -- & .020 & - & -. & $-71,000$ & - \\
\hline & 31.2 & B & -- & .032 & -- & - & $-86,000$ & - \\
\hline & 31.5 & B & -- & .031 & - & - & $-72,000$ & - \\
\hline & 31.9 & B & -- & .047 & -- & 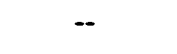 & $-75,000$ & - \\
\hline USW & 0.6 & B & 0.018 & -- & - & - & $-7,100$ & - \\
\hline \multirow[t]{9}{*}{ UZ-N93 } & 1.2 & B & -- & -- & - & - & -- & - \\
\hline & 1.8 & B & -- & -- & - & -- & -- & - \\
\hline & 2.4 & B & .015 & - & - & -- & $-25,000$ & - \\
\hline & 2.4 & B & .017 & -- & - & - & -- & -- \\
\hline & 3.0 & B & .018 & -- & - & -- & $-22,000$ & -- \\
\hline & 3.0 & B & .019 & -- & -- & -- & -- & - \\
\hline & 3.7 & B & .065 & -- & - & - & -- & - \\
\hline & 3.7 & B & .065 & -- & - & -- & -- & - \\
\hline & 4.3 & B & .055 & -- & - & -. & -540 & - \\
\hline
\end{tabular}


Table 4. Results of laboratory analyses of hydrologic characteristics of drill cuttings from neutron-access borehnles--Continued

\begin{tabular}{|c|c|c|c|c|c|c|c|c|}
\hline \multirow{2}{*}{$\begin{array}{c}\text { Neutron- } \\
\text { access } \\
\text { borehole } \\
\text { number }\end{array}$} & \multirow{2}{*}{$\begin{array}{l}\text { Depth } \\
\text { (meters) }\end{array}$} & \multirow{2}{*}{$\begin{array}{l}\text { Rock } \\
\text { type }\end{array}$} & \multicolumn{3}{|c|}{$\begin{array}{l}\text { Gravlmetrlc water content } \\
\text { (grams per gram) }\end{array}$} & \multicolumn{3}{|c|}{$\begin{array}{l}\text { Water potentlal } \\
\text { (kllopascals) }\end{array}$} \\
\hline & & & Composite & Coarse & Fine & Composite & Coarse & Fine \\
\hline \multicolumn{9}{|l|}{ USW } \\
\hline \multicolumn{9}{|c|}{ UZ-N93--Continued } \\
\hline & 4.3 & B & 0.055 & -- & - & - & - & - \\
\hline & 4.9 & B & .045 & -- & -- & - & - & -- \\
\hline & 4.9 & B & .047 & -- & -- & - & -- & -- \\
\hline & 5.5 & B & .037 & -- & -- & -- & -350 & -- \\
\hline & 5.5 & B & .036 & - & -- & - & - & - \\
\hline & 6.1 & B & .033 & - & -- & -- & -330 & -- \\
\hline & 6.1 & B & .032 & - & - & -- & - & -- \\
\hline & 6.7 & B & .031 & - & - & -- & - & - \\
\hline & 6.7 & B & .029 & - & - & -- & - & - \\
\hline & 7.3 & B & .031 & - & -- & - & -300 & - \\
\hline & 7.3 & B & .032 & - & -- & -- & - & - \\
\hline & 7.9 & B & .028 & - & - & -- & - & - \\
\hline & 7.9 & B & .028 & - & - & -- & - & - \\
\hline & 8.5 & B & .023 & -- & -- & -- & -270 & -- \\
\hline & 8.5 & B & .023 & - & -- & -- & - & -- \\
\hline & 9.1 & B & .020 & - & -- & -- & - &.- \\
\hline & 9.1 & B & .020 & - & -- & -- & -- & - \\
\hline & 9.8 & B & .029 & - & -. & -- & -610 & - \\
\hline & 9.8 & B & .028 & -. & -- & -- & - & -- \\
\hline & 10.4 & B & .030 & -- & -- & -- & - & -- \\
\hline & 10.4 & B & .031 & -- & -. & -- & -- & -- \\
\hline & 11.0 & B & .030 & -- & -- & -- & -710 & -- \\
\hline & 11.0 & B & .032 & -- & -- & -- & - & -- \\
\hline & 11.6 & B & .036 & -- & -. & -- & - & -- \\
\hline & 11.6 & B & .037 & - & -- & -- & - & -- \\
\hline & 12.2 & B & .044 & -- & -. & -- & -320 & -- \\
\hline & 12.2 & B & .044 & -- & - & -- & -- & -- \\
\hline USW & 0.6 & B & .062 & 0.061 & 0.064 & -- & -270 & -- \\
\hline \multirow[t]{11}{*}{ UZ-N94 } & .6 & B & .063 & - & -- & -- & - & - \\
\hline & 1.2 & B & .038 & .042 & .036 & -- & -260 & -- \\
\hline & 1.2 & B & .043 & - & -- & -- & - & -- \\
\hline & 1.8 & B & .039 & .040 & .036 & -. & -300 & -- \\
\hline & 1.8 & B & .038 & - & - & -- & - & - \\
\hline & 2.4 & B & .033 & .033 & .028 & -- & -240 & - \\
\hline & 2.4 & B & .031 & -- & .028 & -- & - & -- \\
\hline & 3.0 & B & .031 & .033 & .030 & -- & -330 & -- \\
\hline & 3.0 & B & .031 & .033 & -- & -- & - & -- \\
\hline & 3.7 & B & .028 & .032 & .028 & -- & -380 & -- \\
\hline & 3.7 & B & .030 & - & -- & -- & -. & -- \\
\hline
\end{tabular}


Table 4. Results of laboratory analyses of hydrologic characteristics of drill cuttings from neutron-access boreholes--Continued

\begin{tabular}{|c|c|c|c|c|c|c|c|c|}
\hline \multirow{2}{*}{$\begin{array}{c}\text { Neutron- } \\
\text { access } \\
\text { borehole } \\
\text { number }\end{array}$} & \multirow{2}{*}{$\begin{array}{l}\text { Depth } \\
\text { (meters) }\end{array}$} & \multirow{2}{*}{$\begin{array}{l}\text { Rock } \\
\text { type }\end{array}$} & \multicolumn{3}{|c|}{$\begin{array}{l}\text { Gravimetric water content } \\
\text { (grams per gram) }\end{array}$} & \multicolumn{3}{|c|}{$\begin{array}{l}\text { Water potentlal } \\
\text { (kllopascals) }\end{array}$} \\
\hline & & & Composite & Coarse & Fine & Composite & Coarse & Fine \\
\hline \multicolumn{9}{|c|}{ USW } \\
\hline \multicolumn{9}{|c|}{ UZ-N94--Continued } \\
\hline & 4.3 & B & 0.029 & 0.029 & 0.024 & - & -540 & - \\
\hline & 4.3 & B & -- & -- & .023 & -- & -- & - \\
\hline & 4.9 & B & .030 & .032 & .027 & - & -470 & - \\
\hline & 4.9 & B & .031 & -- & - & -- & -- & - \\
\hline & 5.5 & B & .029 & .031 & .027 & -- & -510 & - \\
\hline & 5.5 & B & .030 & -- & - & -- & - & - \\
\hline & 6.1 & B & .022 & .024 & .018 & -- & -490 & - \\
\hline & 6.1 & B & .022 & - & .018 & - & - & -- \\
\hline & 6.7 & B & .015 & .018 & .014 & - & -430 & -- \\
\hline & 6.7 & B & .015 & -- & - & - & -- & -- \\
\hline & 7.3 & B & .015 & .016 & .014 & -- & -440 & -- \\
\hline & 7.3 & B & .015 & - & -- & -- & - & -- \\
\hline & 7.9 & B & .019 & .020 & .018 & -- & -350 & - \\
\hline & 7.9 & B & .018 & -- & - & -- & - & -- \\
\hline & 8.5 & B & .020 & .021 & .019 & - & -400 & -- \\
\hline & 8.5 & B & .020 & -- & -- & -- & -- & -- \\
\hline USW & 0.6 & B & .084 & .077 & .091 & -- & -420 & - \\
\hline \multirow[t]{19}{*}{ UZ-N95 } & .6 & B & .083 & - & - & -- & - & - \\
\hline & 1.2 & B & .073 & .067 & .078 & -- & -490 & - \\
\hline & 1.2 & B & .072 & .071 & - & -- & - & - \\
\hline & 1.8 & B & .056 & .060 & .058 & - & -330 & $\ldots$ \\
\hline & 1.8 & B & .058 & -- & -- & -- & -- & - \\
\hline & 2.4 & B & .028 & .036 & .030 & -- & -530 & - \\
\hline & 2.4 & B & .037 & -- & .030 & -- & -- & - \\
\hline & 3.0 & B & .029 & - & .026 & -- & -410 & - \\
\hline & 3.0 & B & .029 & -- & -- & -- & -- & -- \\
\hline & 3.7 & B & .021 & .022 & .021 & -- & -670 & - \\
\hline & 3.7 & B & .021 & -- & -- & -- & -- & - \\
\hline & 4.3 & B & .022 & - & .022 & -- & $-1,500$ & - \\
\hline & 4.3 & B & .022 & -. & -- & -- & -- & - \\
\hline & 4.9 & B & .027 & .027 & .026 & -- & -440 & - \\
\hline & 4.9 & B & .026 & .027 & - & -. & -- & - \\
\hline & 5.5 & B & .023 & .023 & .018 & -- & -750 & - \\
\hline & 5.5 & B & .021 & -- & -- & -- & -- & - \\
\hline & 6.1 & B & .017 & -. & .014 & -- & -800 & - \\
\hline & 6.1 & B & .017 & -- & -- & -- & -- & -. \\
\hline
\end{tabular}


Table 4. Results of laboratory analyses of hydrologic characteristics of drill cuttings from neutron-access boreho'os--Continued

\begin{tabular}{|c|c|c|c|c|c|c|c|c|}
\hline \multirow{2}{*}{$\begin{array}{l}\text { Neutron- } \\
\text { access } \\
\text { borehole } \\
\text { number }\end{array}$} & \multirow{2}{*}{$\begin{array}{l}\text { Depth } \\
\text { (meters) }\end{array}$} & \multirow{2}{*}{$\begin{array}{l}\text { Rock } \\
\text { type }\end{array}$} & \multicolumn{3}{|c|}{$\begin{array}{l}\text { Gravimetric water content } \\
\text { (grams per gram) }\end{array}$} & \multicolumn{3}{|c|}{$\begin{array}{l}\text { Water potential } \\
\text { (kilopascals) }\end{array}$} \\
\hline & & & Composite & Coarse & Fine & Composite & Coarse & Fine \\
\hline USW & 0.6 & $\bar{A}$ & 0.063 & 0.051 & 0.079 & -- & -360 & - \\
\hline \multirow[t]{28}{*}{ UZ-N96 } & .6 & A & .058 & - & -- & -- & - & -- \\
\hline & 1.2 & B & .061 & .047 & .082 & -- & -340 & - \\
\hline & 1.2 & B & .057 & - & -- & - & - & -- \\
\hline & 1.8 & B & .050 & .045 & .060 & -- & -290 & -- \\
\hline & 1.8 & B & .049 & .045 & -- & - & - & -- \\
\hline & 2.4 & B & .049 & .038 & .057 & - & -410 & -- \\
\hline & 2.4 & B & .048 & -- & -- & -- & - & - \\
\hline & 3.0 & B & .048 & .035 & .052 & - & -370 & - \\
\hline & 3.0 & B & .048 & -. & -- & - & - & - \\
\hline & 3.7 & B & .038 & .038 & .040 & -- & -620 & - \\
\hline & 3.7 & B & .038 & -- & - & - & - & - \\
\hline & 4.3 & B & .031 & -- & -- & - & -370 & - \\
\hline & 4.9 & B & - & -- & .017 & - & $-2,800$ & -- \\
\hline & 5.5 & B & .019 & -- & - & -- & $-2,300$ & - \\
\hline & 6.1 & B & .024 &.- & - & -- & $-1,800$ & -- \\
\hline & 6.7 & B & .033 & .033 & .028 & -- & -610 & -- \\
\hline & 6.7 & B & .032 & .033 & -- & -- & - & -- \\
\hline & 7.3 & B & -- & -- & .017 & -- & $-2,300$ & -- \\
\hline & 7.9 & B & -- & -- & .010 & -- & $-9,900$ & - \\
\hline & 8.5 & B & .026 & .027 & .019 & -- & $-1,100$ & -- \\
\hline & 8.5 & B & .025 & - & - & -- & -- & -- \\
\hline & 9.1 & B & .030 & .032 & .023 & - & -490 & -- \\
\hline & 9.1 & B & .031 & .030 & - & -- & - & -- \\
\hline & 9.8 & B & .029 & .029 & .019 & - & $-2,000$ & -- \\
\hline & 9.8 & B & .028 & .029 & -- & - & - & -- \\
\hline & 10.4 & B & .021 & - & - & - & $-3,300$ & - \\
\hline & 10.7 & B & .043 & .043 & - & - & -370 & - \\
\hline & 10.7 & B & .044 & - & - & - & - & -- \\
\hline UE-25 & .3 & A & -- & .049 & - & -- & -910 & -- \\
\hline \multirow[t]{11}{*}{ UZN \#97 } & .8 & A & -- & .052 & -- & -- & -710 & -- \\
\hline & 1.1 & A & -- & .054 & - & -- & -750 & -- \\
\hline & 1.4 & A & -- & .050 & - & -- & -750 & -- \\
\hline & 1.7 & A & -- & .051 & -- & -- & -570 & - \\
\hline & 2.1 & A & -- & .046 & -- & -- & -940 & -- \\
\hline & 2.6 & A & -- & .041 & - & -- & $-1,100$ & -- \\
\hline & 2.9 & A & -- & .038 & - & -- & $-1,300$ & -- \\
\hline & 3.2 & A & -- & .040 & - & -- & $-1,300$ & -- \\
\hline & 3.7 & A & -- & .039 & -- & -- & $-1,100$ & -- \\
\hline & 4.1 & A & -- & .038 & -- & - & $-1,200$ & -- \\
\hline & 4.4 & A & -- & .036 & -. & -- & $-1,500$ & -- \\
\hline
\end{tabular}


Table 4. Results of laboratory analyses of hydrologic characteristics of drill cuttings from neutron-access boreholes--Continued

\begin{tabular}{|c|c|c|c|c|c|c|c|c|}
\hline \multirow{2}{*}{$\begin{array}{c}\text { Neutron- } \\
\text { access } \\
\text { borehole } \\
\text { number }\end{array}$} & \multirow{2}{*}{$\begin{array}{c}\text { Depth } \\
\text { (meters) }\end{array}$} & \multirow{2}{*}{$\begin{array}{l}\text { Rock } \\
\text { type }\end{array}$} & \multicolumn{3}{|c|}{$\begin{array}{l}\text { Gravimetric water content } \\
\text { (grams per gram) }\end{array}$} & \multicolumn{3}{|c|}{$\begin{array}{l}\text { Water potentlal } \\
\text { (kilopascals) }\end{array}$} \\
\hline & & & Composite & Coarse & Fine & Composite & Coarse & Firq \\
\hline \multicolumn{9}{|l|}{ UE-25 } \\
\hline \multicolumn{9}{|c|}{ UZN \#97-Continued } \\
\hline & 4.7 & $\mathbf{A}$ & - & 0.033 & - & -- & $-2,500$ & - \\
\hline & 5.2 & A & -- & .036 & - & -- & $-1,200$ & - \\
\hline & 5.6 & A & -- & .039 & - & -- & $-1,100$ & - \\
\hline & 5.8 & A & -- & .040 & - & - & -960 & - \\
\hline & 6.2 & A & 0.044 & -- & - & - & $-1,800$ & - \\
\hline & 6.7 & A & -- & .037 & -- & - & $-2,100$ & - \\
\hline & 7.2 & $\mathbf{A}$ & -- & .038 & - & -- & $-1,900$ & - \\
\hline & 7.5 & A & -- & .039 & - & - & $-1,300$ & - \\
\hline & 7.8 & A & -- & .031 & - & - & $-1,900$ & - \\
\hline & 8.1 & A & -- & .035 & - & - & $-1,300$ & - \\
\hline & 8.4 & A & -- & .032 & - & -- & $-1,200$ & - \\
\hline & 8.8 & A & -- & .031 & -- & - & $-1,600$ & - \\
\hline & 9.3 & A & -. & .032 & - & -- & $-1,800$ & $\ldots$ \\
\hline & 9.6 & $\mathbf{A}$ & -. & .035 & -- & -- & $-1,700$ & - \\
\hline & 9.9 & A & -- & .037 & -- & -- & $-1,500$ & $\cdots$ \\
\hline & 10.2 & A & -- & .038 & -- & - & $-1,500$ & $\cdots$ \\
\hline & 10.5 & A & -- & .037 & -- & -- & $-1,800$ & $\cdots$ \\
\hline & 11.0 & A & - & .036 & -- & - & $-1,700$ & - \\
\hline & 11.4 & A & -- & .038 & -- & - & $-1,300$ & - \\
\hline & 11.7 & A & -- & .039 & - & - & $-1,500$ & - \\
\hline & 12.0 & A & -- & .037 & - & - & $-1,500$ & - \\
\hline & 12.5 & A & - & .034 & -- & -- & $-1,700$ & - \\
\hline & 13.0 & A & -- & .039 & -- & -- & $-1,800$ & - \\
\hline & 13.3 & A & -- & .040 & - & - & $-1,500$ & - \\
\hline & 13.6 & $\mathbf{A}$ & - & .039 & - & -- & $-1,600$ & - \\
\hline & 14.0 & A & - & .040 & -- & - & $-1,400$ & - \\
\hline & 14.5 & A & - & .039 & -- & -- & $-1,600$ & - \\
\hline & 14.8 & A & -- & .044 & -- & -- & -990 & - \\
\hline & 15.1 & A & -- & .042 & -- & -- & $-1,300$ & - \\
\hline & 15.5 & A & - & .037 & - & -- & $-1,900$ & - \\
\hline & 16.0 & A & -- & .039 & - & - & $-1,400$ & - \\
\hline & 16.3 & A & -- & .038 & - & - & $-2,400$ & - \\
\hline & 16.6 & A & - & .035 & - & -- & $-1,900$ & - \\
\hline & 17.1 & A & - & .027 & - & -- & $-8,400$ & - \\
\hline & 17.5 & A & -- & .034 & - & -- & $-2,400$ & - \\
\hline & 17.8 & B & - & .034 & - & - & $-3,600$ & - \\
\hline & 18.1 & B & -- & .028 & -- & -- & $-6,900$ & - \\
\hline
\end{tabular}


Table 4. Results of laboratory analyses of hydrologic characteristics of drill cuttings from neutron-access boreholes--Continued

\begin{tabular}{|c|c|c|c|c|c|c|c|c|}
\hline \multirow{2}{*}{$\begin{array}{c}\text { Neutron- } \\
\text { access } \\
\text { borehole } \\
\text { number }\end{array}$} & \multirow{2}{*}{$\begin{array}{c}\text { Depth } \\
\text { (meters) }\end{array}$} & \multirow{2}{*}{$\begin{array}{l}\text { Rock } \\
\text { type }\end{array}$} & \multicolumn{3}{|c|}{$\begin{array}{l}\text { Gravimetrlc water content } \\
\text { (grams per gram) }\end{array}$} & \multicolumn{3}{|c|}{$\begin{array}{l}\text { Water potential } \\
\text { (kliopascals) }\end{array}$} \\
\hline & & & Composite & Coarse & Fine & Composite & Coarse & Fine \\
\hline USW & 0.3 & B & -- & 0.092 & -- & -- & -430 & - \\
\hline \multirow[t]{40}{*}{ UZ-N98 } & .8 & B & -- & .093 & - & -- & -600 & - \\
\hline & 1.1 & B & -- & .078 & - & - & -460 & - \\
\hline & 1.4 & B & -- & .071 & -- & -- & -950 & -- \\
\hline & 1.8 & B & - & .069 & -- & - & -470 & - \\
\hline & 2.3 & B & -- & .068 & - & -- & -740 & -- \\
\hline & 2.6 & B & - & .078 & -- & -- & -440 & -- \\
\hline & 2.9 & B & - & .073 & - & - & -610 & - \\
\hline & 3.4 & B & - & .075 & - & -. & -430 & - \\
\hline & 3.8 & B & -- & .072 & -- & - & -420 & -- \\
\hline & 4.1 & B & -- & .068 & $-\cdot$ & -- & -430 & - \\
\hline & 4.4 & B & - & .073 & -- & - & -490 & - \\
\hline & 4.9 & B & -- & .079 & -- & - & -400 & - \\
\hline & 5.3 & B & - & .083 & - & - & -600 & - \\
\hline & 5.6 & B & - & .085 & - & - & -600 & -- \\
\hline & 5.9 & B & -- & .091 & - & - & -470 & - \\
\hline & 6.4 & B & - & .093 & - & - & -590 & - \\
\hline & 6.9 & B & -- & .091 & - & - & -550 & - \\
\hline & 7.2 & B & -- & .081 & -- & - & -960 & - \\
\hline & 7.5 & B & - & .079 & -- & - & $-1,800$ & - \\
\hline & 7.8 & B & - & .110 & -- & - & $-2,000$ & - \\
\hline & 8.5 & B & - & .131 & - & - & $-2,500$ & - \\
\hline & 9.9 & B & - & .279 & -- & - & $-1,800$ & -- \\
\hline & 11.4 & B & -- & .285 & - & - & -450 & - \\
\hline & 13.0 & B & -- & .254 & - & -- & -490 & -- \\
\hline & 14.5 & B & -- & .305 & - & - & -580 & - \\
\hline & 15.5 & B & -- & - & 0.232 & -- & -710 & - \\
\hline & 16.2 & B & -- & .249 & -- & - & -750 & - \\
\hline & 16.6 & B & -- & .227 & -- & -- & -950 & - \\
\hline & 17.1 & B & -- & - & .164 & -- & $-18,000$ & - \\
\hline & 17.7 & B & - & .194 & -- & -- & $-4,500$ & -- \\
\hline & 18.1 & B & - & .176 & -- & -- & $-7,200$ & -- \\
\hline & 18.6 & B & -- & .177 & -- & - & $-2,900$ & -- \\
\hline & 19.2 & B & -- & - & .172 & - & $-5,900$ & - \\
\hline & 19.7 & B & - & - & .147 & - & $-5,600$ & -- \\
\hline & 20.1 & B & - & - & .162 & - & $-3,500$ & - \\
\hline & 20.7 & B & - & - & .342 & -- & -440 & - \\
\hline & 21.2 & B & - & .176 & -- & - & -900 & - \\
\hline & 21.6 & B & - & - & .152 & - & $-3,200$ & - \\
\hline & 22.3 & B & - & .184 & -- & -- & -530 & - \\
\hline & 22.7 & B & -- & .254 & -- & - & $-3,500$ & -- \\
\hline
\end{tabular}


Table 5. Results of laboratory analyses of hydrologic characteristics of core samples from selected neutron-access boreholes

$[--$, no data; $D$, drive core; $R$, rotary core $]$

\begin{tabular}{|c|c|c|c|c|c|c|c|c|}
\hline \multirow{2}{*}{$\begin{array}{l}\text { Neutron- } \\
\text { access } \\
\text { borehole } \\
\text { number }\end{array}$} & \multirow[t]{2}{*}{$\begin{array}{c}\text { Depth } \\
\text { Interval } \\
\text { (meters) }\end{array}$} & \multirow[t]{2}{*}{ Core type } & \multicolumn{3}{|c|}{$\begin{array}{l}\text { Gravimetric water content } \\
\text { (grams per gram) }\end{array}$} & \multicolumn{3}{|c|}{$\begin{array}{l}\text { Water potentlal } \\
\text { (kilopascals) }\end{array}$} \\
\hline & & & Composite & Coarse & Fine & Composite & Coarse & $F \cdot n$ \\
\hline UE-25 & $1.90-2.06$ & D & - & 0.056 & 0.096 & -280 & -300 & - \\
\hline \multirow[t]{13}{*}{ UZN \#1 } & $2.36-2.44$ & D & - & -- & -- & -240 & -- & - \\
\hline & $3.35-3.96$ & D & -- & .066 & .101 & -240 & -250 & -- \\
\hline & $4.95-5.11$ & D & -- & .091 & .149 & -92 & -320 & -330 \\
\hline & $5.18-5.26$ & D & -- & - & -- & -230 & - & - \\
\hline & $6.40-6.71$ & D & -- & .059 & .105 & -270 & -230 & -220 \\
\hline & $7.92-8.08$ & D & - & .074 & .165 & -350 & -310 & -170 \\
\hline & $8.15-8.23$ & D & - & - & -- & -250 & - & - \\
\hline & $8.53-8.60$ & $\mathbf{R}$ & 0.252 & - & -- & -300 & - & - \\
\hline & $8.76-8.92$ & $\mathbf{R}$ & .186 & - & -- & -370 & -- & - \\
\hline & $10.45-10.53$ & $\mathbf{R}$ & .202 & -- & -- & -370 & - & - \\
\hline & $12.05-12.09$ & $\mathbf{R}$ & - & - & -- & -210 & -- & - \\
\hline & $13.47-13.56$ & $\mathbf{R}$ & .174 & -- & -- & -250 & - & - \\
\hline & $13.96-14.08$ & $\mathbf{R}$ & .148 & -- & -- & -210 & -- & - \\
\hline UE-25 & $1.5-2.1$ & D & .044 & .035 & .067 & - & $-3,400$ & $-2,(00$ \\
\hline \multirow[t]{7}{*}{ UZN \#4 } & $1.5-2.1$ & D & - & - & .065 & - & $-3,200$ & - \\
\hline & $3.0-3.7$ & D & .026 & .023 & .040 & -- & $-2,500$ & $-1,500$ \\
\hline & $3.0-3.7$ & D & - & .023 & .041 & -- & $-2,700$ & - \\
\hline & $4.6-5.2$ & D & .042 & .033 & .076 & -- & -540 & -520 \\
\hline & $4.6-5.2$ & D & -- & .037 & .072 & -- & -460 & - \\
\hline & $6.1-6.7$ & D & .075 & .076 & .134 & -- & -86 & -2.50 \\
\hline & $6.1-6.7$ & D & .076 & -- & .135 & -- & -220 & -- \\
\hline UE-25 & $1.5-2.1$ & D & .081 & .067 & .092 & -- & -270 & $-\$ 50$ \\
\hline \multirow[t]{11}{*}{ UZN \#6 } & $1.5-2.1$ & D & .088 & .061 & .094 & -- & -- & - \\
\hline & $4.3-4.9$ & D & .086 & .065 & .105 & -- & -83 & -570 \\
\hline & $4.3-4.9$ & $\mathrm{D}$ & .081 & .066 & -- & - & -210 & - \\
\hline & $6.1-6.7$ & $\mathrm{D}$ & .056 & .084 & .125 & - & -600 & -150 \\
\hline & $6.1-6.7$ & $\mathrm{D}$ & .089 & .066 & .135 & -- & - & - \\
\hline & $7.6-8.2$ & $D$ & .067 & .068 & .102 & -- & -140 & -110 \\
\hline & $7.6-8.2$ & $D$ & .070 & .073 & .096 & -- & -- & -71 \\
\hline & $9.1-9.8$ & $\mathrm{D}$ & .070 & .056 & .106 & -- & -140 & -270 \\
\hline & $9.1-9.8$ & $\mathrm{D}$ & .075 & .061 & -- & -- & -240 & -120 \\
\hline & $10.7-11.3$ & $\mathrm{D}$ & .081 & .078 & .095 & - & -110 & -100 \\
\hline & $10.7-11.3$ & $\mathrm{D}$ & .076 & .072 & - & - & -- & - \\
\hline
\end{tabular}


Table 5. Results of laboratory analyses of hydrologic characteristics of core samples from selected neutron-access boreholes--Continued

\begin{tabular}{|c|c|c|c|c|c|c|c|c|}
\hline \multirow{2}{*}{$\begin{array}{l}\text { Neutron- } \\
\text { access } \\
\text { borehole } \\
\text { number }\end{array}$} & \multirow[t]{2}{*}{$\begin{array}{l}\text { Depth } \\
\text { Interval } \\
\text { (meters) }\end{array}$} & \multirow[t]{2}{*}{ Core type } & \multicolumn{3}{|c|}{$\begin{array}{l}\text { Gravimetric water content } \\
\text { (grams per gram) }\end{array}$} & \multicolumn{3}{|c|}{$\begin{array}{l}\text { Water potentlal } \\
\text { (kiiopascais) }\end{array}$} \\
\hline & & & Composite & Coarse & Fine & Composite & Coarse & Fine \\
\hline UE-25 & $1.5-2.1$ & D & 0.147 & -- & -- & -140 & -99 & -260 \\
\hline \multirow[t]{11}{*}{ UZN \#8 } & $1.5-2.1$ & D & .062 & -- & - & -- & -- & - \\
\hline & $3.0-3.7$ & D & .078 & -- & 0.127 & -200 & -130 & -180 \\
\hline & $3.0-3.7$ & D & -- & -- & -- & -200 & -- & -- \\
\hline & $4.6-5.2$ & D & .090 & -. & -- & -250 & -88 & -160 \\
\hline & $4.6-5.2$ & D & .067 & -- & -- & -250 & -- & - \\
\hline & $6.1-6.7$ & D & .076 & -- & - & -360 & -88 & -150 \\
\hline & $6.1-6.7$ & D & .078 & -- & -- & -270 & - & - \\
\hline & $7.6-8.2$ & D & .067 & - & -- & -210 & -82 & -150 \\
\hline & $9.1-9.8$ & D & .067 & 0.060 & .094 & -360 & -120 & -180 \\
\hline & $9.1-9.8$ & D & -. & -- & - & -330 & - & -170 \\
\hline & $10.7-11.3$ & D & .067 & .055 & .081 & -300 & -140 & -160 \\
\hline UE-25 & $0.0-0.12$ & $\mathbf{R}$ & .284 & -- & -- & -530 & - & -- \\
\hline \multirow[t]{27}{*}{ UZN \#10 } & $1.22-1.31$ & $\mathbf{R}$ & .183 & -- & -- & -700 & - & -. \\
\hline & $1.83-1.89$ & $\mathbf{R}$ & .178 & -- & -- & -500 & - & -- \\
\hline & $2.74-2.93$ & $\mathbf{R}$ & .169 & -- & -- & -580 & - & -- \\
\hline & $4.34-4.88$ & $\mathbf{R}$ & .190 & -- & -- & -- & - & -- \\
\hline & $4.50-4.57$ & $\mathbf{R}$ & .189 & -. & -. & -540 & - & -. \\
\hline & $4.88-4.94$ & $\mathbf{R}$ & .182 & -- & -- & -480 & -. & -- \\
\hline & $5.64-5.73$ & $\mathbf{R}$ & .184 & -- & -- & -540 & -- & -- \\
\hline & $6.04-6.13$ & $\mathbf{R}$ & .187 & -- & -- & -510 & -- & -- \\
\hline & $6.46-6.61$ & $\mathbf{R}$ & .182 & -. & -- & -420 & - & -- \\
\hline & $7.59-7.71$ & $\mathbf{R}$ & .166 & -- & - & -580 & -- & -- \\
\hline & $8.84-8.96$ & $\mathbf{R}$ & .161 & -- & -- & -650 & -- & -- \\
\hline & $10.09-10.18$ & $\mathbf{R}$ & .184 & -- & -- & -600 & -- & - \\
\hline & $10.97-11.13$ & $\mathbf{R}$ & .159 & -- & -- & -700 & -- & -- \\
\hline & $11.43-11.52$ & $\mathbf{R}$ & .162 & -- & -- & -530 & - & -- \\
\hline & $11.89-12.04$ & $\mathbf{R}$ & .132 & -- & -- & $-2,000$ & -- & -- \\
\hline & $12.31-12.44$ & $\mathbf{R}$ & .159 & -. & -- & -590 & -- & -- \\
\hline & $13.41-13.47$ & $\mathbf{R}$ & .133 & -- & -- & -970 & - & -- \\
\hline & $13.84-13.99$ & $\mathbf{R}$ & .148 & -- & -- & -790 & -- & - \\
\hline & $14.33-14.48$ & $\mathbf{R}$ & .154 & -- & -- & -770 & - & -- \\
\hline & $15.06-15.18$ & $\mathbf{R}$ & .148 & -- & -- & -740 & - & -- \\
\hline & $15.94-16.09$ & $\mathbf{R}$ & .176 & -- & -- & -740 & - & -- \\
\hline & $16.67-16.82$ & $\mathbf{R}$ & .161 & -- & -- & -720 & -- & - \\
\hline & $17.56-17.65$ & $\mathrm{R}$ & .187 & -- & -- & -610 & -- & -- \\
\hline & $18.07-18.17$ & $\mathrm{R}$ & .149 & -- & -- & -750 & -- & -- \\
\hline & $19.11-19.20$ & $\mathbf{R}$ & .163 & - & -- & -690 & -- & -- \\
\hline & $19.42-19.51$ & $\mathbf{R}$ & .140 & -- & -- & -610 & -- & -- \\
\hline & $19.69-19.81$ & $\mathrm{R}$ & .119 & -- & -- & -530 & -- & -- \\
\hline
\end{tabular}


Table 5. Results of laboratory analyses of hydrologic characteristics of core samples from selected neutron-access boreholes--Continued

\begin{tabular}{|c|c|c|c|c|c|c|c|c|}
\hline \multirow{2}{*}{$\begin{array}{c}\text { Neutron- } \\
\text { access } \\
\text { borehole } \\
\text { number }\end{array}$} & \multirow[t]{2}{*}{$\begin{array}{l}\text { Depth } \\
\text { interval } \\
\text { (meters) }\end{array}$} & \multirow[t]{2}{*}{ Core type } & \multicolumn{3}{|c|}{$\begin{array}{l}\text { Gravimetric water content } \\
\text { (grams per gram) }\end{array}$} & \multicolumn{3}{|c|}{$\begin{array}{l}\text { Water potentlal } \\
\text { (kiiopascais) }\end{array}$} \\
\hline & & & Composite & Coarse & Fine & Composite & Coarse & Fine \\
\hline \multicolumn{9}{|l|}{ UE-25 } \\
\hline \multicolumn{9}{|c|}{ UZN \#10--Continued } \\
\hline & $20.36-20.48$ & $\mathbf{R}$ & 0.108 & - & -- & -460 & - & - \\
\hline & $20.57-20.63$ & $\mathbf{R}$ & .163 & - & -- & -430 & -- & -- \\
\hline & $20.94-21.03$ & $\mathbf{R}$ & .099 & - & -- & -490 & -- & - \\
\hline & $21.43-21.52$ & $\mathrm{R}$ & .119 & - & -- & -480 & - & - \\
\hline & $22.01-22.10$ & $\mathbf{R}$ & .112 & - & -- & -430 & - & - \\
\hline & $22.40-22.43$ & $\mathbf{R}$ & .165 & - & -. & -630 & - & -- \\
\hline & $22.59-22.71$ & $\mathbf{R}$ & .103 & - & -- & -640 & - & - \\
\hline & $23.32-23.38$ & $\mathbf{R}$ & .089 & -- & -. & -550 & - & - \\
\hline & $29.11-29.17$ & $\mathbf{R}$ & .185 & - & -. & -570 & - & -- \\
\hline & $29.93-3.08$ & $\mathbf{R}$ & .123 & - & - & -950 & - & - \\
\hline UE-25 & $1.5-2.1$ & D & .083 & -- & -- & -340 & -220 & -350 \\
\hline \multirow[t]{9}{*}{ UZN \#12 } & $3.0-3.7$ & D & .054 & - & -- & -370 & -260 & -390 \\
\hline & $4.6-5.2$ & D & .056 & - & -- & -150 & -300 & -280 \\
\hline & $6.1-6.7$ & D & .058 & - & -- & -110 & -78 & -280 \\
\hline & $6.1-6.7$ & D & - & -- & -- & -200 & -350 & -580 \\
\hline & $7.6-8.2$ & D & .053 & -- & -- & -170 & -120 & -200 \\
\hline & $9.1-9.8$ & D & .053 & - & -- & -180 & -270 & -330 \\
\hline & $9.1-9.8$ & D & - & - & -- & -150 & - & -260 \\
\hline & $10.7-11.3$ & D & .036 & -- & -- & -230 & -92 & -300 \\
\hline & $12.2-12.8$ & $\mathrm{D}$ & .041 & - & -- & -210 & -220 & -320 \\
\hline UE-25 & $1.5-2.1$ & D & .048 & -- & -- & - & - & - \\
\hline \multirow[t]{13}{*}{ UZN \#13 } & $3.0-3.7$ & $\mathrm{D}$ & .084 & -- & -- & -190 & -140 & - \\
\hline & $3.0-3.7$ & D & - & -- & -- & - & -180 & - \\
\hline & $4.6-5.2$ & $\mathrm{D}$ & .067 & -- & - & -200 & -110 & -67 \\
\hline & $4.6-5.2$ & D & - & -- & - & - & -160 & - \\
\hline & $6.1-6.7$ & D & .073 & -- & - & -150 & -150 & - \\
\hline & $7.6-8.2$ & D & .061 & -- & - & - & -140 & -94 \\
\hline & $7.6-8.2$ & D & - & -- & - & - & -200 & -160 \\
\hline & $9.1-9.8$ & $\mathrm{D}$ & .070 & -- & - & -260 & -53 & -50 \\
\hline & $9.1-9.8$ & D & -- & -- & -- & - & -180 & - \\
\hline & $10.7-11.3$ & D & .084 & - & -- & -190 & -100 & -88 \\
\hline & $10.7-11.3$ & D & - & -- & -- & - & -250 & - \\
\hline & $12.2-12.8$ & D & .099 & -- & -- & -150 & -160 & -50 \\
\hline & $12.2-12.8$ & D & -- & -- & -- & -- & -50 & - \\
\hline
\end{tabular}


Table 5. Results of laboratory analyses of hydrologic characteristics of core samples from selected neutron-access boreholes--Continued

\begin{tabular}{|c|c|c|c|c|c|c|c|c|}
\hline \multirow{2}{*}{$\begin{array}{l}\text { Neutron- } \\
\text { access } \\
\text { borehole } \\
\text { number }\end{array}$} & \multirow[t]{2}{*}{$\begin{array}{l}\text { Depth } \\
\text { interval } \\
\text { (meters) }\end{array}$} & \multirow[t]{2}{*}{ Core type } & \multicolumn{3}{|c|}{$\begin{array}{l}\text { Gravimetric water content } \\
\text { (grams per gram) }\end{array}$} & \multicolumn{3}{|c|}{$\begin{array}{l}\text { Water potential } \\
\text { (kiiopascais) }\end{array}$} \\
\hline & & & Composite & Coarse & Fine & Composite & Coarse & Fine \\
\hline UE-25 & $1.5-2.1$ & $\bar{D}$ & 0.044 & -- & -- & -- & -210 & -290 \\
\hline \multirow[t]{11}{*}{ UZN \#14 } & $1.5-2.1$ & D & -- & -- & -- & - & -450 & - \\
\hline & $3.0-3.7$ & D & .031 & -- & -- & - & $-3,300$ & 2,800 \\
\hline & $3.0-3.7$ & $\mathrm{D}$ & - & - & -- & - & $-4,200$ & - \\
\hline & $4.6-5.2$ & $\mathrm{D}$ & .038 & -- & - & -- & $-800-1,700$ & \\
\hline & $4.6-5.2$ & $\mathrm{D}$ & -- & - & -- & - & $-1,100$ & -- \\
\hline & $6.1-6.7$ & $\mathrm{D}$ & .043 & - & -- & - & -820 & -980 \\
\hline & $7.6-8.2$ & $\mathrm{D}$ & - & - & - & - & -800 & -560 \\
\hline & $9.1-9.8$ & D & .055 & -- & -- & - & -570 & -390 \\
\hline & $10.7-11.3$ & $\mathrm{D}$ & .043 & -- & -- & - & -540 & -340 \\
\hline & $12.2-12.8$ & $\mathrm{D}$ & .048 & -- & -- & - & -540 & -230 \\
\hline & $13.7-14.3$ & D & .046 & -- & -- & - & -450 & -320 \\
\hline UE-25 & $0.53-0.61$ & D & .035 & -- & -- & $-3,400$ & -- & - \\
\hline \multirow[t]{6}{*}{ UZN \#19 } & $2.13-2.21$ & D & .048 & -- & -- & -500 & - & -. \\
\hline & $3.66-3.73$ & D & .067 & -- & - & -400 & - & -- \\
\hline & $5.26-5.33$ & D & .078 & -- & -- & -380 & - & - \\
\hline & $6.40-6.48$ & D & .067 & -- & - & -410 & - & - \\
\hline & $7.92-8.00$ & $\mathbf{R}$ & .029 & -- & -- & $-17,000$ & - & -- \\
\hline & $9.45-9.54$ & $\mathbf{R}$ & .031 & -- & - & $-1,300$ & - &.- \\
\hline UE-25 & $0.00-0.53$ & $\mathrm{D}$ & .022 & -- & -- & - & - & - \\
\hline \multirow[t]{13}{*}{$\mathrm{UZN} \# 21$} & $0.23-0.30$ & D & .028 & -- & -- & $-2,800$ & -- & -- \\
\hline & $1.83-1.98$ & $\mathrm{D}$ & .017 & -- & -- & $-6,000$ & -- & - \\
\hline & $1.83-2.44$ & D & .022 & -- & -- & - & - & -- \\
\hline & $3.35-3.43$ & D & .031 & -- & -- & $-3,300$ & -- & - \\
\hline & $3.35-3.66$ & D & .042 & -- & -- & - & - & - \\
\hline & $4.88-5.33$ & D & .029 & -- & - & - & -- & $\cdots$ \\
\hline & $5.26-5.33$ & $\mathrm{D}$ & .024 & -- & - & $-7,000$ & - & - \\
\hline & $6.40-6.55$ & D & .024 & -- & -- & $-13,000$ & - & - \\
\hline & $6.40-7.01$ & D & .031 & -- & -- & - & - & -- \\
\hline & $7.92-8.08$ & $\mathrm{D}$ & .033 & -- & -- & $-20,000$ & - & -- \\
\hline & $7.92-8.38$ & $\mathrm{D}$ & .031 & - & - & - & - & - \\
\hline & $10.97-11.09$ & $\mathbf{R}$ & .033 & -- & -- & -610 & - & -. \\
\hline & $12.19-12.31$ & $\mathbf{R}$ & .030 & - & - & $-4,100$ & - & -- \\
\hline UE-25 & $0.00-0.61$ & $\mathrm{D}$ & .098 & -- & -- & -- & -- & -- \\
\hline \multirow[t]{4}{*}{$\mathrm{UZN} \# 22$} & $0.30-0.38$ & D & .053 & -- & -- & -540 & -- & -- \\
\hline & $1.83-2.44$ & $\mathrm{D}$ & .025 & -- & -- & - & - & - \\
\hline & $2.06-2.13$ & D & .024 & -- & - & $-6,700$ & -- & -- \\
\hline & $4.88-5.03$ & D & .069 & -- & - & - & -- &.- \\
\hline
\end{tabular}


Table 5. Results of laboratory analyses of hydrologic characteristics of core samples from selected neutron-access boreholes--Continued

\begin{tabular}{|c|c|c|c|c|c|c|c|c|}
\hline \multirow{2}{*}{$\begin{array}{l}\text { Neutron- } \\
\text { access } \\
\text { borehole } \\
\text { number }\end{array}$} & \multirow[t]{2}{*}{$\begin{array}{l}\text { Depth } \\
\text { interval } \\
\text { (meters) }\end{array}$} & \multirow[t]{2}{*}{ Core type } & \multicolumn{3}{|c|}{$\begin{array}{l}\text { Gravimetric water content } \\
\text { (grams per gram) }\end{array}$} & \multicolumn{3}{|c|}{$\begin{array}{l}\text { Water potential } \\
\text { (kilopascals) }\end{array}$} \\
\hline & & & Composite & Coarse & Fine & Composite & Coarse & Fine \\
\hline \multicolumn{9}{|c|}{ UE-25 } \\
\hline \multicolumn{9}{|c|}{ UZN \#22--Continued } \\
\hline & $4.88-5.18$ & D & 0.089 & -- & - & - & -- & -- \\
\hline & $4.95-5.03$ & D & - & - & - & -600 & - & - \\
\hline & $11.19-11.31$ & $\mathbf{R}$ & .030 & -- & - & $-10,000$ & -- & - \\
\hline & $28.86-28.93$ & $\mathbf{R}$ & .028 & - & - & $-6,900$ & - & -- \\
\hline UE-25 & $0.30-0.43$ & $\mathbf{R}$ & .033 & -- & - & $-1,600$ & - & - \\
\hline \multirow[t]{12}{*}{$\mathrm{UZN} \# 23$} & $0.91-1.02$ & $\mathbf{R}$ & .051 & - & - & $-1,300$ & -- & - \\
\hline & $1.02-1.17$ & $\mathbf{R}$ & .025 & -- & - & $-10,000$ & - & - \\
\hline & $1.52-1.62$ & $\mathbf{R}$ & .034 & - & -- & $-8,500$ & - & - \\
\hline & $1.94-2.01$ & $\mathbf{R}$ & .028 & -- & -- & $-7,500$ & - & - \\
\hline & $2.74-2.85$ & $\mathbf{R}$ & .030 & - & - & $-8,300$ & - & - \\
\hline & $5.18-5.24$ & $\mathbf{R}$ & .028 & -- & - & $-9,600$ & - & - \\
\hline & $6.71-6.83$ & $\mathbf{R}$ & .027 & -- & -- & $-3,600$ & -- & - \\
\hline & $7.86-7.92$ & $\mathbf{R}$ & .027 & - & - & -890 & - & - \\
\hline & $8.66-8.75$ & $\mathbf{R}$ & .025 & - & - & $-10,000$ & - & - \\
\hline & $9.36-9.45$ & $\mathbf{R}$ & .029 & - & -- & $-10,000$ & - & - \\
\hline & $9.60-9.69$ & $\mathbf{R}$ & .025 & - & -- & $-11,000$ & - & -- \\
\hline & $10.42-10.52$ & $\mathbf{R}$ & .052 & - & -- & $-5,100$ & -- & - \\
\hline USW & $0.0-0.15$ & $\mathbf{R}$ & .076 & - & - & -520 & - & - \\
\hline \multirow{19}{*}{ UZ-N24 } & $2.56-2.71$ & $\mathbf{R}$ & .063 & - & - & -700 & - & - \\
\hline & $5.52-5.56$ & $\mathbf{R}$ & .091 & - & -- & -580 & - & - \\
\hline & $8.08-8.15$ & $\mathbf{R}$ & .097 & - & -- & -760 & -- & - \\
\hline & $8.72-8.79$ & $\mathbf{R}$ & .242 & - & - & $-1,000$ & - & - \\
\hline & $8.99-9.05$ & $\mathbf{R}$ & .250 & - & - & -720 & -- & - \\
\hline & $9.28-9.36$ & $\mathbf{R}$ & .311 & - & -- & -720 & -- & - \\
\hline & $9.75-9.81$ & $\mathbf{R}$ & .235 & - & -- & -610 & - & - \\
\hline & $9.88-9.97$ & $\mathbf{R}$ & .215 & -- & -- & -580 & -- & - \\
\hline & $10.61-10.67$ & $\mathbf{R}$ & .164 & -- & -- & -740 & - & - \\
\hline & $10.81-10.90$ & $\mathbf{R}$ & .165 & - & - & -940 & - & - \\
\hline & $11.02-11.06$ & $\mathbf{R}$ & .149 & -- & -- & $-1,200$ & - & - \\
\hline & $11.48-11.60$ & $\mathbf{R}$ & .155 & - & -- & -880 & - & - \\
\hline & $11.73-11.86$ & $\mathbf{R}$ & .166 & - & - & -690 & - & - \\
\hline & $12.19-12.34$ & $\mathbf{R}$ & .168 & -- & -- & .740 & - & - \\
\hline & $13.66-13.72$ & $\mathbf{R}$ & .197 & - & -- & -580 & - & - \\
\hline & $13.72-13.81$ & $\mathbf{R}$ & .206 & - & -- & -470 & -- & - \\
\hline & $14.72-14.78$ & $\mathbf{R}$ & .303 & - & -- & -420 & -- & - \\
\hline & $15.58-15.64$ & $\mathbf{R}$ & .350 & - & -- & -410 & -- & - \\
\hline & $15.91-16.00$ & $\mathbf{R}$ & .342 & - & -- & -430 & - & - \\
\hline
\end{tabular}


Table 5. Results of laboratory analyses of hydrologic characteristics of core samples from selected neutron-access boreholes--Continued

\begin{tabular}{|c|c|c|c|c|c|c|c|c|}
\hline \multirow{2}{*}{$\begin{array}{l}\text { Neutron- } \\
\text { access } \\
\text { borehole } \\
\text { number }\end{array}$} & \multirow[t]{2}{*}{$\begin{array}{l}\text { Depth } \\
\text { interval } \\
\text { (meters) }\end{array}$} & \multirow[t]{2}{*}{ Core type } & \multicolumn{3}{|c|}{$\begin{array}{l}\text { Gravimetric water content } \\
\text { (grams per gram) }\end{array}$} & \multicolumn{3}{|c|}{$\begin{array}{l}\text { Water potentia' } \\
\text { (kilopascals) }\end{array}$} \\
\hline & & & Composite & Coarse & Fine & Composite & Coarse & Fine \\
\hline \multicolumn{9}{|c|}{ USW } \\
\hline \multicolumn{9}{|c|}{ UZ-N24--Continued } \\
\hline & $16.84-16.95$ & $\mathbf{R}$ & 0.311 & - & -- & -430 & - & -- \\
\hline & $17.37-17.47$ & $\mathbf{R}$ & .260 & - & -. & -430 & - & -- \\
\hline & $17.82-17.89$ & $\mathbf{R}$ & .246 & -- & - & -430 & - & -- \\
\hline & $18.17-18.24$ & $\mathbf{R}$ & .231 & -- & -- & -440 & - & -- \\
\hline & $18.29-18.59$ & $\mathbf{R}$ & .218 & - & -- & -460 & -- & - \\
\hline & $19.05-19.14$ & $\mathbf{R}$ & .210 & - & -- & -420 & -- & - \\
\hline & $19.51-19.57$ & $\mathbf{R}$ & .202 & -- & -- & -380 & -- & - \\
\hline & $20.12-20.25$ & $\mathbf{R}$ & .195 & -- & -- & -350 & - & -- \\
\hline & $20.82-20.91$ & $\mathbf{R}$ & .443 & - & -- & -390 & - & - \\
\hline & $21.21-21.55$ & $\mathbf{R}$ & .415 & -- & -- & -330 & - & - \\
\hline & $21.58-21.67$ & $\mathbf{R}$ & .196 & -- & - & -330 & - & - \\
\hline & $21.82-21.92$ & $\mathbf{R}$ & .185 & -- & -- & -330 & - & -- \\
\hline & $22.16-22.25$ & $\mathbf{R}$ & .180 & - & -- & -490 & - & -- \\
\hline & $22.66-22.77$ & $\mathbf{R}$ & .180 & -- & -- & -530 & - & -- \\
\hline USW & $1.83-1.98$ & $\mathbf{R}$ & .031 & -- & -- & $-6,400$ & - & -- \\
\hline \multirow[t]{5}{*}{ UZ-N25 } & $3.35-3.38$ & $\mathbf{R}$ & .039 & -- & -- & $-5,300$ & - & -- \\
\hline & $4.88-5.00$ & $\mathbf{R}$ & .023 & -- & -- & $-9,000$ & - & - \\
\hline & $1.52-1.68$ & $\mathbf{R}$ & .021 & -- & -- & $-8,000$ & -- & -- \\
\hline & $4.88-5.03$ & $\mathbf{R}$ & .022 & -- & - & $-12,000$ & -- & -- \\
\hline & $7.92-8.08$ & $\mathbf{R}$ & .023 & -- & -- & $-8,800$ & -- & -- \\
\hline UE-25 & $0.0-0.08$ & D & .070 & -- & - & -410 & - & - \\
\hline \multirow[t]{8}{*}{$\mathrm{UZN} \# 28$} & $1.83-2.44$ & D & .044 & -- & -- & - & -- & -- \\
\hline & $2.21-2.29$ & D & .048 & - & -- & $-1,300$ & - & -- \\
\hline & $3.35-3.96$ & D & .038 & - & -- & -- & - & -- \\
\hline & $3.58-3.66$ & $\mathrm{D}$ & .039 & -- & -- & $-1,100$ & - & -- \\
\hline & $4.88-5.49$ & D & .059 & -- & -- & -- & - & -- \\
\hline & $5.26-5.33$ & D & .061 & -- & -- & -790 & - & -- \\
\hline & $6.40-7.01$ & D & .061 & -- & -- & -- & -- & - \\
\hline & $6.78-6.86$ & D & .055 & -- & -- & -960 & -- & -- \\
\hline UE-25 & $0.12-0.15$ & D & .078 & - & - & -450 & - & -- \\
\hline \multirow[t]{5}{*}{ UZN \#29 } & $1.68-1.77$ & $\mathbf{R}$ & .034 & -- & -- & $-5,800$ & - & - \\
\hline & $3.44-3.51$ & $\mathbf{R}$ & .047 & -- & -- & $-4,800$ & - & - \\
\hline & $4.88-4.94$ & $\mathbf{R}$ & .038 & -- & -- & $-2,500$ & - & -- \\
\hline & $6.61-6.71$ & $\mathbf{R}$ & .041 & -- & -- & -640 & - & -- \\
\hline & $7.92-8.38$ & $\mathbf{R}$ & .047 & -- & -- & -690 & - & -- \\
\hline
\end{tabular}


Table 5. Results of laboratory analyses of hydrologic characteristics of core samples from selected neutron-access boreholes--Continued

\begin{tabular}{|c|c|c|c|c|c|c|c|c|}
\hline \multirow{2}{*}{$\begin{array}{l}\text { Neutron- } \\
\text { access } \\
\text { borehoie } \\
\text { number }\end{array}$} & \multirow[t]{2}{*}{$\begin{array}{l}\text { Depth } \\
\text { intervai } \\
\text { (meters) }\end{array}$} & \multirow[t]{2}{*}{ Core type } & \multicolumn{3}{|c|}{$\begin{array}{l}\text { Gravimetric water content } \\
\text { (grams per gram) }\end{array}$} & \multicolumn{3}{|c|}{$\begin{array}{l}\text { Water potentlal } \\
\text { (kilopascals) }\end{array}$} \\
\hline & & & Composite & Coarse & Fine & Composite & Coarse & Fine \\
\hline UE-25 & $0.20-0.23$ & $\mathrm{D}$ & 0.029 & -- & - & -490 & - & - \\
\hline \multirow[t]{2}{*}{ UZN \#30 } & $3.58-3.66$ & $\mathbf{R}$ & .038 & -- & -- & $-3,200$ & - & - \\
\hline & $9.85-9.97$ & $\mathbf{R}$ & .037 & - & -- & $-3,100$ & -- & - \\
\hline USW & $0.08-0.15$ & $\mathrm{D}$ & .082 & - & - & -690 & -. & - \\
\hline \multirow[t]{7}{*}{ UZ-N40 } & $0.70-0.76$ & $\mathbf{R}$ & .024 & - & -- & $-4,200$ & -- & - \\
\hline & $2.38-2.44$ & $\mathbf{R}$ & .040 & - & -- & -530 & -- & -- \\
\hline & $3.35-3.47$ & $\mathbf{R}$ & .028 & -. & -- & -760 & -. & - \\
\hline & $5.39-5.43$ & $\mathbf{R}$ & .029 & - & - & -- & - & - \\
\hline & 5.39-5.49 & $\mathbf{R}$ & - & - & - & $-3,200$ & -- & - \\
\hline & $6.86-7.01$ & $\mathbf{R}$ & .022 & - & - & $-5,400$ & - & - \\
\hline & $9.91-10.06$ & $\mathbf{R}$ & .026 & -- & -- & $-3,900$ & - & - \\
\hline USW & $0.38-0.46$ & $\mathrm{D}$ & .096 & -- & -- & -770 & - & - \\
\hline \multirow[t]{7}{*}{ UZ-N41 } & $0.38-0.46$ & $\mathrm{D}$ & .089 & -- & - & - & - & - \\
\hline & $1.98-2.06$ & $\mathrm{D}$ & .043 & -- & - & $-1,600$ & - & - \\
\hline & $1.98-2.06$ & $\mathrm{D}$ & .050 & - & -- & -- & -- & - \\
\hline & $3.81-3.96$ & D & .071 & - & - & -680 & -- & -- \\
\hline & $4.88-5.06$ & $\mathbf{R}$ & .022 & - & -. & $-5,900$ & -. & - \\
\hline & $6.52-6.71$ & $\mathbf{R}$ & .026 & -- & -- & -- & - & - \\
\hline & $10.67-10.76$ & $\mathbf{R}$ & .022 & - & -- & $-9,300$ & - & - \\
\hline USW & $0.61-0.73$ & $\mathbf{R}$ & .025 & - & -- & $-10,000$ & -. & - \\
\hline \multirow[t]{6}{*}{ UZ-N42 } & $3.54-3.66$ & $\mathbf{R}$ & .025 & -- & -- & $-21,000$ & - & - \\
\hline & $4.51-4.75$ & $\mathbf{R}$ & .028 & -- & -- & $-8,200$ & - & -- \\
\hline & $6.40-6.49$ & $\mathbf{R}$ & .024 & - & -- & $-11,000$ & -- & - \\
\hline & $6.92-7.01$ & $\mathbf{R}$ & .025 & - & -- & $-13,000$ & -- & - \\
\hline & $10.76-10.88$ & $\mathbf{R}$ & .021 & -- & -- & $-22,000$ & - & - \\
\hline & $11.89-12.04$ & $\mathbf{R}$ & .022 & - & -- & $-9,900$ & - & - \\
\hline USW & $0.0-0.15$ & $\mathrm{D}$ & .110 & - & -- & -570 & -- & -- \\
\hline \multirow{7}{*}{ UZ-N43 } & $1.83-1.98$ & D & - & -- & -- & $-6,100$ & -- & - \\
\hline & $4.88-5.03$ & $\mathrm{D}$ & .027 & - & -. & $-8,100$ & -- & -- \\
\hline & $6.55-6.63$ & $\mathrm{D}$ & .029 & - & -- & $-7,300$ & - & -- \\
\hline & $9.33-9.39$ & $\mathbf{R}$ & -- & -- & -- & $-36,000$ & -- & -- \\
\hline & $9.97-10.03$ & $\mathbf{R}$ & .022 & -- & -- & $-23,000$ & -- & -- \\
\hline & $10.67-10.82$ & $\mathbf{R}$ & .021 & -- & - & $-26,000$ & - & -- \\
\hline & $11.37-11.46$ & $\mathbf{R}$ & .021 & -- & -- & $-35,000$ & -- & - \\
\hline
\end{tabular}


Table 5. Results of laboratory analyses of hydrologic characteristics of core samples from selected neutron-accers boreholes--Continued

\begin{tabular}{|c|c|c|c|c|c|c|c|c|}
\hline \multirow{2}{*}{$\begin{array}{l}\text { Neutron- } \\
\text { access } \\
\text { borehole } \\
\text { number }\end{array}$} & \multirow[t]{2}{*}{$\begin{array}{c}\text { Depth } \\
\text { interval } \\
\text { (meters) }\end{array}$} & \multirow[t]{2}{*}{ Core type } & \multicolumn{3}{|c|}{$\begin{array}{l}\text { Gravimetric water content } \\
\text { (grams per gram) }\end{array}$} & \multicolumn{3}{|c|}{$\begin{array}{l}\text { Water potentlal } \\
\text { (kliopascais) }\end{array}$} \\
\hline & & & Composite & Coarse & Fine & Composite & Coarse & Fine \\
\hline USW & $1.74-1.86$ & $\mathbf{R}$ & 0.019 & -- & - & $-14,000$ & - & - \\
\hline \multirow[t]{6}{*}{ UZ-N44 } & $2.71-2.83$ & $\mathbf{R}$ & .024 & -- & -- & $-7,900$ & - & -- \\
\hline & $4.57-4.69$ & $\mathbf{R}$ & .020 & -- & - & $-42,000$ & - & -- \\
\hline & $5.09-5.18$ & $\mathbf{R}$ & .017 & -- & -- & $-37,000$ & - & -- \\
\hline & $7.92-8.08$ & $\mathbf{R}$ & .020 & -- & -- & $-40,000$ & - & -- \\
\hline & $8.38-8.53$ & $\mathbf{R}$ & .024 & -- & -- & $-42,000$ & - & -- \\
\hline & $10.97-11.00$ & $\mathbf{R}$ & .023 & -- & - & $-17,000$ & - & - \\
\hline USW & $0.30-0.38$ & D & .066 & - & - & -480 & - & - \\
\hline \multirow[t]{17}{*}{ UZ-N45 } & $2.06-2.13$ & D & .032 & - & -- & $-6,100$ & - & - \\
\hline & $3.35-3.96$ & D & .080 & -- & -- & -- & - & - \\
\hline & $3.58-3.66$ & D & .113 & -- & -- & -630 & -- & -- \\
\hline & $4.88-5.49$ & D & .068 & -- & -- & - & - & -- \\
\hline & $5.11-5.18$ & D & .065 & -- & -- & -550 & - & -- \\
\hline & $6.40-7.01$ & D & .063 & - & -- & - & - & - \\
\hline & $6.71-6.78$ & D & .067 & -- & -- & -590 & - & - \\
\hline & $7.62-8.23$ & D & .057 & - & -- & - & - & - \\
\hline & $7.92-8.00$ & D & .083 & - & -- & -570 & - & - \\
\hline & $9.14-9.75$ & $D$ & .061 & - & -- & - & - & - \\
\hline & $9.45-9.52$ & D & .070 & -- & -- & -460 & - & - \\
\hline & $10.67-10.76$ & D & .066 & -- & -- & - & - & - \\
\hline & $10.76-10.82$ & $\mathbf{R}$ & .016 & -- & -- & $-35,000$ & - & - \\
\hline & $10.82-11.00$ & $\mathbf{R}$ & .019 & -- & -- & $-28,000$ & - & -- \\
\hline & $11.52-11.58$ & $\mathbf{R}$ & .024 & -- & -- & $-11,000$ & - & - \\
\hline & $12.19-12.28$ & $\mathbf{R}$ & .022 & -- & -- & - & - & -- \\
\hline & $12.89-12.98$ & $\mathbf{R}$ & .032 & -- & -- & - & - & -- \\
\hline USW & $0.0-0.12$ & $\mathbf{R}$ & .151 & -- & - & -620 & - & -- \\
\hline \multirow[t]{13}{*}{ UZ-N46 } & $0.94-1.04$ & $\mathbf{R}$ & .191 & -- & - & -430 & - & -- \\
\hline & $1.52-1.62$ & $\mathbf{R}$ & .112 & -- & -- & -500 & -- & -- \\
\hline & $2.87-2.96$ & $\mathbf{R}$ & .095 & -- & -- & -480 & -- & -- \\
\hline & $3.57-3.66$ & $\mathbf{R}$ & .079 & -- & -- & -620 & - & -- \\
\hline & $4.12-4.21$ & $\mathbf{R}$ & .081 & -- & -- & -640 & - & -- \\
\hline & $4.57-4.66$ & $\mathbf{R}$ & .044 & -- & - & -990 & - & -- \\
\hline & $5.36-5.46$ & $\mathbf{R}$ & .069 & -- & -- & -550 & - & -- \\
\hline & $6.10-6.19$ & $\mathbf{R}$ & .039 & -- & - & -750 & - & -- \\
\hline & $7.16-7.32$ & $\mathbf{R}$ & .047 & -- & - & -530 & - & .- \\
\hline & $7.99-8.11$ & $\mathbf{R}$ & .053 & - & -- & -580 & - & -- \\
\hline & $8.66-8.81$ & $\mathbf{R}$ & .069 & - & -- & -590 & -- & - \\
\hline & $9.14-9.30$ & $\mathbf{R}$ & .059 & - &.- & -530 & - & -- \\
\hline & $9.82-9.94$ & $\mathbf{R}$ & .080 & - & - & -610 & - & -- \\
\hline
\end{tabular}


Table 5. Results of laboratory analyses of hydrologic characteristics of core samples from selected neutron-access boreholes--Continued

\begin{tabular}{|c|c|c|c|c|c|c|c|c|}
\hline \multirow[t]{2}{*}{$\begin{array}{l}\text { Neutron- } \\
\text { access } \\
\text { borehole } \\
\text { number }\end{array}$} & \multirow[t]{2}{*}{$\begin{array}{l}\text { Depth } \\
\text { Interval } \\
\text { (meters) }\end{array}$} & \multirow[t]{2}{*}{ Core type } & \multicolumn{3}{|c|}{$\begin{array}{l}\text { Gravimetrlc water content } \\
\text { (grams per gram) }\end{array}$} & \multicolumn{3}{|c|}{$\begin{array}{l}\text { Water potentlal } \\
\text { (kllopascals) }\end{array}$} \\
\hline & & & Composite & Coarse & Fine & Composite & Coarse & Fine \\
\hline \multicolumn{9}{|l|}{ USW } \\
\hline \multicolumn{9}{|c|}{ UZ-N46--Continued } \\
\hline & $10.67-10.85$ & $\mathbf{R}$ & 0.062 & - & - & -580 & -- & - \\
\hline & $11.58-11.70$ & $\mathbf{R}$ & .059 & - & -- & -830 & -- & - \\
\hline & $12.25-12.34$ & $\mathbf{R}$ & .067 & -- & - & $-1,100$ & - & - \\
\hline & $13.93-13.99$ & $\mathbf{R}$ & .043 & - & - & $-5,700$ & -- & - \\
\hline & $15.15-15.24$ & $\mathbf{R}$ & .070 & - & -- & -720 & - & - \\
\hline & $15.48-15.58$ & $\mathbf{R}$ & .039 & - & -- & -860 & - & - \\
\hline & $16.25-16.31$ & $\mathbf{R}$ & .041 & -- & -- & $-1,100$ & -- & - \\
\hline & $16.98-17.04$ & $\mathbf{R}$ & .032 & - & -- & $-1,000$ & -- & - \\
\hline & $17.56-17.68$ & $\mathbf{R}$ & .043 & - & - & -750 & -- & - \\
\hline & $23.47-23.59$ & $\mathbf{R}$ & .247 & -. & - & $-8,300$ & -- & - \\
\hline & $23.71-23.80$ & $\mathbf{R}$ & .281 & -- & -- & $-5,400$ & - & - \\
\hline & $23.99-24.08$ & $\mathbf{R}$ & .172 & -- & - & -600 & - & - \\
\hline & $24.32-24.38$ & $\mathbf{R}$ & .231 & -- & -- & -340 & -- & - \\
\hline & $24.78-24.84$ & $\mathbf{R}$ & .233 & - & -- & -480 & -- & - \\
\hline & $25.60-25.70$ & $\mathbf{R}$ & .172 & -- & - & -350 & - & - \\
\hline & $26.34-26.43$ & $\mathbf{R}$ & .194 & - & - & -340 & - & - \\
\hline & $27.04-27.13$ & $\mathbf{R}$ & .289 & - & -- & -360 & -- & - \\
\hline & $27.22-27.26$ & $\mathbf{R}$ & .177 & - & - & -390 & - & - \\
\hline & 27.68-27.77 & $\mathbf{R}$ & .182 & - & -- & -350 & -- & - \\
\hline & $28.53-28.65$ & $\mathbf{R}$ & .136 & - & -. & -340 & -- & - \\
\hline & $28.77-28.83$ & $\mathbf{R}$ & .256 & - & -- & -340 & $-\cdot$ & - \\
\hline & $29.32-29.41$ & $\mathbf{R}$ & .177 & -- & -- & -310 & -- & - \\
\hline & $30.05-30.18$ & $\mathbf{R}$ & .187 & - & -- & -330 & - & - \\
\hline USW & $0.30-0.38$ & $\mathrm{D}$ & .078 & -- & - & -590 & - & - \\
\hline \multirow[t]{14}{*}{ UZ-N47 } & $1.83-1.90$ & $\mathrm{D}$ & .073 & -- & -- & -630 & -- & - \\
\hline & $3.35-3.43$ & $\mathrm{D}$ & .083 & - & -- & -500 & - & - \\
\hline & $4.72-4.95$ & $\mathrm{D}$ & .034 & -- & - & $-5,200$ & - & - \\
\hline & $6.32-6.40$ & $\mathrm{D}$ & .032 & - & - & $-5,800$ & -- & - \\
\hline & $7.92-8.00$ & $\mathrm{D}$ & .033 & -- & -. & $-5,100$ & -- & - \\
\hline & $9.22-9.30$ & $\mathrm{D}$ & .043 & -- & -- & $-2,400$ & -- & -- \\
\hline & $10.67-10.76$ & $\mathbf{R}$ & .042 & - & -- & $-1,000$ & - & - \\
\hline & $11.70-11.80$ & $\mathbf{R}$ & .059 & -- & - & -900 & -- & - \\
\hline & $12.16-12.24$ & $\mathbf{R}$ & .067 & - & -- & -690 & - & - \\
\hline & $12.44-12.50$ & $\mathbf{R}$ & .070 & -- & -- & -900 & - & - \\
\hline & $16.82-16.92$ & $\mathbf{R}$ & .051 & -- & - & $-1,700$ & - & - \\
\hline & $17.25-17.37$ & $\mathbf{R}$ & .054 & -- & -- & -920 & -- & - \\
\hline & $21.46-21.52$ & $\mathbf{R}$ & .326 & -- & -- & -860 & -- & - \\
\hline & $21.64-21.73$ & $\mathbf{R}$ & .224 & - & -- & -560 & - & - \\
\hline
\end{tabular}


Table 5. Results of laboratory analyses of hydrologic characteristics of core samples from selected neutron-access boreholes--Continued

\begin{tabular}{|c|c|c|c|c|c|c|c|c|}
\hline \multirow[t]{2}{*}{$\begin{array}{l}\text { Neutron- } \\
\text { access } \\
\text { borehole } \\
\text { number }\end{array}$} & \multirow[t]{2}{*}{$\begin{array}{l}\text { Depth } \\
\text { interval } \\
\text { (meters) }\end{array}$} & \multirow[t]{2}{*}{ Core type } & \multicolumn{3}{|c|}{$\begin{array}{l}\text { Gravlmetric water content } \\
\text { (grams per gram) }\end{array}$} & \multicolumn{3}{|c|}{$\begin{array}{l}\text { Water potential } \\
\text { (kilopascals) }\end{array}$} \\
\hline & & & Composite & Coarse & Fine & Composite & Coarse & Fine \\
\hline \multicolumn{9}{|l|}{ USW } \\
\hline \multicolumn{9}{|c|}{ UZ-N47--Continued } \\
\hline & $22.31-22.40$ & $\mathbf{R}$ & 0.251 & -- & -- & -380 & - & -- \\
\hline & $22.74-22.80$ & $\mathbf{R}$ & .326 & -- & -- & -520 & - & -- \\
\hline & $23.09-23.16$ & $\mathbf{R}$ & .297 & -- & - & -460 & - & - \\
\hline & $23.56-23.64$ & $\mathbf{R}$ & .294 & - & -- & -430 & - & -- \\
\hline & $23.99-24.08$ & $\mathbf{R}$ & .314 & - & - & -600 & - & -- \\
\hline & $24.32-24.38$ & $\mathbf{R}$ & .223 & - & -- & -560 & - & -- \\
\hline & $24.64-24.72$ & $\mathbf{R}$ & .199 & -- & - & -550 & -- & - \\
\hline & $25.02-25.12$ & $\mathbf{R}$ & .183 & -- & -. & -650 & - & - \\
\hline & $25.51-25.59$ & $\mathbf{R}$ & .155 & -- & -- & -580 & - & - \\
\hline & $26.06-26.12$ & $\mathbf{R}$ & .265 & -- & -- & -600 & - & -- \\
\hline USW & $1.62-1.68$ & $\mathbf{R}$ & .027 & -- & -. & $-28,000$ & -- & - \\
\hline \multirow[t]{2}{*}{ UZ-N48 } & $4.82-4.88$ & $\mathbf{R}$ & .024 & - & -. & $-42,000$ & -- & - \\
\hline & $7.62-7.68$ & $\mathbf{R}$ & .023 & - & -. & $-31,000$ & - & -- \\
\hline USW & $0.0-0.61$ & D & .101 & - & - & - & - & - \\
\hline \multirow[t]{6}{*}{ UZ-N49 } & $0.23-0.30$ & D & .106 & -- & - & -540 & -. & -. \\
\hline & $3.66-3.75$ & $\mathbf{R}$ & .029 & -- & -- & $-12,000$ & - & -- \\
\hline & $3.66-3.75$ & $\mathbf{R}$ & - & -- & -- & $-14,000$ & - & - \\
\hline & $10.67-10.76$ & $\mathbf{R}$ & .026 & - & -- & $-24,000$ & - & -- \\
\hline & $10.67-10.76$ & $\mathbf{R}$ & - & -- & -- & $-26,000$ & - & -- \\
\hline & $0.0-0.6$ & D & .068 & -- & -- & -50 & -50 & -- \\
\hline \multirow[t]{2}{*}{ UZ-N69 } & $1.8-2.4$ & D & .062 & -- & -- & -170 & -160 & -180 \\
\hline & $2.4-3.0$ & D & .052 & -- & -- & -230 & -200 & -210 \\
\hline USW & $2.13-2.38$ & $\mathbf{R}$ & .032 & -- & -- & $-2,800$ & - & -- \\
\hline \multirow[t]{4}{*}{ UZ-N70 } & $5.67-5.79$ & $\mathbf{R}$ & .033 & -- & - & -740 & - & -- \\
\hline & $6.71-6.83$ & $\mathrm{R}$ & .027 & -- & - & $-2,500$ & -- & -- \\
\hline & $8.75-8.81$ & $\mathbf{R}$ & .037 & - & - & -700 & - & - \\
\hline & $10.06-10.12$ & $\mathbf{R}$ & .038 & - & - & -630 & -- & - \\
\hline USW & 3.93-3.99 & $\mathbf{R}$ & .038 & - & -- & -570 & -- & -- \\
\hline \multirow[t]{4}{*}{ UZ-N74 } & $4.11-4.27$ & $\mathbf{R}$ & .020 & - & -. & $-2,500$ & -. & -. \\
\hline & $7.92-7.96$ & $\mathbf{R}$ & .032 & - & -- & - & -. & - \\
\hline & $8.05-8.08$ & $\mathbf{R}$ & .035 & -- & -. & $-15,000$ & -- & -. \\
\hline & $10.67-10.76$ & $\mathbf{R}$ & .036 & -- & -. & $-1,100$ & - & -- \\
\hline
\end{tabular}


Table 5. Results of laboratory analyses of hydrologic characteristics of core samples from selected neutron-access boreholes--Continued

\begin{tabular}{|c|c|c|c|c|c|c|c|c|}
\hline \multirow[t]{2}{*}{$\begin{array}{l}\text { Neutron- } \\
\text { access } \\
\text { borehoie } \\
\text { number }\end{array}$} & \multirow[t]{2}{*}{$\begin{array}{l}\text { Depth } \\
\text { interval } \\
\text { (meters) }\end{array}$} & \multirow[t]{2}{*}{ Core type } & \multicolumn{3}{|c|}{$\begin{array}{l}\text { Gravimetric water content } \\
\text { (grams per gram) }\end{array}$} & \multicolumn{3}{|c|}{$\begin{array}{l}\text { Water potentlai } \\
\text { (kilopascais) }\end{array}$} \\
\hline & & & Composite & Coarse & FIne & Composite & Coarse & Fine \\
\hline USW & $0.09-0.15$ & $\mathrm{D}$ & 0.126 & - & -- & -840 & - & - \\
\hline \multirow[t]{5}{*}{ UZ-N75 } & $1.83-1.98$ & $\mathbf{R}$ & .046 & - & - & -740 & - & -- \\
\hline & $2.87-3.05$ & $\mathbf{R}$ & .049 & - & - & -910 & - & - \\
\hline & $5.09-5.18$ & $\mathbf{R}$ & .043 & -- & - & $-1,300$ & - & - \\
\hline & $8.11-8.20$ & $\mathbf{R}$ & .046 & -. & -- & $-1,000$ & -- & - \\
\hline & $10.88-11.00$ & $\mathbf{R}$ & .051 & -- & -- & -600 & - & - \\
\hline UE-25 & $1.07-1.22$ & D & .027 & - & - & -- & - & - \\
\hline \multirow{28}{*}{ UZN \#85 } & $2.13-2.29$ & D & .059 & - & -- & - & - & -- \\
\hline & $4.04-4.19$ & D & .025 & -- & -- & - & -- & -- \\
\hline & $4.04-4.19$ & D & .023 & -- & -- & - & -- & - \\
\hline & $5.18-5.33$ & D & .017 & -- & -- & - & -- & - \\
\hline & $5.18-5.33$ & D & .020 & - & -- & -- & -- & - \\
\hline & $8.53-8.38$ & D & .017 & -- & -- & -- & -- & - \\
\hline & $8.53-8.38$ & $\mathrm{D}$ & .016 & -- & -- & -- & -- & - \\
\hline & $9.75-9.91$ & $\mathrm{D}$ & .021 & - & -- & - & -. & - \\
\hline & $9.75-9.91$ & $\mathrm{D}$ & .021 & -- & -- & -- & - & - \\
\hline & $11.28-11.43$ & $\mathrm{D}$ & .017 & -- & -- & -- & -- & - \\
\hline & $12.80-12.95$ & $\mathrm{D}$ & .029 & -- & -- & -- & -- & - \\
\hline & $12.80-12.95$ & $\mathrm{D}$ & .037 & - & -- & -- & - & - \\
\hline & $14.33-14.48$ & $\mathrm{D}$ & .035 & - & -- & -- & - & - \\
\hline & $14.33-14.48$ & $\mathrm{D}$ & .025 & - & -- & -- & - & - \\
\hline & $16.46-16.61$ & $\mathrm{D}$ & .029 & - & -- & -- & $-3,400$ & - \\
\hline & $16.84-16.99$ & $\mathrm{D}$ & .038 & - & - & -- & -- & - \\
\hline & $17.37-17.53$ & D & .035 & -- & -- & -- & -. & - \\
\hline & $17.75-17.91$ & D & .035 & - & -- & - & $-2,300$ & - \\
\hline & $17.75-17.91$ & $\mathrm{D}$ & .044 & - & -- & -- & - & - \\
\hline & $18.90-19.05$ & D & .032 & - & -- & -- & $-2,700$ & - \\
\hline & $18.90-19.05$ & D & .039 & - & -- & - & -- & - \\
\hline & $19.28-19.43$ & D & .035 & -- & - & - & -- & - \\
\hline & $20.42-20.57$ & D & .017 & -- & - & -- & $-6,500$ & - \\
\hline & $20.80-20.96$ & D & .033 & -- & -- & -- & - & - \\
\hline & $21.95-22.10$ & D & .030 & - & -- & -- & $-3,500$ & - \\
\hline & $23.47-23.62$ & $\mathrm{D}$ & .032 & -- & -- & -- & $-2,300$ & - \\
\hline & $23.47-23.62$ & $\mathrm{D}$ & .048 & -- & -- & - & -- & - \\
\hline & $23.85-24.00$ & $\mathrm{D}$ & .023 & -- & -- & -- & -- & - \\
\hline
\end{tabular}


Table 5. Results of laboratory analyses of hydrologic characteristics of core samples from selected neutron-acc?ss boreholes--Continued

\begin{tabular}{|c|c|c|c|c|c|c|c|c|}
\hline \multirow{2}{*}{$\begin{array}{c}\text { Neutron- } \\
\text { access } \\
\text { borehole } \\
\text { number }\end{array}$} & \multirow[t]{2}{*}{$\begin{array}{l}\text { Depth } \\
\text { Interval } \\
\text { (meters) }\end{array}$} & \multirow[t]{2}{*}{ Core type } & \multicolumn{3}{|c|}{$\begin{array}{l}\text { Gravimetric water content } \\
\text { (grams per gram) }\end{array}$} & \multicolumn{3}{|c|}{$\begin{array}{l}\text { Water potential } \\
\text { (kilopascais) }\end{array}$} \\
\hline & & & Composite & Coarse & Fine & Composite & Coarse & Fine \\
\hline USW & $0.6-1.2$ & D & 0.041 & -- & -- & -570 & -800 & -720 \\
\hline \multirow{11}{*}{ UZ-N90 } & $1.8-2.4$ & D & .061 & -- & -- & -280 & -390 & -460 \\
\hline & $1.8-2.4$ & D & .066 & -- & -- & - & - & -- \\
\hline & $3.4-4.0$ & D & .068 & - & - & - & -450 & -300 \\
\hline & $3.4-4.0$ & D & .075 & -- & - & - & - & - \\
\hline & $4.9-5.5$ & D & .074 & - & - & -310 & -340 & -370 \\
\hline & $4.9-5.5$ & D & .077 & -- & - & - & - & - \\
\hline & $6.1-6.7$ & D & .082 & -- & -- & -280 & -270 & -370 \\
\hline & $6.1-6.7$ & D & .111 & -- & -- & - & - & - \\
\hline & $7.9-8.5$ & D & .083 & -- & -. & -- & - & -. \\
\hline & $7.9-8.5$ & D & .070 & -- & .. & - & -- & - \\
\hline & $9.4-9.9$ & D & - & -- & - & -190 & - & -- \\
\hline UE-29 & $0.15-0.23$ & D & .057 & -- & -- & -430 & - & -. \\
\hline \multirow[t]{21}{*}{ UZN \#91 } & $1.75-1.83$ & D & .073 & -- & - & -670 & - & -- \\
\hline & $3.43-3.51$ & D & .097 & -- & -- & -370 & - & -- \\
\hline & $4.80-4.88$ & D & .089 & - & -- & -380 & - & -- \\
\hline & $6.25-6.32$ & D & .071 & -- & - & $-1,000$ & - & -- \\
\hline & $7.77-7.85$ & D & .058 & -- & - & -710 & - & -. \\
\hline & $9.52-9.60$ & D & .072 & - & - & -660 & - & -- \\
\hline & $12.19-12.34$ & D & .081 & -- & - & -540 & - & - \\
\hline & $15.54-15.62$ & D & .110 & -- & -- & -450 & -- & -- \\
\hline & $16.92-16.99$ & D & .105 & -- & - & -370 & - & -- \\
\hline & $18.67-18.74$ & D & .161 & -- & - & -440 & -. & -- \\
\hline & $21.03-21.09$ & $\mathbf{R}$ & .042 & - & - & $-65,000$ & - & -- \\
\hline & $21.03-21.09$ & $\mathbf{R}$ & - & -- & - & $-56,000$ & - & -. \\
\hline & $22.37-22.49$ & $\mathbf{R}$ & .032 & - & -- & $-70,000$ & - & - \\
\hline & $22.37-22.49$ & $\mathbf{R}$ & -- & - & -- & $-65,000$ & -- & -- \\
\hline & $22.74-22.83$ & $\mathbf{R}$ & .026 & -- & -- & $-74,000$ & - & - \\
\hline & $22.74-22.83$ & $\mathbf{R}$ & -- & -- & -- & $-69,000$ & - & - \\
\hline & $23.99-24.08$ & $\mathbf{R}$ & .025 & -- & -- & $-49,000$ & -- & - \\
\hline & $23.99-24.08$ & $\mathbf{R}$ & -- & -- & -- & $-54,000$ & -- & - \\
\hline & $27.80-27.86$ & $\mathbf{R}$ & .055 & -- & - & $-34,000$ & -- & - \\
\hline & $27.80-27.86$ & $\mathbf{R}$ & - & -- & -- & $-39,000$ & - & - \\
\hline & $28.07-28.19$ & $\mathbf{R}$ & .080 & - & -- & -730 & -- & - \\
\hline UE-25 & $0.0-0.61$ & D & .070 & -- & -- & $-1,100$ & -- & - \\
\hline \multirow[t]{4}{*}{ UZN \#92 } & $0.30-0.38$ & D & .078 & -- & -- & $-1,500$ & -- & -- \\
\hline & $1.75-1.83$ & D & .087 & -- & -- & -800 & - & -- \\
\hline & $3.05-3.20$ & D & .056 &.- & -- & $-3,900$ & -- & -- \\
\hline & $4.57-4.72$ & D & .085 & -- & -- & $-2,800$ & - & -. \\
\hline
\end{tabular}


Table 5. Results of laboratory analyses of hydrologic charactenistics of core samples from selected neutron-access boreholes--Continued

\begin{tabular}{|c|c|c|c|c|c|c|c|c|}
\hline \multirow{2}{*}{$\begin{array}{l}\text { Neutron- } \\
\text { access } \\
\text { borehole } \\
\text { number }\end{array}$} & \multirow[t]{2}{*}{$\begin{array}{c}\text { Depth } \\
\text { Intervai } \\
\text { (meters) }\end{array}$} & \multirow[t]{2}{*}{ Core type } & \multicolumn{3}{|c|}{$\begin{array}{l}\text { Gravimetric water content } \\
\text { (grams per gram) }\end{array}$} & \multicolumn{3}{|c|}{$\begin{array}{l}\text { Water potentiai } \\
\text { (kliopascais) }\end{array}$} \\
\hline & & & Composite & Coarse & Fine & Composite & Coarse & Fing \\
\hline \multicolumn{9}{|c|}{ UE-25 } \\
\hline \multicolumn{9}{|c|}{ UZN \#92--Continued } \\
\hline & $6.10-6.25$ & D & 0.080 & -- & -- & $-1,300$ & - & - \\
\hline & $9.14-9.30$ & D & .073 & -- & - & -540 & - & - \\
\hline & $10.90-10.97$ & $\mathrm{D}$ & .072 & - & -- & -700 & -- & -- \\
\hline & $12.19-12.34$ & $\mathrm{D}$ & .059 & - & - & -830 & - & -- \\
\hline & $13.87-13.94$ & $\mathrm{D}$ & .073 & - & - & $-19,000$ & -- & -- \\
\hline & $15.39-15.47$ & $\mathrm{D}$ & .079 & - & -- & $-1,800$ & - & -- \\
\hline & $18.29-18.38$ & $\mathbf{R}$ & .022 & - & -- & $-81,000$ & -- & -- \\
\hline & $18.99-19.08$ & $\mathbf{R}$ & .053 & - & - & $-73,000$ & -- & - \\
\hline & $19.69-19.81$ & $\mathbf{R}$ & .030 & -- & -- & $-77,000$ & - & -- \\
\hline & $19.81-19.84$ & $\mathbf{R}$ & .033 & -- & -- & $-88,000$ & -- & - \\
\hline & $20.12-20.27$ & $\mathbf{R}$ & .023 & -- & -- & $-82,000$ & -- & -- \\
\hline & $20.82-20.91$ & $\mathbf{R}$ & .023 & - & - & $-79,000$ & - & - \\
\hline & $21.70-21.79$ & $\mathbf{R}$ & .020 & -- & - & $-76,000$ & -- & - \\
\hline & $22.49-22.56$ & $\mathbf{R}$ & .022 & - & -- & $-71,000$ & -. & - \\
\hline & $27.52-27.64$ & $\mathbf{R}$ & .009 & - & -- & $-89,000$ & -- & - \\
\hline & $27.89-28.04$ & $\mathbf{R}$ & .026 & - & -- & $-40,000$ & -- & - \\
\hline & $32.13-32.22$ & $\mathbf{R}$ & .016 & -- & - & $-92,000$ & - & - \\
\hline & $32.70-32.80$ & $\mathbf{R}$ & .013 & -- & -- & $-90,000$ & - & - \\
\hline & $33.19-33.53$ & $\mathbf{R}$ & .028 & - & - & $-69,000$ & - & - \\
\hline & $33.53-33.59$ & $\mathbf{R}$ & .040 & - & .- & $-67,000$ & -- & - \\
\hline & $34.90-35.05$ & $\mathbf{R}$ & .008 & - & -- & $-75,000$ & - & - \\
\hline & $35.30-35.54$ & $\mathbf{R}$ & -- & -- & - & $-35,000$ & - & -- \\
\hline & $35.30-35.54$ & $\mathrm{R}$ & - & - & -- & $-35,000$ & - & - \\
\hline & $36.52-36.58$ & $\mathbf{R}$ & .015 & -- & -- & -760 & -- & - \\
\hline UE-25 & $0.27-0.30$ & D & .122 & -- & -- & -520 & -- & - \\
\hline \multirow[t]{12}{*}{ UZN \#97 } & $1.83-2.44$ & $\mathrm{D}$ & -- & -- & -- & -980 & - & - \\
\hline & $2.13-2.21$ & $\mathrm{D}$ & .045 & - & -- & -- & -- & - \\
\hline & $3.35-3.51$ & D & - & - & -- & $-1,000$ & -- & - \\
\hline & $3.66-3.73$ & D & .054 & - & -- & -- & -- &.- \\
\hline & $5.18-5.26$ & D & .058 & - & -- & -640 & -- & - \\
\hline & $6.71-6.78$ & $\mathrm{D}$ & .048 & -- & -- & -740 & -- & - \\
\hline & $7.62-7.70$ & $\mathrm{D}$ & .020 & - & -- & -990 & - & - \\
\hline & $9.37-9.45$ & $\mathrm{D}$ & .045 & -- & -- & -810 & - & - \\
\hline & $10.90-10.97$ & D & .073 & -- & - & -680 & - & - \\
\hline & $12.50-12.57$ & $\mathrm{D}$ & .025 & - & - & $-1,100$ & - & -- \\
\hline & $14.02-14.10$ & D & .048 & -- & -- & -820 & - & - \\
\hline & $16.92-17.07$ & $\mathbf{R}$ & .031 & - & -- & $-1,600$ & - & - \\
\hline
\end{tabular}


Table 5. Results of laboratory analyses of hydrologic characteristics of core samples from selected neutron-access boreholes--Continued

\begin{tabular}{|c|c|c|c|c|c|c|c|c|}
\hline \multirow{2}{*}{$\begin{array}{c}\text { Neutron- } \\
\text { access } \\
\text { borehole } \\
\text { number }\end{array}$} & \multirow[t]{2}{*}{$\begin{array}{l}\text { Depth } \\
\text { Interval } \\
\text { (meters) }\end{array}$} & \multirow[t]{2}{*}{ Core type } & \multicolumn{3}{|c|}{$\begin{array}{l}\text { Gravimetrlc water content } \\
\text { (grams per gram) }\end{array}$} & \multicolumn{3}{|c|}{$\begin{array}{l}\text { Water potentla' } \\
\text { (kllopascals) }\end{array}$} \\
\hline & & & Composite & Coarse & FIne & Composite & Coarse & FIn $\theta$ \\
\hline USW & $7.92-8.23$ & $\bar{R}$ & 0.230 & - & - & $-11,000$ & - & -. \\
\hline \multirow[t]{26}{*}{ UZ-N98 } & $8.69-8.84$ & $\mathrm{R}$ & .322 & -- & -- & -720 & - & - \\
\hline & $9.45-9.63$ & $\mathbf{R}$ & .398 & - & -- & -410 & - & -. \\
\hline & $10.36-10.49$ & $\mathbf{R}$ & .369 & -- & -- & -340 & -- & -- \\
\hline & $11.25-11.34$ & $\mathrm{R}$ & .271 & -- & -- & -350 & -- & -- \\
\hline & $11.70-11.80$ & $\mathrm{R}$ & .266 & - & - & -570 & -- & -- \\
\hline & $12.13-12.19$ & $\mathbf{R}$ & .251 & - & -- & -470 & - & -- \\
\hline & $12.62-12.71$ & $\mathbf{R}$ & .246 & - & -- & -400 & - & - \\
\hline & $13.44-13.56$ & $\mathbf{R}$ & .307 & -- & -- & -360 & - & -- \\
\hline & $13.72-13.84$ & $\mathbf{R}$ & .356 & -- & -- & -290 & -- & -- \\
\hline & $14.51-14.63$ & $\mathbf{R}$ & .312 & -- & -- & -270 & - & -- \\
\hline & $15.24-15.36$ & $\mathbf{R}$ & .320 & - & -- & -390 & - & - \\
\hline & $16.70-16.76$ & $\mathbf{R}$ & .339 & - & -- & -270 & - & - \\
\hline & $16.76-16.82$ & $\mathbf{R}$ & .329 & - & -- & -210 & - & -- \\
\hline & $17.37-17.47$ & $\mathbf{R}$ & .310 & - & -- & -330 & -- & - \\
\hline & $17.74-17.83$ & $\mathbf{R}$ & .279 & -- & -. & -480 & - & -- \\
\hline & $18.23-18.29$ & $\mathbf{R}$ & .259 & -- & -- & -310 & - & -- \\
\hline & $18.53-18.59$ & $\mathbf{R}$ & .264 & -- & -- & -380 & - & -- \\
\hline & $19.00-19.08$ & $\mathbf{R}$ & .257 & -- & -- & -280 & - & - \\
\hline & $19.57-19.66$ & $\mathbf{R}$ & .256 & - & -- & -320 & - & -- \\
\hline & $20.04-20.12$ & $\mathbf{R}$ & .325 & - & -- & -290 & - & -- \\
\hline & $20.45-20.54$ & $\mathbf{R}$ & .505 & - & -- & -350 & - & -- \\
\hline & $20.97-21.06$ & $\mathbf{R}$ & .390 & -- & -- & -330 & - & -- \\
\hline & $21.24-21.34$ & $R$ & .198 & -- & - & -300 & - & - \\
\hline & $21.55-21.64$ & $\mathbf{R}$ & .189 & -. & - & -320 & - & -- \\
\hline & $22.10-22.22$ & $\mathbf{R}$ & .169 & - & -- & -350 & - & -- \\
\hline & $22.52-22.62$ & $\mathbf{R}$ & .162 & -- & -- & -300 & - & -- \\
\hline
\end{tabular}


Table 6. Description of central tendency and dispersion of gravimetric water-content data from coarse drill cuttings as a function of lithology and degree of welding

\begin{tabular}{|c|c|c|c|c|c|c|}
\hline \multirow{2}{*}{ Lithologlc unlt } & \multirow{2}{*}{ Degree of welding } & \multirow{2}{*}{$\begin{array}{l}\text { Number } \\
\text { of } \\
\text { samples }\end{array}$} & \multicolumn{4}{|c|}{$\begin{array}{l}\text { Gravimetrlc water content } \\
\text { (grams per gram) }\end{array}$} \\
\hline & & & Data range & Mean & $\begin{array}{l}\text { Standard } \\
\text { devlatlon }\end{array}$ & Medlan \\
\hline Alluvium/colluvium & Does not apply & $\overline{543}$ & 0.008 to 0.182 & 0.047 & 0.023 & $0.0^{46}$ \\
\hline $\begin{array}{l}\text { Timber Mountain Tuff } \\
\text { Rainier } \\
\text { Mesa Member }{ }^{1}\end{array}$ & Nonwelded to partially & 17 & 0.020 to 0.062 & .039 & .014 & .011 \\
\hline $\begin{array}{l}\text { Paintbrush Tuff } \\
\text { Bedded tuffs }\end{array}$ & Nonwelded & 21 & 0.106 to 0.223 & .155 & .030 & .163 \\
\hline Tiva Canyon Member & Nonwelded to partially & 12 & 0.009 to 0.305 & .112 & .122 & .028 \\
\hline Tiva Canyon Member & Moderately & 186 & 0.007 to 0.313 & .050 & .048 & .036 \\
\hline Tiva Canyon Member & Densely & 682 & 0.008 to 0.096 & .034 & .015 & .031 \\
\hline Yucca Mountain Member & Nonwelded to partially & 74 & 0.035 to 0.290 & .137 & .071 & .139 \\
\hline Yucca Mountain Member & Moderately & 62 & 0.023 to 0.084 & .051 & .014 & .018 \\
\hline Topopah Spring Member & Densely & 24 & 0.015 to 0.040 & .025 & .005 & .025 \\
\hline
\end{tabular}

${ }^{\text {TCmposite of drill-cuttings samples }}$

Table 7. Description of central tendency and dispersion of gravimetric water-content data from composite core samples as a function of lithology and degree of welding

\begin{tabular}{|c|c|c|c|c|c|c|}
\hline \multirow{2}{*}{ Lithologlc unlt } & \multirow{2}{*}{ Degree of welding } & \multirow{2}{*}{$\begin{array}{l}\text { Number } \\
\text { of } \\
\text { samples }\end{array}$} & \multicolumn{4}{|c|}{$\begin{array}{l}\text { Gravimetrlc water content } \\
\text { (grams per gram) }\end{array}$} \\
\hline & & & Data range & Mean & $\begin{array}{l}\text { Standard } \\
\text { devlation }\end{array}$ & Medien \\
\hline Alluvium/colluvium & Does not apply & 169 & 0.017 to 0.161 & 0.058 & 0.026 & 0.058 \\
\hline $\begin{array}{l}\text { Paintbrush Tuff } \\
\text { Bedded tuffs }\end{array}$ & Nonwelded & 38 & 0.123 to 0.505 & .238 & .084 & .210 \\
\hline Tiva Canyon Member & Nonwelded to partially & 34 & 0.149 to 0.398 & .246 & .077 & .246 \\
\hline Tiva Canyon Member & Moderately & 18 & 0.020 to 0.322 & .128 & .111 & .051 \\
\hline Tiva Canyon Member & Densely & 76 & 0.016 to 0.091 & .029 & .011 & .027 \\
\hline Yucca Mountain Member & Nonwelded to partially & 59 & 0.039 to 0.326 & .165 & .071 & .162 \\
\hline Yucca Mountain Member & Moderately & 17 & 0.032 to 0.080 & .055 & .013 & .059 \\
\hline
\end{tabular}


Table 8. Summary of linear-regression analyses for water-content and water-potential values of coarse drill cuttings versus composite core samples for rock types that have different degrees of welding

\begin{tabular}{|c|c|c|c|c|c|c|}
\hline \multirow[b]{2}{*}{ Rock type } & \multirow[b]{2}{*}{ Independent variable } & \multirow[b]{2}{*}{ Dependent variable } & \multirow{2}{*}{$\begin{array}{c}\text { Number } \\
\text { of } \\
\text { samples }\end{array}$} & \multicolumn{3}{|c|}{$\begin{array}{c}\text { Linear regressior equation } \\
\text { paramete-s }\end{array}$} \\
\hline & & & & $\begin{array}{l}\text { Coeffl- } \\
\text { cient of } \\
\text { deter- } \\
\text { mination }\end{array}$ & Intercep & Siope \\
\hline Alluvium/colluvium & $\begin{array}{l}\text { Gravimetric water con- } \\
\text { tent of coarse drill-cut- } \\
\text { ting samples }\end{array}$ & $\begin{array}{l}\text { Gravimetric water con- } \\
\text { tent of composite core } \\
\text { samples }\end{array}$ & 115 & 0.627 & 0.019 & 0.851 \\
\hline $\begin{array}{l}\text { Nonwelded and bedded } \\
\text { tuff }\end{array}$ & $\begin{array}{l}\text { Gravimetric water con- } \\
\text { tent of coarse drill-cut- } \\
\text { ting samples }\end{array}$ & $\begin{array}{l}\text { Gravimetric water con- } \\
\text { tent of composite core } \\
\text { samples }\end{array}$ & 67 & .569 & .05 & .799 \\
\hline $\begin{array}{l}\text { Moderately and densely } \\
\text { welded tuff }\end{array}$ & $\begin{array}{l}\text { Gravimetric water con- } \\
\text { tent of coarse drill-cut- } \\
\text { ting samples }\end{array}$ & $\begin{array}{l}\text { Gravimetric water con- } \\
\text { tent of composite core } \\
\text { samples }\end{array}$ & 77 & .783 & -.011 & 1.503 \\
\hline Alluvium/colluvium & $\begin{array}{l}\text { Water potential of coarse } \\
\text { drill-cutting samples }\end{array}$ & $\begin{array}{l}\text { Water potential of com- } \\
\text { posite core samples }\end{array}$ & 102 & .316 & -518 & .563 \\
\hline $\begin{array}{l}\text { Nonwelded and bedded } \\
\text { tuff }\end{array}$ & $\begin{array}{l}\text { Water potential of coarse } \\
\text { drill-cutting samples }\end{array}$ & $\begin{array}{l}\text { Water potential of com- } \\
\text { posite core samples }\end{array}$ & 54 & .024 & -546 & .175 \\
\hline $\begin{array}{l}\text { Moderately and densely } \\
\text { welded tuff }\end{array}$ & $\begin{array}{l}\text { Water potential of coarse } \\
\text { drill-cutting samples }\end{array}$ & $\begin{array}{l}\text { Water potential of com- } \\
\text { posite core samples }\end{array}$ & 44 & .217 & -5060 & .554 \\
\hline
\end{tabular}

Table 9. Description of central tendency and dispersion of water-content data of coarse drill cuttings from moderately and densely welded lithologic units of the Tiva Canyon Member

\begin{tabular}{llcrrrrr}
\hline & \multirow{2}{*}{$\begin{array}{c}\text { Legree of } \\
\text { weiding }\end{array}$} & $\begin{array}{c}\text { Number of } \\
\text { sampies }\end{array}$ & \multicolumn{4}{c}{$\begin{array}{c}\text { Gravimetric water content } \\
\text { (grams per gram) }\end{array}$} \\
\cline { 5 - 8 } & & & & Data range & Mean & $\begin{array}{c}\text { Standard } \\
\text { deviation }\end{array}$ & Median \\
\hline Caprock & Moderately & 40 & 0.008 to 0.313 & 0.040 & 0.048 & 0.031 \\
Upper cliff & Moderately & 72 & 0.007 to 0.072 & .031 & .016 & .031 \\
Upper lithophysal & Densely & 63 & 0.018 to 0.140 & .058 & .034 & .044 \\
Clinkstone & Densely & 19 & 0.012 to 0.082 & .040 & .024 & .036 \\
Lower lithophysal & Densely & 146 & 0.012 to 0.074 & .035 & .009 & .035 \\
Hackly & Densely & 258 & 0.008 to 0.074 & .030 & .011 & .029 \\
Columnar & Densely & 185 & 0.011 to 0.053 & .027 & .008 & .025 \\
\hline
\end{tabular}


Table 10. Description of central tendency and dispersion of water-content data of composite core samples from moderately and densely welded lithologic units of the Tiva Canyon Member

\begin{tabular}{|c|c|c|c|c|c|c|}
\hline \multirow{2}{*}{ Lithologic unit } & \multirow{2}{*}{$\begin{array}{l}\text { Degree of } \\
\text { welding }\end{array}$} & \multirow{2}{*}{$\begin{array}{l}\text { Number of } \\
\text { sampies }\end{array}$} & \multicolumn{4}{|c|}{$\begin{array}{l}\text { Gravimetric water content } \\
\text { (grams per gram) }\end{array}$} \\
\hline & & & Data range & Mean & $\begin{array}{l}\text { Standard } \\
\text { deviation }\end{array}$ & Median \\
\hline Caprock & Moderately & 8 & 0.020 to 0.049 & 0.037 & 0.009 & 0.038 \\
\hline Upper lithophysal & Densely & 2 & 0.046 to 0.051 & .048 & .004 & .051 \\
\hline Clinkstone & Densely & 1 & 0.034 & & & \\
\hline Lower lithophysal & Densely & 54 & 0.017 to 0.051 & .029 & .007 & .027 \\
\hline Hackly & Densely & 16 & 0.016 to 0.052 & .026 & .008 & .024 \\
\hline Columnar & Densely & 9 & 0.023 to 0.322 & .126 & .110 & .091 \\
\hline
\end{tabular}

Table 11. Description of central tendency and dispersion of water-potential data from coarse drill cuttings as a function of lithology and degree of welding

\begin{tabular}{|c|c|c|c|c|c|c|}
\hline \multirow{2}{*}{ Lithoiogic unit } & \multirow{2}{*}{ Degree of welding } & \multirow{2}{*}{$\begin{array}{l}\text { Number } \\
\text { of } \\
\text { samples }\end{array}$} & \multicolumn{4}{|c|}{$\begin{array}{l}\text { Water potential } \\
\text { (kilopascals) }\end{array}$} \\
\hline & & & Data range & Mean & $\begin{array}{l}\text { Standard } \\
\text { deviation }\end{array}$ & Metlan \\
\hline Alluvium/colluvium & Does not apply & 651 & $-78,000$ to -50 & $-3,411$ & 6,304 & -750 \\
\hline $\begin{array}{l}\text { Timber Mountain Tuff } \\
\text { Rainier } \\
\text { Mesa Member }\end{array}$ & Nonwelded to partially & 9 & -910 to -140 & -438 & 239 & -300 \\
\hline $\begin{array}{l}\text { Paintbrush Tuff } \\
\text { Bedded tuffs }\end{array}$ & Nonwelded & 43 & $-7,200$ to -420 & $-1,267$ & 1,650 & -630 \\
\hline Tiva Canyon Member & Nonwelded to partially & 18 & $-18,000$ to -490 & $-4,762$ & 5,936 & -920 \\
\hline Tiva Canyon Member & Moderately & 204 & $-31,000$ to -220 & $-2,651$ & 5,575 & -650 \\
\hline Tiva Canyon Member & Densely & 687 & $-60,000$ to -140 & $-4,671$ & 5,921 & $-3,200$ \\
\hline Yucca Mountain Member & Nonwelded to partially & 80 & $-3,500$ to -22 & -837 & 576 & -670 \\
\hline Yucca Mountain Member & Moderately & 63 & $-7,500$ to -410 & $-1,193$ & 1,158 & $-\{40$ \\
\hline Topopah Spring Member & Moderately & 24 & $-7,600$ to $-1,400$ & $-3,654$ & 1,568 & $-3,500$ \\
\hline
\end{tabular}

Table 12. Description of central tendency and dispersion of water-potential data from composite core samples as a function of lithology and degree of welding

\begin{tabular}{llcrrrr}
\hline \multirow{2}{*}{ Lithologic unit } & Degree of weiding & \multirow{2}{*}{$\begin{array}{c}\text { Number } \\
\text { of }\end{array}$} & \multicolumn{5}{c}{ Water Potential } \\
\cline { 5 - 7 } & samples & Data range & Mean & $\begin{array}{c}\text { Standard } \\
\text { deviation }\end{array}$ & Merlian \\
\hline Alluvium/colluvium & Does not apply & 117 & $-20,000$ to-50 & $-1,647$ & 3,162 & -550 \\
$\begin{array}{l}\text { Paintbrush Tuff } \\
\quad \text { Bedded tuffs }\end{array}$ & Nonwelded & 38 & -950 to -280 & -422 & 142 & -350 \\
Tiva Canyon Member & Nonwelded to partially & 33 & $-1,200$ to -210 & -517 & 209 & -470 \\
Tiva Canyon Member & Moderately & 17 & $-15,000$ to -570 & $-2,343$ & 4,098 & -760 \\
Tiva Canyon Member & Densely & 73 & $-42,000$ to -530 & $-11,882$ & 11,971 & $-8,370$ \\
Yucca Mountain Member & Nonwelded to partially & 60 & $-8,300$ to -210 & -779 & 1,194 & -550 \\
Yucca Mountain Member & Moderately & 17 & $-5,700$ to -530 & $-1,170$ & 1,198 & -970 \\
\hline
\end{tabular}


Table 13. Description of central tendency and dispersion of water-potential data of drill cuttings from moderately and densely welded lithologic units of the Tiva Canyon Member

\begin{tabular}{|c|c|c|c|c|c|c|}
\hline \multirow[b]{2}{*}{ Lthologic unit } & \multirow{2}{*}{$\begin{array}{l}\text { Degree of } \\
\text { welding }\end{array}$} & \multirow{2}{*}{$\begin{array}{l}\text { Number of } \\
\text { samples }\end{array}$} & \multicolumn{4}{|c|}{ Water potential } \\
\hline & & & Data range & Mean & $\begin{array}{l}\text { Standard } \\
\text { deviation }\end{array}$ & Median \\
\hline Caprock & Moderately & 45 & $-31,000$ to -240 & $-4,774$ & 8,915 & -670 \\
\hline Upper cliff & Moderately & 83 & $-31,000$ to -270 & $-2,945$ & 5,248 & -720 \\
\hline Upper lithophysal & Moderately & 64 & $-6,900$ to -220 & -947 & 1,258 & -530 \\
\hline Upper lithophysal & Densely & 19 & $-11,000$ to -210 & $-2,617$ & 3,277 & -580 \\
\hline Clinkstone & Densely & 145 & $-17,000$ to -240 & $-2,296$ & 2,398 & $-1,600$ \\
\hline Lower lithophysal & Densely & 262 & $-36,000$ to -140 & $-5,327$ & 5,309 & $-4,000$ \\
\hline Hackly & Densely & 177 & $-60,000$ to -220 & $-7,768$ & 8,068 & $-6,100$ \\
\hline Columnar & Densely & 84 & $-15,000$ to -400 & $-3,104$ & 4,054 & -890 \\
\hline Columnar & Moderately & 14 & $-2,900$ to -450 & $-1,561$ & 949 & $-1,800$ \\
\hline
\end{tabular}

Table 14. Description of central tendency and dispersion of water-potential data of composite core samples from moderately and densely welded lithologic units of the Tiva Canyon Member

\begin{tabular}{llrrrrr}
\hline \multirow{2}{*}{ Lithologic unit } & \multirow{2}{*}{$\begin{array}{c}\text { Degree of } \\
\text { welding }\end{array}$} & $\begin{array}{c}\text { Number of } \\
\text { samples }\end{array}$ & Data range & Mean & $\begin{array}{c}\text { Standard } \\
\text { deviation }\end{array}$ & Median \\
\cline { 5 - 7 } & Moderately & 7 & $-15,000$ to -570 & $-3,160$ & 5,259 & $-1,100$ \\
\hline Caprock & Densely & 2 & $-1,000$ to -600 & -800 & 283 & -600 \\
Upper lithophysal & Densely & 1 & $-5,800$ & & & \\
Clinkstone & Densely & 52 & $-42,000$ to -530 & $-10,105$ & 10,550 & $-8,200$ \\
Lower lithophysal & Densely & 15 & $-42,000$ to -610 & $-20,941$ & 14,330 & $-26,000$ \\
Hackly & Densely & 9 & $-11,000$ to -580 & $-3,940$ & 4,097 & $-1,000$ \\
Columnar & & &
\end{tabular}


Table 15. Results of laboratory analyses of physical properties of rotary-core samples from selected neutron-access boreholes

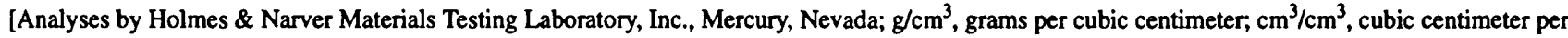
cubic centimeter]

\begin{tabular}{|c|c|c|c|c|}
\hline $\begin{array}{c}\text { Neutron-access borehole } \\
\text { number }\end{array}$ & $\begin{array}{c}\text { Depth } \\
\text { (meters) }\end{array}$ & $\begin{array}{l}\text { Bulk density } \\
\left(\mathrm{g} / \mathrm{cm}^{3}\right)\end{array}$ & $\begin{array}{l}\text { Graln density } \\
\left(\mathrm{g} / \mathrm{cm}^{3}\right)\end{array}$ & $\begin{array}{l}\text { Porosity } \\
\left(\mathrm{cm}^{3} / \mathrm{cm}^{3}\right)\end{array}$ \\
\hline \multirow[t]{35}{*}{ UE-25 UZN \#10 } & 1.22 & 1.52 & 2.44 & 0.377 \\
\hline & 1.83 & 1.54 & 2.42 & .364 \\
\hline & 2.74 & 1.47 & 2.42 & .393 \\
\hline & 4.88 & 1.32 & 2.43 & .457 \\
\hline & 5.64 & 1.28 & 2.43 & .473 \\
\hline & 6.04 & 1.33 & 2.39 & .444 \\
\hline & 6.46 & 1.32 & 2.43 & .457 \\
\hline & 7.59 & 1.26 & 2.41 & .477 \\
\hline & 8.84 & 1.23 & 2.40 & .488 \\
\hline & 1.09 & 1.28 & 2.39 & .464 \\
\hline & 10.97 & 1.31 & 2.38 & .450 \\
\hline & 11.43 & 1.34 & 2.39 & .439 \\
\hline & 11.89 & 1.35 & 2.41 & .440 \\
\hline & 12.31 & 1.38 & 2.40 & .425 \\
\hline & 13.41 & 1.46 & 2.42 & .397 \\
\hline & 13.84 & 1.50 & 2.39 & .372 \\
\hline & 14.33 & 1.52 & 2.40 & .367 \\
\hline & 15.06 & 1.55 & 2.41 & .357 \\
\hline & 15.94 & 1.60 & 2.38 & .328 \\
\hline & 16.67 & 1.58 & 2.40 & .342 \\
\hline & 17.56 & 1.57 & 2.42 & .351 \\
\hline & 18.07 & 1.55 & 2.37 & .346 \\
\hline & 19.11 & 1.49 & 2.39 & .377 \\
\hline & 19.42 & 1.50 & 2.38 & .370 \\
\hline & 19.69 & 1.48 & 2.37 & .376 \\
\hline & 20.36 & 1.40 & 2.37 & .409 \\
\hline & 20.57 & 1.40 & 2.38 & .412 \\
\hline & 20.94 & 1.33 & 2.36 & .436 \\
\hline & 21.43 & 1.28 & 2.37 & .460 \\
\hline & 22.01 & 1.34 & 2.37 & .435 \\
\hline & 22.40 & 1.35 & 2.38 & .433 \\
\hline & 22.59 & 1.36 & 2.39 & .431 \\
\hline & 23.32 & 1.31 & 2.38 & .450 \\
\hline & 29.11 & 1.01 & 2.44 & .586 \\
\hline & 29.93 & 1.22 & 2.42 & .496 \\
\hline \multirow[t]{5}{*}{ USW UZ-N24 } & 8.08 & 1.94 & 2.49 & .221 \\
\hline & 8.72 & 1.64 & 2.55 & .357 \\
\hline & 8.99 & 1.56 & 2.50 & .376 \\
\hline & 9.30 & 1.45 & 2.52 & .425 \\
\hline & 9.75 & 1.54 & 2.46 & .374 \\
\hline
\end{tabular}


Table 15. Results of laboratory analyses of physical properties of rotary-core samples from selected neutron-ac-ess boreholes--Continued

\begin{tabular}{|c|c|c|c|c|}
\hline $\begin{array}{c}\text { Neutron-access borehole } \\
\text { number }\end{array}$ & $\begin{array}{c}\text { Depth } \\
\text { (meters) }\end{array}$ & $\begin{array}{l}\text { Bulk density } \\
\left(\mathrm{g} / \mathrm{cm}^{3}\right)\end{array}$ & $\begin{array}{l}\text { Grain density } \\
\left(\mathrm{g}^{\prime} \mathrm{cm}^{3}\right)\end{array}$ & $\begin{array}{l}\text { F rosity } \\
\left(\mathrm{c}^{3} / \mathrm{cm}^{3}\right)\end{array}$ \\
\hline USW & 9.88 & 1.59 & 2.49 & 0.361 \\
\hline \multirow[t]{24}{*}{ UZ-N24--Continued } & 10.61 & 1.70 & 2.43 & .300 \\
\hline & 10.82 & 1.72 & 2.43 & .292 \\
\hline & 11.49 & 1.71 & 2.42 & .293 \\
\hline & 11.73 & 1.70 & 2.42 & .298 \\
\hline & 12.19 & 1.71 & 2.44 & .299 \\
\hline & 13.66 & 1.61 & 2.43 & .337 \\
\hline & 13.72 & 1.57 & 2.43 & .354 \\
\hline & 14.72 & 1.42 & 2.51 & .434 \\
\hline & 15.58 & 1.27 & 2.50 & .492 \\
\hline & 15.91 & 1.24 & 2.50 & .504 \\
\hline & 16.86 & 1.25 & 2.48 & .496 \\
\hline & 17.37 & 1.29 & 2.49 & .482 \\
\hline & 17.83 & 1.30 & 2.50 & .480 \\
\hline & 18.17 & 1.34 & 2.47 & .457 \\
\hline & 18.29 & 1.36 & 2.46 & .447 \\
\hline & 19.05 & 1.35 & 2.45 & .449 \\
\hline & 19.51 & 1.32 & 2.38 & .445 \\
\hline & 20.12 & 1.16 & 2.39 & .515 \\
\hline & 20.82 & 0.96 & 2.42 & .603 \\
\hline & 21.21 & .99 & 2.43 & .593 \\
\hline & 21.58 & 1.32 & 2.43 & .457 \\
\hline & 21.82 & 1.34 & 2.39 & .439 \\
\hline & 22.16 & 1.28 & 2.38 & .462 \\
\hline & 22.68 & 1.33 & 2.42 & .450 \\
\hline \multirow[t]{17}{*}{ USW UZ-N46 } & 0.12 & 1.18 & 2.39 & .506 \\
\hline & .94 & 1.22 & 2.44 & .500 \\
\hline & 1.52 & 1.34 & 2.46 & .455 \\
\hline & 2.87 & 1.51 & 2.46 & .386 \\
\hline & 3.57 & 1.59 & 2.48 & .359 \\
\hline & 4.11 & 1.65 & 2.45 & .327 \\
\hline & 4.57 & 1.64 & 2.46 & .333 \\
\hline & 5.36 & 1.63 & 2.48 & .343 \\
\hline & 6.10 & 1.78 & 2.48 & .282 \\
\hline & 7.16 & 1.77 & 2.47 & .283 \\
\hline & 7.99 & 1.81 & 2.48 & .270 \\
\hline & 8.66 & 1.84 & 2.48 & .258 \\
\hline & 9.14 & 1.83 & 2.47 & .259 \\
\hline & 9.81 & 1.87 & 2.49 & .249 \\
\hline & 10.67 & 1.91 & 2.50 & .236 \\
\hline & 11.58 & 2.06 & 2.48 & .169 \\
\hline & 12.25 & 2.01 & 2.50 & .196 \\
\hline
\end{tabular}


Table 15. Results of laboratory analyses of physical properties of rotary-core samples from selected neutron-access boreholes--Continued

\begin{tabular}{|c|c|c|c|c|}
\hline $\begin{array}{c}\text { Neutron-access borehole } \\
\text { number }\end{array}$ & $\begin{array}{c}\text { Depth } \\
\text { (meters) }\end{array}$ & $\begin{array}{l}\text { Bulk density } \\
\left(g / \mathrm{cm}^{3}\right)\end{array}$ & $\begin{array}{l}\text { Graln density } \\
\left(\mathrm{g} / \mathrm{cm}^{3}\right)\end{array}$ & $\begin{array}{l}\text { Porosity } \\
\left(\mathrm{cm}^{3} / \mathrm{cm}^{3}\right)\end{array}$ \\
\hline USW & 13.93 & 2.01 & 2.51 & 0.199 \\
\hline \multirow[t]{19}{*}{ UZ-N46--Continued } & 15.15 & 2.06 & 2.51 & .179 \\
\hline & 15.48 & 2.03 & 2.46 & .175 \\
\hline & 16.25 & 2.03 & 2.51 & .191 \\
\hline & 16.98 & 2.02 & 2.49 & .189 \\
\hline & 17.56 & 2.12 & 2.49 & .149 \\
\hline & 23.47 & 1.50 & 2.48 & .395 \\
\hline & 23.71 & 1.53 & 2.51 & .390 \\
\hline & 23.99 & 1.74 & 2.43 & .284 \\
\hline & 24.32 & 1.60 & 2.48 & .355 \\
\hline & 24.78 & 1.54 & 2.45 & .371 \\
\hline & 25.60 & 1.35 & 2.42 & .442 \\
\hline & 26.34 & 1.41 & 2.43 & .420 \\
\hline & 27.04 & 1.38 & 2.41 & .427 \\
\hline & 27.22 & 1.39 & 2.41 & .423 \\
\hline & 27.68 & 1.42 & 2.43 & .416 \\
\hline & 28.53 & 1.48 & 2.39 & .381 \\
\hline & 28.77 & 1.25 & 2.42 & .483 \\
\hline & 29.32 & 1.33 & 2.43 & .453 \\
\hline & 30.05 & 1.30 & 2.41 & .461 \\
\hline \multirow[t]{16}{*}{ USW UZ-N47 } & 10.67 & 1.97 & 2.49 & .209 \\
\hline & 11.70 & 2.05 & 2.48 & .173 \\
\hline & 12.16 & 2.06 & 2.50 & .176 \\
\hline & 16.83 & 2.12 & 2.48 & .145 \\
\hline & 17.25 & 2.11 & 2.49 & .153 \\
\hline & 21.46 & 1.51 & 2.55 & .408 \\
\hline & 21.64 & 1.53 & 2.47 & .381 \\
\hline & 22.74 & 1.34 & 2.47 & .457 \\
\hline & 23.10 & 1.44 & 2.46 & .415 \\
\hline & 23.56 & 1.41 & 2.41 & .415 \\
\hline & 23.68 & 1.40 & 2.44 & .426 \\
\hline & 24.32 & 1.41 & 2.43 & .420 \\
\hline & 24.66 & 1.30 & 2.42 & .463 \\
\hline & 25.02 & 1.42 & 2.41 & .411 \\
\hline & 25.51 & 1.47 & 2.43 & .395 \\
\hline & 26.06 & 1.31 & 2.48 & .472 \\
\hline \multirow[t]{5}{*}{ USW UZ-N98 } & 7.92 & 1.97 & 2.52 & .218 \\
\hline & 8.69 & 1.13 & 2.52 & .552 \\
\hline & 9.45 & 1.39 & 2.53 & .451 \\
\hline & 10.36 & 1.39 & 2.53 & .451 \\
\hline & 11.25 & 1.54 & 2.51 & .386 \\
\hline
\end{tabular}


Table 15. Results of laboratory analyses of physical properties of rotary-core samples from selected neutron-ac:ess boreholes--Continued

\begin{tabular}{lcccc}
\hline $\begin{array}{c}\text { Neutron-access borehole } \\
\text { number }\end{array}$ & $\begin{array}{c}\text { Depth } \\
(\text { meters })\end{array}$ & $\begin{array}{c}\text { Bulk density } \\
\left(\mathbf{g} / \mathbf{c m}^{3}\right)\end{array}$ & $\begin{array}{c}\text { Graln density } \\
\left(\mathbf{g} / \mathbf{c m}^{3}\right)\end{array}$ & $\begin{array}{c}\text { Pnrosity } \\
\left(\mathbf{c ~ m}^{3} / \mathbf{c m}^{3}\right)\end{array}$ \\
\hline USW & 11.70 & 1.57 & 2.48 & 0.367 \\
UZ-N98--Continued & 12.13 & 1.55 & 2.46 & .370 \\
& 12.62 & 1.53 & 2.47 & .381 \\
& 13.44 & 1.43 & 2.53 & .435 \\
& 13.72 & 1.38 & 2.56 & .461 \\
& 14.51 & 1.45 & 2.49 & .418 \\
& 15.24 & 1.42 & 2.45 & .420 \\
& 16.70 & 1.25 & 2.46 & .492 \\
& 16.76 & 1.26 & 2.48 & .492 \\
& 17.37 & 1.24 & 2.51 & .506 \\
& 17.74 & 1.27 & 2.50 & .492 \\
& 18.23 & 1.30 & 2.46 & .472 \\
& 18.53 & 1.34 & 2.46 & .455 \\
& 19.02 & 1.29 & 2.46 & .476 \\
& 19.57 & 1.32 & 2.44 & .459 \\
& 20.06 & 1.20 & 2.51 & .522 \\
& 20.45 & 0.94 & .634 \\
& 20.97 & .99 & 2.57 & .594 \\
& 21.24 & 1.28 & 2.44 & .473 \\
& 21.55 & 1.30 & .463 \\
\end{tabular}

Table 16. Description of central tendency and dispersion of density and porosity data as a function of lithology ant degree of welding

\begin{tabular}{|c|c|c|c|c|c|c|c|c|c|c|}
\hline \multirow[b]{2}{*}{ Lithologlc unit } & \multirow{2}{*}{$\begin{array}{l}\text { Degree of } \\
\text { welding }\end{array}$} & \multirow{2}{*}{$\begin{array}{l}\text { Num- } \\
\text { ber of } \\
\text { sam- } \\
\text { ples }\end{array}$} & \multicolumn{4}{|c|}{$\begin{array}{l}\text { Bulk density } \\
\text { (grams per cublc centlmeter) }\end{array}$} & \multicolumn{4}{|c|}{$\begin{array}{l}\text { Porosity } \\
\text { (cubic centlmeter per cubie centImeter) }\end{array}$} \\
\hline & & & Data range & Mean & $\begin{array}{l}\text { Standard } \\
\text { devl- } \\
\text { atlon }\end{array}$ & Medlan & Data range & Mean & $\begin{array}{c}\text { Standard } \\
\text { devl- } \\
\text { ation }\end{array}$ & Median \\
\hline $\begin{array}{l}\text { Paintbrush Tuff } \\
\text { Bedded Tuff }\end{array}$ & Nonwelded & 31 & 0.94 to 1.48 & 1.258 & 0.141 & 1.300 & 0.381 to 0.634 & 0.484 & 0.060 & 0.472 \\
\hline $\begin{array}{l}\text { Tiva Canyon } \\
\text { Member }\end{array}$ & $\begin{array}{l}\text { Nonwelded to } \\
\text { partially }\end{array}$ & 27 & 1.24 to 1.72 & 1.426 & .164 & 1.420 & .292 to .506 & .420 & .071 & .435 \\
\hline $\begin{array}{l}\text { Tiva Canyon } \\
\text { Member }\end{array}$ & Moderately & 11 & 1.39 to 1.70 & 1.538 & .096 & 1.550 & .300 to .451 & .383 & .044 & .374 \\
\hline $\begin{array}{l}\text { Yucca Mountain } \\
\text { Member }\end{array}$ & $\begin{array}{l}\text { Nonwelded to } \\
\text { partially }\end{array}$ & 57 & 1.18 to 1.84 & 1.460 & .153 & 1.420 & .258 to .506 & .398 & .058 & .412 \\
\hline $\begin{array}{l}\text { YuccaMountain } \\
\text { Member }\end{array}$ & Moderately & 16 & 1.83 to 2.12 & 2.016 & .085 & 2.030 & .145 to .259 & .190 & .034 & .189 \\
\hline
\end{tabular}


Table 17. Results of laboratory analyses of tritium in drive-core samples from selected neutron-access boreholes

\begin{tabular}{cccccc}
\hline \multirow{2}{*}{$\begin{array}{c}\text { Neutron-access } \\
\text { borehole number }\end{array}$} & $\begin{array}{c}\text { Depth interval } \\
\text { (meters) }\end{array}$ & Decay date & (Tritium units) & $\begin{array}{c}\text { Tritium } \\
\text { (Plcocurles per } \\
\text { ilter) }\end{array}$ & $\begin{array}{c}\text { Extracted water } \\
\text { (grams per gram) }\end{array}$ \\
\hline UE-25 UZN \#1 & $2.12-2.36$ & $10-10-84$ & $18.2 \pm 0.8$ & $58.1 \pm 2.4$ & 0.055 \\
& $4.88-5.49$ & $10-10-84$ & $17.7 \pm 0.7$ & $56.5 \pm 2.4$ & .102 \\
& $6.40-6.71$ & $10-10-84$ & $18.8 \pm 0.8$ & $60.0 \pm 2.7$ & .080 \\
& $7.92-8.08$ & $10-10-84$ & $20.0 \pm 0.8$ & $63.9 \pm 2.5$ & .066 \\
UE-25 UNZ \#8 & & & & & .087 \\
& $3.05-3.66$ & $7-18-84$ & $31.3 \pm 1.2$ & $99.9 \pm 3.7$ & .081 \\
& $4.57-5.18$ & $7-18-84$ & $26.9 \pm 1.0$ & $86.0 \pm 3.3$ & .073 \\
& $6.10-6.71$ & $7-18-84$ & $18.5 \pm .8$ & $59.1 \pm 2.5$ & .066 \\
& $7.62-8.23$ & $7-18-84$ & $8.8 \pm 0.5$ & $28.1 \pm 1.7$ & .074 \\
& $9.14-9.75$ & $7-18-84$ & $2.8 \pm 0.4$ & $9.1 \pm 1.4$ & .069 \\
& $10.67-11.28$ & $7-18-84$ & $2.8 \pm 0.4$ & $9.0 \pm 1.3$ & .048 \\
UE-25 UZN \#13 & & & & & \\
& $1.52-2.13$ & $7-18-84$ & $22.3 \pm 1.0$ & $71.1 \pm 3.1$ & .045 \\
& & & & & .072 \\
& $0.61-1.22$ & $12-17-84$ & $15.4 \pm 0.7$ & $49.1 \pm 2.2$ & .097 \\
& $2.21-2.36$ & $12-17-84$ & $12.4 \pm 0.6$ & $39.4 \pm 1.9$ & .086 \\
& $3.73-3.88$ & $12-17-84$ & $7.8 \pm 0.5$ & $24.8 \pm 1.5$ & .097 \\
& $5.26-5.41$ & $12-17-84$ & $5.9 \pm 0.4$ & $18.9 \pm 1.4$ & .092 \\
\hline
\end{tabular}




\title{
United States Department of the Interior
}

\author{
U. S. GEOLOGICAL SURVEY \\ Box 25046 M.S. 421 \\ Denver Federal Center \\ Denver, Colorado 80225
}

WBS: 1.2.3.3.1.2.1

MEMORANDUM

Date: January 16,1998

To: Distribution

From: Becci Clayton, Reports Processing Unit, ESIP, YMPB, Denver, CO, MS 42

Re: PUBLICATIONS -- Errata sheet for Open-File Report 92-657, "Geohydrologic data colle-ted from shallow neutron-access boreholes and resultant-preliminary geohydrologic evaluations, Yucca Mountain area, Nye County, Nevada", by D.O. Blout, D.P. Hammermeister, C.L. Loskot, and M.P. Chornack

An error was made in the above listed report on page 143, Table 15, in the depth column for UE-25 UZN \#10: depth 1.09 meters should be 10.09 meters.

Apologies are made for any inconvenience this may have caused. 